\title{
THE NATURE
}

AND

PIRST PRINCIPLE

$\mathrm{OF}$

TAXATION

ROBERT JONES 

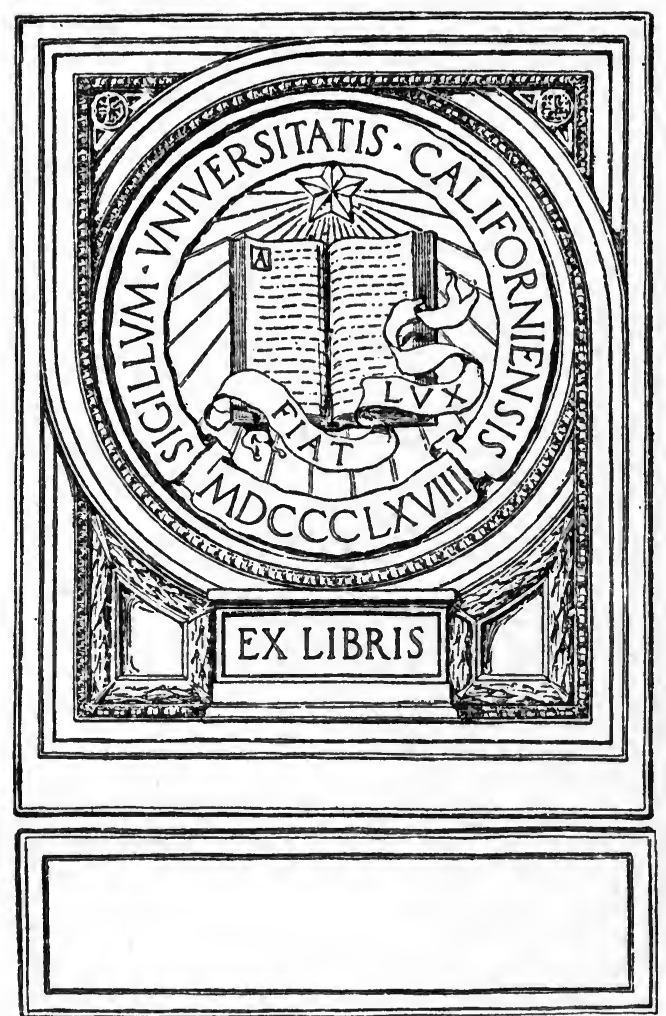


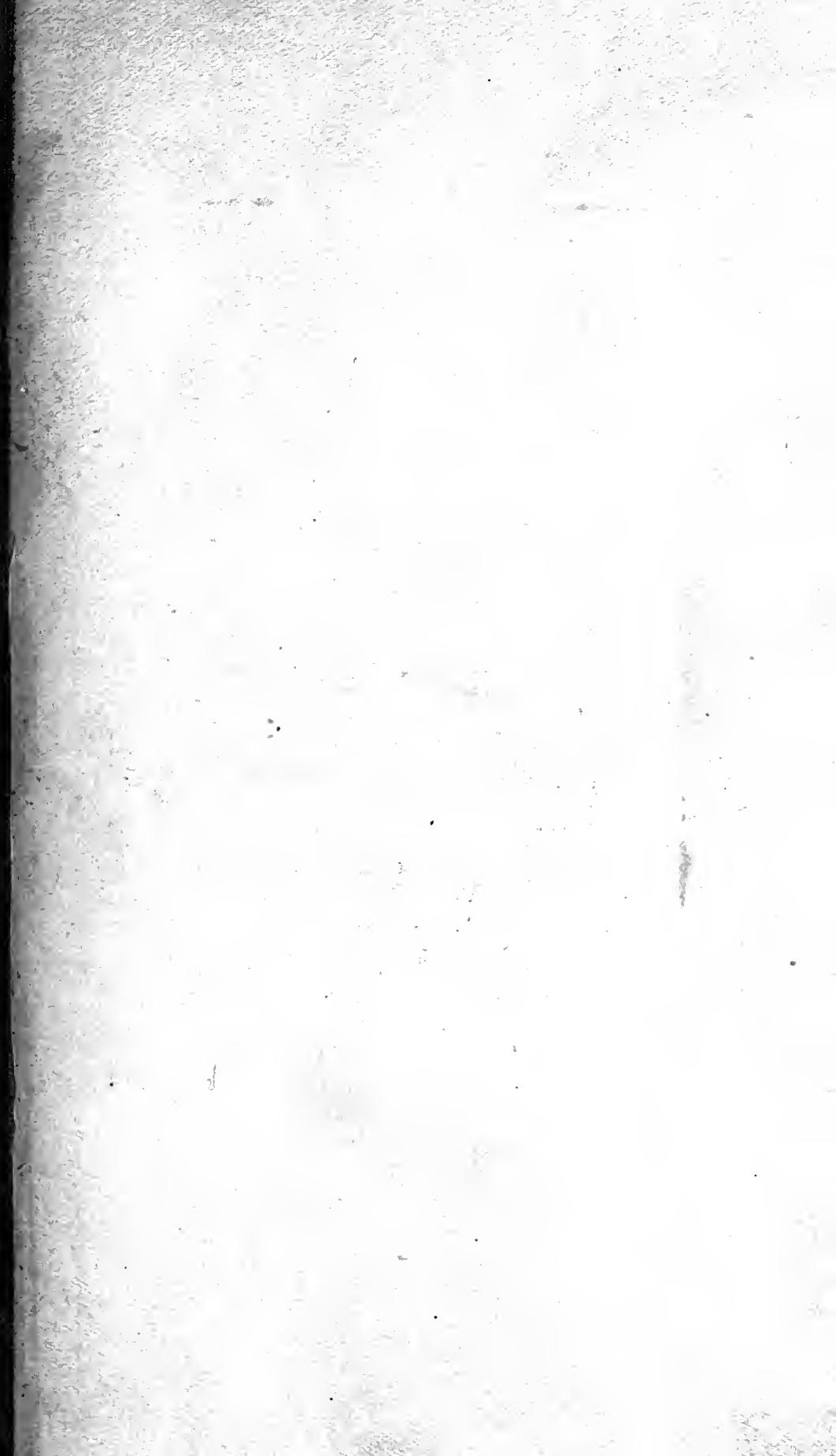


Digitized by the Internet Archive in 2007 with funding from Microsoft Corporation 



\section{STUDIES IN ECONOMICS AND POLITICAL SGIENCE}

Edited by the Hon. W. PEMBER REEVES,

Director of the London School of Economics.

No. 37 in the Series of Monographs by Writers connected with the London School of Economics and Political Science.

\section{THE NATURE AND FIRST PRINCIPLE}

OF TAXATION 



\section{THE NATURE AND}

FIRST PRINCIPLE

OF TAXATION

BY

ROBERT JONES

B.Sc.(Econ.)

WITH A PREFACE BY

SIDNEY WEBB, LL.B.

LONDON

P. S. KING \& SON

ORCHARD HOUSE

WEST M I N T ER 


$$
\begin{aligned}
& H^{5} 2^{305} \\
& .56
\end{aligned}
$$

efor. 


\section{AUTHOR'S INTRODUCTION.}

The writer is indebted to Professor Edwin Cannan for many suggestions and criticisms, mainly embodied here as improvements upon the original plan. The term "quasi-taxes," as used in this book, was one such suggestion : the phrase originally used was " mixed taxes."

Taxation is a subject not usually associated with the lighter or more cheerful thoughts of men. Bright exceptions there are, such as Sydney Smith's lively description of the career of the schoolboy who "whips his taxed top," who rides, as a youth, on a taxed horse with a taxed bridle along a taxed road, who dies at last, in a bed taxed 22 per cent., after taking his last drop of medicine, taxed 7 per cent., in a spoon that has paid I5 per cent.; " his virtues are handed down to posterity upon taxed marble; and he is then gathered to his fathers,to be taxed no more." The jest is somewhat grim. There is a lighter touch in a Bluebook upon Taxation, to be cited as C. 9528, I899, where I find on page I7I the following answer to the question as to what would be the effects of excusing tenants from paying their rates.

"I2. If occupiers were allowed to deduct either rates, or the cost of getting their hair cut, or any 
other expense, from their rents, then their rents would be that much higher. If they were not allowed to deduct the income tax their rents would be that much lower."

But such admixtures of wit and wisdom are very rare in the literature of taxation, and if their mention here, and the allusion to Professor Cannan (who first brought to the Dismal Science the saving human grace of humour) arouses a hope in any reader that the new humour of the new economists will be represented in this book, I can but sympathise with his disappointment, and look forward, with him, to the time when the laws of economics and of taxation will be too surely based for their clerics to fear or suspect the effects of any shock that might come from the waves of even the heartiest laughter. Meanwhile, there is spadework to be done, and most of it is somewhat dull in the doing and in the telling.

A dignitary of the Church has told us, quite recently, that he finds the payment of his income tax an exhilarating duty; and that is a splendid lesson in citizenship. Chancellors of the Exchequer also, no doubt, find in the payment of income tax (and of other taxes) a healthy and inspiring proof of national life ; and our neighbours across Channel have attempted to define taxation as an expression of national solidarity. So that, even from the taxpayer's point of view, it seems as if the subject is not necessarily doomed to be for ever divorced from cheerfulness. I offer these faint portents of 
hope to the reader who nods over this volume. His grandson, perhaps, will open a new volume on Taxation with a smile. We cannot assess the value of a possible grandson's possible smile: but hope is one of the foods of life, not one of its soporifics.

The arrangement of this work makes it possible for the reader to make himself acquainted with its contents in whatever degree of completeness his leisure, energy or inclination suggests, by turning to-
(a) The Summary ;
(b) The general argument as given in Chapters I and III.

(c) The case with its limitations given in Chapters I, III, IV.

(d) The whole statement of the four chapters, with the use of the brief summaries of the sections of Chapter II, and such of the quotations in that chapter as arouse any individual interest.

The Appendix to Chapter I is rather for reference than for reading. It forms the raw material of the argument elaborated in that Chapter.

The Appendix on Family Budgets in relation to Taxes is not intrinsically a part of the thesis of the book, but it touches upon the whole of the problem of "Incidence" (a word I have thought fit to avoid altogether), and it is closely bound up with what is at the back of most people's minds when the distribution of taxes is under discussion. What proportion of taxes rich people and poor 
people ought to pay, what proportion of taxes they are actually paying, are questions of tremendous practical importance. The general relation of these questions to the special object of this work, and their significance in national life, are ample justification for so much of a wandering from the question at issue as this Appendix represents.

The quotations given are from the original sources, except where (as stated) a standard translation has been used; and in these cases the original also has been consulted. The translations from French, German, Italian, Latin and Greek works have been made direct from the originals, but quotations from books in Asiatic languages are given from translations already issued.

There are likely to be some errors, and there are certain to be serious omissions, in a work of this kind, and the writer will be grateful to any one who calls his attention to errors or omissions. ROBERT JONES.

London School of Economics, W.C. November, I9I3. 


\section{TABLE OF CONTENTS.}

CHAP.

AUthor's InTRODUCTION • • • • $\quad$ - v

Preface, by Sidney Webb . . . . xiii

I. The Nature of a TAX • • • • • I

Plan of the Relation of Taxes to Revenue in General . $2 \mathrm{I}$

Diagrammatic View of Taxes and Prices • • $4 \mathrm{I}$

II. The Development of Ideas about Taxation . $\quad 45$

§ I. Early Notions • • • • • • • 47

Introductory Note- (a) References in Ancient Sacred

Books :- Biblical References - Âpastamba -

Vasistha-Laws of Manu-Lî Kî-(b) Ancient

Greece and Rome :- Herodotus - Pseudo-

Xenophon-Plato - Cicero - Livy - Dionysius

Halicarnassus-Pliny-Tacitus-Pollux.

§ 2. The Blank Period . . . . 56

Introductory Note-Codex Justinianus-K'ung Yingta-Lu Chih.

§ 3. The Formative Period. • . • .

La Mothe - Hobbes-Harington - Petty -

Pufendorf - Locke - Boisguillebert-Vauban-

Decker-Hume-Montesquieu-Justi.

$\S$ 4. The Physiocratic Period . . 74

Introductory Note-Quesnay - Rousseau - Bielfeld

- Mirabeau - Pesselier-Adam Smith (I) -

Turgot-La Rivière-Dupont de Nemours-Sir

James Steuart-Editors of Voltaire-Moreau de

Beaumont-Isaac Pinto-Verri-Lord Kames

(Henry Home)-A. Young. 
CHAP.

§ 5. Adam Smith to Ricardo . . . $\quad$. 96

Introductory Note-Adam Smith (2)-Burke-Necker -Gale-Jeremy Bentham - "The Declaration of the Rights of Man "-Adam Ferguson-Condorcet-Macnab-J. B. Say-Dugald StewartDavid Buchanan.

§ 6. Ricardo to Mill . $\quad$. $\quad$. $\quad$. $\quad$. $\quad$. 109

Introductory Note-David Ricardo-SismondiJames Mill-Channing-Sir :Henry ParnellChalmers-Anonymous-Senior-Rau-Scialoja -Torrens-McCulloch.

§ 7. Mill to Jevons . . . . . Introductory Note-J. S. Mill-Thiers-J. S. Buckingham-Walras-De Parieu-Sargant-Thorold Rogers.

§ 8. Jevons to Sidgwick . . . . .

Introductory Note-Jevons - Baxter-Held - Berthelot-Cliffe Leslie-Menier-Henry George -Henry Sidgwick.

§ 9. The Moderns

Introductory Note-Wagner-Stein-Herbert Spencer-Colson-Stourm-Ross-Cohn-Schäffle Walker-Hadley-Wells-Edgeworth - ReidPierson-Cannan-Nitti-Conrad - Eheberg Bastable-Boucard et Jèze-Carver-LeroyBoileau-Armitage Smith-Fetter-J. A. Hobson-H. C. Adams-Wicksteed-AltmannChapman-Taussig-J. Orr.

III. The First Principle of TAXation

Diagram, Diminishing Utility of Increments of Income.

Diagrams of Progressive Scales . . . 188 I9I

Table of the English Death Duties $\cdot{ }_{\text {Proportional, Progressive, and Procrustean Scales }}$ of Taxes

Tables showing the increasing Proportion of Taxes paid directly out of Income . . . . 
CHAP.

PAGE

IV. The Limitations and the Complements of the PRINCIPLE OF ECONOMY in TAXation • . 213 Diagram : Taxes and Public Advantage . $\quad 232$

SUMMARY

Appendix to Chapter I.-

A Collection of Definitions . . . . . . 246 $\S$ I. A list of terms, English, French, German, Italian 247

$\S$ 2. "Tax," "Taxation" . . . . . . . 248

$\S$ 3. "Fee," "Revenue," "Rate" . . . . 256

§ 4. "Impôt" . . . . . . . . . . 259

§ 5. "Steuer". . . . . . . . . 264

$\S 6$. A few other terms, with a note on incorrect definitions .

A Note on Family Budgets and Taxes . • • • 270 Bibliographia

Part I. General

Part II. Current $\quad . \quad$. $\quad . \quad$. $\quad . \quad 289$

INDEX 



\section{PREFACE.}

Whether this book will reconcile any taxpayer to the burden laid upon him by the Chancellor of the Exchequer must remain obscure. There are some people, it may be suspected, who would rather pay taxes than read about them! But to all who seek to understand the How and Why of taxation, it will be of the greatest use. Those who have written about taxes are almost as numerous as the taxes themselves; and in collecting and comparing these diverse opinions and definitions, Mr. Jones has done us all a valuable service. His skilful analysis of the real nature of taxation, and of the necessary limitations of each of the celebrated "axioms" by which successive Finance Ministers have pretended to be guided, amounts to an advance in the science.

When an economist thinks about taxation he cannot get away from the notion of compulsorily levying revenue for the purposes of Government. That, as Mr. Jones shows, is essentially the meaning -we may say the hateful meaning-of the term, in history, literature and law, as well as in the usage of Treasury Clerks and "bold, bad" Chancellors.

If they have to pick our pockets, how best can it be done? Along this line Mr. Jones conducts $x$ iii 
us skilfully enough to the practical ideal of a steeply graduated income tax, which shall discreetly stop short of being "Procrustean." I.t was not part of Mr. Jones's thesis to explore what might perhaps be called the "subliminal self" of taxation, though he gives us some hints!

The irresponsible preface-writer is puckishly impelled to inquire, What would happen to the Budget of the United Kingdom if the thousand richest millionaires of the world, "worth" in the aggregate perhaps two hundred and fifty millions a year, suddenly presented all their wealth to the Chancellor of the Exchequer, as eccentric testators of small sums occasionally do; and if the annual income thus transferred proved just sufficient to defray the present total cost of national and local administration? We could then afford to abolish, in one wild night of joyous revolution, all our rates and taxes. Should we do so? The question is worth pondering over. Some people would recall what happened when gin was untaxed, and there might be drawbacks to universally untaxed dogs and unlicensed guns. Moreover, why because the nation had collectively become richer, should it bestow largess on an arbitrarily selected minority of individual property owners by letting them off tithe and land-tax?

If the community took time to think the matter out, and managed, somehow, to escape the influence of these property owners, it is conceivable that it might find that there were very few taxes worth abolishing, even if their revenue were not required 
to enable our Governments to pay their way. It is time that some one made a stand for the positive advantages of taxations. In sober truth, there are in the United Kingdom of to-day not a few taxes that we could not afford to lose, even if we did not need the revenue.

It is time, too, that we emphasized the fact that a large part of what we call taxation is merely the collective ownership of a portion of the income of the country. The Government, it has been well said, is not only a co-owner with every individual landlord, but also a sleeping partner in every business enterprise. When we remember that the total amount raised by national and local taxation in I9I3 is really little more per head of population than was being raised in I8I3, although the product per head, and rent and profits, have, in the aggregate, enormously increased, we may be tempted to ask, Why has the Chancellor of the Exchequer allowed the community to be "done" out of its legitimate share of this increment? There is certainly no reason why any part of the share that the nation still receives should ever be alienated for individual private advantage.

Yet another consideration has to be borne in mind before we can dismiss the subject. The economists have analysed the effect of taxation in diminishing individual incomes; and they are led, as Mr. Jones well shows, to the conclusion that taxes should skim off everywhere the "least useful" portions of those incomes. An analysis of no less 
significance might be made into the effect upon the nation's expenditure of wisely adjusted taxation. Ought we not by taxation to cut off the least useful part of the national expenditure? For whether our object be the greatest material wealth, or the most perfect life, it matters to us a great deal whether much or little of the national income is spent in ways which make us healthier, and wiser, and wealthier; or whether it is spent in ways which make us less healthy, less wise, and less wealthy. Now how does the matter stand in this respect between the two and fifty millions sterling that we spend each year collectively, and the eighteen hundred millions sterling, or thereabouts, that we spend each year individually? The economists told us, years ago, that, of the then aggregate of private incomes, at least five hundred millions a year is spent in ways that we can in no sense justify-in riotous living that impairs our health, in foolish extravagancies that actually lessen our aggregate enjoyment, in a consumption of so-called luxuries that, far from increasing our capacity, make us at once less wealthy, less healthy, and less wise. This is rather a scathing indictment. Of the incomes of which we are allowed the individual spending, we waste (or worse than waste) something like a third. Inefficient and wasteful as our Governments may be, no such indictment can be brought against that portion of the national income of which they retain the spending. Government expenditure is; in fact, far more wisely done (on any view of wisdom) than 
the average of private expenditure. There is no getting away from the inference that a progressive transfer of more and more of the national income from individual to collective channels, would result in a positive improvement in the character of the nation's total expenditure. By improvement is meant that a larger proportion of the national income would then be devoted to purposes of permanent utility, as distinguished from momentary enjoyment; a larger proportion would be given to needs that are primary, as compared with needs that are secondary; a larger proportion would be allocated to the maintenance of health, and a smaller proportion to indulgences destructive of health; a larger proportion would be laid out on the children, and a smaller proportion on the adults; a larger proportion would be appropriated to things of the mind, and a smaller proportion to things of the body. We ought to think of this, when we are invited by abolishing taxes to transfer some of our collective income to individual pockets.

There are other beneficences of taxation, but I ought not to seem to implicate $\mathrm{Mr}$. Jones in such unconventional opinions. Yet a volume about taxes must not be allowed to treat them as being wholly evil!

SIDNEY WEBB.

4I, Grosvenor RoAd, Westminster, November, I9I3. 



\title{
The Nature and First Principle of Taxation
}

\author{
CHAPTER I. \\ The Nature of a Tax.
}

I.

TAXATION is a part of public revenue, which in turn is a part of public finance. The whole theory of public finance should then include a theory of expenditure, a theory of the relations between revenue and expenditure, and a theory of revenue. This last at least would contain more than one theory, corresponding to such different parts of revenue as were on different bases; and one of the most important would be a theory of taxation.

No objective theory of expenditure has yet appeared. Such subjective theories as have been framed drive back to the doctrines of greatest present and greatest future benefits. This offers a goal rather than a path, and is as applicable to questions of collecting as to questions of spending. More progress has been made with the theory of expenditure, just as in economics, the theory of production is farther advanced than the theory of consumption.

There are clear lines of distinction between certain sources of revenue, and one source, taxation, can be separated out as a definite thing, though not generally expressible, in every concrete case, in a definite sum. For although it is possible to distinguish between what is taxation and what is not, it is impossible to say how much of the revenue of the 
British Government, or of the London County Council, represents a real tax. Of certain items, such as the proceeds of the Income Tax, it is possible to say that they represent taxes in the strictest sense, and no more. Of others, such as the profits from municipal tramways, we may say that they contain no element of taxation. But there are many payments made to governing bodies of which a portion may be strictly comparable with payments made by a purchaser in a shop, whilst another portion is truly and exclusively a tax. It is not essential to a correct theory that we should be able to say how much of a given sum of this kind is to be written down as a tax. What is essential is that we should have some satisfactory test enabling us to detect the presence or absence of the taxelement, as chemical reagents enable the physicist to detect the presence or absence of copper or iron. If a quantitative analysis can be added to the qualitative analysis, so much the better.

If, then, taxation is indeed a distinct and separable part of public revenue, as common speech and common usage suggest, it must have some distinctive qualities by which it can always be traced and recognised. Whether it be found pure and unmixed, or combined with other elements, it should be possible, once its essential characteristics are known, to detect its presence, and, however incompletely, to assess its amount. And when, as now happens, human societies show a tendency towards increased public revenues, different groups and classes of men are naturally driven to inquire how far the system of taxation under which they live is in accordance at once with the just claims and duties of their group or class, and with the proper needs of the community. The canons of justice by which they will measure their obligations will be those of the age and of the community in which they live, coloured and modified by the thought and feeling of their class, and of their own individual convictions. Yet there is always, in these assessments of justice, some sort of a Court of Appeal-in this case the findings of economic and political science.

It is essential, at the outset, that we should know, as 
infallibly as may be, what exactly taxation is, and thus (what is often of more immediate import) what it is not. This is but to insist on an accurate definition.

We have now two branches of inquiry indicated: the relation of taxation to the general subject of public finance, and the criteria of a true tax. As each of these inquiries assumes the existence of taxation as a distinct and definite thing, we are at liberty to take them in the order given.

Professor Bastable considers public finance under the headings Public Expenditure; Public Revenue; the Relation of Expenditure and Receipts ; Financial Administration and Control. Local and National finance are treated concurrently.

Professor Conrad makes the following divisions-The Theory of Taxes; Revenue from State Property and State Trading (Staatsbesitz und Staatsbetrieb); The Nature of Public Debts (Staatsschuldenwesen); State Expenditure and the State; Local Finance; Historical Review.

A third arrangement is shown in "Science des Finances" of MM. Boucard et Jèze,-The Budget; The State as Debtor; The State as Creditor (including Taxation); Treasury Service ; Control of the Budget.

For a fourth and last example we may take Walker's. $\mathrm{He}$ traces the revenue of the State in this manner: Voluntary Contributions; Lucrative Prerogatives; Public Property, and State Enterprise; Quasi-Taxes (which is subdivided into Monopolies, Lotteries, Purveyance, Fees, Seigniorage upon the coin, The Issue of Paper Money), and lastly, Taxation in its various forms.

These examples are sufficient to show how wide are the possible divergencies of treatment. One plan is centred round administrative custom, another begins with a theory and ends with a history, a third is built about the Budget. But we are only concerned, for the purposes of this inquiry, with noting the place that taxation takes in relation to public finance, and for this the simplest method of classification is as useful as any other. We can divide public finance into its two branches, Revenue and Expenditure, leaving the question of the relations of the two parts to each other, 
and the administration of each to be treated under the two general headings, or as introductory or complementary matter.

The inclusion of local with national finance, or their separation, is not to be decided quite so summarily, but it is a matter to be settled even more dogmatically. If it be urged that a separate consideration of local finance, and of the relations between it and national finance, is necessary in order to avoid an arrangement likely to put a dozen chapters into one paragraph, there will be general assent, quite apart from views about the district, township, or borough being " either a microcosm of the State or something opposed to it." (Ernst Meyer, quoted by Professor Conrad, Grundriss, III. I6I.)

But if it were urged that the differences between local and national finance are so vital that a separate examination is necessary because of differences in the theory of the two, just as it has been suggested that a distinct theory of international trade could be built up, having its own exclusive laws, then it is not unfair, in one case or in the other, to ask what are the differences that call for a separate theory.

No such differences have yet been pointed out. When we have satisfied ourselves as to what is and what is not taxation, we shall be able to recognise taxes under any name, whether levied by sovereign or subordinate bodies. When we know their nature, we shall be able to investigate the laws of their action, irrespective of the person or the body that imposes them.

We may now consider the parts into which revenue may be divided, in order to bring out the relation which taxes bear to the other parts, and to the whole of revenue. These parts have been arranged by various writers under such heads as Fees, Taxes, Quasi-Taxes, Rents of the Domain, Prerogative Rights, Profits of State Industry, Forced Services, Contributions, Monopoly Profits, Fines, Lotteries, Purveyance, Tributes, Rates, Assessments, Customs and Excise. The question is discussed in Professor Bastable's " Public Finance," Bk. II. Chap. i.

The method of classification depends on the purpose in 
view. There is no one system that is best for all inquiries, economic, administrative, political. On a preliminary examination of the items given above, there appear some that can be grouped together, perhaps at first quite roughly: Rents of the Domain, Monopoly Profits, Profits of State Industry, Lotteries (Fees). In the first three, and somewhat less clearly in the case of Lotteries and Fees, the payments are made in return for something offered-the use of land or goods, the chance of a big prize, the service of a legal or other department. The word "profits" would cover this group fairly well.

A second group may be formed thus,-

Forced Services, Taxes, Fines, Prerogative Rights, (Customs, Excise) (Purveyance).

Here a general characteristic of compulsion appears and the distinguishing mark of the first group, payment for something offered in return, is missing. Since these two groups include the majority of the terms that have been used to indicate the subdivisions of revenue, we have here a suggestion of a simple grouping into two main divisions, which we may call for the present, (I) profits and (2) forced payments or services.

Among the few items that are omitted from both groups, there is one that is significant because of its importancerates. If we had in mind, when forming the first group, a citizen paying his water-rate, we should have been inclined to consider that payment as "a payment for something offered in return" (in this case, a supply of water), and we should certainly have included " rates" in this group. Had we been thinking, however, of a wealthy bachelor citizen paying his education rate, we should as certainly have put "rates" in the other group, for we cannot here recognise any " payment for something in return."

This suggests a group midway between the two we have formed. So far, then, we have these groups-

(a) Forced Payments or Services, of which "taxes" are the chief item.

(b) Profits, Rents, and Fees, which may be grouped broadly under " Profits." 
(c) Cases between (a) and (b).

(d) The doubtful or remaining items, i.e. Quasi-Taxes, Borrowings, Tributes.

We may deal first with the third group. If it is possible to trace a rate or similar charge, and to fix it definitely as a payment for something offered in return, or definitely as a forced payment, then it can be classed in the first or second group. But if it cannot be put definitely in the one or the other group, the third division will be necessary. QuasiTaxes would belong to this third group, and such a name might be taken to cover the whole group, giving us-

(a) Forced Payments; or Taxes.

(b) Profits.

(c) Quasi-Taxes.

As to Borrowings and Tributes. Borrowings are certainly not to be classed with Taxes, except in the case of Forced Loans, which might reasonably be grouped with Forced Services. To revert to our former phrase, we may certainly say that loans to a government are " payments for something offered in return," i.e. a guarantee of income. This consideration ought to be decisive in allocating " Borrowings" to its proper group. But the phrase we have so far adopted to cover this group, "Profits," is hardly elastic enough to carry "Borrowings" as one of its subdivisions. For this reason we will put Borrowings and Tributes in a distinct group, only marking the relation we have just mentioned by a simple adjustment of position in the table on page $2 I$. It may fairly be questioned, however, whether loans form part of real revenue at all. Professor Cannan has called attention to the characteristic of regularity in this connection. The regular tribute of course forms part of revenue. It is a tax paid by a community as a whole. Regular confiscations are exceedingly difficult to maintain; the goose is not only forced to lay her golden eggs at an artificially accelerated rate, but is more or less quickly killed. Regular loans would form a part of revenue, but loans are rarely regular except for short periods.

We have now arrived at four kinds of revenue, of which two, here mentioned as Taxes and Profits, stand out as the 
chief and essential divisions of net revenue. The list of definitions in the Appendix to the present chapter ${ }^{1}$ should confirm this finding, if it be a sound one, and should more particularly confirm it by showing a tendency, increasing with the growth of economic science, to define taxes exactly on the line of distinction between them and profits. Mixed Taxes, or Quasi-Taxes, naturally arise when a governing body makes demands for payments, and gives something in return, but without any pretence of equivalence between individual payments and individual returns. Of these Quasi-Taxes we shall have more to say later. For the present we may set out our divisions of Revenue, as found,-

(a) Pure Taxes, in which no element appears but such as bears the essential marks of a tax.

(b) Profits, containing no element of taxation, and strictly comparable to the profits of private entrepreneurs, landowners, or companies. Such profits may be monopolistic or competitive.

(c) Quasi-Taxes, where there are tax-elements and profit elements combined in the same payment. The elements of pure taxation may be separable, or they may be so inextricably combined with profits that they can only be assessed, and sometimes very roughly.

(d) Borrowings and Tributes.

We have indicated that Borrowings are related to the Profits-group rather than to the Tax-group. Tributes should perhaps go with Mixed Taxes, for the payment of a tribute has always implied a claim to some measure of protection, but on the other hand it has generally been levied under compulsion. In a case where a nation voluntarily sent tribute to another, paying what was generally considered a fair market price for the amount of protection given, the transaction would go under profits. Where the tribute was forced, and where there was no guarantee of any definite amount of protection, it would be a tax. In most cases, there would be great difficulty in describing the tribute as being wholly one or the other, which leads us to

${ }^{1}$ See p. 246 et seq. 
class it with Quasi-Taxes, much as we have classed Borrowings with Profits. We may represent the difficulty, and the step we take towards solution, by the arrangement that appears in the table referred to (p. 2I), where Tributes appears twice, in these connections-
$f(a)$ Pure Taxes.
$\left\{\left(a^{1}\right)\right.$ Tributes.
$f(a b)$ Quasi Taxes.
$\left\{\left(a b^{1}\right)\right.$ Tributes.

\section{II.}

And now we may turn our attention to the two great sources of revenue, taxes and profits, leaving mixtures of these alone for the present, taking it that we have fixed the relation of taxes to revenue, and turning to consider the relation of taxes to the other great element in revenue, profits. We have said that an examination of the nature of taxation should bring to light exactly those characteristics in which it differs from profits, and that it is just here (if our classification be sound) that we should find the distinguishing marks of a true tax. In the light of this assumption, we may now examine some of the definitions of a tax that have been offered. If we take a sufficiently large number, we are likely to have before us all the essential elements, with many that are unessential. These elements, by the terms of our classification, must distinguish taxes from profits. But they must also, for the same reason, include one or more elements common to taxes and to profits-such as are sufficient to bring them equally under the description of public revenue. And for this we shall need to make some definition of profits.

As parallel to this method of inquiry, and together with it, a consideration of the history of the word " tax " and of some of its foreign equivalents, should be useful in suggesting the thing on which men's minds were fixed when they gave and kept a name for the thing.

It is quite thinkable, of course, that these two paths might prove to be not parallel at all, but divergent, leading to solutions radically different. If it were so, then the result 
of the second rather than of the first inquiry should be preferred. For all special or individual definitions are derived from common use, are dependent on it, and change with it. If a writer says he will always use the word " tax " to represent the whole income of a governing body, he may have excellent reasons for thus asking his readers to make a mental effort every time the word " tax" occurs in his book, but he is not giving a definition of what a tax is, though he may quite possibly be expressing his idea of what the word " tax" ought to mean.

It is a necessity of scientific inquiry that names should be definite, and the economist has been forced to complain, from the beginning of economic studies, that the terms he must use are taken from the common speech, and are inexact. " Rent," "tax," " profits," have all the fluidity of the spoken tongue to which they belong. In this difficulty, what is the economist to do? He needs some assurance that the same thing shall always be meant by the same word, and that the same word shall be readily evoked by the same thing. What are the alternatives open to him ?

First, he may abandon the use of the terms of common speech, and coin new names, as other inquirers have done in other branches. He may have his morula, blastula, gatrula, his oxides and oxalates, and speak of rentose pseudomorphs of taxa-terræ in elaborating his theory of the Indian land-tax.

Secondly, he may give to the common terms of speech that he uses, a fixed and arbitrary meaning of his own. He may not wander very far from ordinary usage, and he is very likely to be sparing of the terms he clothes afresh, both for his own sake and his readers'. A good example of a moderate and satisfactory use of this method is supplied by the list of definitions of terms (nine in all), prefixed to Mr. Hobson's "Industrial System."

Thirdly, he may use his terms without definition at all, just as he uses the prepositions and pronouns of his sentences, assuming, for example, that when he says "tax," his readers know what he means, just as they do when he says "over" or "them." 
An exclusive use of the first method might fairly be objected to as clumsy, of the second, as irritating, of the third, as unscientific. If we consider not any one writer on economics but the whole mass of economic writing, we can trace the growth of a method that is not strictly any one of these, but a blend of them, distinctive enough to be described as a separate method.

This fourth method begins by accepting the terms of common speech, and in their ordinary sense. When inquiry has revealed the existence of more than one thing under the same name, or some other confusion in the labelling of things that becomes a barrier to the exchange of ideas about them, a search is made into the essential features of the things that are described by the term. Some word or phrase can then be attached to the term, to signify that it implies the existence of these essential features. Thus, when the exact nature of rent has been traced, it is possible to speak of " economic rent," " true rent," " rent proper," " rent in the strict sense of the term," to distinguish the exacter from the looser and more general use.

A further development occurs when the essential marks are known and readily recognised by all probable readers or listeners, so that the word " rent," without any qualifying phrase, may be used to signify only what economists have come to recognise as rent. A last stage is possible, where a wide diffusion of exact knowledge makes it possible for any writer or speaker to assume that wherever he says " rent" he will be understood to mean what economists now mean.

How different this method is from the practice of other branches of scientific research may be illustrated by considering what has happened in another case where a popular and loosely-used term had to be dealt with. Let us take the word " buttercup," a term popularly applied to at least five different flowers. Botanists have not searched for the characteristic essentials of the buttercup, nor have they tried to distinguish between buttercups proper and buttercups in the wider sense. The average Englishman recognises a buttercup by its golden-yellow colour, its glossy petals, its cup-like shape; sometimes also by its indented 


\section{THE NATURE OF A TAX.}

leaf, its size, its habitat. But botanists have not looked more deeply into these questions of colour, shape, and so on, that true and false buttercups may be accurately recognised. They have abandoned the name, and have given us instead, Ranunculus acris, Ranunculus bulbosus, and so forth. The question of the "true" buttercup is to-day unsettled. The two flowers mentioned, the meadow crowfoot (Ranunculus acris), or the bulbous crowfoot (Ranunculus bulbosus), are indifferently accepted as buttercups by most of the people who pluck them; and some would extend the name to include the celandines, the goldilocks, or the corn crowfoot. Neither the botanist nor the untaught man can to-day lay his finger authoritatively on the "true buttercup." The botanist would certainly turn to the crowfoot rather than to the celandine or goldilocks, and would probably give the preference to the meadow crowfoot. But so also would the untaught man, and, which is more significant, for the same reasons: that is, both would be guided by the idea of a glossy butter-yellow cup, of about the size suggested by memories of buttercups gathered in early youth: guided also by subsidiary memories of grass knee-deep, long green flower-stalks, deep-cut foliage. The botanist has no criterion of buttercup-ness, as he has of the whole order of Ranunculaceæ. As a man, he may use the word buttercup with more than ordinary discrimination, but as a botanist he avoids it.

But the method that has grown up among economists is quite different. Among their buttercups and quasibuttercups, floating and circulating buttercups, they search for the most characteristic specimen, or for the most general and distinctive features, and arrive at a " true " or " pure" buttercup. They do not abandon the word and seek or make another: they narrow it.

This is the method adopted here. When we have traced the essential characteristics of all taxes, we shall be able to define and to recognise a "pure tax." A theory of taxation can then be formulated which will properly apply only to pure taxes. When we are dealing with revenue, we can apply our theory to that part of it which consists of 
pure taxes. Profits will be rightly investigated in the light of a theory of profits, and mixed payments must be dealt with, as best possible, by the help of both theories.

In an Appendix to this chapter ${ }^{1}$ there is given a series of definitions of "Tax" and of some allied terms. The plan of arrangement is set out at the beginning of the series, and where the argument here sustained calls for reference to the material from which it is in part drawn, it will not be found difficult to refer to the material itself. A strict method would perhaps call for the insertion of the series here-in fact, on first writing, it was set here : but the effect was clumsy, and the gain slight. Such readers as prefer an examination of these definitions at this point can quite readily make it.

The first examples of the series show the closest connection between " tax" and "task." To this chief conception the latest definitions return, emphasising the idea of compulsion, and dropping as unessential many of the notions which earlier economists had added. One of these additions is worth considering.

This, the commonest of all, is that a tax is " a price," " a payment," " a kind of indemnity," " an exchange of services," "a premium of insurance "; in short, any form of quid pro quo. If a tax is in any real sense a task, it cannot be balanced by some form of payment-protection of life and property, or what not. We should be touching here upon just what a tax is not, and that is exactly what some of the more modern definitions expressly say.

Here we have evidently some support of our division of revenue into $(a)$ taxes, which are tasks, and $(b)$ payments, which are the prices, high or low, of services offered. The offerers of the services (here the governing body) may make profits or losses on the transaction. If they make profits, these become a part of revenue.

So far then, the essential elements of a tax appear thus-

(a) It is compulsory (" a task").

(b) It is not the purchasing-price of something bought. Some economists, Professor Bastable for example, add 1 See pp. 246-269. 
a phrase not absolutely essential, to explain that taxes are paid by persons. ${ }^{1}$ So much confusion has come of talk about land or commodities "being taxed" or "paying a tax" that to say taxes are paid by persons is not, as it should be, a needless addition to the definition, and we will add this characteristic to the other two. For the dangers attendant on the use of an ill-chosen word or phrase in exact inquiries are by no means to be despised. By constantly saying that "land" or " commodities " are taxed, instead of saying " landowners " or " the consumers of commodities," we invite a confusion that may end in theories based on the idea, expressed or unexpressed, that it is indeed the land or the commodities that taxed.

A like confusion has come of the unhappy use of the word " reward" in discussing theories of interest, of "fund" to describe the total wage-payments of a year, of "capital," to signify something apart from the things that constitute capital, of " the return to capital," for the return to the owners of capital, of "wealth," when what is meant is welfare. All lapses into idolatry have come of making a convenient but insufficient symbol with the result that men come at times to view the symbol and the deity it represents as interchangeable. Since taxes are only paid by persons, it is better not to speak of land or goods paying taxes.

There is practically always, however, some convenience and relevance in methods of expression sanctioned and confirmed by long popular usage. In the present case, if a danger of ambiguity is introduced by saying " a tax is put on land," or " land is taxed," another danger is avoidedthe danger of implying by exclusive insistence on the fact that taxes are paid by persons, that it is irrelevant whether land or corn is taxed, because it is always persons that pay. "Some " persons pay, in any case. It is not always certain who pays. But it is certain that if land or corn are taxed, the prices of land or of corn will be affected.

It might be said that if a governing body gave nothing

1 But tributes are taxes paid by communities as a whole-though ultimately by persons. 
whatever in return for the taxes they demanded, people would not pay. If it were suggested that nations have in fact taxed tributary states, and given nothing in return, it might yet be urged that by the nature of the case, they do give one thing-government. It may be bad government, oppressive, ineffective : it may be the merest faint reflection of the prestige of the governor: yet it is government, it is something in return. Now, if a tributary state buys peace by a payment to a stronger power, there may be no taxation. If the tributary pays no more than it would cost otherwise (in whatever conditions exist) to gain a like peace, it is then buying something at a price, it is not being taxed, - unless it did not want peace at all, and was being forced to purchase with money which it valued a peace it did not value. The compulsion makes the tax.

If we consider how Passive Resisters are forced to contribute to Church schools, Quakers to the navy, Anarchists to the police, Churchmen to "Godless schools," Republicans to the monarch's income, Unionists to the salaries of the Irish Nationalist members, we find that taxes are constantly demanded and paid, not for " nothing in return," but what is worse, for something that the payers conceive to be more mischievous than if the money had been cast into the sea.

A tax carries with it no guarantee of services in return. The individual who pays cannot stipulate what he will have for it, cannot claim, when he pays $£ 8$, twice as much protection or other service as when he pays $£ 4$, cannot in any proper sense be held to have bought even government. Rajah Brooke could govern Sarawak, though no taxes were paid him. Taxes are paid because a governor compels, not that a governor may govern. Government is possible without taxes, but taxes are not possible without government.

III.

The common element between profits and taxes, as constituent parts of revenue, is that both are moneys, or moneyequivalents, paid by persons to a governing body. They 
are both payments, but one of them, profits, results from an actual barter or purchase, whilst the other is a forced payment, not part of a definite bargain.

It is not needful here, where we are to consider chiefly taxes, and not profits, to inquire minutely into the nature of profits. As men use the term in daily life, and in business, profits form the excess of incomings over expenditure, in transactions where there is an exchange of economic goods and services. Professor Marshall defines profits as the excess of total net gains on capital over the current rate (of interest). (Principles, II. iv. § 2.) In another place he says-

"When a man is engaged in business, his Profits for the year are the excess of his receipts from his business during the year over his outlay for his business; the difference between the value of his stock and plant at the end and at the beginning of the year being taken as part of his receipts or as part of his outlay, according as there has been an increase or decrease of value " ("Economics of Industry," Third Edition, II. iv., § 6).

"The profits of a business are the excess of its receipts over its outgoings, and the anniual rate of profits is the ratio which the yearly profits bear to the capital invested " (Ibid. VI. viii., § I).

Walker considers profits to be similar to rent in this, that they do not form a part of price.

Professor Charles Gide says-

"A large number of economists to-day consider the entrepreneur to have a monopoly (something like the landed proprietor, although with notable differences), and thus profit would appear as the revenue from a monopoly."

$\mathrm{He}$ makes references to Walras, Pareto, and Pantaleoni (Gide, “Principes d'Economie Politique," III. iv. I, § 3).

De Quincey, discussing Ricardo, says-

"In one brief formula, it might be said of profits that they are the leavings of wages: so much will the profit be upon any act of production, whether agricultural or manufacturing, as the wages upon that act permit to be left behind. But left behind from what? From the price."

"I have already observed," says Thorold Rogers, " that the rate of profit is to be identified with the rate of interest. Whatever else is secured to the capitalist, beyond the average rate of inter- 
est, is either wages of labour, i.e. the labour of superintendence, superior intelligence, and tact, and the task of supplying the purchaser with what he wants, all which are kinds of labour, wherein great skill is ordinarily necessary; or replacement of capital; or insurance against risk."

These few definitions are enough to show that it is easy to get into a long and involved inquiry, if we stop to examine minutely the nature of profits, and the views that have been expressed on the subject. For such an inquiry, however, this is not the fitting time and place. If we use the word in the usual sense of common speech, in the way in which men of business use it, and finally, with a connotation which is reasonable and ample for its use in application to revenue, we may consider ourselves justified without further inquiry.

Now in common speech, and in ordinary untechnical dictionaries, profit signifies gain, advantage, benefit, improvement, progress, valuable results, useful consequence, acquisition of anything valuable or advantageous ; and its history leads us back to the Latin proficio, profectus, to make progress to advance.

Secondly, a man of business reckons all excess of income over expenditure as profit, without first subtracting interest at the current rate, to find what his profit " really" is, without subtracting wages from price, or making any other calculation.

Whether this use of the word " profit " is applicable to the large class of items in revenue that are distinct from taxes, is to be decided by the fitness of such a use in relation to the revenues or incomes of private bodies engaged in similar transactions-companies, monopolists, landowners. competing firms : that is, we are thrown back, under this head, upon the correct economic definition, and that, according to the view already expounded here, must be implicit and more or less explicit in common language and usage.

We will only add a test-application of this use of the word "profits" in connection with revenue, by applying it to a passage in a description given by Professor Cannan. We will tabulate the passage, for convenience. 
(a) "When a person is employed and his gross receipts from his employer or employers are almost the same as his net receipts from the same source, we call his earnings his 'wages ' or 'salary.'

(b) "But if his gross receipts are much greater than his net receipts, if, that is to say, a considerable part of his gross receipts is payment for the use of instruments of production belonging to him or hired by him, or merely reimburses him for the cost of materials, then what he earns by his labour (which will be part or the whole of his net receipts) is called 'profit.'

(c) "Similarly, the earnings of the labour of an employer and the earnings of the independent workman who sells commodities ready made to his customers are called ' profit.' “. . . It is an abuse of terms to call the whole of the earnings of labour ' wages ' and to speak of 'profits' as if they comprised nothing but income derived from the possession of property" ("Elementary Political Economy," II. §).

We have here two elements suggested, which together make up "profits,"-earnings of labour (chiefly of an administrative kind) and income from property. It is from a consideration of the former that profits have been classed with wages, whilst examinations of the latter have resulted in profits being put with rent or interest. This is by no means the whole truth of the matter, for theories of the rent of ability, of quasi-rents, of the nature of interest, make part of the discussion.

Into this general question we do not need to enter. Our business is only to indicate such general relations as exist, in order to avoid the falsity which comes from considering a question utterly apart from its general bearings; to make sure that our particular brick, apart from its own setting and stability, does not contradict the lines of the general edifice. It may be that all incomes, private and corporate, may finally be most usefully divided into two parts only, earnings of labour and rents of all kinds. Under such a classification, for example, "interest" would not appear. It has yet to be demonstrated that " pure interest" exists.

In our use of the word, " profits " will include rents. This 
is a use of the word not at all in harmony with older economic systems of classification, but quite in harmony with the classification towards which we are likely to be led by more recent inquiries. For if the doctrine of quasi-rents be not altogether rejected, it must lead to the inclusion under this head of all payments made for the use of things lent or hired ; and that will extend the domain of " rent and quasirent" very far. So far will that domain reach, that the very existence of a pure interest on money, apart and distinct from quasi-rents for the use of things, may easily be challenged. If, then, rents are not to go under profits, as we are using the word, it is hard to say whether our heading "Profits" will cover anything worth having a heading for. For these reasons we are including under profits, all rents and quasi-rents, all " payment for the use of instruments of production belonging to or hired by " the State ; as well as all " earnings of labour" of the State.

With that we must leave the consideration of "profit" in general, and turn again to our immediate task, which is to apply the description given by Professor Cannan to State profits. The part we have tabulated under $(b)$, if applied to the profits of the Post Office, could be read thus-

(b) But if the gross receipts of the Post Office are much greater than its net receipts (the existing condition), if, that is to say, a considerable part of the gross receipts is payment for the use of instruments of production belonging to the State or hired by it, or merely reimburses the State for the cost of materials, then what the State earns by its labour (which will be part of the whole of its net receipts) is called "profit."

This description is quite relevant to the profits of the Post Office, and it may be assumed, so far as has appeared, that it is as applicable to all that class of payments made to governing bodies as the purchase money of definite benefits offered. The satisfactoriness of " profits " as a subdivision of revenue will incidentally be further tested as we proceed in our inquiry. 
We have now before us three elements that have been separated out in the course of our inquiry.

I. Compulsion.

2. Purchase : a Quid Pro Quo.

3. Personal nature of payments.

Of these three elements the first and third are common to all taxes, the second and third to payments made to governing bodies, companies, or individuals, in acts of economic exchange, and the whole three to some taxes, or more frequently, what are called rates, where there is compulsion, personal payment, and some sort of an earmarking of the amounts paid, for the provision of services ; services that may, in fact, be more or less definite, more or less proportioned to the payment, but are levied under no such guarantee. These combinations give us, respectively, taxes pure and simple; prices, from which come profits (or losses) to be credited or debited to the public revenue ; and a mixture of the two. That is, pure taxes, profits, mixed taxes.

As the payments that are made are seen to approach a position where they are offset against goods or services accepted, as equivalents, and are made under compulsion they cease to be taxes of any kind, and become prices. As they approach more completely the point where they are not offset against any measured definite services at all, and are compulsory, they cease to have any admixture of the priceelement, and become pure taxes. In all intermediate forms, they are mixed: they are taxes by virtue of being compulsory and of bearing no guarantee of a measured definite service, and they are not pure taxes because they are earmarked against certain classes of service. Measurables, like gas and water, may be tabulated in a list of prices ; immeasurables, like protection of life, cannot be so handled.

In order to round off our consideration of public finance in general, we may here make mention of Expenditure. In the table on p. 2I, Expenditure is divided into two parts, Productive, and Non-Productive. The former is subdivided into Expenditure that is productive of present goods and services, and Expenditure productive of future goods and services. This is a subdivision analogous to the idea of 
productiveness applied to the expenditure of an individual. A man "spends" for immediate use, or " saves" against future uses. His expenditure is for goods and services, or for " investing," that is devoting part of his expenditure to capital, which will ensure future goods and services. This is not the use made of the terms "productive" and " unproductive " in "The Wealth of Nations" (II. 3), and adopted by Professor Bastable ("Public Finance," I. viii. §2). Adam Smith and Professor Bastable take "productive expenditure" to mean such as will yield a revenue. This view has led to difficulties, and Professor Bastable suggests " economic" and "non-economic" expenditure. But expenditure is not necessarily "non-economic" because it does not secure a revenue. If a man purchases a bootlace, or the State builds a House of Parliament, the expenditure is in both cases economic though no revenue is thus secured, except the "real income " (or " real revenue ") of the enjoyment of economic goods, which is just as real in the case of a House of Parliament as in the case of a bootlace.

This last point has brought us to consider the analogy between the income of an individual and the revenue of a governing body, and as our present inquiry deals with revenue, and not with expenditure, we may leave the latter question with the slight mention already made, and consider the points of analogy between public and private income.

\section{IV.}

The revenue of a governing body, whether that body be an absolute monarch, a central executive power, or a parish council, resembles the total income of an individual. But the resemblance does not extend to identity in all aspects. In so far as revenue represents a gross amount expressible in money and coming in during a fixed period, such as a year, it is comparable with the income of an individual or of a business concern. If it be supplemented by borrowings, or by payments for the use of land or other property in its possession, or by profits from enterprises in which it takes part, the comparison is still close. What distinguishes the 


\section{TABLE OF THE RELATION OF TAXES TO REVENUE.}

\section{Public Finance} is of two parts

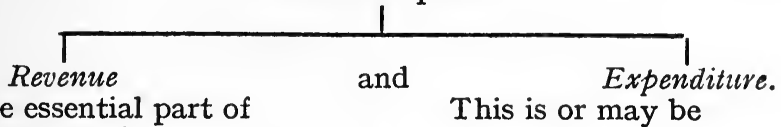

The essential part of

Revenue is

Net Revenue, which is made up of

TAXES and which are

(I) Compulsory

(2) Not purchase-

PROFITS

being

Labour
This is or may be

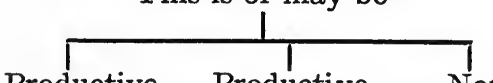

Productive Productive of present of future goods or services goods or productive of any services goods or services money
(I) Earnings of

(2) Rents and Quasi-Rents from property

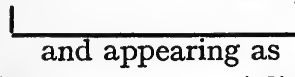

(a)

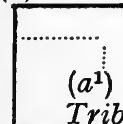

PURE TAXES

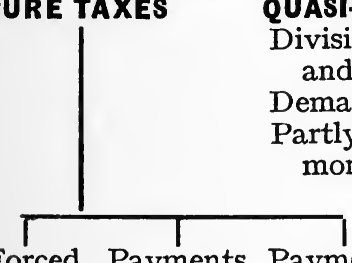

Forced Payments Payments services in kind in money.

Paid (I) by individual persons (2) in respect of
Property.
(i) owned
(ii) apprecia-
ated
(iii) inherited

\section{$(a b)$}

$\left(a b^{1}\right)$

Tributes

QUASI-TAXES

visible into $(a)$

as $(a)$

money, as $(b)$. $\left(b^{1}\right)$

Lotteries Borrowings

\section{PROFITS}

obtained from individual persons through transactions where specific measured goods or services are offered. They

\section{are}

\section{Monopolistic Competitive}

(I) at, or Monopoly (I) at, or $\left(\begin{array}{l}\text { Com- } \\ \text { peti- }\end{array}\right.$
(2) below Price
(2) below tive

(2) i.e. where private traders would not offer the same goods and services at lower rates.
(iii) inherited
(iv) bought or sold
(i) enjoyed
(ii) above a fixed standard
(iii) not related to present
personal
efforts
(i) produced
(ii) consumed
(iii) bought or sold
(iv) imported
(v) (rarely) ex- ported

\section{Income}

\section{Goods}

\section{Powers Granted}
(i) Monopolistic
(ii) Partly Mo- nopolistic 
revenue of a governing body from the income of an individual or of a business concern is the power to supplement its incomings by exactions that are irrespective of any apportioned services rendered by the governing body to the payers. This is taxation. It may be said that State income differs from private individual incomes in that it is not fixed in amount: a Chancellor of the Exchequer decides what he wants, and prepares estimates to ensure an income for the coming year to pay for it, whilst a private individual takes his income as the fixed thing, and decides what he can provide with it. But of course the Chancellor of the Exchequer is constantly working within fixed limits-what the Cabinet will stand, what the House of Commons will stand, what the electorate will stand-and more particularly, what those active elements in and out of the House, who feel their interests touched, will stand.

The idea of the income of an individual has been examined by economists closely enough to bring out the distinction between real income and money income, but a similar distinction has not been applied to revenue, or we should not express ourselves, as for example Professor Bastable does, in terms like these-

"For instance, the many buildings existing in the United Kingdom for the meetings of legislative bodies, sovereign and subordinate-from the Houses of Parliament down to the smallest town-hall-are certainly embodiments of value, but do not, except in very rare cases, bring in a return " (" Public Finance," I. viii., § 2).

We cannot view revenue as "real revenue" and " money revenue," without doing violence to language. Yet from the social point of view, a House of Parliament " brings in a return " of " real income," just as much as a wealthy man's shooting box, or yacht, or house. A system of classification which would keep our minds fixed on money income, and allow us constantly to forget real income, the more important thing, is by no means satisfactory. The fact that the word " revenue" does not lend itself to a use that would keep us in mind of what we may call for the moment "real State-income" demands that we should avoid using terms 
like "productive" and " unproductive" in such a way as would remove the conception of the real thing still further from our minds.

There is no need, in this connection, for any separation of rates from taxes. What we are concerned with is that part of the revenue of a governing body which is demanded of the individuals governed, irrespective of services rendered. It may be quite open to these individuals, should they feel that the general services rendered by the governing body are not worth the sacrifice which the demands call for, to limit the powers of that body, or to take other action. But there is not, in the case of taxes properly so called, any immediate or quantitative relation between the taxes paid by an individual and the services received by him. The administrative use of the words "rate" and "tax," to signify payments to local or to central bodies, has no particular value in the realm of economic inquiry. All taxes and rates are more or less local, and will be, until a WorldState is formed. Under our classification, the most striking distinction between rates and taxes will be that rates for the most part consist of mixed (quasi-)taxes, and must therefore be considered no less as part of a theory of profits than as part of a theory of taxation.

If we are to consider the prices paid for goods and services offered by a community, as prices paid to private traders are considered, it will be necessary to establish some method of judging State-prices, that will leave us satisfied that there is or is not a tax-element present. Let us consider the case of the Post Office. It has often been said that a private company could probably carry and deliver all the letters posted and delivered within the London area for a halfpenny, and yet make a substantial profit. This argument, however, assumes a service confined to London. If we limit the discussion to a London service, then if a private company would supply that area at a halfpenny rate, the present charge might be described as containing a tax of fifty per cent. But this hypothetical isolation of London makes the argument unreal. There are certain of the services rendered by the general post office system, such as carrying 
letters from an inland Scottish village to a small postal area in central India, that are charged less than the cost of the service rendered. There are others, such perhaps as the intra-London service, where more is charged than need have been charged if that part of the general post office work were carried on as a complete and separate undertaking. Under a private-enterprise postal system, there would probably be no carriage of letters at all in any branches of the work that had to be carried on at a loss (in themselves) except in so far as they stimulated the profitable branches so that the loss was more than covered. The question is one of apportioning the charges for services into such groups and at such amounts as will bring in the maximum net revenue, and of obtaining for the nation the greatest possible total of utilities for the total expenditure. A private firm would only consider the former case. If we separate out certain items, we may get some where the price of the postagestamps includes an item of tax, reckoned on that individual transaction, and others where there is a negative tax : where the payment made does not cover the expenses of the individual transaction. If the whole system were handed over to a private company, under an agreement that none of the present services should be withdrawn, then we might expect changes along these lines-

(I) The unprofitable services would be charged at a higher rate, and would be discouraged in other ways.

(2) The most profitable services would be charged at a lower rate, wherever the demand for them was elastic enough to make it likely that a lower rate would yield a higher net return. The likeliest case is that of a halfpenny letter-rate for letters posted and delivered within certain town areas.

(3) The scale of charges would be less simple, and would approximate more than it does at present to the standard of "payment according to services rendered."

If, under such a system, the citizens as a whole paid less per annum than they do at present for services equivalent to those they obtain under the State system, they are taxed. Some individuals, of course, would be sure to gain, some sure to lose. Most people think they would lose, for if that were 
not so, we should have a vigorous and healthy agitation for a non-State postal system. The inference is that people think that they are not taxed, taking the system as a whole. There is an alternative inference, that people think they are taxed in this direction, but are as content to pay the tax in that way as in any other. But in any case postal taxation is not proved by the mere fact that the Post Office makes a profit. We do not call the profits of a Gas Company, which monopolises a district, a tax. Could we get our present postal service from a private firm at less than the present postal charges? If not, there is no tax.

It is possible, on the other hand, that some exactions which are called taxes may contain elements that are not taxes at all, but proportionate charges for services rendered. In so far as a stamp duty represents the actual cost of offering legal protection to the parties of a business transaction where stamps are used, it may be said to contain an element of charge for services rendered, and this charge belongs rightly to Non-Tax Revenue. It would be quite impossible, however, to separate out this part, for we cannot assess it even by bringing in a purely hypothetical pri ate company to do the work. It is work that a private company cannot do. Our local finance furnishes less debatable examples. A rate levied for water supplied by a municipal body, and assessed according to rental value, as is usual, resembles a purchase of goods, and there is some attempt at fixing the price according to the amount of service rendered, or according to some standard adopted. But the charge for lighting a town will often include curious discrepancies. A recluse living in a distant bungalow might be quite unmoved if all the town were left in darkness, whilst the difference between dark and light streets might easily represent, to a tradesman in the High Street, several times the amount of rates that he pays under this head.

These mixed or Quasi-Taxes are very common in local finance, but they are not peculiar to it, as we have seen, nor are they, in their nature, any more related to what we call rates than to what we call taxes.

However important the distinction between rates and 
taxes may be, considered from an administrative point of view, there is no distinction whatever between them according to the definition of a tax that we are here adopting. By custom, a monetary demand from the Central Authority in England is usually called a tax : a similar demand from a Local Authority is called a rate. This aistinction is quite empirical, and, for purposes of analysis, useless. A more useful distinction is that based on the method of assessment. A tax is fixed at so much per unit, as per pound sterling of income, and the total revenue it will bring in is uncertain, though it may be calculated approximately, especially where the experience of former years is available. A rate is levied with the object of obtaining a definite amount, and that amount is apportioned among the payers. It is the apportioning that makes it a rate.

Even this distinction is not of primary importance for the purpose of an inquiry into the theory of taxation. The rate and the tax are, both of them, arbitrary exactions, in the true sense of the word arbitrary, and the payment of them does not carry with it a claim to benefits proportioned to the tax paid. This is a definite characteristic of a tax, and it is equally a characteristic of the tax-element in a rate. It may fairly be urged, however, that since in actual fact there is a great deal of rough proportioning of benefits to payment in the case of many rates, and relatively little of it in most taxes, no definition or classification would be satisfactory that did not recognise this fact, or, at least, that implied a partial denial of it.

"The 'rate' is, of course, the rate-in-the-pound," writes Professor Cannan, " and the question is, why did the local exactions receive this name instead of being called 'taxes'? Was it not because the local rate seemed to be a local friendly arrangement, while the tax came down from some higher power?"

An outline of the history of the use of the word, as given by Dr. Murray, is quoted in the Appendix to this chapter.

The charges made by a governing body may be according to a strictly quantitative scale. The payments are then proportionate to the amount of the commodity taken, or to the service rendered, and whether any element of Pure 
Tax is included will depend upon the probability or possibility of a private firm, or firms, supplying the same article or service at lower rates. Such a system obtains with regard to the supply of gas.

A commodity such as water, however, is only charged for by measure in places where it is so scarce and dear as to be worth the cost of measuring, in addition to the cost of distributing. Where, as usually happens, it is not worth the cost of measuring, there are these practical alternatives open-

(I) The charge may be equally distributed over individuals, or over householders.

(2) The charge may be apportioned according to some scale or standard, likely in itself to vary with a more or less close approximation to the quantities supplied.

(3) The charge may be apportioned according to some scale or standard, quite unrelated to the quantity of water consumed, but chosen as indicative of general ability to pay.

Under the first of these systems, individuals who use little water will be paying Pure Taxes as part of the charges laid on them. In some cases, the greater part of the payments will be Pure Taxes. There will probably be others, the users of water in large quantities, who will be enjoying Negative Taxes: that is, they will be paying less per unit for their supply of water than they would have paid had the water been supplied by private enterprise. The same kind of thing will happen under the third system, and, to a limited extent, under the second. A particularly suitable standard might give, under the second system, a scale of charges approximating very closely to a system of payments according to quantities consumed, and in such a case, few Pure Taxes or Negative Taxes would appear.

The standard taken as the basis of our local rates, where measurement is inconvenient or too expensive, is the rateable value of fixed property, assessed from valuations made. It is quite apparent that this standard must for most purposes be considered as falling under the third rather than under the second system. It was chosen, as the history of the Poor Rate shows, rather because it indicated a reasonable 
scale of abilities to pay, than as a scale measuring benefits received. It has been justified and criticised on both grounds. Its practical justification, of course, is its general adoption and extension, and this suggests that it cannot be, on the average of cases, very far removed from our second system, where the standard of rating does vary, however roughly, with the quantity of service rendered. Otherwise, some other standard would have been adopted, or at least suggested.

\section{V.}

We have already separated out two elements, which we have called Pure Taxes and Profits, and we have seen that the revenues of local and of central governing bodies fall under one of these two heads, or consist of payments containing both elements in varying proportions. Pure Taxes thus appear as payments made to a ruling body, which do not constitute any claim to proportionate benefits in return. The word " benefits " must here be confined to its economic meaning. In a country where taxpayers, and they only, exercise the franchise, it might be said that a share in the control of the State was really a benefit received in return for payments made, and under a system of multiple voting on a property basis, the benefit might easily be made proportionate to the taxes paid.

It will be necessary to keep the term "Pure Tax" distinct from the more general term "Tax." The latter we must leave untouched. It is a fixed part of the language, and it should be used for what it is generally understood to imply, neither more nor less. The use of another term"Pure Taxes"-is necessary to separate out the element that makes taxation a distinctive thing, and to enable us to deal with that element without ambiguity. It has already been used in this sense, and it suggests its true relation to "Quasi-Taxes."

There is one small point that may be mentioned and left. Taxes are not invariably paid in money, but in modern times, and in modern states, they are paid in money only, with one possible exception. Compulsory military service 
is often spoken of as a tax, by a figure of speech that reverts to the origin of the word. But the use is always intentionally figurative, and never literal. In a social or national sense, compulsory service, whether military or other, is a tax upon the productive powers of the nation, unless we are to speak of "producing" security. In an individual sense, a conscript is taxed to the extent of the difference between what he would have earned, if not called to service, and what he does earn during the time of service, with some adjustment to be made based on his producing powers at the end of his term as against what they would have been had he been left free. By general consent, the net social gain or loss due to conscription is held far more serious than the net individual gain or loss, however great these may in many cases be. The opposite view is taken of another "tax" not paid in money-the service of unpaid jurymen. Here, by common agreement, the net social gain is held to be so great as to override the net individual loss. That, of course, is no reason for maintaining a system of individual losses, but only for securing the social gain. But we need not hold ourselves bound to include " taxes" of personal service in our inquiry. What we only describe as taxes by a more or less conscious use of a figure of speech, can be omitted in an inquiry into principles without any fear of a consequent falsification. We may now put into formal shape the definitions of the terms we have dealt with.

Taxes are compulsory payments made by persons to a governing body, and not guaranteeing definite measured services.

Pure Taxes are Taxes and no more: compulsory payments made by persons to a governing body, and not guaranteeing any definite measured services.

Quasi-Taxes are Taxes with a non-tax addition : compulsory payments made by persons to a governing body, and resolvable into two parts, one being a quantitative payment for proportionally quantitative services (that is, a price), and the other a Pure Tax.

Prices are quantitative payments for proportionally quantitative services. 
Profits are the excess of income over expenditure, in transactions where there is an exchange of economic goods or services. Thus Taxes are either pure or mixed. If pure, they fall under the definition of Pure Taxes. If mixed, under that of Quasi-Taxes. The element of compulsion, and the relation to service rendered, may be tabulated for the two pure cases of Tax and Price, and for the intermediate case where both exist.

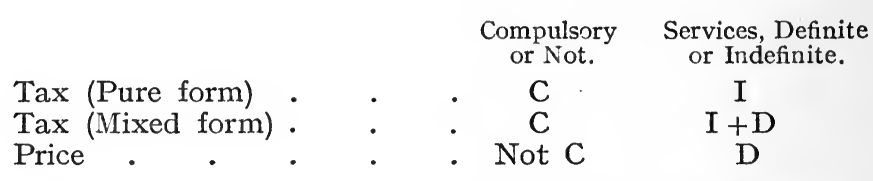

This classification leaves the word "tax" as it stands in common use, to include a greater or less proportion of what is really payment for services, whilst always implying a task imposed. It marks out from this whole the part that is quite dissociated from services rendered in equivalence or practical equivalence of the tax, and places that part under a distinctive name, Pure Tax.

We have said that we are not in this inquiry under the necessity of dealing with the word " rate," for although we are dealing somewhat meticulously with words, it is in order to get as closely as possible to the ideas that the words cover-and sometimes hide. We shall deal with all the elements in "rates" in dealing with those in "taxes." The word "rate" is or has been used to mean-

(a) a payment made to a minor governing body;

(b) a tax levied as an apportioned fraction of a fixed sum;

(c) a scale of assessment.

The older sense is better preserved in the term "rating" than in the term " rates" (Lat. reor, ratus, to think, deem, judge. Latin synonyms (Dr. Carey), puto, censeo, opinor, judico, existimo). At the next stage, a rate becomes the standard by which a value is adjusted or "rated "; or the value itself so obtained; or the tax, so estimated. Modern usage applies the word "rate" to most locally-collected taxes-but not to all, for we speak of a dog-licence, and not of a dog-rate. 
A similar confusion has arisen in France over "taxe" and "taxer," which refer primarily to rating, regulating, assessment, and secondarily to taxing.

\section{VI.}

In any analysis of revenue where it is useful to inquire into the nature of that part of the revenue to be classed as profits, some principle must be adopted in separating out from these profits any element of pure tax that they may contain. There is by no means a general agreement as to the principle that should be adopted. In the autumn of I897, a list of fifteen questions on taxation was sent to sixteen men who may properly be described as experts on the subject, and as one of the questions (No. 3) referred directly to the correct description of the net revenue of the Post Office, we may with advantage consider the answers given, grouping them in the way most convenient for our present purpose. The answers are given in the Bluebook C. 9528 , 1899, under the title "Memoranda, chiefly relating to the Classification and Incidence of Imperial and Local Taxes."

It may be said broadly that the answers of those who are best described as politicians or public men, were on the whole squarely in favour of describing the profits (" net revenue ") of the Post Office as a tax. The economists, as might be expected, gave more cautious and more discriminating replies. They fall into two groups. Either they say that the Post Office profits are taxes of a special kind marked out by the Government monopoly in lettercarrying, or they say that the net revenue is only a tax in that it contains, or may contain, an element of pure taxes : that is, they would class it as a mixed tax.

The group that we have called the "politician" group includes Sir E. W. Hamilton (who claims also Mr. Goschen as taking the same position), Lord Farrer, the Right Hon. H. L. Courtney (Lord Courtney), Sir G. L. Gomme, Mr. J. W. S. Caillie, and Professor Gonner. To these may be added Sir Robert Giffen, who held that not only the net 
revenue, but the gross revenue of the Post Office should be included " in any statement of taxation." Mr. T. Mackay thinks " there can be no doubt that any profit which it (the Post Office) makes is a tax," and as he sketches the institution as an inefficient "monopoly, he would perhaps be ready to class more than net revenue as taxation.

Before we leave this group, it will be well to consider the influence exerted by the definition of a tax which has been taken by the different writers. In some cases, the answers contain a definition, and must be considered in the light of the definition chosen. The following definitions are given by members of this group.

Sir E. W. Hamilton :-

"A tax, or rate, is an obligatory contribution by persons in respect of, or incidental to, something which they possess or something which they do" (p. 33).

\section{Sir Robert Giffen :-}

" Taxes in the proper sense of the word, viz. contributions by individual members of the community to the expenses of the State" (p. 93).

Sir G. L. Gomme :-

"If a tax falls in exact proportion to the benefit conferred in respect of such tax there is no incidence of taxation in the strictest sense because taxation has not occurred." " . . . taxation pure and simple only occurs where the charge falls (I) in no relationship to the benefit conferred; (2) where it is in excess of the benefit conferred" (p. 237).

\section{Professor Gonner :-}

"Taxation is the exaction from the various members of the State of contributions towards the common expenditure" (p. I45).

"Taxes are the contributions exacted from persons who are members of the State towards its general expenditure" (p. I49). "Taxes are contributions towards the general expenditure, Imperial or local, of the State, exacted from its members in [respect of something they possess, or something they do " (p. I49).

These definitions, with the exception of Sir L. Gomme's, would include all branches of revenue except loans and tribute. They exclude, where "members of the State" 
(Professor Gonner) or " members of the community" (Sir Robert Giffen), are specified, any part of customs duties that may be "paid by the foreigner." They would take in all that we have classed as Pure Taxes, Mixed Taxes, or Profits. The definitions of Sir E. W. Hamilton, Sir Robert Giffen, and Professor Gonner demand that not only the net revenue, but the gross revenue of the Post Office shall be classed under "Taxation"; and Sir Robert Giffen quite rightly, under his definition, puts it so. For the expenditure of a State Post Office is " a contribution towards general expenditure": the whole of the payments are obligatory on all civilised people except the few who prefer abstaining from correspondence to buying postage-stamps : and the contribution is "in respect of or incidental to something which they do."

The obligatory nature of the payments for postal services, as of what are classed as indirect taxes, has been affirmed and denied, and it will be well to examine such payments before we proceed further. The question has usually been discussed in relation to taxes upon commodities, but the arguments apply to taxes upon services also; moreover, postage-stamps are commodities.

Adam Smith considered that such taxes were not obligatory. He said of them :-

"As he (the consumer) is at liberty too, either to buy or not to buy, as he pleases, it must be his own fault if he ever suffers any considerable inconveniency from such taxes" ("Wealth of Nations," Bk. V., Chap. ii., part ii., § iii.).

Mill rejected this view as fallacious. In Bk. V. Chap. vi. $\S$ I of the "Principles of Political Economy," he writes :-

"There is, however, a frequent plea in support of indirect taxation which must be altogether rejected, as grounded on a fallacy. We are often told that taxes on commodities are far less burdensome than other taxes, because the contributor can escape from them by ceasing to use the taxed commodity. $\mathrm{He}$ certainly can, if that be his object, deprive the government of the money; but he does so by a sacrifice of his own indulgences, which (if he chose to undergo it) would equally make up to him for the same amount taken from him by direct taxation." 
In the "Science des Finances" of Boucard et Jèze, a similar view is expressed :-

"All taxes are compulsory. It has been claimed that taxes on consumption are optional (facultatifs), seeing that every one is free not to consume. It would be just as true to say that taxes on land (l'impôt foncier) are not compulsory, since it is open to the owner of an estate to cease to be the owner " (p. 238, edition of I904).

Professor Bastable carries the argument further.

"A citizen can indeed escape a wine duty by not consuming wine. That course, however, has the double disadvantage of depriving the State of revenue and of diminishing his own enjoyment."

Whatever case is likely to be framed in favour of regarding any kind of taxes as optional, is brought up against two facts: that if they are optional, most of them will remain unpaid, and that it is the essence of a tax that it is not optional but compulsory. As it becomes optional, it ceases to be a tax, unless we are to let words like "tax" and " gift" stand for similar conceptions.

If so wide an extension of the term " taxation " as implied by this group of definitions is to be accepted, then the whole revenue of the State, apart from loans and tribute, will properly be called "Taxation." Sir Robert Giffen takes this wide definition, and applies it logically. If the State owned the railways of the country, Sir Robert would then reckon every penny spent on railway tickets as taxes, just as he here reckons with respect to postage-stamps.

But this is not the ordinary sense of the word " taxation." If nationalisation of the railways came about in these islands, the average Englishman would not, on his own initiative, call the money he spent on tickets a tax-except in so far as he judged the payment to be in excess of what the companies would have charged him, or used to charge him. He does not at present count his municipal tram fares among. his rates. In his method of reckoning what are and what are not taxes, he is to be classed with the economist group rather than with the politician group.

Before we deal with the other answers, we may note that 
Sir L. Gomme measures the " benefit conferred " by the net cost of the service rendered, and puts the excess (net revenue) as taxation pure and simple. He makes no comparisons with private enterprise, but considers all State profits as Pure Taxes. He says:-

"The net revenue of the Post Office is, in my judgment, correctly treated as a tax, and I think it might just as properly be classed under the heading of "Taxes levied in respect of commodities' as under the present rather unmeaning heading of 'Miscellaneous Taxes.' It is a tax upon the persons using the letter-carrying industry performed by the Government."

Now this raises the question of what is to be put, under the classification we are adopting, in our group of Profits, and in our group of Taxes, Pure and Mixed. For wherever Profits form an item of Revenue, it will be necessary for us to separate out any element of pure taxation that is contained in such parts of profit as "the net revenue of the Post Office" discussed in the "Memoranda." For this we shall need some principle, and as a help towards finding it we may gather together the opinions expressed in the "Memoranda." We have not yet set out the definitions offered by the economist group : but of these, the only two that are given in the replies are bound up with this very inquiry. The method used in separating taxes from profits quite properly springs from the definition of taxes which is adopted.

The following are the two cases.

Professor Edgeworth :-

"What is the best definition of a tax is an interminable inquiry. There is a whole literature on the subject on the Continent. . . . For the present purpose we may accept Professor Bastable's definition of a tax, and understand with him that "when ordinary profit is exceeded, the monopoly possessed by the [public] office is employed for taxation " "Public Finance," II. i., § 4). Or, in Professor Sidgwick's words, ' Government avoids interfering with distribution '-whether in the way of tax or bounty - ' if it sells the commodity at the price at which it would be sold if provided by private industry' ("Political Economy," III. viii.). But 'we can only conjecture roughly what the price would have been.' We do not know to what extent the service would be monopolised in the absence of Govern- 
mental interference. The calculation is further complicated by the possibility that, whether in a régime of perfect competition, or more or less imperfect monopoly, there might be different prices, varying with the cost of service in different localities. It has further to be considered that the burden imposed on the public by the Government monopoly of the post is not to be measured simply by the rise in price which it may occasion. Professor Marshall, in a 'letter to The Times of April 6, I89r, estimated the loss to the public in the way of 'consumers' rent ' consequent on the prohibition of private enterprise in postal services, as amounting to some four and a half million sterling pounds annually. It seems to follow that 'the net revenue of the Post Office' is a very inaccurate measure of the fiscal burden imposed by the Government monopoly."

\section{Professor Gonner :-}

"Taxation is the exaction from the various members of the State of contributions towards the common expenditure.

"I feel no doubt as to the soundness of the decision in regard to the net revenue of the Post Office as a tax, and to place it under the heading of 'Miscellaneous taxes not incidental to property.' ... . Taxes are the contributions exacted from persons who are members of the State towards its general expenditure. If this is so, payments made by the individual to the State in regard of definite personal services are taxes, in so far as they are in excess of the cost incurred. The mere fact that they are, in the first instance, exacted from persons availing themselves of these services is not sufficient to deprive them of the character of a tax like any other tax, a tax on communication, which this net revenue represents, is open to the charge of arbitrariness in its imposition. Many definitions are offered by various writers. In view of the considerations put forward above, I would add one. Taxes are contributions towards the general expenditure, Imperial or local, of the State, exacted by it from its members in respect of something they possess, or something they do. This definition, which corresponds in many ways with that laid down by Sir Edward Hamilton in his Memorandum, if rigidly construed, removes from the category of strict taxes payments made to cover the cost of personal services by the State."

Let us note first of all that the alternative offered us by Professor Edgeworth is indefinite. $\mathrm{He}$ cites Professor Bastable's rule, that " where ordinary profit is exceeded, the monopoly possessed by the public office is employed for taxation." Unless "ordinary profit" is taken to mean 
"ordinary monopoly profits," which is not what it should mean, we have here a contrast between private enterprise competitive prices and State monopolistic prices. It is not always the fact that monopoly prices are higher than competitive prices, and in some cases, if we were to assess taxes by subtracting State monopoly prices from private competitive prices we should get a negative tax. The alternative rule quoted from Professor Sidgwick is more satisfactory. There is no tax if the State sells the commodity " at the price at which it would be provided by private industry." Whether this occurs as between a State monopoly and a private monopoly, or between competing State and private systems (like the London County Council trams and the motor-buses on their routes), or between a State monopoly and competing private firms, is indifferent. If the public is getting an article or service from the State at the price that would have to be paid if the State withdrew, there is no tax.

"Professor Sidgwick's rule is applied to test the case where "Government avoids interfering with distribution." This is not quite the same thing as the case where there is no tax, but, except in one hypothetical case, it comes to just the same thing. If the taxes of a State could be so graduated that every one was left, after paying his taxes, in exactly the same state of welfare, relatively to every one else, as existed before the levy, then distribution has not been altered : that is, the proportion in which goods and services are distributed is unaltered. But the total of goods and services received by each one who pays the tax is altered: all are poorer off, pending the decision of the method of expenditure by the State. If every one gets back from the State just the kind and just the amount of goods or services that he would have purchased with the money that went to the tax, there is no ultimate effect of the tax. In so far as each gets a less return than this, he is taxed.

Where the State, then, charges no more than would be charged by whatever individuals or bodies would step in when State-service ceased, there is no tax.

A clearer view of the general relations of the facts we are 
discussing will be obtained by a consideration of some specimen services and commodities, arranged to suit the ideas we have been setting out. Take the goods and services represented by these terms-a Public Elementary School, a High Road, a Street, a Bridge, a Tunnel, a Ferry, PostageStamps, a Railway, Diamonds, Bread.

The expenses of a Public Elementary School are met by payments made to the State and to a local authority. The payments made to the State are according to income (but not proportionally) as in the Income Tax; according to the amount of beer, spirits, tobacco, currants, and so forth, purchased by the taxpayer; according to the number and extent of the legal transactions in which he engages; according to values that he may inherit; according to a score of things in his way of living. His payments in rates are according to an assessment made on the fixed property he occupies. In no way is there any direct relation between the payments he makes and the benefits, if any, that he receives. He may have no children, and may account it a benefit or a source of irritation that his neighbour's children sing "John Peel" or chant multiplication tables by his garden fence.

From a High Road he will get some benefit in person, when he walks or cycles or motors along it: and further benefits less directly, with regard to the goods that are brought for his use along high roads. But his payments are not assessed according to the miles he travels on high roads, or the quantity of goods brought to his door, but according to a standard that only roughly represents these things, and often does not represent them at all-his rent.

His own street comes closer to his individual uses: yet if he invariably left his house by aeroplane, and never stepped in the street, he would not pay a penny the less.

He would pay for the benefit obtained from a bridge, if a system of tolls obtained, exactly in proportion to his use of it. But where there are no tolls, he pays although he may cross the river always in his private boat.

In some cases he pays for the use of a tunnel according to the number of times he passes through it, as in the case 
of the Severn Tunnel, where an extra charge is made on passengers. A like thing occurs in connection with the Forth Bridge. But in general, a passenger on the railway who goes through ten tunnels on a hundred-mile journey pays no more than a passenger on another hundred-mile run where there are no tunnels.

As for Postage-Stamps, he pays a penny for the stamp that will have his letter taken across the street, and a penny for the stamp that will take a similar letter across the Indian Ocean; he pays less to have a bulky newspaper taken to Dublin than to have a slim letter-card taken to the same place. Service may differ enormously while payments are similar, and payments may differ whilst services are practically identical-as where a $3 \frac{9}{10} \mathrm{oz}$. letter is carried for a penny, and a $4 \frac{1}{10} \mathrm{oz}$. letter for three-halfpence.

Railway charges are fixed, in England, according to a system of Monopoly tempered by legislation. The Parliamentary rate of a penny a mile is not based on the expense of working the mile of rail that is travelled, but mainly upon a legal enactment that adopted miles as a rough standard by which services might be in some sense measured.

The prices of diamonds, again, are largely monopolyprices, the output being regulated-in particular by the great De Beers Company.

Finally, the price of bread may be fairly taken as a competition-price ; and payments are directly regulated according to the quantity of the commodity, of a certain grade, that is supplied.

These examples illustrate the steps that lie between pure taxes and prices. They suggest a great number of actual and possible payments lying between taxes and prices, and they indicate some methods of assessing payments. Of such methods we may mention:-

(a) Payments according to exact quantities, measured, as in yards of cloth; weighed, as in pounds of bread; counted, as in reams of paper.

(b) Payments according to approximate quantities, calculated by some standard, more or less closely related 
to the use of the goods or services : as when waterrates are reckoned according to rents.

(c) Payments that are not graded according to the actual or approximate quantities of the goods and services supplied, but according to some unrelated thing, such as the income of the payer.

These correspond very closely to our classification of taxes, quasi-taxes, and prices ; but it may be noticed that the second group covers a great deal of the moneys paid to local authorities under the form of rates.

What emerges from our analysis is a whole series of taxforms, from the pure tax which is tax and nothing else (in this relation) to the " tax" which contains but the tiniest fraction of real tax in its amount. Then we come to profits, which may or may not be called "taxes ": payments of such monopoly or competitive prices as would be paid if the services supplied were those of a private-adventure concern, payments for which the payer gets exactly as much in return as he would get if the State or other governing body ceased to supply the services. Beyond this, there may be cases where the payer receives from the governing body more services or goods than he could purchase for the same money if the State supply ceased. Here would be negative taxes.

The accompanying diagram is an attempt to represent the whole series. The area $\mathrm{A}$, which represents Pure Taxes, varies from the possibility of the upper portion, ax, which is balanced by no return whatever in the shape of goods or services, to that of the lower portion (A 3), which is linked with a large though undefined amount of services. The dotted boundary lines represent the indefiniteness of these services (a).

The Quasi-Taxes, B, are shown as consisting of two distinct parts, one of which, dotted, is really a price paid for the equivalent services $\beta$, the remaining part being a pure tax, to which corresponds the area of indefinite services, $a a$, not quantitatively corresponding, so that the smallest pure-tax contribution in $\mathrm{B}$, which is $\mathrm{B} 4^{\mathbf{1}}$, may be offset by the largest amount of undefined services, $\beta a a$. 


\section{Diagrammatic View of Taxes and Prices}

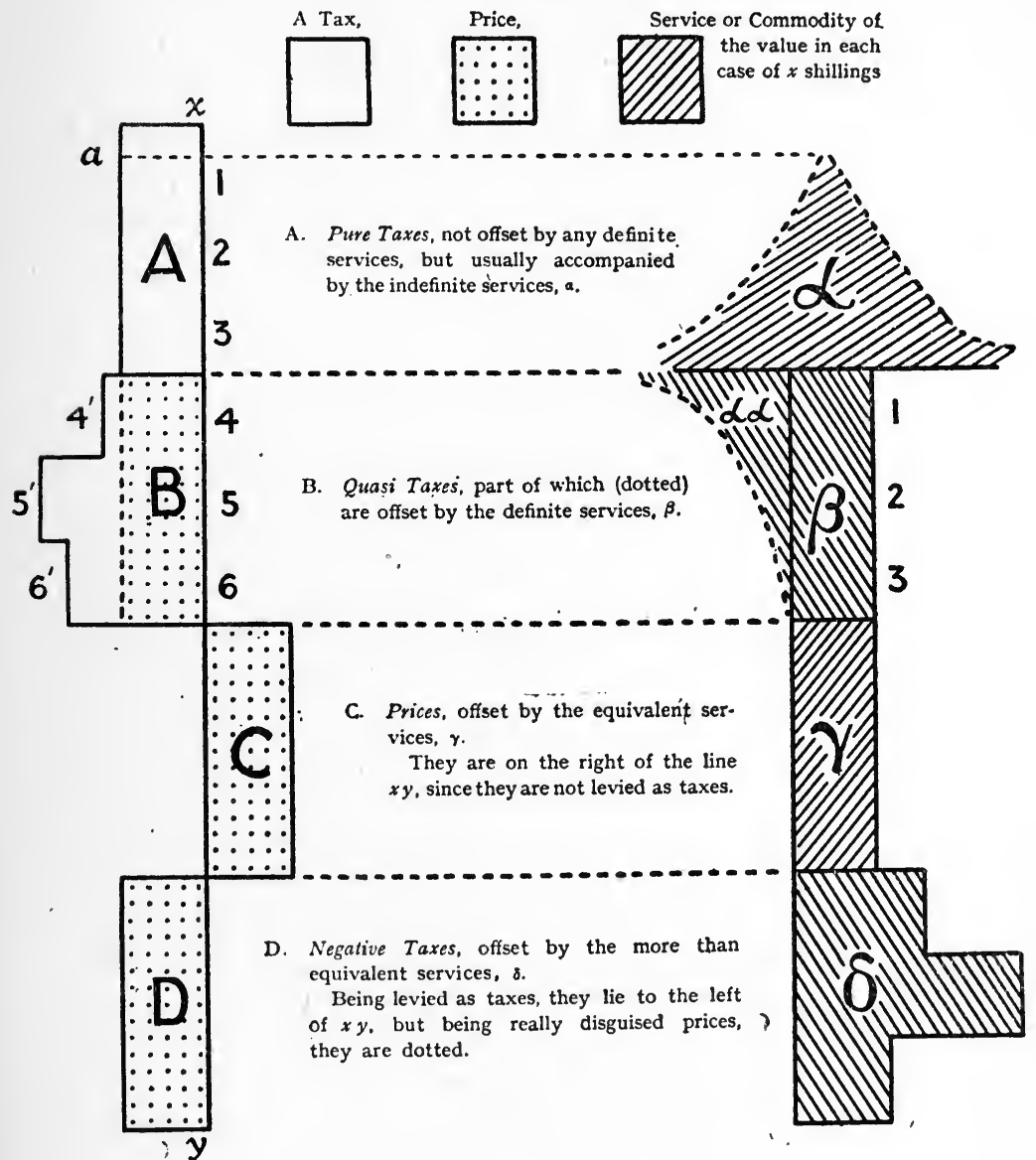


At $\mathrm{C}$ we have prices pure and simple, dotted like the price payments in $\mathrm{B}$, but lying to the right of the line $\mathrm{xy}$, since they are not levied as taxes ; we have put all payments levied as taxes to the left of xy.

The converse of Quasi-Taxes occurs at B, where the area drawn to represent definite services $(\delta)$ is greater than the area drawn to represent the taxes paid. We take $\gamma$ to represent the services or goods obtainable for a payment of the prices $\mathrm{C}$, and $\boldsymbol{\gamma}$ (or a part of $\delta$ equal to $\gamma$ ) as consequently equivalent to the services or goods that would be obtainable for the payments $D$, were the State services withdrawn. This case we describe as Negative Taxes.

\section{VII.}

We may now review the course of our argument so far, and summarise the conclusions at which we have arrived.

We have found only two essential constituents of (net) revenue-Taxes and Profits. As the question of expenditure does not come within our inquiry, we have dismissed it briefly, making a division of its parts that is based upon the idea of Productivity. As for the two elements of Revenue, we find them actually appearing in three main forms, Pure Taxes, Quasi-Taxes, and Profits. The Pure Tax is an unmixed element, and we infer that it is here we must direct our attention in searching for the essential principle of taxation. Pure Taxes may consist of payments in money, or in kind, or in services. They are levied in respect of (I) property or income possessed, (2) exchange or increase of wealth, (3) powers granted. Tributes may in some cases be considered as Pure Taxes, but are better classed with Quasi-Taxes. These latter we do not treat of or examine in themselves, but only in the parts into which they are resolvable-Pure Taxes and Profits. With Profits we put Borrowings and Lotteries. We consider them under the headings of Monopolistic and Competitive, judging State Profits by the standards we should apply to private profits, choosing in each case that form which would probably be established if State action were to cease (see again p. 2I). 
The essential feature of a tax then emerges as a result of the opposition of Profits and Taxes as elements in revenue, or the opposition of tax-payments and price-payments (purchase-payments). This brings us to Compulsion as the essential mark of tax-payments; and in this connection we correlated "tax" with "task." Slave-labour is taxlabour; free labour is payment-labour. The slave-owner will certainly give services to his taxpayers-food, clothing, protection : but the slaves do not by their labour purchase these things from him.

A tax, then, is a payment compelled, and the compelling power does not guarantee a definite return; while a price represents one side of an exchange, the result of immediate or mediate bargaining. A tax is not derived from any bargaining except that vague element expressed by the fallen phrase "social contract." If the people of a nation are willing to surrender the whole of their incomes to the governing power, upon a definite understanding that they shall receive in return certain goods and services, then so long as the people are free to have these services supplied in some other way, and do not care to make the change, they are not taxed at all. For in such a case neither of the two elements of taxation appears : first, there is no compulsion, and secondly, there is a guarantee of a definite fixed return in goods and services accepted as equivalents.

We have taken a chapter to answer the simple question, "What is a Tax?" In answering the question, we have had the historical evidence before us-as expressed in definitions-in such completeness as to afford material for finding a satisfactory answer. ${ }^{1}$ If it be urged that the answer is not satisfactory, it can at least be said that the bulk of the evidence has been "laid on the table." We have set forth a definite theory of the true place of taxes in the scheme of public finance, consistent with the conception of taxes arrived at. Incidentally, too, but not, we think, needlessly, we have considered the principle of nomenclature proper to economic science.

We may pass on, now, to a consideration of the historical 1 Appendix to Chapter I., pp. 246-269. 
development of ideas about taxation-ideas that may be called fundamental in the theory of taxation. Here also, at the risk of tedium, we propose to lay out the evidence in detail, making provision for those readers (quite possibly a majority) who are unwilling to examine all the details.

The reader who has not yet referred to the appendix to this chapter (p. 246 et seq.) will find, upon a little examination, that the definitions of "Tax" and of "Steuer" move towards and settle upon the form of definition we have adopted. Of "impôt" I can only say that I have not yet happened upon any French writer whose definition coincides with that I have adopted. 


\section{CHAPTER II.}

\section{The Development of Ideas About Taxation.}

THERE are two distinct plans on which this chapter might be written. On the one hand, we might describe the changes that have occurred in ideas of taxation from time to time, making groups of schools of thought and of periods, and building up a picture, chiefly composed of statements about the thinkers and writers of the different periods, with more or less critical comment. On the other hand, we might, with more trouble, collect as many as possible of the exact words of those who have at different times written of the principles of taxation, lay them out before us, draw inferences, if we will, or leave the evidence for each to draw his own inferences.

The first of these methods is the easier and pleasanter, both for the writer and for his readers. But it has the disadvantage that the reader is asked to accept a great deal on the authority of the writer. At its best, it is an admirable method for economising the reader's time and energy, and for providing him with a visualisation and a definite set of facts and opinions. At its worst it may be what in the world of belles-lettres is called " chatter about Harriet."

The second method is more wearisome, both to the writer and to the reader. It sacrifices a great deal of roundness, finality, and apparent completeness, in order to approximate more closely to the truth, and to keep open the door of revision. If it were completely followed out, it would demand that every phrase of every writer on the subject should be laid out in order. There may be a few writers ready to face such a task, but there would be very few readers. The method is not attempted here in all its completeness. 
It is followed as a method, and with what may fairly be claimed as sufficient completeness.

For convenience of treatment, more than for any other purpose, the evidence is divided into nine parts. The divisions are more or less arbitrary, and as we are adopting them mainly for convenience we need not spend time in justifying them. The works of Quesnay, Adam Smith, Ricardo, John Stuart Mill, Stanley Jevons, and Wagner, are sufficiently distinctive to be satisfactory landmarks. The quotations themselves will show that the divisions are, as we have said, chiefly of convenience. There is a great deal of overlapping, and it will not always follow that a writer of the nineteenth century is nearer to the position of the twentiethcentury economists than a writer of the eighteenth century. There is much atavism in the history of thought.

What we want to know is the result of human inquiries into the nature and basic principles of taxation, and if we traverse the ideas that have been held and expressed, it is chiefly to mark the general direction and trend of thought, that we may trace the movement that has brought us to our present position, and judge whether the evidence of the past confirms the belief of to-day. We want to see what foreign accretions have fallen away from the subject, and to be convinced that they were foreign to it, and not essential parts of it ; we want to confirm or re-set our conception of the just proportions of the different elements or principles of our subject, and see what is important, basal, vital, and what negligible, secondary, dispensable. All thought of value is for ultimate action, as life is for doing things. We examine past thought for the sake of future action.

The compilation of extracts is not the best possible (no compilation ever is), but it is the best possible under the circumstances, one of which is the fallibility of the compiler. But it should be complete enough and distributed enough for its immediate purpose.

We will say nothing, at this stage of the inquiry, concerning the fruitfulness or barrenness of the results. In any case, some review or summary of the course of thought must necessarily be included in an inquiry of this kind, and that 
holds whether we have begun with a preconceived theory, and seek its support, or have an open mind, like an unprinted page, ready for the impress of a verdict when all the evidence has been recited. Evidence is often so contradictory and confusing that it hinders rather than helps in the finding of a verdict: but that is not an argument for refusing to hear evidence. For the particular form in which the evidence is presented, we have already stated a reason.

Further, there is the question of bias in the selectingunconscious as well as conscious bias. This is probably a small matter, because there has been very little selection at all. Almost every quotable fragment on the principles of taxation that has come in the writer's way is inserted. There are sure to be omissions, perhaps serious omissions; but that is because of the limits of time and space, together with the general limitations under which the work has been done.

Apart altogether from its relation to this book, a series of opinions on the principles of taxation, presented in one view, has an interest of its own in the history of human thought, and an examination of these quotations may lead to inferences quite apart from those we may now draw.

\section{$\S$ I. EARLY NOTIONS.}

There is not a great deal to be garnered from ancient writings. The Greeks speculated freely on questions of government, but they troubled little over theories of taxation. Among the Roman writers too, though there is much about taxes and taxation, there is little theory. The Babylonians were a people likely to have arrived at definite practical ideas on the subject, but their tablets have revealed nothing yet of any particular interest.

Early taxes, like early laws, appear in a religious form, and under a theocracy the tithes and firstfruits are the only taxes known. In the description given in the book of Samuel, of the change from a theocracy to a monarchy, the 
representative of the theocracy very naturally objects that a king will claim taxes.

" He will take the tenth of your seed, and of your vineyards, and give them to his officers, and to his servants. . . . He will take the tenth of your sheep."

The rates that have been recorded vary from a twentieth to a quarter. In Hebrew history the rate is so uniformly a tenth that "tithe" has come to mean not only a tenth, but a tax of a tenth.

This attempt to fix a just fraction of the annual produce to be paid as tithe or tax, is almost the only contribution to a theory of taxation that the ancient religious laws afford. The evil effects of overtaxing are pointed out in several ancient codes, and the wisdom of a policy of moderation is pointed out, on very much the same basis as modern arguments of the folly of " killing the goose that lays the golden eggs." Josephus, who might have given us some significant comments, writing as he did with a knowledge of later practice and ideas, gives only a bare recital.

\section{(a) References in Ancient Sacred Books (dates uncertain).}

\section{Biblical References.}

Tithes are mentioned often in the Bible. ${ }^{1}$

The tithe includes, beyond the support of the priestly caste, something like a poor-rate. "At the end of three years thou shalt bring forth all the tithe of thine increase the same year, and shalt lay it up within thy gates; and the Levite (because he hath no part nor inheritance with thee), and the stranger, and the fatherless, and the widow, which are within thy gates, shall come, and shall eat and be satisfied " (Deut. xiv. 28-29). This recurs later. "When thou hast made an end of tithing all the tithes of thine increase

1 The references are these: Gen. xiv. 20; xxviii. 22; Lev. xxvii. $3 \mathrm{I}-33$; Num. xxiii. 2I-28; Deut. xii. 5-18; xiv. 22-29; xxvi. I2-I 4 ; 2 Chron. xxxi. 5, 12, 19; Neh. x. 37 ; xiii. 5 ; xii. 44 ; Amos iv. 4 ; Malachi iii. 8 ; Apocrypha, Tobit i. 7,8 ; New Testament, Matt. xxiii. 23 ; Luke xi. 42 ; xviii. 12 ; Hebrews vii. 5 . 
the third year, which is the year of tithing, and hast given it unto the Levite, the stranger, the fatherless, and the widow" (Deut. xxvi. I2). The Levites were not to have other possessions. "Thou shalt have no inheritance in their land" (Num. xviii. 20).

The term translated in our version by "tribute" seems to cover very much what is usually covered by that word ; and of course it falls under the general word "taxes." In the letter of complaint sent to the Persian king who is called Artaxerxes, " toll, tribute, and custom " are grouped as payments due to a sovereign lord (Ezra iv. I3, iv. 20 ; and again in Ezra vii. 24). The reference Ezra vii. 24, is interesting as an early example of the exemption of the clergy from taxes. "And I, even I, Artaxerxes the king, do make a decree. ... A And we certify you, that touching any of the priests and Levites, singers, porters, Nethinims, or ministers (Revised Version, "servants ") of this house of God, it shall not be lawful to impose toll, tribute, or custom upon them" (Ezra vii. 2I-24). The original unedited decree would have its own interest also.

The idea expressed in this book, that a tax is essentially a task, compulsory and without guarantee of definite equivalent, is illustrated by the Authorised Version and Revised Version renderings of Proverbs xii. 24. The former runs"The hand of the diligent shall bear rule: But the slothful shall be under tribute," and the latter,

"The hand of the diligent shall bear rule: But the slothful shall be put under taskwork."

The allusions to "tribute" are in Gen. xlix. I5; Num. xxxi. 28, 37, 38, 39, 40, 6I, 72 ; Deut. xvi. Io ; Josh. xvi. ro ; 2 Sam. xx. 24 ; I Kings iv. 6, and ix. 2I ; 2 Kings xxiii. 33 ; 2 Chron. viii. 8 and xvii. II ; Ezra iv. I3 and 20, vi. 8 , vii. 24 ; Neh. v. 4 ; Prov. xii. 24 ; Matt. xvii. 24, 25, and xxii. I7; Mark xii. I4; Luke xx. 22 and xxiii. 2 ; Rom. xiii. 6. 7. Taxes are referred to in 2 Kings xxiii. 35 ; Dan. xi. 2 ; Luke ii. I, 2 ; Acts v. 37.

\section{Apastamba.}

In the Âpastamba ("Sacred Laws of the Âryas ") a list 
of people exempt from taxes is given-learned Brâhmans, women, boys, students, those performing austerities, Sûdras who live by washing feet, blind, deaf, dumb and diseased persons. To support these is given in the Gautama as one of the duties of a king-Brâhmans, "those who are free from taxes," temporary students. The Gautama assigns one-tenth, one-eighth, or one-sixth of the produce to be paid to the king as a tax. "Some declare also on gold and cattle one-fiftieth." Whether property or income is meant is not always clear. Merchants are to pay one-twentieth, and sellers of fruits, flowers, etc., one-sixtieth. It proceeds :

"For it is the duty (of the king) to protect (the taxpayers)

"But to (the collection of) these (taxes) he shall always pay particular attention. He shall live on the surplus. Each artizan shall do monthly one (day's) work."

\section{Vasishtha.}

The Vasishtha says:-

"But a king who rules in accordance with the sacred law may take the sixth part of the wealth (of his subjects) - except from Brâhmans."

Later in the same writing come these passages:-

" He who swims with his arms [i.e. to avoid a toll at a ferry] shall pay one hundred times.

"No taxes shall be paid on the usufruct of rivers, dry grass, forests, (places of) combustion, and mountains ; or those who draw their subsistence from them may pay.

"But he shall take a monthly tax from artisans."

One-tenth of the produce is given as the annual levy in the "Shih King"-Ode 7 of the Sixth Decade.

"Bright are the extensive fields, a tenth of whose produce is annually levied."

\section{Laws of Manu.}

In the Laws of Manu (VIII. 398) the proportion to be paid in taxes is put at one-twentieth.

" Let the king take one-twentieth of that which men well acquainted with the settlement of tolls and duties, skilful in 
(estimating) all kinds of merchandise, may fix as the value for each saleable commodity."

There are laws immediately following directing confiscation of the whole property of a trader who exports (" out of greed ") any good of which the king has a monopoly; an eightfold fine for the evasion of tolls and duties; a weekly fixing of prices by the king; an examination of weights and measures twice a year.

People exempt from taxes are mentioned :-

"a blind man, an idiot, one who moves with the help of a board (a cripple), a man full seventy years old, and he who confers benefits on Srotriyas." -VIII. 394 .

"Having well considered (the rates of) purchase and sale, the road, food and condiments, the charges of securing the goods, let the king make the traders pay duty. After due consideration the king shall always fix in his realm the duties and taxes in such a manner that both he himself and the man who does the work receive (due ?) award. As the leech, the calf, and the bee take their food little by little, even so must the king draw from his realm moderate annual taxes."-VII. I27-129.

A list of rates follows, a fiftieth of cattle and gold, an eighth, sixth or twelfth of crops, a sixth of other (specified) goods.

"Let him (the king) not cut his own root, nor the root of other (men) by excessive greed."-VII. I30.

The same lesson is taught later by another figure.

"As the sun during eight months draws up water with his rays, even so let him gradually draw his taxes from his kingdom." IX. 305 .

The proportion of the produce to be taken in taxes is extended for particular occasions to a quarter :-

"A king who in times of distress takes even the fourth part (of crops) is free from guilt, if he protects his subjects to the best of his ability." $-\mathrm{X}$. I20.

\section{Lî Kî.}

The Lî̀ Kî, an ancient sacred book of China, declares 
that " anciently . . . only three days' labour was required (by the State) from the people in the course of a year." Speaking of the "regular contributions to the government," it says that these are determined " by the distance of the territories and the nature of their several productions." The object is " to provide what is necessary for the suburban sacrifices and those in the ancestral temple. No private considerations are allowed to have place in this."

\section{( $\beta$ ) Ancient Greece and Rome.}

The Greek writers, who have given us so much, and whose works on politics are still so widely studied, left nothing of any importance on the principles of taxation, beyond some excellent but vague advice that people, and especially poor people, should not be too heavily taxed. The chief reason for the omission is that state-revenues were not largely supplied from taxes, but from State property.

We have, however, some interesting passages: one from Herodotus, laying down the doctrine of taxation according to faculty; one from Plato, where the State is empowered to tax according to property or to income, as the State officials may decide, and apparently in each case on its merits ; and a famous passage from Julius Pollux, written in the Roman period, but concerning the Greek States. It is commented upon below. The quotation from Tacitus shows a clear understanding of an economic phenomenon concerning the effects of the remission of taxes that is not universal among the citizens-to say nothing of the legislators-of modern states. We get a definite statement of Proportionalism from Dionysius Halicarnassus, to set against the Progressive system of Solon (Pollux) ; beginning thus a contest that is not yet ended.

Herodotus (c. B.C. 484-B.c. 420).

"The same authority informed me that Seostris made a regular distribution of the lands of Egypt. He assigned to each Egyptian a square piece of ground; and his revenues were drawn from the rent which every individual annually paid him. Whoever was a sufferer by the inundation of the Nile, was permitted to make the king acquainted with his loss. Certain 
officers were appointed to inquire into the particulars of the injury, that no man might be taxed beyond his ability." - Herodotus, Bk. II, "Euterpe," I09 (circa B.C. 420).

Pseudo-Xenophon (c. B.C. 350).

"In the proposals I offer, there is only one new thing-that as private individuals have a constant revenue coming in from slaves whom they hire out to work in the mines; so the State should imitate their example, and purchase as many slaves, to be used in the same way, as will treble the number of the citizens." - "Discourse upon Improving the Revenue of Athens" (attributed to Xenophon, but probably later-circa B.C. 350).

Plato (B.C. 427-B.C. 347).

"With a view to taxation, for various reasons, every man ought to have had his property valued: and the tribesmen should likewise bring a register of the yearly produce to the wardens of the country, that in this way there may be two valuations ; and the public officers may use annually whichever on consideration they deem the best, whether they prefer to take a certain portion of the whole value, or of the annual revenue, after subtracting what is paid to the common tables."-Plato, "Laws," XII. 955, Jowett's edition (circa B.c. 300).

Marcus Tullius Cicero (B.C. Io6-43).

"The second duty of the governors of a State is to see that the people are not forced to pay taxes ... . but if under such circumstances [as those of war or an empty treasury, which Tully cites] recourse must be had to such an expedient ... then due care must be taken to inform the people of it."-De Officiis, II. xxi. (в.c. 50-40).

\section{Livy (B.C. $59-$ I7 A.D.).}

"The senate at this tim therefore took steps to conciliate the commons. Their fir:t care was for the markets, and some were sent to the Volsciari, others to Cumæ, to buy corn. As the price of salt had risen to an extravagant height, its sale was taken from private hands, and put entirely under governmental control. Moreover, the commons were exempted from port dues and taxes, so that the public expenses might fall upon the rich, who were able to support the burden: the education of their own children being a sufficient tax upon the poor."-Titus Livius, Bk. II. ix. (circa B.c. 27).

[The time referred to in the passage would be about B.C. 500.] 
Dionysius Halicarnassus (fl. circa B.c. 60-B.C. 5).

"It is very just, I think, and very much to the public good, that such as have large fortunes should pay largely, and such as have less in proportion."-Dionysius Halicarnassus, on the Census, Lib. IV. p. 215, Edition Syllburg (circa B.c. I2).

\section{Pliny $(6 I-I I 5)$.}

"The needs of the Empire gave rise to many imposts (vectigalia) for the common benefit, but burdensome to individuals. Such was the tax of the twentieth (vicesima), light to foreign heirs (extraneis) but grievous to heirs of the family (domesticis). . . . It was most excellent in you, Cæsar, not to suffer taxes to be laid upon parents' tears. ... The hardship has become a satisfaction, the burden a gift. The heir desires to pay the twentieth."-Pliny, "Panegyricus," 37-40 (circa IIr).

\section{Tacitus (Ist Century).}

"Moreover, the duty of four in the hundred upon the sale of slaves was remitted, in appearance rather than effect; for, as the seller was obliged to pay it, it formed an additional component of the price to purchasers." -Tacitus, "Annals," XIII. 3I (circa IIO A.D.).

\section{Pollux (2nd Century).}

"They were called pentacosiomedimni because they realised an annual income of 500 medimni of wet or dry produce; these paid $£ 240$ (a talent) into the public treasury. But a man who could keep a horse seems to have been rated as a knight. Men of this class realised 300 medimni and paid $£$ r20. Men who realized 200 medimni and who could keep a yoke of oxen paid £40. Members of the labouring class paid nothing and were ineligible for any public office."-Pollux, " Onomastikon," VIII. X. I30 (circa I50 A.D.).

The last sentence implies the definite principle that no share of government is to be given to a class that does not pay taxes : a forerunner of later (but converse) dicta connecting taxation with representation.

This passage is loosely paraphrased by Montesquieu, in "L'Esprit des Lois" (XIII. vii.) and his paraphrase has since been quoted or alluded to by many writers, especially those who are eager advocates of progressive taxation. For besides the principle already mentioned, it contains two other doctrines of the science of public finance-the 
exemption of a minimum from taxation, and a progressive scale.

All progressive scales have features of interest, and it is worth while to set out the scale given. A medimnus may be taken as I2 gallons. Reckoning I2 gallons, and with the usual computation of $£ 240$ for a talent we get this scale :-

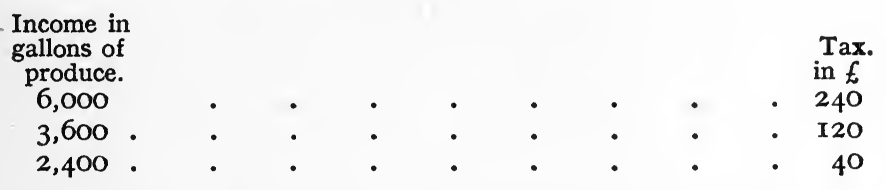

Keeping the same scale, and expressing incomes as well as taxes in money, we could represent this in modern form as an income tax of this nature-

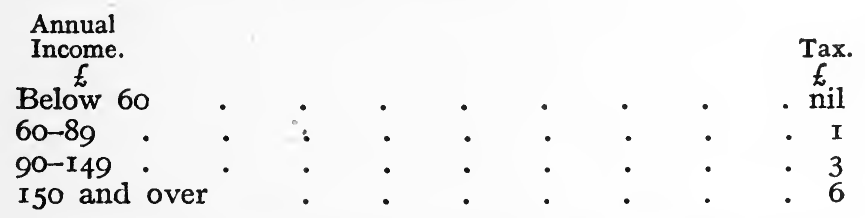

Or, bringing the exemption limit to the English $£$ I60, for comparison,-

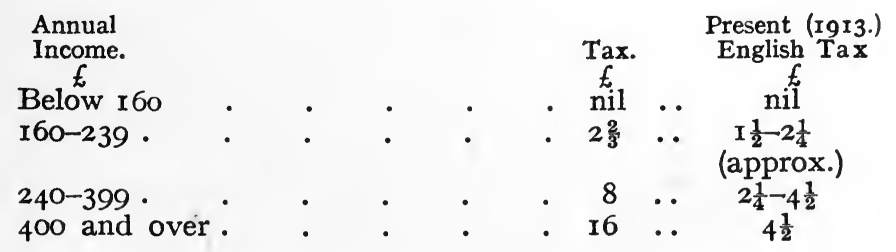

The Athenian graduation was decidedly " steep."

Professor Seligman cites another progressive scale " during the archonship of Nausinicus (B.C. 380), though the tax may have been levied occasionally in the interval. By this time the property assessed included not only real estate but personalty. There were still four classes, but with no exemption for the lowest class and with a graduation in the tax. While there is some doubt as to the exact figures, it seems probable that the tax was now a progressive income 
tax.- "Progressive Taxation," p. I4 (I894. American Economic Association).

\section{§ 2. THE BLANK PERIOD.}

If we pass over a period of about a thousand years in a breath (from the sixth century to the sixteenth), and give it "The Blank Period " for a title, we do not thereby make claim that it is utterly and completely blank for us, but that it is without significance. The utterances that we have cited from earlier times were indeed occasional and sporadic, but they have influenced successive inquirers, and their influence is by no means exhausted. Advocates of progressive taxation still quote Pollux on the laws of Solon, and enthusiasts for proportionalism might retort by quoting the Codex Justinianus. But whatever notes on the theory of taxation may lie hidden in the many volumes of the mediæval writers, whatever significant things may have been said, they have remained hidden and apart from the general movement of thought that came later. There is no doubt something for future seekers to bring to lightperhaps much, though that is unlikely. But whatever of interest may attach to discoveries of early anticipations of modern knowledge, there must be drawn a clear line between those that have remained obscure, and those that have affected the body of human thought, and its movement. It would be intensely interesting to discover, on some cuneiform tablet, an accurate exposition of the modern law of rent, or a detailed account of the marginal-utility theory of value; but these things would still be as much of modern discovery as they are now. Nor would any one be likely, in such a case, to doubt that they had been quite independently re-discovered. But it is not in such clearly-marked examples that the confusion arises. More generally it is some more or less identical adumbration, in some more or less obscure work, that comes to light, and usually an unnecessary discussion arises about priority of discovery. The view we are taking is not that foreshadowings are of no importance, but that where continuity has been lost, 
there is a corresponding loss of importance in relation to human thought, proportionate to the extent of the break.

This is a very insufficient excuse for the absence of quotations in this section, but we submit it as a proper setting forth of the relative significance of the break. An excellent example of the kind of inquiry that has been pursued may be found in an edition of Aristotle's "Ethics" and "Politics" issued by Dr. J. Gillies in I804. (This is the second edition.) In a note on pp. 376-377 (vol. I. " Ethics ") Dr. Gillies says :-

"The exchangeable value of commodities, according to Aristotle, is always relative to the labour requisite for producing them ; and the quantity of productive labour is exactly measured by the work or production in which this labour is fixed or embodied."-Metaph. 1. IX. c. viii. p. 939.

I must confess I have not been able to find anything in the reference given to justify the statement, nor can I find it anywhere in Aristotle. ${ }^{1}$ However, granted the accuracy of Dr. Gillies' rendering of Aristotle's view, consider what inquiries or discussions might follow. It might be stated that Karl Marx took the Quantity of Labour Theory of Value from Aristotle; or that the theory could be traced through a line of writers to Aristotle; or that it had been held, in more or less vague forms, by many thinkers (the most probable explanation); or that it was independently arrived at by Marx, Aristotle, and perhaps others. What happens is that two or more of these statements are confused into one, and the significance of greater or less exactitude, as well as the significance of continuity in human thought, is lost. We may finally be asked to take the side of the ill-used Aristotle, or of the maligned Marx. There may be, in central Patagonia, some unknown tribe that has used a rude steam-engine for centuries; but if so, it bears no relation to the work of Watt or Papin, or even Hero of Alexandria.

In the few citations made, it is curious to note the declaration of proportionalism in the European code, side by side

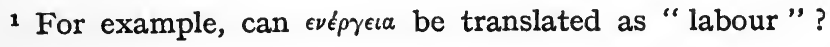


with what Dr. Chen Huan-Chang says of the Confucians' preference for progressive taxation.

\section{Codex Justinianus.}

"All public charges should be made in proportion to fortunes."- "Codex Justinianus" (529).

\section{K'ung Ying-ta (574-648 A.D.).}

"The pitcher has been exhausted. It is the shame of the jar."-The "Canon of Poetry."

"It means that this is the shame of the drinker who takes charge of the jar. The large jar is like the rich and large family ; the small pitcher, the small and poor family. If both the jar and the pitcher are arranged for drinking, one should drink more from the jar and less from the pitcher until both are exhausted; this is the principle of equality. It is just the same principle as that of taxation: when both the rich and the poor are taxed, in money as well as in labour, one should tax the rich more and the poor less, up to the point that both can bear the burden; this is also the principle of equality." $-\mathrm{K}$ 'ung Ying-ta (574-648 A.D.).

Dr. Chen Huan-Chang says : "The first principle of taxation is equality - a tax must be equally imposed on every one and in whatever place. It is illustrated in a poem of the "Canon of Poetry.' . . . The second principle of taxation is universality - a tax must reach everybody. This principle is illustrated by a poem of the "Canon of Poetry.' . . ."-Dr. Chen Huan-Chang, "The Economic Principles of Confucius and his School," Columbia University (I9II).

"According to Chêng (Chêng Hsüan, I27-200, A.D., ' the chief figure among all the Confucians of the Han dynasty') and $K^{\prime}$ 'ung (K'ung Ying-ta, 574-648 A.D.) a tax should be progressive rather than proportional, because it should put the rich and poor on the same footing in accordance with their ability." -Ibid. p. 63I.

\section{Lu Chih (8th Century).}

"To create offices and to establish government is for the end of nourishing the people. To tax the people and to get revenue is for the means of supporting the government. A wise ruler does not increase the means at the expense of the end. Therefore, he must first pay his attention to the business of the people, and give them a full chance for their economic activities. $\mathrm{He}$ must first enrich every family, and then collect the surplus of their income."-Lu Chih, "General Political History," ch. ccxxxiv. (794 A.D.). 


\section{§ 3. The Formative Period.}

In the seventeenth century, and in the early part of the eighteenth, the science of public finance took definite form. The period that lies, let us say, between the birth of Hobbes and the death of Montesquieu, may be taken to mark the first definite steps in the movement of inquiry into questions of public finance-the first steps, that is, in the march of continuous research. We pass away, during this period, from the occasional pioneers to the advancing settlers. Philosophic thinkers, like Locke and Montesquieu and practically-minded men like Vauban and Petty, prepared the way for the Physiocrats, as these did for Adam Smith and the Ricardians, and they for Mill, Jevons, and the moderns. There was thought on questions of taxation before this period, as indeed we have seen : but not a body of thought. We get an exposition of the Benefit Theory and a definition of equality from Hobbes; a system of exemption from Harington, and the "Leave Them As You Find Them" doctrine from Petty; the maxims of Certainty and of Equity outlined by Boisguillebert, and the Proportional measure of equity adopted by Vauban; the possibility of a voluntary tax put forward by Decker, and the case for Graduation urged by Montesquieu. And we get, in Locke, the basis on which the Physiocrats of the next period built their system of the Single Tax. We move from sporadic thinkers to schools of thought; from now advance becomes continuous.

Writers of this period (in the domain of Economics), have been classed as Mercantilists (e.g., Petty), or as Kameralists (e.g., Justi), the English term roughly corresponding to the German or Continental usage of "Kameralist." But the terms are not identical.

\section{J. Bodin (I530-I596).}

"If the sinews of the Republic are its finances, as an ancient orator said, it is well to know them properly, which can be done under three heads : first, the honest means of gathering money, secondly, its employment to the profit and honour of the Republic, and thirdly, the saving and keeping of a part of it against need. . . . It is necessary then for every Republic to see to it 
that its finances are built up on a sure and lasting foundation. Now there are seven methods in general for building up a public treasure, including all that can be imagined. The first is from the domain (dommaine) of the Republic ; the second, from conquests of enemies ; the third, the gifts of friends ; the fourth, pensions or tributes from allies; the fifth, from traffic; the sixth, from merchants who bring or take away goods; the seventh, from taxes (imposts) on the citizens.

"The seventh means is upon the subjects, and should never be resorted to unless all the others fail, and that necessity calls for support of the Republic, in which cases since the care (tuition) and defence of individuals depends on the preservation of the state (public), it is right that every one should attend to it: then charges and impositions on the subjects are very just, for there is nothing juster than necessity, as an ancient Roman senator said. Nevertheless, that the extraordinary burden imposed in war-time should not continue during peace, it is expedient to proceed by borrowing. Besides, the money is more easily found, when the lender hopes to receive both thanks and his money again. ...

"There are three kinds of impositions (deniers) levied on the subjects-ordinary, extraordinary, and a third kind containing both the others, and called casual. Of which charges and impositions the most ancient are reputed domains (dommaines) like customs (l'imposition foraine); others ordinary, like the taille; the last are extraordinary, which the Latins called temerarium tributum, as subsidies on free towns and privileged persons, tenths, and charitable gifts equivalent to tenths, levied by commission. ... A And generally the great towns put their burden on the plains, and the richer peasants on the poorer. . . . Now to remedy this inconvenience, the ancients wisely ordered and put in practice, that charges should be real, and not personal, as is done in Languedoc, and for some years also in Provence, by provision of the law, that rich and poor, noble and plebeian, priest and labourer, should pay the charge upon their taxable (taillable) land: the law exempts neither pontiff nor noble. . . . If then necessity causes the levy of an extraordinary impost, it should be such that each shall pay his part, as in the duties on salt, wine, and other like things." - J. Bodin, "Les Six Livres de la République," VI. ii. (From the French edition of I580. The book appeared, in French, in 1576 . In $x_{586}$ the larger Latin edition was published. An English version, called "The Commonweale," translated from the two issues, was made in I606).

Bacon (I560-I626).

"Treasure in a state is more or less serviceable, as the hands 
are in which the wealth chiefly resteth ... that the wealth of the subject be rather in many hands than in few . . . for it is not the abundance of treasure in the subject's hands that can make sudden supply of the want of a state. . . A Again, whereever the wealth of the subject is engrossed into few hands, it is not possible it should be so respondent and yielding to payments and contributions for the public."-Francis Bacon, "Of the True Greatness of the Kingdom of Britain " (written circa I608, and first published I634).

\section{Montchrétien (I576-I62I).}

"You have not, Sire, any better means of settling the just grievances of the poor against the rich, who, like the strongest parts of the body relieving themselves at.the expense of the weakest, throw their just burdens upon those who are already crushed. Thus can you put an end to all rumours, quieten all murmurs, still all movements, lessen all causes of tumult, for equal intemperateness (intemperie) makes no grievance, but if unequal, makes a grievance as great as the inequality; you can thus cut the root of the greater part of the lawsuits in your Cours des Aides, abolish the disputes of many officers, the licences and favours of the elect, of assessors, collectors and others, who distribute and equalise the taille, subsidies, and imposts, because all such differences would easily be settled by the rent-rolls.

All that can be put before you to prevent Your Majesty from striking this great blow, is that it is too hard to make known the poverty of some, and that the wealth of others would be exposed to envy. On the contrary, envy would cease against those who are believed to be rich and are not, mockery (would cease) against those held to be poor who are rich."-Antoyne de Montchrétien, "Traicté de l'ÉEconomie Politique" (I6I5).

\section{La Mothe de Vayer (I588-I672).}

"Nor is it sufficient that sovereigns abstain from violent oppressions; to make just and reasonable impositions (impositions) they must observe many things, without which their government will not be happy, nor their finances well regulated.

" First, then, they must manage so that the greater part of the levies that they demand from the people, may be like the vapours that rise from the ground, which, after thickening into clouds, fall again to earth, returning whence they came. For if the gold and silver that are taken from individuals are kept in the Treasury in too great a mass, they will soon reduce the kingdom to extreme poverty, and the Treasury will be, as one of the ancients put it, like the spleen in the human body, which becomes hectic as soon as it grows over large. 
" They must also take care that the impositions (impositions) are made in geometrical rather than in arithmetical proportions, so that all classes in the State will contribute to it, and each one according to his abilities (forces), and according as considerations of good government, of which the Italians talk so much, will permit. . . I I know well that in the matter of subsidies, all equally complain, and whoever has a fine head of hair cries out no less loudly than he that is bald, if but a single hair is taken out. But it is none the less true that those who are full-blooded can better bear copious and frequent bleedings than those of another temperament." [The writer does not mention any other than these two of the "many things" which he says sovereigns must observe.]-François de la Mothe le Vayer, "De l'Instruction de Monseigneur Le Dauphin,” I. Des Finances (I640).

\section{Hobbes (I588-I679).}

Hobbes defines taxes as " the wages due to them that hold the public sword " ("Leviathan," ii. 30). In the same chapter he argues for equal taxes, and for taxes upon consumption.

"To equal justice apertaineth also the equal imposition of taxes; the equality whereof dependeth not on the equality of riches, but on the equality of the debt that every man oweth to the commonwealth for his defence. It is not enough for a man to labour for the maintenance of his life ; but also to fight, if need be, for the securing of his labour. They must either do as the Jews did after the return from captivity, in re-edifying the Temple, build with one hand, and hold the sword in the other ; or else they must hire others to fight for them. For the impositions that are laid on the people by the sovereign power, are nothing else but the wages, due to them that hold the public sword, to defend private men in the exercise of their several trades, and callings. Seeing then that the benefit that every one receiveth thereby, is the enjoyment of life, which is equally dear to poor and rich; the debt which a poor man oweth them that defend his life, is the same which a rich man oweth for the defence of his ; saving that the rich, who have the service of the poor, may be debtors not only for their own persons, but for many more. Which considered, the equality of imposition consisteth rather in the equality of that which is consumed, than of the riches of the persons that consume the same. For what reason is there, that he which laboureth much, and sparing the fruits of his labour, should be more charged, than he that living idly, getteth little, and spendeth all he gets; seeing the one hath no more protection from the commonwealth than the other? But when the impositions are laid upon those things which men consume, 
every man payeth equally for what he useth : nor is the commonwealth defrauded of the luxurious waste of private men." "Leviathan," II. 30 (I65I).

Here we have a logical application of the "benefit" theory. Since "the benefit that every one receiveth," is the same, i.e., "the enjoyment of life," payments in taxes should be equal. This is to mean that the rich " who have the service of the poor," are to pay for those poor. Since the poor owe " the enjoyment of life " to the commonwealth, and not to the rich who have their services, it follows that the poor should pay their equal shares to the commonwealth. This they do through the medium of the rich whom they serve. The rich pay the taxes of the poor in the same sense as an importer of tobacco pays the duty for the customers.

Hobbes gives practically the same definition in the "Philosophical Rudiments" ("Of Dominion," xii. 9), and here also he speaks of equality of taxation, on the basis that "they who equally share in the peace, should also pay an equal part, either by contributing their monies or their labours to the commonweal." He explains the idea of equality more fully here.

"Now in this place we understand an equality, not of money, but of burthen; that is to say, an equality of reason between the burthens and the benefits. For although all equally enjoy peace, yet the benefits springing from them are not equal to all ; for some get greater possessions, others less; and again, some consume less, others more. It may therefore be demanded, whether subjects ought to contribute to the public according to the rate of what they gain, or of what they spend: that is to say, whether the persons must be taxed, so as to pay contribution according to their wealth; or the goods themselves, that every man contribute according to what he spends. But if we consider, where monies are raised according to wealth, there they who have made equal gain, have not equal possessions, because that one preserves what he hath got by frugality, another wastes it by luxury, and therefore equally rejoicing in the benefit of peace, they do not equally sustain the burthens of the commonweal : and on the other side, where the goods themselves are taxed, there every man, while he spends his private goods, in the very act of consuming them he undiscernably pays part due to the commonweal, according to, not what he hath, but what by the benefit of the realm he hath had: it is no more 
to be doubted, but that the former way of commanding monies is against equity, and therefore against the duty of rulers ; the latter is agreeable to reason, and the exercise of their authority.'

Hobbes is considering here whether " the persons must be taxed or the goods themselves," and finds that to tax persons, that is to say, as he puts it, to tax the public according to the rate of what they gain, is against equity. Yet even " where the goods themselves are taxed," as he desires, he expresses the payment as made by the person concerned, who undiscernably pays part due to the commonweal." Still, it is quite clear that Hobbes holds taxing persons and taxing goods to be separate and opposite things. If people pay according to their expenditures the goods themselves are taxed, and the result is an equality of burthens.

In "De Corpore Politico" (I650) we have another exposition of the same doctrine.

"Secondly, to divide the burthens and the charges of the commonwealth proportionably. Now there is a proportionably to every man's ability, and there is a proportionably to his benefit by commonwealth : and this latter is it, which is according to the law of nature. For the burdens of the commonwealth being the price that we pay for the benefit thereof, they ought to be measured thereby. And there is no reason, when two men equally enjoying, by the benefit of the commonwealth, their peace and liberty, to use their industry to get their livings, whereof one spareth, and layeth up somewhat, the other spendeth all he gets, why they should not equally contribute to the common charge. That seemeth therefore to be the most equal way of dividing the burden of public charge, when every man shall contribute according to what he gets. And this is then done, when men pay the commonwealth's part in the payments they make for their own provision. And this seemeth not only most equal, but also least sensible [ $=$ felt], and least to trouble the mind of them that pay it. For there is nothing so aggravateth the grief of parting with money to the public, as to think they are over-rated, and that their neighbours whom they envy, do thereupon insult over them, and this disposeth them to resistance, and, after that such resistance hath produced a mischief, to rebellion."- " De Corpore Politico," II. 9, 5.

He speaks of taxes paid the sovereign returning again to the people. 
"The greatest sums that ever were levied, comparing the value of money, as it was at that time, with what it is now, were levied by King Edward II and King Henry V ; kings in whom we glory now, and think their actions great ornaments to the English history. Lastly, as to the enriching now and then a favourite, it is neither sensible to the kingdom, nor is any treasure thereby conveyed out of the realm, but so spent as it falls down again upon the common people."- " A Dialogue between a Philosopher and a Student of the Common Laws of England."

To this the student meekly replies. "I know not what to say." "Leviathan " was published in I65I, "De Corpore Politico" in I650.

Harington ( $16 \mathrm{II}-\mathrm{x} 677$ ).

In Harington's " Oceana," taxation was to be employed at first to aid in increasing population.

"But if a man has ten children living he shall pay no taxes; if he has five living, he shall pay but half taxes; if he has bin married three years, or be above twenty-five years of age, and has no Child or Children lawfully begotten, he shall pay double taxes."

Later, taxes disappeared in Oceana, for " the Army was disbanded, but the Taxes continu'd at thirty thousand pounds a month, for three years and a half. By which means a piece of Artillery was planted, and a portion of land to the value of 50 l. a year purchased for the maintenance of the Games, and of the Prize arms for ever, in each Hundred."

In the eleventh year of the Commonwealth, the excise also expired, but, taxes being altogether taken off, the excise was renewed for ten years, being " of no great burden," though the Commonwealth had now a sufficient revenue from its Capital.

"Oceana" was published in 1656 .

Petty (I623-I687).

"It is generally allowed by all, that men should contribute to the Publick Charge but according to the share and interest they have in the Publick Peace; that is, according to their Estates or Riches: now there are two sorts of Riches, one actual, and the other potential. A man is actually and truly 
rich according to what he eateth, drinketh, weareth, or in any other way really and actually enjoyeth; others are but potentially or imaginatively rich, who though they have power overmuch, make little use of it; these being rather Stewards and Exchangers for the other sort, than owners for themselves.

"Concluding therefore that every man ought to contribute according to what he taketh to himself, and actually enjoyeth. ...

"Now the reasons for Excise are these, viz.-

" First, the Natural Justice that every man should pay according to what he actually enjoyeth....

" Secondly, This Tax if it be not farmed, but regularly collected, engages to thrift, the onely way to enrich a Nation.

"Thirdly, No man payes double or twice for the same thing, forasmuch as nothing can be spent but once...

"Fifthly, [Petty gives no "Fourthly"] By this way an excellent account may be taken of the Wealth, Growth, Trade, and Strength of the Nation at all times. ...

"I should here adde the manner of Collecting it, but I refer this to the practice of Holland. . . "-Sir William Petty, "A Treatise of Taxes and Contributions," Chap. xv. "Of Excize" (I662).

"The first way of providing for the Publick Charge, is the excinding or setting apart of a portion of the Territory, in the nature of Crown Lands.

"The second is taking away the same proportion of the Rents of all Lands." -Ibid. The Index.

"Let the Tax be never so great, if it be proportionable unto all, then no man suffers the loss of any Riches by it. For men (as we said but now) if the Estates of them were all either halfed or doubled, would in both cases remain equally rich."-Ibid., Chap. iii.

\section{Pufendorf (I632-I694).}

"A wise prince, however, will comply with the querulous temper of the people, in having the taxes (tributa) collected so as to cause as little disturbance and ill-feeling as possible.

" But in imposing taxes (tributa) or other burdens (onera) there should be no cause of complaint given. This will arise, if the burdens of the state are laid unequally on the citizens. ... To find out in what equality consists, we must bear in mind that 
we are not considering equality of money, but of burdens. Thus it is not necessary that all should pay equal amounts in money, but that no man should be burdened more than another. 'This is secured, if the ratios are the same, between burden of tax and benefits of peace. For although all equally enjoy peace, they do not derive equal advantages from it. Some get more, and some less, some consume more, and some less, than others. . . Hence all levies at extraordinary times should be made according to a valuation (censum). And since the State defends the life of every man, a thing equally dear to the rich and to the poor, all are equally to be called upon for war-service, and no less equally to pay a moderate tax (tributum), such as a poll-tax (capitatio), where the rich pay no more than the poor. But since it is owing to the State that the citizens have the benefit and opportunity of increasing their possessions by their industry, the difficulty is to settle how the burden is to be imposed conformably? It appears to be most convenient that people should be taxed (taxare) according to what they consume, rather than according to what they get (lucratur). For men generally spend according to their incomes." -Baron S. Pufendorf, "De Jure Naturæ et Gentium," Bk. VIII. ch. v. v. vi. (I672).

(The last sentence is not in the first edition of 1672 , though a passage occurs (given also in the later edition), to the same effect. Both passages are in the later issue of 1675 , translated into English by Carew, and published in I749.)

\section{Locke (I632-I704).}

" This, by the way, if well considered, might let us see, that taxes, however contrived, and out of whose hand soever immediately taken, do, in a country, where their great fund is in land, for the most part terminate upon land. Whatsoever the people is chiefly maintained by, that the government supports itself on ; nay, perhaps it will be found, that those taxes which seem least to affect land, will most surely of all others fall the rents. ... Struggle and contrive as you will, lay your taxes as you please, the traders will shift it off from their own gain. . . ."John Locke, "Consequences of the Lowering of Interest, and Raising the Value of Money" (I6gr).

"It is true governments cannot be supported without great charge, and it is fit every one who enjoys his share of the protection should pay out of his estate his proportion for the maintenance of it."-John Locke, "Two Treatises of Civil Government," II. I40 (I689). 


\section{Boisguillebert (I646-I7I4).}

"It being supposed, then, that the king wishes and intends the taille to be levied henceforth justly - that is, that the rich should pay as rich and the poor as poor."- " Le Détail de la France," III., by Pierre le Pesant, sieur de Boisguillebert (I6g6I697).

In the "Factum de la France," written ten years after " Le Détail," he sets out three vices of the Taille, giving us some conception of his general view of taxation.

" - the first, its uncertainty, as much in the assessment of parishes as on the heads of individuals; the second, its injustice, being high and violent, not in relation to the ability (faculté) of the contributors, which nevertheless is the spirit of the institution, as in all countries of the earth, even the lowest and most barbarous, but in regard only to the degree of protection or of importance that a man might have to defend himself; and the third finally, the collection of this tax (impot : but he is speaking of the taille only in this case) - of which, because of bad distribution, a great part remains as a loss to those charged with its unhappy recovery; and as each one goes to it in his turn, it comes to every one, consequently, to be ruined in turn." - " Factum de la France," V. (I707).

Vauban (I633-I707).

"Fundamental Maxims-

"I. It is known and recognised, wherever in the world civilised peoples exist that all the subjects of a State have need of its protection, without which they could not exist.

"II. The prince, chief and sovereign of the State, cannot give this protection, if his subjects do not furnish him with the means; whence it follows,

"III. That a State cannot support itself, if the subjects do not support it. Now, this support includes all the needs of the State, to which, consequently, all the subjects are obliged to contribute.

"From this necessity, there follows: First, a natural obligation of subjects of every condition to contribute in proportion to their income or their industry, without any of them being able reasonably to escape it ;

"Secondly, that it is sufficient to authorise this right, to be a subject of the State;

Thirdly, that every privilege which tends to exemption from this contribution is unjust and an abuse, and can only prevail to the prejudice of the public." - "Introductory Passages of the "Dîme Royale" " (I707). 
"As all those who form part of a State have need of its protection to subsist, and to maintain themselves, each in his natural situation, it is reasonable that all should contribute, according to their incomes: that is the intention of the maxims placed at the beginning of this memoir. Nothing is so unjust as to exempt from this contribution those who are best able to pay, to throw the burden on those less able, who succumb under a burden that would have been light, had it been carried by all in proportion to their powers; whence it follows that every exemption on this account is a disorder that ought to be corrected. After much reflection and experience it has appeared to me that the king has a sure and efficacious means of remedying all these evils, present and to come.

"This means consists in making each contribute to the needs of the State according to his income, but easily, by a proportion of which no one can complain, because it would be so spread and distributed, that although it would be equally borne by all individuals, from the highest to the lowest, no one would be overcharged, because no one would bear it except in proportion to his income." - "Dîme Royale," Première Partie (I707).

Vauban thought it necessary, not only to say, but to repeat and italicise, "that kings have a real and very essential interest in not overburdening their people so as to deprive them of necessities." He quotes a remark of Henri le Grand, when in a time of his need a new tax was suggested : - "It was good not to do always as much as one could." Bois-Guillebert, his contemporary, calls attention to the same truism by an ironic statement of the reverse.

"Although it has been quite sufficiently shown that it is to the king's interest to ruin consumption - " "Le Détail de la France," XXI.

Decker (I679-I749).

Sir Matthew Decker's "Essay on the Causes of the Decline of the Foreign Trade " etc., was published in I749, and the title-page bears the words "Begun in the year I739." While discussing taxes in this Essay, he says of the salt-tax.

"This is collected with the greatest expence of any, in proportion to its amount, consequently is more grievous to the Subject, and less beneficial to the Government: Is attended with more pernicious consequences than any single Tax, for it has an universal influence on all Manufactures. . . .' 
His idea of making taxation voluntary is outlined a few pages further on-

"Several Authors have thought Excises and Land-Taxes to be the most equal Methods of raising Supplies, but, if strictly attended to, they will appear far otherwise ; any thing positive and involuntary cannot avoid Oppression, which Humanity should make the first Consideration in raising money from the People, and good Policy the second, in order to prevent Evasion and Fraud, the Children of Oppression.

"A working Bachelor pays the Excise, etc., on his own Shoes only.

"A working Married-Man does the same for himself, the same for his Wife, the same for his five sons, the same for his five daughters; twelve in family.

"A Landed Bachelor of I,0oo $l$. per Annum when the Land Tax is at $2 s$., pays roo $l$.

"A Landed Married-Man of the same Estate does the same, having a Wife and ten Children."

On a like ground he condemns a "Poll Tax," such as that of the States of Holland, issued in I742. (A tax of 6 florins on an income of 600 florins, and in a scale of which a few items may be quoted here.

Income.

(Figures all in Florins.)

Tax.

\begin{tabular}{|c|c|c|c|c|c|c|c|c|}
\hline $\mathrm{I}, \mathrm{OOO}$ & • & - & • & • & - & . & • & . \\
\hline 2,000 & • & • & . & . & . & . & . & • \\
\hline 4,000 & • & - & - & • & . & • & • & - \\
\hline 8,000 & - & - & - & • & . & - & . & • \\
\hline 12,000 & . & . & . & . & . & . & . & . \\
\hline
\end{tabular}

and so on, increasing at the Foot of 50 florins, for every 2,000 florins Income.)

This, he says, is "unequal, consequently unjust and oppressive," and he cites the married man " with six, eight, or ten Children." When he gets to his own proposals he puts as a footnote to his scheme of taxes "Bachelors to be double-taxed, if of 2 I years of Age." His scheme of taxes is "A Proposal for raising one only Tax on the Consumers of Luxuries." He would concurrently " take off our unequal Taxes and oppressive Excises," " take off our Customs, and make all our Ports free," "abolish our Monopolies," 
"withdraw the Bounties on exported Corn," and make other changes that need not be cited.

The scale of Decker's suggested tax is worked out at threehalfpence in the pound. There are eighteen steps of which a few will suffice as examples-

All Persons-

I. Keeping two Coaches and Six for their Use

6. Wearing Jewels for their Dress, besides Necklaces, Solitaires, Rings or Ear-Rings

7. Keeping a Sedan Chair for their Use

13. Drinking Wine in their Houses, Lodging or Service.

18. Drinking Tea, Coffee, or Chocolate, in House, Lodging or Service.

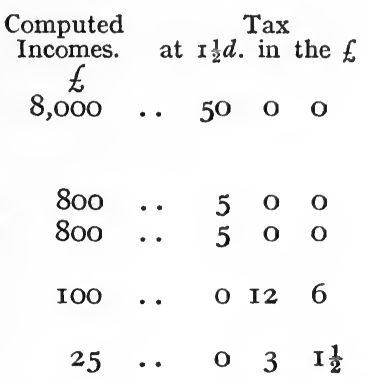

Of this scheme he says, in the discussion that follows:-

"Secondly, all Persons tax themselves voluntarily, than which nothing can be easier or more equal, and an easy Way of raising Taxes will always produce the most Money and the fewest Murmurs" (I749).

\section{Hume (I7II-I776).}

"The best taxes are such as are levied upon consumptions, especially those of luxury; because such taxes are least felt by the people. They seem, in some measure, voluntary ; since a man may chuse how far he will use the commodity which is taxed: They are paid gradually and insensibly: They naturally produce sobriety and frugality, if judiciously imposed: And being confounded with the natural price of the commodity, they are scarcely perceived by the consumers. Their only disadvantage is, that they are expensive in the levying.

"Taxes upon possessions are levied without expence; but have every other disadvantage. Most states, however, are obliged to have recourse to them, in order to supply the deficiencies of the other.

"But the most pernicious of all taxes are the arbitrary. They are commonly converted, by their management, into punishments on industry ; and also, by their unavoidable inequality, are more grievous than by the real burden which they impose." -Essays," II. vii. "Of Taxes" (I74I).

"It is an opinion, zealously promoted by some political writers, that, since all taxes, as they pretend, fall ultimately upon land, it were better to lay them originally there, and abolish every duty upon consumptions. But it is denied, that all taxes 
fall ultimately upon land."- "Essays," II. viii. "Of Taxes" (I74I).

In the earlier editions, the following sentence occurs near the end of the Essay:-

"They must be very heavy taxes, indeed, and very injudiciously levied, which the artizan will not, of himself, be enabled to pay, by superior industry and frugality, without raising the price of his labour."

In the quarto edition of I768 (London, 2 vols.) this passage takes its place :-

"No labour in any commodities, that are exported, can be very considerably raised in the price, without losing the foreign market: and as some part of almost every manufactory is exported, this circumstance keeps the price of most species of labour nearly the same after the imposition of taxes. I may add, that it has this effect upon the whole: For were any kind of labour paid beyond its proportion, all hands would flock to it, and would soon sink it to a level with the rest" (I768).

\section{Montesquieu (I689-I755).}

“ - taxes (impôts) can be levied upon persons, land, or goods; upon two of these things, or upon all three.

" In taxes (impôts) upon persons, the unjust proportion would be that which exactly followed the proportion of property (biens). The citizens of Athens were divided into four classes. Those who drew from their property 500 measures of fruit (dry or liquid), paid one talent; those who obtained 300 measures paid half a talent; those who had 200 measures paid ten mines, or one-sixth of a talent; those of the fourth class (these were mercenaries without property: footnote) paid nothing. The rate (taxe) was just, although it was not at all proportional : if it did not follow the proportion of goods, it followed the proportion of needs (besoins). It was considered that all had equal physical needs; that physical necessities should not be taxed; that useful things came next, and should be taxed, but less than superfluities; and that the magnitude of the tax (taxe) upon superfluities should prevent superfluities.

"In taxes on land, different kinds of property have been put into classes. But it is very difficult to recognise these differences, and still more difficult to find people who are not interested in disregarding them. There are here two kinds of injustice: injustice concerning the man, and injustice concerning the thing. But if in general the tax is not excessive, if abundant necessaries 
are left to the people, these special injustices are of little account. But if, on the contrary, enough is not left to the people for bare livelihood, the least disproportion will be of the greatest consequence.

Taxes (droits) upon goods are those which people feel least, because a formal demand is not made for them. They can be so wisely managed that the people will hardly know that they are paying. For this, it is of great consequence that the seller should pay the tax (droit). He knows that he does not pay for himself ; and the buyer, who pays in the end, confounds it (i.e. the tax) with the price. Some writers [Tacitus, "Annals," XIII.] have said that Nero took off the tax (droit) of the twenty-fifth part of slaves sold; but he only made the seller pay it instead of the buyer ; the order, which left the tax entire, appeared to remove it. .

". . . Besides, if the citizen pays, perpetual searches in his house are necessary. Nothing is more contrary to liberty" (III. vii.).

" . . We shall repeat, in passing, of a tax (impôt) established in some states upon different kinds of civil contracts. Considerable knowledge is necessary to defend one's self against the tax-farmer (traitant), these things being subjects of subtle discussions. Besides, the tax-farmer, an interpreter of the rules of the prince, exercises an arbitrary power over fortunes. Experience has shown that a tax (impôt) upon the paper on which the contract is to be written is much better" (III. ix.).

"Tributes (tributs) ought to be very light in despotic governments. Otherwise, who would like the trouble to cultivate the earth ? . . . Tributes ought to be so easy to discern and so clearly established that they can neither be increased nor diminished by those who levy them. A portion of the fruits of the earth, a rate (taxe) per head, a tribute of so much per cent. upon goods, are the only suitable ones" (III. x.).

". . General rule: tributes can be made heavier in proportion to the liberty of the subjects ; they must be moderated as servitude increases" (III. xii.).

" A tax (impôt) per head is the most natural to slavery ; a tax on goods the most natural to liberty, because it comes home less directly to the person.

“... The natural tribute (tribut) of the moderate government is the tax (impôt) on goods. This tax, being really paid by the buyer, although the merchant (marchand) advances it, is a loan which the merchant has already made to the buyer: thus we must regard the merchant (négociant), both as the general debtor of the State, and as the creditor of all the individual members. He advances to the State the tax (droit) which the buyer will pay him some day; and he has paid, for the buyer, 
the tax (droit) that he has paid for the goods " (III. xiv.).-Montesquieu, "L'Esprit des Lois" (I748).

\section{Justi (I720-I77I).}

"It is equally a fundamental principle that taxes and imposts (Stewern und Abgaben) should be levied on all subjects in just (gerechter) equality, for here the obligations of all the subjects are proportionate, and all have an equal share in the protection of the State and other benefits arising from the unity of a common body. If, however, this just equality is to be observed, then the proportionate amount of property must chiefly be taken as a basis, because the protection of the state expresses itself chiefly in respect of property, and because those who possess much property undoubtedly enjoy more protection than those who have little or none. Thus a larger view must be taken of subjects that are poor, or that have little property, in arranging imposts (Abgaben) for generally speaking we cannot say that they gain anything. For whether indeed they earn their most pressing necessities and sustenance, yet it cannot be maintained that they gain anything if they can spare nothing. Yet we must employ this fundamental principle with such limitations that the former rules are not contradicted; for if indeed all subjects must pay their imposts (Abgaben) in just equality according to the amount of their property, yet the nature and aim of different kinds of goods do not permit that all commodities are able to bear equally heavy imposts." -J. H. G. von Justi, "Staatswirtschaft," Vol. I. § 228 (I755).

\section{§ 4. THE PHYSIOCRATIC PERIOD.}

With Quesnay we arrive at the establishment of a definite school of economists-The Economists, as they called themselves, the Physiocrats, as they have come to be called. They developed a distinctive theory, whose chief significance was in its bearing on taxation. Trade, manufactures, capital applied in any use except in agriculture, paid for the support of those engaged, and no more. But land yielded a surplus, land alone gave a "produit net." However you taxed, land would finally pay the tax-it must, by the nature of the case. Obviously then, the sensible thing was to tax land, and to tax nothing else. Landowners would not be hurt-they were already paying all taxes unconsciously. The change would only mean the avoidance of needless circuitousness. Locke had said nearly as much sixty 
years earlier, but whereas he was content to say that " taxes, however contrived, . . . in a country where their great fund is in land, for the most part terminate upon land," the Physiocrats declared that by natural laws all taxes must come from land.

As Adam Smith was the disciple and to some extent the product of this school, the publication of "The Wealth of Nations" marks conveniently the end of the Physiocratic period (I756-I776) and the beginning of the next. Within it occur the "Lectures of Adam Smith," accessible in a work under that title, edited by Professor Cannan from the manuscript notes of a student at Adam Smith's classes. The interesting question of the source of the famous four maxims suggests a comparison between the Adam Smith of the "Lectures" and the Adam Smith of "The Wealth of Nations," with references to the works issued in the interval. Of these works the "Mémoires " of Moreau de Beaumont is the most significant, since Smith is known to have used it. Baron Bielfeld's "Institutiones Politiques," which gives three maxims-proportional equality, least disturbance and vexation, convenience in time and manner of payment -was issued before Beaumont's work, for the first edition was issued in 1760 , and a corrected edition appeared in 1767 , a year before the publication of the " Mémoires."

Such as cling to the "great man," conception of history would probably have less interest in this period than in the next, but those who are as curious about the forces that produce the man as about the forces he sets in action will find in the quotations from Beaumont, Bielfeld, Turgot, Kames, Verri, Steuart, far more than a pre-shadowing of the maxims in "The Wealth of Nations." Thus Turgot gives Equality through Proportional payments ; and Certainty. So also do Bielfeld, Steuart and Beaumont, and the two former add Convenience. Economy is touched upon by Bielfeld and Steuart, and is dealt with by Verri with striking emphasis.

Verri's rendering of Economy has reference chiefly to the welfare of the community : he is thinking rather of economical systems of taxation than of economical ways of collecting 
taxes. His canons have a particular interest from the point of view taken up in this book.

Arthur Young and Isaac Pinto represent the school that viewed taxes on commodities as the best of taxes. Arthur Young represents the extremest reaction from the SingleTax dogma of the Physiocrats. The ideal of taxation, he says, is not to fix all taxes upon one thing, but to levy them upon as many things as possible.

Sir James Steuart's work was issued before Adam Smith's, but it established nothing new that was important, nothing important that was new, in the matter of taxation or of economics generally. Henry Howe, Lord Kames, or Lord Kaims, was a discursive and voluminous writer who devoted a considerable section of his "Sketches of the History of Man" to Finance. He lays down the sound economic doctrine that "All taxes are laid upon persons" (II. VIII. iii.) and gives six " Rules to be observed in taxing."

Isaac Pinto was a writer held in very high esteem by Dugald Stewart, but it is not easy to see what aroused Stewart's admiration.

In this period, the idea of payment in proportion to income is often put as a reform; to-day many economists would consider it reactionary. But many of the writers of this time lived under conditions where there were exemptions, as of nobles and clergy, and where the mass of the people were burdened with taxes, direct and indirect: to them taxation in proportion to income was a vindication of equality. It is not till later, however, that the idea of proportionate payments comes forth as a doctrine-not until it is evoked to meet the suggestion of progressive taxation.

Quesnay (I694-I774).

Quesnay writes in the article "Fermiers" ("L'Encyclopédie," I756-7) :-

"Arbitrary taxes (taxes) are too terrifying and too unjust not to be always powerfully opposed to the re-establishment of agriculture. Proportional distribution is hardly possible; it does not appear possible to regulate it by a valuation and a tax (taxe) on land, for the two kinds of agriculture of which we have spoken [i.e. large and small farming] show great differences 
in the produce of lands of the same value; so, while the two kinds of culture remain and differ, the land cannot serve as a proportional measure for the imposition of a tax (taille). If lands are taxed according to their actual state, the table becomes defective according as large farming increases; besides, there are provinces where the profit upon cattle is much more considerable than the produce of the harvest and others where the produce of the harvest is more than the profit drawn from cattle ; more, this diversity of circumstances is very susceptible of change. It is then hardly possible to imagine any general plan of establishing a proportional distribution of taxes (impositions)."

Yet he suggests that an attempt could be made to form an assessment based on declarations.

"It will be sufficient then to compel the husbandman ( $l a$ boureur) to give every year to the collectors a faithful declaration of the quantity and the nature of the property (biens) of which he is the owner or the tenant (fermier), and an laccount of his harvests, cattle, etc., under penalty of being arbitrarily assessed if convicted of fraud."

From traders in towns he would have declarations "of the extent and objects of their trade," which would be " accepted or contested by the collectors; and in the latter case it would be approved or adjusted in an assembly of the inhabitants of the parish."

In the article "Grains" in "L'Encyclopédie," I757, he gives fourteen Maximes, afterwards developed into the thirty "Maximes Générales." Of these there are three that touch upon taxation :-

“V. Impôt Non Destructeur. That taxes (impôt) should not be destructive, or disproportionate to the mass of the income (revenu) of the nation; that their increase should follow the increase of income, and that they should be directly based on the net return (produit net) of land, and not on the wages of men, nor upon commodities, where they would increase the expenses of collection, be prejudicial to commerce, or destroy annually a part of the wealth of the nation. Neither should they take the wealth of farmers of land: for the advances of agriculture of a kingdom ought always to be viewed as an immovable that should be carefully preserved for the production of taxes (impôt), of income (revenu), and of subsistence of all classes of citizens : otherwise taxation (impôt) degenerates into a spoliation and causes a decay which quickly ruins a State." 
From this maxim, the editor of "Collection des Economistes," M. Eugène Daire, traces the aphorism of the Physiocrats, "Indirect taxes (impositions), poor peasants; poor peasants, poor kingdom ; poor kingdom, poor sovereign." 1 But it is doubtful whether the Physiocrats did more than quote a saying already old in their time.

The Twenty-Eighth Maxim runs:-

"The administration of finance, whether in the collection of taxes (impôts) or in the expenses of government, should not give rise to fortunes in money which steal a part of revenues (revenu) from circulation, from distribution, and from reproduction."

The other maxim (No. 26) is of no importance in the present inquiry. (I $75^{6-\mathrm{I} 757 .)}$

\section{Rousseau (I7I2-I778).}

"The contributions which are levied on the people are of two kinds ; real, levied on things, and personal, paid by the head. They are both called impôts and subsides. When the fixed sum is granted the word subside is used; when there is granted the total produce of a rate (taxe) then it is an impott. We find in 'L'Esprit des Loix' that an impost per head is most proper to servitude, and real taxation more conformable to liberty. That would be incontestable, if 'circumstances per head' were equal ; for nothing is more disproportionate than such a rate (taxe), and it is above all in proportions exactly observed that the spirit of liberty consists.

"But if the rate (la taxe) per head is exactly proportioned to the means of individuals, as that called in France the 'capitation' might be, and which in this manner is both real and personal, it will be the most equitable, and consequently the most agreeable to free men. These proportions appear at first easy to observe, because as they relate to the stake that each one has in the world the indications are always public; but besides the fact that avarice, credit and fraud know how to escape, it is rare that all the elements which ought to be considered are reckoned in the calculations. First of all, we should reckon the relation of quantities, according to which, all things equal, whoever has ten times more goods than another should pay ten times more. Secondly, the relation of custom, that is to say, the distinction between necessities and superfluities. Whoever has only simple necessities ought to pay nothing at all; the taxe (taxe) on whoever has superfluities may extend at need to 
everything beyond his necessities. . . . A third relation, which is never reckoned but which ought to stand first, is that of the utilities which each one draws from the social confederacy, which powerfully protects the immense possessions of the rich, and scarcely leaves a poor wretch in the enjoyment of the hut he has built with his hands. ${ }^{1}$. .

"If we put all these things carefully together, we find that to levy taxes (les taxes) in a manner that is equitable and truly proportional, the imposition ought not to be made only in proportion to (en raison des) the possessions of the contributors, but in a ratio compounded of the difference of their conditions, and the superfluity of their possessions." -J. J. Rousseau, " Discours sur l'Economie Politique" (I758).

\section{Bielfeld (I7I7-I770).}

"The increase of the number of inhabitants, first object of finance.

"Increase of wealth, second object of finance.

"Encouragement given to the production of natural commodities, third object of finance.

"The fourth object of the Department of Finance is to find the most convenient and least onerous manner of levying taxes (les Impotts), and of collecting the public monies."

"Contributions (Les Contributions) should have three properties :-

"I. A proportional equality, that is to say, that all the citizens, and also, if possible, strangers within the state, should concur in supporting it, according to their faculties and wealth.

" 2 . That the payment should cause the least disturbance

'A view of government frequently expressed. Locke says, "Government has no other end but the preservation of property" ("Civil Government," § 94). In Adam Smith's "Lectures" this passage occurs: "Till there be property there can be no government, the very end of which is to secure wealth, and to defend the rich from the poor" (I. \& 2). This is reproduced in "The Wealth of Nations" thus: "Civil government, so far as it is instituted for the security of property, is in reality instituted for the defence of the rich against the poor" (V. I. part 2).

But such ideas have by no means been always received with approval. The curious will find like sentiments put into the mouth of an arrant rascal, and as proof of his rascality, in a sententious story published in 1828, called "The Red Barn." The work was written round a notorious murder-trial, and once had a great vogue. In chapter xiii, " Beauty Smith," a rogue by profession, says "As for laws, they were made by the rich for their own protection and the disadvantage of others."

See also p. rir. 
possible to the citizen, and that vexations connected with it should be avoided.

" 3. That each contributor should be able to pay his portion in the most convenient manner, at a time when he is best able to pay.

"All can be reduced to these three principles."-Baron Bielfeld, "Institutiones Politiques," Vol. I., Chap. xi. and xii ( $N$. Edition, revue, corrigée et augmentée) (I767). First edition, Hague, I76o.

\section{Mirabeau (I7I5-I789).}

" Economic policy consists then in this, that the people should pay as much as possible, and think they pay less " (The opening phrase is "La politique œconomique ")._" " Theorie de l'Impôt," Victor de Riquetti (Mirabeau), Résumé I. (I760).

"The more the individual pays, and the more the public spends, the happier are the people. Why is that? Because the contributions of the individual are nothing but the service which he renders to the public; and the expenditure of the public, likewise, is only the guardianship (tutelle) of individuals or the surety of the equivalent, which they should receive."Ibid.

"We have just said that there are three conditions essential and necessary to imposition (imposition).

" I. That it should be established immediately at the source of revenues.

" 2. That it should be in a known proportion, and suitable to these revenues.

"3. That it should not be overburdened with the expenses of collection."- “Théorie de l'Impôt," VII. (I760).

\section{Pesselier (I7I2-I763) or La Rivière (I720-I794).}

There is a criticism of Mirabeau's " Théorie de l'Impôt," published as a "Supplément" in I76I-the year after the publication of the "Théorie." It is called "Doutes Proposés à l'Auteur de la Théorie de l'Impôt," and it bears no name. It has been attributed to $\mathrm{La}$ Rivière-there is a note to that effect in a volume of the Goldsmith's Library, a volume where the two works are bound together. But Stammhammer in his "Bibliographie der Finanzwissenschaft" attributes the work to Ch. Etienne Pesselier.

The writer sets out six doctrines or theories laid down by Mirabeau, and subjects them to analysis and criticism. Of these only the first is to our purpose. 
" Ist. Impositions, according to you, are voluntary offerings, and not debts that are paid. . . W Will every one be free, or will personal interest be forced to yield to the common good ? In the first case, the 'offering' will be nothing. In the second, it will cease to be free."

The second deals with the proportion of net produce (produit net) that should be taken in taxes. Mirabeau had fixed this at one-third in the "Théorie de l'Impôt," quoting several sets of figures. In the "Supplément" of I776 he says one-tenth, giving explanations of the change under nine heads, amounting to this, that the conditions of France which in 1760 led him to fix the proportions at one-third no longer obtained. An explanation earlier in the book ("Supplément") is more succinct.

"We have said in effect that this portion (i.e. part of the net produce to be taken in taxes) ought to be fixed by the nation in a law for ever immutable, called the Fiscal Law ; and as it must be once decided, I do not hesitate to say that I think it reasonable and sufficient if the Fiscal Law attributes to the sovereign two sols to the livre, or "one-tenth of the net produce. There will be an outcry at these words, and I shall be confronted by my statement in the 'Théorie de l'Impôt,' where I assigned a third to the sovereign. But in this it is necessary, to speak in legal terms, to distinguish provisional from full possession." -Supplément, I. v. (I76I).

\section{Adam Smith (I775-I839). First Period. The Lectures.}

"All taxes may be considered under two divisions, to wit, taxes upon possessions and taxes upon consumptions. These are the two ways of making the subjects contribute to the support of government. The land tax is of the former kind, and all taxes upon commodities the latter. Possessions are of three kinds, to wit, land, stock and money. It is easy to levy a tax upon land. ...

" Taxes upon land possessions have this great advantage, that they are levied without any great expense.

"Another advantage of a land tax is, that it does not tend to raise the price of commodities, as it is not paid in proportion to the corn and cattle, but in proportion to the rent."-Lectures, III. § I.

"Taxes upon possessions are naturally equal, but those upon consumptions naturally unequal, as they are sometimes paid 
by the merchant, sometimes by the consumer, and sometimes by the importer, who must be repaid it by the consumer.

"Taxes upon consumptions have however some advantage over those on possessions. They are not felt, being paid imperceptibly; but a person possessed of a thousand pounds of land-rent feels very sensibly an hundred pounds going from him.

“ . . . Taxes on consumptions have still another advantage over those on possessions. If a person be possessed of a land-rent of an hundred pounds per annum, and this estate be valued at a high rate, he perhaps pays $£ 20$ to the government. The collector must be paid at a certain time of the year, and few people have so much self-command as to lay up money to be ready. He has therefore $£ 20$ to borrow to answer his present demands. When the next payment comes, he has not only the tax to pay, but also the interest of the money borrowed the former year. He begins to encumber his estate; and thus upon examination it will be found that many landholders have been ruined. The best method of preventing this is to make the tenant pay the land-tax in part payment of his rent. The taxes on consumptions are not liable to this inconvenience."-Lectures, III. § 2.

[These lectures were delivered between the years I76I and I764. They were printed in I896 (Clarendon Press) under the title " Lectures on Justice, Police, Revenue and Arms, Delivered in the University of Glasgow by Adam Smith, Reported by a student in I763, and Edited with an Introduction and Notes by Edwin Cannan.']

\section{Turgot (I727-I78I).}

Turgot (Anne Robert Jacques Turgot, Baron de l'Aubre) examines "Impositions directes" and "Impositions indirectes." The former he divides again :-

" On persons or on lands (terres).

"That upon persons, in itself offends our reason; it could never have been imagined but through idleness and a desire for haste.

"It is impossible that it should be uniform.

" I. Because there are people who have nothing ;

" 2. Because, if one only wished to tax persons who are nothing but a mass of needs, it would at least be necessary to tax (taxer) on the basis of the lowest class of society; and, at so low a rate, the tax (imposition) would not bring in much.

"It is necessary then to revert to a classification of persons 
approximately according to their powers (facultés). Then this is no more than a tax (imposition) upon goods, made arbitrarily and without rule."-Impôt, I.

An analysis of Impositions indirectes follows, ending thus :-

"After having concluded that direct taxes (imposition) on landed property (fonds) is the only tax (imposition) conformable with principles, we must establish first of all upon what part of the produce of landed property it should be put; afterwards, how it ought to be distributed and collected.

"I have already said that it is only the landed proprietor who should contribute to taxes (imposition) ; the first reason is that he alone has an interest in preserving the permanent order of society. What does it matter to an industrious man what becomes of the government? With his arms he has always the same resources: it is perfectly indifferent to him whether it is Peter or James who makes him work. The second reason, and the most peremptory, is that the owner of land (fonds) alone has a true revenue." - Ibid.

In the "Discussion sur le revenu," which follows immediately, he says :-

"Let us return then to ask from the landowner (propriétaire), and in money, the part of his revenue of which the State has need.

"What should we ask from him ? How should we ask it ?

"Two different systems.

"To ask from each a part of his revenue, a fixed portion, is the system of the tenth, or the twentieth; it is that which is proposed in the 'Théorie de l'Impôt,' 1 in 'Philosophie rurale' 2 ; it is that of the English land-tax.

"We can ask, on the contrary, a fixed sum from the nation, from each province, from each community ; this fixed sum being divided between all proprietors in proportion to their property.

"This second system, necessarily contained in the arbitrary taille, has also been adopted in the districts of the "cadastre" (land register), or of the real taille. It is indeed to this system that the 'cadastre' properly applies. For what is the use of a fixed land-register, if a proportional part of a varying revenue is demanded? But, to make a distribution, a fixed table is necessary. There are altogether only four possible systems of territorial impositions (impositions).

1 and ${ }^{2}$ By Mirabeau, I760 and I763 respectively. 
"First. That of a proportional part of the produce (fruits) ; it is that of the dime, of which I have already spoken, and whose advantages and inconveniences I have already developed.

"Secondly. That of a proportional part of the revenue (revenu); it is that of the twentieths.

"Thirdly. That of a fixed sum divided each year among the contributors, according to what is known of their produce; that is very like a system of an arbitrary taille limited to landed property.

"Fourthly. That of a fixed sum, distributed according to a fixed valuation of inheritances; which is the system of the cadastre or the real taille.

"The system of proportional parts of income (revenu) would have great advantages.

"An immutable law would end for ever all disputes between government and people, above all by fixing a quota for war and for peace. Sales and purchases could be arranged on that footing, and the part of the net produce containing the tax would no longer be bought, just as the curé's part is not bought. After some time, it is quite true that no one would pay any tax. But the King would be the owner of a proportional part of the income of all land.

"This income would increase with the wealth of the nation, and if this increase of wealth increased needs, there would be sufficient for them. . . . If then it were possible to succeed in establishing this proportional tax on income, there could be no hesitation in preferring this way of raising public revenues to any other.

"But I confess that the thing appears to me impossible. . . . It is necessary then to keep to the distribution of a fixed sum, except that the amount of the fixed sum should be regulated in a certain proportion with the income of the nation; the possibility and the means of which I shall explain later." "Plan d'un Mémoire sur les Impositions" (I764).

\section{Mercier de la Rivière (I720-I794).}

Mercier de la Rivière defines a tax as a portion taken from the annual revenues (revenus) of a nation. Revenu, as he explains immediately afterwards in its physiocratic significance, is wealth that can be consumed "without prejudicing annual reproduction," that is, the "produit net" alone. A tax then, is a part of the "produit net" and can only be raised from it.

"Thus the essential form of a tax (impôt) consists in taking it 
directly where it is, and in not trying to take it where it is not, that is, by indirect taxes. There are two kinds of indirect taxupon persons and upon negotiable things." - "L'Ordre Naturel des Sociétés Politiques," chap. iv. (I767).

"A tax upon persons is necessarily an arbitrary tax, and consequently destructive of the rights of property; for what clear measure can we take to fix the amount of such a tax ? . . . A tax upon negotiable things has the same defect; however we may regard it, it is impossible to make an attempt to fix the proportion. . . . It is impossible that it should not be arbitrary." -Ibid., chap. v.

The fundamental rule of taxation, of course, is that it should be levied solely on the net product of the land. There are two fundamental rules of the public revenue given in an earlier chapter (chap.i.), deduced from the principle that "it is necessary to the public revenue so that it will not be prejudicial to the sacred rights of property." The two rules are-

"The first, that so as not to destroy the rights of property of subjects, it (the public revenue) ought not to be arbitrary; the second, that so that it will not be arbitrary, it should only be the product of a co-proprietorship incommutably acquired by the sovereign, and confined to the limits set both upon it and upon all individual proprietors."

"This establishment of a public revenue being made in favour of property," he says later, "cannot be destructive of property." -Chap. i. (I767).

\section{Dupont de Nemours (I739-I8I7).}

Dupont de Nemours, after giving a description ${ }^{1}$ of taxation (l'impôt), proceeds thus :-

"Taxation (l'impôt), as a preserver of property, is the great bond, the federative knot, the vinculum sacrum of society. . . . It does not rest with men to assess taxes according to their caprice : they have a basis and a form essentially established by the order of nature. ... Taxes should supply expenses perpetually renewed: they can only be taken, then, from wealth that is renewed.

"... The portion of crops called the net return (produit $n e t$ ) is then the only one to contribute to taxation, the only one that nature has made suitable for the purpose. . . . Indirect taxes (impositions); poor peasants. Poor peasants; ooor kingdom. Poor kingdom, poor sovereign. . . .

${ }^{1}$ See p. 259. 
“... We have just seen that if an indirect route is taken in raising taxes (impot), they are none the less paid, in the last analysis, by the produit net of landed property. . . . It is then evident that taxes (impôts) should be levied directly upon the produit net.

"... First of all, it is evident that the proportion of the tax (impôt), with the produit net, ought not to be arbitrary. . . .

"... It is further evident that taxes (impôt) cannot be invariably fixed at a determined sum. . . .

"... The proportion of the tax (impôt) with the produit net, which constitutes the only disposable wealth, ought to be such that the lot of landed proprietors is the best possible, and that their state should be preferable to any other in society. . . .

"... This natural and legitimate proportion of taxes (impot) with the produit net which should pay it, is established of itself in a growing society. For then there are landed proprietors who, pressed by the necessity of submitting to the tutelary authority that they raise up in their midst, for a mutual guarantee of the enjoyment of the property they possess, will voluntarily consecrate, in their own interests, a part of the produit net of their domains, to supply the expenses of the services of this protecting authority. ...

“.. Thus then the greatest possible public revenue, increasing daily, is the most profitable that can be to all members of society, is burdensome to no one, costs nothing to anybody, does not curtail the property of any one at all." - " De l'Origine et Progrès d'une Science Nouvelle," $§$ xiii., xiv., xv., xvi., xvii. (I767).

There are one or two references, in these passages, to $\S$ IV. and $\S$ III., which give a succinct description of the produit net.

\section{Sir James Steuart (I7I2-I780).}

"I divide, therefore, modern taxes into three classes.

"I. Those upon alienation, which I call proportional ;

" 2 . Those upon possessions, which I call cumulative or arbitrary; and

" 3. Those exacted in service, which I call personal."

He gives examples, thus :-

I. All excises, customs, stamp-duties, postage, coinage, and the like.

2. Land-taxes, poll-taxes, window-taxes, duties upon coaches and servants, that upon industrie, in France, and 
many others. (Later, chap. iv., he adds Taille, Fourage, Capitation, Dixième, etc.).

3. The corvée, in France; the six days' labour on the high roads, and the militia service before pay was allowed in England

“. . however different they may prove in their effects and consequences, they all agree in this, that they ought to impair the fruits and not the fund; the expenses of the person taxed, not the savings ; the services, not the persons of those who do them. ... This is a fundamental principle in taxation; and therefore public contributions, which necessarily imply a diminution of any capital, cannot properly be ranged under the head of taxes." - "An Inquiry into the Principles of Political Economy" $(1767)$

"I have followed another course. I have been for multiplying the objects of taxation as much as possible, and for making them more in proportion to expense than to property or income. But that I may conform myself in some measure to the ideas of those who have examined the same subject, I shall propose a tax, which would fill up the place of every other ; and could it be levied, would be the best perhaps ever thought of. It is a tax, at so much per cent. upon the sale of every commodity."-Ibid., V. xii. ( 1767$)$.

"The great advantages of proportional taxes over the cumulative, relatively to those who pay them, may be reduced to three.

"First. The proportion between the tax and the object taxed is determinate.

"Secondly. This proportion may be known to everybody.

" Thirdly. The time of paying the tax is regular and gradual ; because in paying for the commodity you pay for the tax, and your liberty in buying such commodities is unrestrained, and consequently, the expense is supposed to be in proportion to what your income can afford."-Ibid., V. xiv., A Recapitulation.

\section{The Editors of Voltaire ( 1767$)$.}

"Taxes upon the produce of the earth are the most useful to those levying taxes, the least onerous to the payers, the only taxes that are just because only here does each pay according to what he possesses, according to the interest he has in the maintenance of society." - "Avertissement des éditeurs de l'édition de Kehl " : "L'Homme aux Quarante Ecus," par Voltaire, I 767 .

annual taxes, however imposed, are levied upon the produce of the earth; a territorial tax only differs from others 
in that it is raised at less cost, does not fetter commerce, brings death to no branch of industry, occasions no vexation, because it can be distributed equally between different productions, in proportion to the net produce (produit net) that each piece of land (chaque terre) brings to the proprietor."-Ibid. (I767).

\section{Moreau de Beaumont (I7I5-I785).}

Jean-Louis Moreau, Seigneur de Beaumont, was Intendant de Finances from I756 until the abolition of the office, when he became President of the committee of four Counsellors of State which absorbed the functions of the Intendant. IIis "Mémoires Concernant les Impositions et Droits en Europe" were written between I756 and I768, published in four volumes in $1768-9$, and republished in five volumes in I787. Copies of the work are scarce, but there is one of each issue in the Goldsmith's Library at the Imperial Institute (University of London), both in excellent condition.

Beaumont's work deals chiefly with administrative detail, but in his comments, remarks, and suggestions there are indications of definite theories, as well as of schemes of reform. Some of these are here quoted, but a closer search might yield other interesting points of theory.

The resemblance between Adam Smith's famous maxims of taxation, and the passages in Beaumont's Introduction (Avertissement) have given rise to a considerable amount of discussion. Beaumont mentions :-

Payment in proportion to ability;

Equal Distribution ;

Uniformity ;

Absence of arbitrariness;

Certainty.

Adam Smith gave :-

Payment in proportion to ability;

Certainty ;

Convenience ;

Economy.

There is no doubt that Adam Smith used Beaumont's book, since a copy was obtained for him through " the particular favour of M. Turgot." We are not at present 
interested at all in the question of Adam Smith's remissness in acknowledging any indebtedness to Beaumont. It is sufficient for us to trace the sequence of thought. It is very probable that Smith read and used both Beaumont and Bielfeld, and, like most writers of the time, considered formal acknowledgment to be superfluous.

" Each individual is bound to contribute to the common and national cause by his labour, by his talent and in proportion to his abilities (facultés). . . . Thus the contribution is indispensable ; but the principal object, and the most interesting, is to make its distribution as equal (égale) and hence as little onerous as possible.

"Uniformity alone could put an end to all these inconveniences. . . .

"It is much to be desired that the form of these impositions could be perfected, that arbitrariness could be entirely banished, and that the assessment should be on a fixed and certain basis." - "Mémoires": Avertissement.

"A large part of impositions is paid under the name of twentieths of property, twentieths of cultivation, and twentieths of commerce and industry, leaving a considerable quantity of impositions to be distributed. We call this ' capitation.' We do not think that in any province it can exceed a third or two-fifths of the total impositions.

" How should it be distributed? We may follow the ordinary routine, and distribute it at a shilling in the pound of the twentieths.

"The nobles, and privileged persons, would find themselves pressed (foule) by this new form of distribution? We confess it, but the poorest class would be relieved, and we think it is just it should be done for them.

"We go further, and say that the distribution at a shilling in the pound will not sufficiently re-establish justice, proportional equality. ... .

"Here is our plan. We deduce it from the ancient laws, which all say that the strong should support the weak, and that the one should pay for the other.

"A new law would authorise a scale of proportion, conformable to which those who would pay three thousand livres of twentieths and more, would pay for capitation, up to 30,40 sols, and even, if necessary, 3 livres for each livre of twentieths.

"Those who would pay I,000-3,000 livres of twentieths, would pay for capitation 20, 25 and even 30 sols to the livre of twentieths." - " Mémoire sur les Vingtièmes," III. In Vol. V. of the "Traité des Impositions." 
The scale is continued, and as it is of interest to note what kind of scale resulted from Beaumont's suggestion towards " securing justice and proportional equality," it is set down here, but reversed from Beaumont's order.

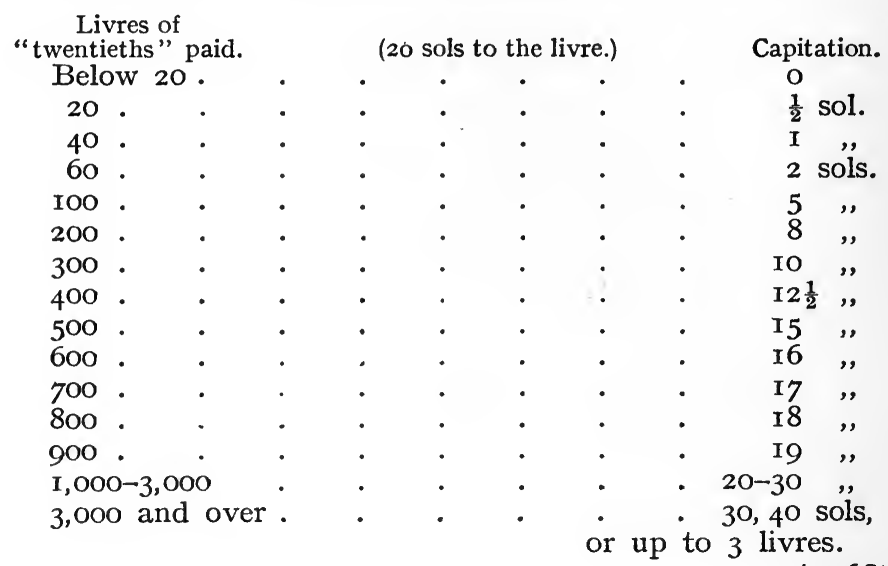

(I768).

\section{Isaac Pinto (I $7 \mathrm{I} 7-\mathrm{I} 787$ ).}

"The result of the (i.e. Mirabeau's) 'Theorie de l'Impôt' amounts to this. First, that a state like France, whose riches belong to the soil, has no real revenue but its territorial produce. Secondly, that taxes should be laid at the source of production. "Thirdly, that there should be an entire exemption in favour of labour and industry; that all the present taxes should be abolished, and the very name of finance and form be proscribed.

"Fourthly, that a general capitation tax should be established, which, by suppressing the expense of collection, may produce more, and cost less. This expense, according to him, absorbs a third of the taxes, and is a cause of general destruction.

"Fifthly, that this office should be entrusted to the municipal magistrates.

"Sixthly, the author affirms that the real revenue of France does not at present amount to anything near the taxes that are levied, and that loans are ruinous. ... .

"My own system is reducible to this conclusion.

"First, that the pretended principle of confining the whole contributive faculty of taxes entirely to the territorial produce is fallacious ; for although the landed revenue forms an important article, it is still the smallest portion of the faculties of the subject." 
(A footnote reference comes here in the English translation of I774, to the "Dialogues on the Corn Trade," from which a quotation is given, "since the great Colbert, the nature of taxation is understood. A distinction is made between duties for the purpose of revenue, and duties for the purpose of encouragement.")

"Secondly, that to lay taxes at the source of production would injure agriculture, which ought to be protected and encouraged at its source by every privilege and recompense imaginable.

" Thirdly, that nothing but articles of consumption and luxury can produce a revenue proportioned to the necessities of the state; and that it is proved by practice and experience that circulation in a great measure repairs the inconveniences that may be occasioned by taxes.

"Fourthly, that the mode of collection should be the least expensive or burdensome to the nation, taking particular care not to oppress the farmer, but this is a difficult point.

"Let me add, fifthly, that the state of exports at the custom house is the thermometer of a flourishing commerce, in a farming and manufacturing nation; that duties upon exports should be moderate; and that exportation, in some cases, should be encouraged by bounties: Importation is a different matter. It is a tribute paid to foreigners. . . . From what I have said it follows :

"Sixthly, that the treasury restores to the public the money it receives, increasing the contributive faculty by the annuities and pensions it pays. . . .

"Tenthly, that good order is not destroyed by exacting a contribution to the public stock, from all those who possess no capital, but live upon the payments yielded for their labour. They receive them from the rich, from people in easy circumstances, and even from the state. . . .

"Seventeenthly, a capitation can never be anything, in practice, but a supplementary measure.

"Eighteenthly, the specious principle of the "Theory of Taxation' "That idleness is the loss, and labour the profit of the state,' is an axiom without meaning; pompous words, that promise much, and signify nothing. An idle man, whose expense is decent, who pays taxes, who gives wages, whose money circulates, who causes a useful consumption, and supplies others with the means of doing the same, is not a burden to the state. ... We may reckon in the same class another apothegm of Mirabeau's, "That all labour is receipt, and that all idleness is expense, to the exchequer.' Fine words without reality." -De Pinto, "An Essay on Circulation and Credit," Part III. Published 
I77I, written ten years earlier. Translated into English, I774. The quotations are from the translation, corrected by comparison with the original.

Verri (I728 -I796).

"A nation may fall into decay through taxation (del tributo) in two ways. In the first case, when the amount of the taxes (tributo) exceeds the powers of the nation and is not proportioned to the general wealth. In the second case, when an amount of taxation, proportioned on the whole to the powers of the nation, is viciously (viziosamente) distributed. ...

"Taxes (il tributo) are viciously distributed when they press immediately upon the weaker classes, either where there are abuses of perception or hindrances to circulation, to export, or to the development of industry ; in a word, whenever they make difficult any action which increases the annual reproduction.

"All taxes naturally tend to be levelled uniformly upon the whole of the individuals of a state in proportion to the consumptions of each. ...

"... The first canon of taxation then should be-

"Never to press immediately upon the poorer classes. . . .

"... The second canon then should be-

"To select that form which will denote the least possible burden in its perception.

"The third canon will be-

"Clear, precise, inviolable lares should ensure impartial distribution among all the contributors. . . .

"The fourth canon then will be-

"Never to collect taxes (tributo) so as to cause an immediate increase of the expense of transport from place to place, and never to interpose between seller and buyer within the state. . . .

"And the fifth canon-

" Taxing should never be the immediate sequel to the growth of an industry."-Pietro Verri, "Meditazioni sulla Economia Politica," § XXX. (I77I).

Kames (I696-I782).

"The following proposition may be laid down as the cornerstone of taxation building, "That every man ought to contribute to the public revenue, not in proportion to his substance, but to his ability.' "- " Sketches of the History of Man," II, Sketch 8, section I, by Henry Home, Lord Kaims or Kames (I774).

"It is an article of importance in government, to have it ascertained, what proportion of the annual income of a nation may be drawn from the people by taxes, without impoverishing them. An eighth part is held to be too much ; husbandry, com- 
merce, and population would suffer. Davenant says, that the Dutch pay to the public, annually, the fourth part of the income of their country ; and he adds, that their strict economy enables them to bear that immense load, without raising the price of labour so high as to cut them out of the foreign market. It was probably so in the days of Davenant."-Ibid.

"All taxes are laid upon persons; but in different respects; a tax laid on a man personally for himself and his family, is termed a capitation tax; a tax laid on him for his property, is termed a tax on goods. The latter is the only rational tax, because it may be apportioned to the ability of the proprietor."-Sketch 8 , section 3 .

"The taxes that appear the least oppressive, because disguised, are what are laid on our manufactures. . . . To support the illusion, the duty ought to be moderate. . . . Such taxes are attended with another signal advantage : they bear a proportion to the ability of the contributors, the opulent being commonly the greatest consumers. . . A A lottery is a sort of tax different from any that have been mentioned. It is a tax, of all the most agreeable, being entirely voluntary." Sketch 8 , section 3 .

"Section V. Rules to be observed in taxing-

". . . The first rule I, shall suggest is, that, wherever there is an opportunity of smuggling, taxes ought to be moderate ; . . .

". . A second rule is, that taxes expensive in the levying ought to be avoided; being heavy on the people, without a proportional benefit to the revenue. Our land-tax is admirable : it affords a great sum, levied with very little expense. . . .

". . . A third rule is, to avoid arbitrary taxes. . . . Because many vices that poison a nation arise from inequality of fortune, I propose it, as a fourth rule, to remedy that inequality as much as possible, by relieving the poor, and burdening the rich. Heavy taxes are lightly borne by men of overgrown estates. . . .

"... A fifth rule of capital importance, as it regards the interest of the State in general, is, that every tax which tends to impoverish the nation ought to be rejected with indignation. Such taxes contradict the very nature of government, which is to protect, not to oppress. . . . I shall close with a rule of deeper concern than all that have been mentioned, which is, To avoid taxes that require the oath of party." - Sketch 8, section 5 .

"Considering taxes with regard to their effects, they may be commodiously distinguished into five kinds.

" First, taxes that increase the public revenue, without producing any other effect, good or bad.)

"Second, taxes that increase the public revenue: and are also beneficial to manufactures and commerce. 
" Third, taxes that increase the public revenue, but are hurtful to manufactures and commerce.

" Fourth, taxes that are hurtful to manufactures and commerce without increasing the public revenue.

"Taxes that are hurtful to manufactures and commerce; and also lessen the public revenue."-II. Sketch 8, section 6 .

Examples are given of each kind, thus :-

First. Land-tax, duty on coaches. The remark is added :-

" Both taxes, at the same time, are agreeable to sound principles. Men ought to contribute to the public revenue, as far as they are benefited by being protected : a rich man requires protection for his possessions, as well as for his person, and therefore ought to contribute largely ; a poor man requires protection for his person only, and therefore ought to contribute little."

Second. A tax on foreign luxuries, and a tax on horses " to prevent their increase."

"The incredible number of horses used in coaches and other wheel-carriages, has raised the price of labour, by doubling the price of oatmeal, the food of the labouring poor in many parts of Britain."

Third. Poll-tax of Ed. VI. on sheep. Marriage-tax of Will. III. Taxes " on the necessaries of life, candle, soap, leather, ale, salt, etc." They " raise the price of labour, and consequently of manufactures."

Fourth. A foreign instance is given-the prohibitive tax on the export of coal from the Austrian Netherlands.

(I774.)

\section{Arthur Young (I74I-I820).}

"The mere circumstance of taxes being very numerous, in order to raise a given sum, is a considerable step towards equality in the burden falling upon the people ; and if I was to define a good system of taxation, it should be that of bearing lightly on an infinite number of points, heavily on none. In other words, that simplicity in taxation is the greatest additional weight that can be given to taxes, and ought in every country to be most sedulously avoided."

(This is cited in the "Economic Journal," I897 (p. 2I9) as having been quoted in Parliament by Sir G. Cornewell 
Lewis in 1857, from Arthur Young. I have not been able to trace it. Lecky quotes it with approval in his " Democracy and Liberty" (I. ii. pp. I29-I30), giving a reference to Northcote's "Twenty Years of Financial Policy," pp. 309-3ro. Sir G. Cornewell Lewis said, in the speech in question: "That opinion, though contrary to much that we hear at the present day, seems to me to be full of wisdom." Lecky mentions also a speech of Thiers, January I9, I83I, in favour of " a great variety of moderate taxes.")

“. . . but in England the consumption of every commodity has increased under every burthen that has been laid on it: this has been uniformly the case with malt ; nor have we an instance of either excises or customs lessening the consumption, and consequently the price of the farmer's products. The excellence of this species of taxation has been very ably explained by several writers, who have shown that by the tax being blended with the price, the purchaser does not feel its weight, and never pays the tax but when he is best able to pay it, that is at the moment he makes the purchase. If all the taxes of England were consolidated into this general branch on consumption, our system would be still more perfect. As to their raising prices, it is as I could easily show an advantage to every class in the state."-" Political Arithmetic," I. ii. (I774).

In Chapter iii. Section i. of "Political Arithmetic," Young discusses the Physiocratic doctrine of a single tax on rent.

"Within these last twenty years," he says, " there have been an amazing number of publications in France, Holland, and Germany, on the means of promoting agriculture; and, as might well be expected, most of the writers became ideal financiers: The evils of the taille could not but strike every eye, and new modes of taxation were called for with all possible vehemence. System after system was framed, and their authors looked upon themselves as the founders of a new science; the ceconomical science, or, as they termed it, Physiocratic... their plan, which is to abolish all the long list of French taxes, and substitute a single one upon land; no idea of their own, but which is borrowed from English writers, from Locke, Decker, etc. ... .

“. . . The argument of Mr. Locke, Decker, and the French writers is, that excises and other taxes on consumption are blended by every artizan, etc., with the price of his work, which 
accumulating as they advance, render everything dearer except to people in trade who draw back the accumulation, so that the landed interest not being in trade, receives the weight at last with the progressive profits of the whole train."-I. ibid.

"Hence therefore we may venture to assert, that the encouragement of manufactures and commerce, and in general of all branches of industry, is a sure way to encourage agriculture, provided the legislature attends to a few circumstances which should not be forgotten.

"First, Not to burthen agriculture with taxes proportioned to its products, in order to lessen those on consumption.

"Secondly, Not to prohibit, or in any way restrain the export of the earth's productions, on supposition of feeding manufacturers the cheaper.

"Thirdly, To make manufacturers support their own poor.

"These conditions are so simple, and at the same time so just, that a compliance with them can never be reckoned a restraint upon any branch of national industry." - Ibid.

"That the prices of commodities rise very much in consequence of taxes, is undoubted; but that this is always an evil, there is great reason to question. I consider the fact, that cheapness of all necessaries being hurtful to national industry, as fully and completely established."-Arthur Young, " Political Arithmetic," Part II. (I779).

\section{§ 5. ADAM SMITH TO DAVID RICARDO}

The group of writers covering the period from Adam Smith to David Ricardo marks the more distinctively English period in the history of economic thought, as the Physiocratic group marks out the French period. The arrangement is, however, a rough one, more particularly in this, that the "English " period extends at least to John Stuart Mill and McCullock, and might indeed, in some respects, be continued to Stanley Jevons. However, we have already said that our grouping is chiefly for convenience of treatment; and it is doubtful if a quite satisfactory arrangement could be made on any plan.

This section gives us the famous maxims of Adam Smith; Jeremy Bentham's suggestions as to inheritance taxes; Say's argument for Progression. The doctrine that taxation should be according to ability to pay is now on the way to be a truism; but the war over its true rendering, whether into equal percentages on incomes, or on a pro- 
gressive scale, is only entering upon another campaign. That war, in fact, is not yet ended. The earlier editions of our most modern textbooks on public finance incline towards proportionalism as the orthodox and classical rendering.

\section{A. Smith (I775-I839). Second Period. "The Wealth of Nations."}

"Before I enter upon the examination of particular taxes, it is necessary to premise the four following maxims with regard to taxes in general.

"I. The subjects of every state ought to contribute towards the support of the government, as nearly as possible, in proportion to their respective abilities; that is, in proportion to the revenue which they respectively enjoy under the protection of the state.

"The expense of government to the individuals of a great nation is like the expense of management to the joint tenants of a great estate, who are all obliged to contribute in proportion to their respective interests in the estate. In the observation or neglect of this maxim consists what is called the equality or inequality of taxation. Every tax, it must be observed once for all, which falls finally upon one only of the three sorts of revenue above-mentioned ${ }^{1}$ is necessarily unequal in so far as it does not affect the other two. In the following examination of different taxes I shall seldom take much further notice of this sort of inequality, but shall, in most cases, confine my observations to that inequality which is occasioned by a particular tax falling unequally upon that particular sort of private revenue which is affected by it.

"II. The tax which each individual is bound to pay ought to be certain, and not arbitrary. The time of payment, the manner of payment, the quantity to be paid, ought all to be clear and plain to the contributor, and to every other person. Where it is otherwise, every person subject to the tax is more or less in the power of the tax-gatherer, who can either aggravate the tax upon any obnoxious contributor, or extort, by the terror of such aggravation, some present or perquisite to himself. The uncertainty of taxation encourages the insolence and favours the corruption of an order of men who are naturally unpopular, even where they are neither insolent nor corrupt. The certainty of what each individual ought to pay is, in taxation, a matter of so great importance, that a very considerable degree of in-

1 i.e. Rent, Profit, Wages. 
equality, it appears, I believe, from the experience of all nations, is not near so great an evil as a very small degree of uncertainty.

"III. Every tax ought to be levied at the time, or in the manner, in which it is most likely to be convenient for the contributor to pay it.

" A tax upon the rent of land or of houses, payable at the same term at which such rents are usually paid, is levied at the time when it is most likely to be convenient for the contributor to pay; or, when he is most likely to have wherewithal to pay. Taxes upon such consumable goods as are articles of luxury, are all finally paid by the consumer, and generally in a manner that is very convenient for him. He pays them little by little, as he has occasion to buy the goods. As he is at liberty, too, either to buy or not to buy, as he pleases, it must be his own fault if he ever suffers any considerable inconveniency from such taxes.

"IV. Every tax ought to be so contrived as both to take out and to keep out of the pockets of the people as little as possible over and above what it brings into the public treasury of the state.

"A tax may either take out or keep out of the pockets of the people a great deal more than it brings into the public treasury in the four following ways.

" First, the levying of it may require a great number of officers, whose salaries may eat up the greater part of the produce of the tax, and whose perquisites may impose another additional tax upon the people.

" Secondly, it may obstruct the industry of the people, and discourage them from applying to certain branches of business which might give maintenance and employment to great multitudes. While it obliges the people to pay, it may thus diminish or perhaps destroy some of the funds which might enable them more easily to do so.

"Thirdly, by the forfeitures and other penalties which those unfortunate individuals incur who attempt unsuccessfully to evade the tax, it may frequently ruin them, and thereby put an end to the benefit which the community might have received from the employment of their capitals. An injudicious tax offers a great temptation to smuggling. But the penalties of smuggling must rise in proportion to the temptation. The law according to all the ordinary principles of justice, first creates the temptation, and then punishes those who yield to it; and it commonly enhances the punishment, too, in proportion to the very circumstance which ought certainly to alleviate it, the temptation to commit the crime. ${ }^{1}$

1 A footnote here, "See 'Sketches of the History of Man,' page 474 , et seq." This is Lord Kames' work, quoted a few pages back. 
"Fourthly, by subjecting the people to the frequent visits and the odious examination of the tax-gatherers, it may expose them to much unnecessary trouble, vexation, and oppression; and though vexation is not, strictly speaking, expense, it is certainly equivalent to the expense at which every man would be willing to redeem himself from it.

"It is in some one or other of these four different ways that taxes are frequently so much more burdensome to the people than they are beneficial to the sovereign.

"The evident justice and utility of the foregoing maxims have recommended them more or less to the attention of all nations. All nations have endeavoured, to the best of their judgment, to render their taxes as equal as they could contrive ; as certain, as convenient to the contributor, both in the time and in the mode of payment, and in proportion to the revenue which they brought to the prince, as little burdensome to the people."-Adam Smith, "The Wealth of Nations," Book V. chap. ii. Part II. "Of Taxes" (I775-6).

"When the carriages which pass over a highway or a bridge, and the lighters which sail upon a navigable canal, pay toll in proportion to their weight or their tonnage, they pay for the maintenance of those public works exactly in proportion to the wear and tear which they occasion of them. It seems impossible to invent a more equitable way of maintaining such works. This toll or tax, too, though it is advanced by the carrier, is finally paid by the consumer, to whom it must always be charged in the price of the goods. ... When the toll upon carriages of luxury, upon coaches, post-chaises, etc., is made somewhat higher in proportion to their weight, than upon carriages of necessary use, such as carts, waggons, etc., the indolence and vanity of the rich is made to contribute in a very easy manner to the relief of the poor, by rendering cheaper the transportation of heavy goods to all the different parts of the country."-Ibid. Book V. chap. i. Part III. article I.

"The necessaries of life occasion the great expense of the poor. They find it difficult to get food, and the greater part of their little revenue is spent in getting it. The luxuries and vanities of life occasion the principal expense of the rich; and a magnificent house embellishes and sets off to the best advantage all the other luxuries and vanities which they possess. A tax upon house-rents, therefore, would in general fall heaviest upon the rich ; and in this sort of inequality there would not, perhaps, be anything very unreasonable. It is not very unreasonable that the rich should contribute to the public expense, not only in proportion to their revenue, but something more than in proportion."-Ibid. Book V. chap. ii. Part II. article I. 
This last passage is of interest as it measures the amount of deviation made by Adam Smith from the doctrine of strict proportionalism, as opposed to any form of progression. His view, as represented in these three passages taken together, seems to be that taxes should on the whole be in proportion to incomes, with some modification for putting some taxes upon the rich rather more than in proportion to their incomes.

\section{Burke (I729-I797).}

"I have always thought employments a very proper subject of regulation, but a very ill-chosen subject for a tax. An equal tax upon property is reasonable ; because the object is of the same quality throughout. The species is the same, it differs only in its quantity: but a tax upon salaries is totally of a different nature; there can be no equality, and consequently no justice, in taxing them by the hundred in the gross. . . . Suppose, for instance, that two men received a salary of $£ 800$ a year each. In the office of one there is nothing at all to be done ; in the other, the occupier is oppressed by its duties. Strike off 25 per cent. from these two offices, you take from one man $£_{200}$, which in justice he ought to have, and you give in effect to the other $£ 600$, which he ought not to receive. The public robs the former, the latter robs the public. . . . You purchase a saving of two hundred pounds by a profusion of six. . . Such has been the effect of the taxes hitherto laid on pensions and employments, and it is no encouragement to recur again to the same expedient. . . . Whenever, Sir, the encumbrance of useless office (which lies no less a dead weight upon the services of the State, than upon its revenues) shall be removed; when the remaining offices shall be classed according to the just proportion of their rewards and services, so as to admit the application of an equal rule to their taxation; when the discretionary power over the civil list cash shall be so regulated, that a minister shall no longer have the means of paying with a private, what is taken by a public hand-if after all these preliminary regulations it should be thought that a tax on places is an object worthy of the public attention, I shall be very ready to lend my hand to a reduction of their emoluments."-Edward Burke's speech of February II, I780, on the economical reformation of the Civil and other establishments. Bohn's edition, vol. II. pp. 67-8.

In the same speech, Burke put forth in detail seven principles to be applied to questions of finance. They may be 
read in full in the speech mentioned (in Bohn's edition, vol. II. pp. 69-70). We may quote here as much as is of immediate interest to us.

"Firstly, and Secondly, jurisdictions and public estates that are likelier to be used for corrupting and overawing the community than for benefiting the revenue, should be disposed of.

"Thirdly, that all offices which bring more charge than proportional advantage to the state ... ought to be taken away. ....'

"Fourthly, offices hindering the 'general superintendent of finance' ought to be abolished.

"Fifthly, That it is proper to establish an invariable order in all payments; which will prevent partiality; which will give preference to services, not according to the importunity of the demandant, but the rank and order of their utility or their justice."

Later in the speech, this point is amplified thus :-

"It is impossible, Sir, for any person to be an economist, where no order in payments is established ; . . . it is impossible for a man to be an economist, under whom various officers in their several departments may spend - even just what they please-and often with an emulation of expense ... neither the present, nor any other First Lord of the Treasury has ever been able to take a survey, or to make even a tolerable guess, of the expenses of government for any one year. . . . As things are circumstanced, the First Lord of the Treasury cannot make an estimate. .... We must class services; we must (as far as their nature admits) appropriate funds."

"Sixthly, every establishment should be reduced as far as possible to certainty.

"Seventhly, Subordinate treasuries ought to be dissolved."

(I780.)

Necker (I 734-I804).

"The choice of taxes (impotts) more proportioned to the difference of fortunes, the effort to discern those that make against the public wealth, the just distribution of each individual tax, the proscription of all arbitrary forms, the care of economy in the expenses of collection, such are approximately the different obligations that all governments should strive to fulfil."-Necker, "De l'Administration des Finances de la France," II. i. (I78r). Euvres (I785). 


\section{Gale (I783-I865).}

" It may be observed as a leading principle, that the natural use and intention of taxes is to divide the public burthens of a state among the different members who compose it, in proportion (as nearly as may be) to their respective abilities; which, in reality, is in proportion to the benefits which they respectively derive from the protection of the state. ${ }^{1}$

"Hence, then, the grand practical Principle on which the art of levying taxes must depend, in order to divide the public burthens of the state, proportionately (as nearly as may be) among the members, consists in the preservation of a par or equality (as nearly as may be) in the comparative value between money and other property, throughout the whole machine of circulation. And seeing that the comparative value between money and other property is (not as the quantity of circulating money, but) as the Product of the multiplication of the quantity by the force or velocity of the circulation;-and, seeing also, that the circulation of money and the circulation of other property is in effect one and the selfsame thing; So, consequently, in order to preserve such par or equality, the taxes ought to be levied (not in proportion to the apparent value of the property or estates of the people, but) in proportion to the Product of the multiplication of the apparent value of such property, by the force or velocity with which it shall actually circulate, or be bought and sold."-S. Gale, "An Essay on the Nature and Principles of Public Credit," South Carolina, I782 (Lond. I784).

Bentham (I648-I709).

Jeremy Bentham lays down a general principle concerning taxes in this characteristic form :-

"An important distinction is to be made between the ideal perfection of security, and that perfection which is practicable. The first requires that nothing should be taken from any one; the second is attained if no more is taken than is necessary for the preservation of the rest." - " Principles of the Civil Code," chap. xiii.

He gives a list of the taxes " which should be interdicted," in art. 33, sect. xiii, chap. xi. of Bk. II. of the "Constitutional Code." They are : Taxes on the means of political information, in particular on Newspapers; Taxes on judiciary proceedings, whether under the name of stamps or fees of

1 A paraphrase of Adam Smith's Ist Maxim, already quoted. 
court; Taxes on medicines; Taxes on insurance against calamity. With this we may read the earlier rule in the same work (Bk. I. chap. vii. sect. iv.), declaring that no tax is to be imposed for the augmentation of the "collective splendour " of the State, or of any one functionary in particular, or for the "advancement of purely agreeable or curious branches of art and science."

"Hand in hand with waste," says Bentham in "The Constitutional Code," " is to be found taxation." In the same place (chap. vi.) he says " in the case of a tax, there will always be a portion of evil, the quantity of which will be the same, be the produce ever so great or ever so small."

In " A General View of a Complete Code of Laws" he deals with administrative aims.

"A treatise upon finance ought to begin with two tables:A table of all the inconveniences which can possibly result from every kind of tax; 2. A table of all the taxes, arranged in the most convenient order for facilitating the comparison and showing the particular qualities of each one.

"First object of finance - to find the money without constraint -without making any person experience the pain of loss and of privation.

[A note is added: "This object can rarely be accomplished. The Canton of Berne levies no taxes: its government is supported by its property. It is almost a unique case, and perhaps it is not desirable that it should be general. In governments in which the people have no part, the necessity of attending to the solvability of the contributors is a species of safeguard for them."]

"Second object-to take care that this pain of constraint and privation be reduced to the lowest term.

Third object-to avoid giving rise to evils accessory to the obligation of paying the tax."-Chap. xxix.

Taxes are considered at some length in his "Manual of Political Economy."

"The practical rule which ought to be observed in judging of the expediency of any branch of expenditure is-compare the benefit of it with the burthen of a correspondent portion of the produce of the most burthensome tax. By striking off so much expenditure, you save so much tax."

Further in the same chapter (v.) is this. 
"Taxes take from present enjoyment: they diminish comfort in proportion as they are paid by each contributor out of that portion of his wealth, which, had it not been for the tax, would all of it have been spent within the year in the way of maintenance, as money is spent by a man who is said to spend his income. Taxes diminish future wealth in proportion as they take from capital. ... Taxes, therefore, take from growing wealth-I. In as far as they are levied on capital, viz., on money destined for employment in the shape of capital, or on goods or labour, of which real capital is composed; 2. In as far as they are levied on income, or expenditure in the way of income, of men who lay up money to be employed as capital, or would have laid it up, had it not been for the tax."

"Taxes are either on property, or on presumption of property. .. . The fault of direct taxes on presumption of property is inequality - that of direct taxes on property is vexation. Indirect taxes have no fault beyond the mere privation, which must be undergone at any rate."

"To an indirect tax, each man pays no more than he pleases. ... To a direct tax, each man pays what the imposer of the tax pleases. . . . Indirect taxation, as far as it will go, is therefore preferable to direct."

"Taxes ought to have no other end than the production of revenue, with as light a burthen as possible. [With a footnote : 'This principle may admit of some exceptions, but they are very rare: for example, a tax may be imposed upon intoxicating liquors, with design of diminishing their consumption by increasing the price." "]

Bentham made a strong attack upon law-taxes in his pamphlet "A Protest Against Law-Taxes." This was followed by "Supply Without Burden; or, Escheat vice Taxation."

" In a former essay," he says, referring to the "Protest," "I pointed out the species of tax which, if the reasoning there given be just, is the worst of all taxes existing or possible. The object of the present essay is, to point out that mode of supply which, for one of so great a magnitude will, I flatter myself, appear to be absolutely the best. What is that mode of supply, of which the twentieth part is a tax, and that a heavy one, while the whole would be no tax, and would not be felt by anybody?"

The answer he gives to his own riddle is " the appropriating to the use of the public all vacant successions, property of every denomination included, on the failure of 
near relations, will or no will, subject only to the power of bequest, as hereinafter limited." "Near relations" he defines as those within the degrees termed prohibited with reference to marriage. The limitation alluded to is that the new law of Escheat should apply only to half the property at present subject to the power of bequest.

\section{Rights of Man (I79I).}

The I3th article of the "Declaration of the Rights of Man " says :-

"For the support of the public power, and for the expenses of administration, a common contribution is indispensable. It should be apportioned equally among the citizens, according to their ability (facultés.) (I79I.)

A modern "Rédaction" ("La Declaration des Droits de l'Homme et du Citoyen, I er livret d'Education Civique et Sociale," par A. Belot et A. Bertrand, $5^{\mathrm{e}}$ édition), gives this-

"In the division of charges, a rigorous equality is necessary, but an equality which takes account of the power of each. The time is passed by when it could be said, 'The nobles pay by their blood (de son sang); the clergy, by their prayers; the people, by their labour.'

Adam Ferguson (I723-I8I6).

"In judging of the absolute or comparative expedience of taxes diversified in any of these ways [i.e., the ways just mentioned by the writer: " assessment on the rents of land, or other sources of private returns ... on goods as they pass in commerce ... on articles of consumption in the actual use "] the following maxims may be assumed:-

"First, that the real exigencies of the State are to be provided for at any hazard or expence to the subject. The interests of the state and of the people, when well understood, are the same. ... .

"Secondly, it may be assumed, that the private estate of the subject is in no case to be unnecessarily taxed, under pretence of a public concern. . . .

"In the third place, it may be assumed, that, as it is a principal object of government to secure the property of the subject against every invader, care should be taken, in the form of 
taxation, to fix the limits of public exaction, so as in no way to impair the security of the subject in the possession of what he has left ; that, while he is required to contribute a part of his labour to the public expence, the extent of this demand should be well ascertained, and no admission be given to arbitrary impositions, which might render the fortune of the subject in any degree precarious. It is in the confidence of a security of property that the labourer toils to obtain it, and cheerfully contributes a part of his gains to ensure the remainder.

"In the fourth place, it is evident, that no tax should be laid on in such a manner as to drain the source from which it is derived. ...

"In the fifth place, it may be assumed, that not only every real grievance, but every apparent one also, and whatever is likely to be felt as such in the imposition of taxes, is to be avoided."-Dr. Adam Ferguson, "Principles of Moral and Political Science," Part II. chap. vi. sect. v. (I792).

\section{Condorcet (I743-I794).}

"Those who have little more than necessities would then pay almost nothing, and small errors of valuation of their means (facultés) could not have any great effect.

"It would be then a useful reform in our assessed taxes (contribution mobiliaire) to exempt absolutely a certain amount of presumed income, and to tax the remainder on a proportional scale. This would become a true progressive tax. . . .

"... I do not know that the existence of large fortunes is hurtful in itself : I know that it is useful for them to be brought near an equality; I know that, otherwise, even equality of rights cannot be complete and real. I know that great fortunes are not at all necessary for that activity of industry, that happy distribution of labour, that circulation, that growth of capital, of wealth, which permits the soil to be covered with a more numerous population, and which increases, for each generation, the means of comfort and well-being. But the sudden destruction, the displacement of these fortunes, and even the instantaneous change of their use, deranging the march of industry, the actual distribution of labour, the established course of commerce, can reduce the soil of a country to nourish only a smaller population, can condemn many generations to misfortune. ...

". . It is then necessary to the common property to regulate progressive taxation so as not to make it useless for an individual to acquire a new piece of land, to invest more capital - so as not to drive him to seek investments abroad, to dabble in stocks-not to hide his fortune by false sales."-Condorcet 
[M. J. A. N. Caritat, Marquis de Condorcet], "Sur l'Impôt Progressif " (I792).

Macnab (I76I-I823).

" - two general principles which perhaps will be found to comprehend the leading doctrines of taxation. The first and grand principle of imposing taxes is, to oblige each individual to contribute to the public revenue, in proportion to his ability, without the existence of local or partial exemptions. The second is, that taxes should, if possible, be made subservient to the valuable purposes of increasing the different sources of national wealth, strength, and happiness; but even in the most desperate cases, where this is impracticable, the judicious financier ought carefully to avoid any tax which tends to check industry, distress genius, clog the operations of the farmer, the manufacturer and merchant, or oppress materially any part of the community, particularly 'the poor of the land.' Hence it is that taxes on the price of labour, on necessaries of life, and on raw materials, or capital instruments in agriculture and manufactures, carry in their bosom (as Lord Kaims expresses it) 'a slow poison.

\section{A footnote adds to these principles:-}

"The mode of imposing taxes, the expence attending gathering them, and the time fixed for payment thereof, make an important part of the system of taxation."-Dr. Macnab, "Letters Addressed to the Right Honourable William Pitt," Letter II (I793).

\section{J. B. Say $(\mathrm{I} 767-\mathrm{I} 832)$.}

"Admitting these premises, that taxation (impot $t$ ) is the taking from individuals a part of their property for public purposes; that the value levied by taxation never reverts to the members of the community, after it has once been taken from them; and that taxation is not itself a means of reproduction; it is impossible to deny the conclusion, that the best taxes, or rather, those that are least bad, are-

"I. Such as are the most moderate in their ratio.

" 2. Such as are least attended with those vexatious circumstances that harass the taxpayer without bringing anything into the public exchequer.

"3. Such as press impartially on all classes.

" 4. Such as are least injurious to reproduction.

"5. Such as are rather favourable than otherwise to the national morality; that is to say, to the prevalence of habits 
useful and beneficial to society."-J. B. Say, "A Treatise on Political Economy," III. viii. (I803).

Commenting on No. 3 of these rules, he says :-

"In fact, supposing taxation to be exactly proportionate to individual income, a tax of ten per cent. for instance, a family possessed of $300,000 \mathrm{fr}$. per annum would pay 30,000 fr. in taxes, leaving a clear residue of 270,000 fr. for the family expenditure. With such an expenditure, the family could not only live in abundance, but could still enjoy a vast number of gratifications by no means essential to happiness. Whereas another family, with an income of $300 \mathrm{fr}$., reduced by taxation to 270 fr. per annum, would, with our present habits of life, and ways of thinking, be stinted in the bare necessaries of subsistence. Thus, a tax merely proportionate to individual income would be far from equitable; and this is probably what Smith meant, by declaring it reasonable, that the rich man should contribute to the public expenses, not merely in proportion to the amount of his revenue, but even somewhat more. For my part, I have no hesitation in going further, and saying, that taxation cannot be equitable, unless its ratio is progressive."-Ibid. (I803).

\section{Dugald Stewart (I753-I828).}

"To these maxims of Mr. Smith, the following one may be added as a principle equally general in its application-

" 5. No tax should be imposed in such a manner as to drain the sources from which it is derived; (here a footnote reference to Ferguson's "Principles of Moral and Political Science," II. vi. 5) ; or, (as Sir James Steuart expresses it), "Taxes ought to affect the fruits and not the fund."-Dugald Stewart, "Lectures on Political Economy," II., IV. ii. I. Written in I800-I810, and published in 1855 .

\section{Buchanan (I779-I848).}

"To an equitable tax on income there can be no possible objection, since its object is to take from every individual a just proportion of his means for the service of the state.

"The injustice of fixing a common rate of contribution for all incomes, however various, is sufficiently obvious; since an income of $£$ Io,0oo per annum might pay, without any great hardship, a proportion which, if exacted from a smaller income, would force a retrenchment not of comforts merely, but of absolute necessaries. In matters of policy the strict rules of arithmetic do not apply; and to frame a scheme of taxation 
on any such theory, would be to sanction, under the specious appearance of equality, great practical oppression. The rate of contribution to be equitable ought therefore continually to vary, gradually ascending, until it rise to its maximum among the highest incomes." - "Observations on the Subjects treated of in Dr. Adam Smith's Inquiry into the Nature and Causes of the Wealth of Nations," David Buchanan (I8I4).

\section{$\S 6$. DAVID RICARDO TO JOHN STUART MILL.}

This is a period of settlement and consolidation rather than of development, in the field of economics. Its outstanding figure is that of David Ricardo, whose system and method reached its fullest exposition with MacCulloch.

Sismondi's contribution is interesting as an expression of the distinctively French effort towards linking the idea of taxation to what other French writers have expressed as "social solidarity." That conception runs through the whole of French political and economic thought. It helps to account for the fact that whilst English and German writers have arrived at a common conception of the essential things that make a tax (or steuer), French writers strive to express something more or less definitely relating to the idea of social consciousness, and in so striving, seem to reject the simple formula that their English and German fellow-workers have accepted. The difference is expressed, again, by the growth of what is called "Solidarisme," of which M. Charles Gide is the most distinctive economic exponent.

Sir Henry Parnell's statement of the doctrine of Minimum Sacrifice, now strongly associated under that name with Professor Edgeworth, is given together with the principle of economy ; not as suggesting two principles, but as if they were correlatives forming one principle-an interesting point in relation to the ideas expounded in the following chapter.

Generally, it seems that in this period the idea of taxes as payment for governmental protection, and the idea of proportionality as the true measure of ability to pay, are accepted as fixed; whilst the Physiocratic doctrine of taxing rent only, though still in existence, is moving into the background. 


\section{Ricardo (I772-I823).}

Ricardo's book on Political Economy is called " Principles of Political Economy and Taxation" (I8I7), and twelve of its thirty-two chapters are devoted to questions of rates and taxes. In the chapter "On Taxes" (chap. viii.) he says :-

"There are no taxes which have not a tendency to lessen the power to accumulate. All taxes must fall either on capital or revenue. If they encroach on capital, they must proportionably diminish that fund by whose extent the extent of the productive industry of the country must always be regulated ; and if they fall on revenue, they must either lessen accumulation, or force the contributors to save the amount of the tax, by making a corresponding diminution of their former unproductive consumption of the necessaries and luxuries of life. Some taxes will produce these effects in a much greater degree than others; but the great evil of taxation is to be found, not so much in any selection of its objects, as in the general amount of its effects taken collectively."

Later, in discussing the land-tax, he says-

"Everything which raises the exchangeable value of commodities of any kind, which are in very general demand, tends to discourage both cultivation and production; but this is an evil inseparable from all taxation, and not confined to the particular taxes of which we are now speaking" (chap. xii.).

He adopts, and without any criticism or discussion, the maxims of Adam Smith (chap. xii.), and the doctrine of proportions laid down in the second part of the first maxim he expresses in another form earlier in the book.

"Taxation under every form presents but a choice of evils; if it do not act on profit, or other sources of income, it must act on expenditure ; and provided the burthen be equally borne, and do not repress reproduction, it is indifferent on which it is laid. Taxes on production, or on the profits of stock, whether applied immediately to profits, or indirectly, by taxing the land or its produce, have this advantage over other taxes; that, provided all other income be taxed, no class of the community can escape them, and each contributes according to his means" (chap. ix.).

He quotes the maxims against Adam Smith himself. 
" Adam Smith considers ground-rents as peculiarly fit subjects for taxation. "Both ground rents and the ordinary rent of land,' he [A.S.] says, ' are a species of revenue, which the owner in many cases enjoys, without any care or attention of his own. Though a part of this revenue should be taken from him, in order to defray the expenses of the State, no discouragement will thereby be given to any sort of industry. The annual produce of the land and labour of the society, the real wealth and revenue of the great body of the people, might be the same after such a tax as before. Ground rents, and the ordinary rent of land are, therefore, perhaps, the species of revenue which can best bear to have a peculiar tax imposed upon them.' It must be admitted that the effects of these taxes would be such as Adam Smith has described ; but it would surely be very unjust to tax exclusively the revenue of any particular class of the community. The burdens of the State should be borne by all in proportion to their means : this is one of the four maxims mentioned by Adam Smith, which should govern all taxation" (chap. xiv.).

"Tithes are a tax on the gross produce of the land, and, like taxes on raw produce, fall wholly on the consumer. They differ from a tax on rent, inasmuch as they affect land which such a tax would not reach; and raise the price of raw produce, which that tax would not alter. ' Lands of the worst quality, as well as of the best, pay tithes, and exactly in proportion to the quantity of produce obtained from them; tithes are therefore an equal tax" (chap. xi.).

In the passage given above, Ricardo seems to apply the doctrine of proportions to persons and to things indefinitely. This is what he seems to mean when he says "tithes are therefore an equal tax." He seems, as Professor Cannan says in a comment on this passage, to overlook the fact that net produce does not vary with gross. If that is not held in mind it seems "equal " to tax persons in the proportions of the amounts of gross produce. Yet in another place, to which Professor Plehn calls attention ("Public Finance," p. II2) there is a passage in Ricardo's book where the distinction between net and gross revenue in relation to taxes is cleary considered-

"It must however be obvious that the power of paying taxes is in proportion to the net, and not in proportion to the gross revenue."-D. Ricardo, "Principles of Political Economy," xxvi. (I8I7). 


\section{Sismondi (I773-I842).}

"Taxes (l'impôts) should be considered by citizens as a compensation for the protection which government gives to their persons and properties. It is just that all should give support in proportion to the advantages which society guarantees to them, and to the outlay which society undertakes for them.

" The greater part of the expense of the social establishment is intended to defend the rich against the poor ${ }^{1}$; because, if they were left to their respective powers, the former would soon be despoiled. It is then just that the rich man should contribute, not only in proportion to his fortune, but even beyond that proportion, to sustain an order which is so advantageous to him; just as it is equitable to take from his superfluity rather than from the necessities of the other. . . .

"With these slight modifications, we may admit the general rule that every one should contribute to the maintenance of society in proportion to his income (revenu). Of the different parts of wealth, income alone should be taxed.

"Taxation is then an evil only in so far as it is an evil to buy at a sacrifice something we neither need nor desire; but also it is a good, if the thing is worth more to us and procures us more enjoyments than the sacrifice by which we obtained it takes away. If society is well organised, that should always be the case, for it always ought to be more economical to join the efforts of many for a common object, rather than to seek to attain it by a number of individual efforts. . . .

"The measure of every one's enjoyment ought always to be his income ; in the same way the share of the common enjoyments that taxation should procure for all, should always be proportioned to the income of all."- "Nouveaux Principes d'Economie Politique, ou de la Richesse dans ses rapports avec la Population," VI. i. J. C. L. Simonde de Sismondi (I8I9).

"Ist. Every tax (impôt) should be laid on income (revenu) and not on capital. In the first case, the State only spends what individuals ought to spend; in the second, it destroys what ought to support both individuals and the State.

" 2 nd. In the assessment of taxes, the net annual produce must not be confounded with income (revenu) ; for the former includes, beyond the latter, all circulating capital ; and a part of this produce should remain for the maintenance or renewal of all fixed capital, all accumulated works, and the lives of all productive workers.

" 3 rd. Taxes being the price that the citizen pays for what. 
he enjoys, they cannot be asked of him who enjoys nothing; they ought therefore never to touch the part of income (revenu) which is necessary to the life of the contributor.

" 4 th. Taxes should never drive away the wealth (richesse) which they strike: they ought then to be the more moderated as this wealth is of a more fugitive nature. They should never reach the part of income (revenu) which is necessary, so that this income may preserve itself." - (op. cit. VI. ii.).

J. Mill (I773-I836).

"A tax, to operate fairly, ought to leave the relative condition of the different classes of contributors the same, after the tax, as before it. In regard to the sums required for the service of the state, this is the true principle of distribution."-James Mill, "Elements of Political Economy," IV. viii. 3rd edition (I826) (Ist edition, I82I).

\section{Dr. W. Channing (I780-I842).}

"We will add, that we attach no importance to what is deemed the chief benefit of tariffs, that they save the necessity of direct taxation, and draw from a people a large revenue without their knowledge. In the first place, we say, that a free people ought to know what they pay for freedom, and to pay it joyfully, and that they should as truly scorn to be cheated into the support of their government, as into the support of their children. In the next place, a large revenue is no blessing. An overflowing treasury will always be corrupting to the governors and the governed. A revenue, rigorously proportioned to the wants of a people, is as much as can be trusted safely to men in power. The only valid argument against substituting direct for indirect taxation, is the difficulty of ascertaining with precision the property of the citizen."-Wm. E. Channing, D.D., "The Union" (1829).

\section{Parnell (I776-I842).}

"The principle that will be held in view in suggesting each alteration, will be that of levying the revenue which is wanted for the public service in such a manner as to occasion the smallest loss of money and enjoyment to the contributors, and the least possible impediment to the progress of national industry and national wealth; at the same time, full consideration will be given to the great importance of making every change in so gradual a manner, that nothing may happen which might give a shock to trade, or reduce the revenue below what is requisite for all the public services."- -Sir Henry Parnell, "On Financial Reform," 2nd edition (I830), chap. i. 
"If right principles were referred to, they would suggest that taxation is the price we pay for government; and that every particle of expense that is incurred beyond what necessity absolutely requires for the preservation of social order, and for protection against foreign attack, is waste, and an unjust and oppressive imposition upon the public.-Ibid. chap. viii. (I830).

\section{Chalmers (I780-I847).}

"Yet, though the first effect of these taxes [i.e., upon profits and wages] is to depress both profit and wages, the ultimate effect in which it settles down, is to depress the revenue of the landlords. The capital will gradually recover its rate of profit, in the process of its own declension; and the population will gradually recover their rate of wages, in the process (we admit a melancholy one) of their own decay. After these processes are consummated, we see the whole of the taxes virtually transferred to the proprietors of the soil. They have, in the first instance, to pay a higher price for the commodities which they use, and the labour which they employ. They, in the second instance, pay, by its being withheld from their rents, the whole addition which taxation lays on the expenses of husbandry. These two together, if there be truth in our argument, should make up the whole revenue which accrues to government. . . . And it were no small advantage, if landlords were made to bear the whole burdens of the state ostensibly, as they do really; that the importance, the paramount importance, of landed wealth and of the landed interest, would stand forth, nakedly and without disguise, to the recognition of all men." -Thomas Chalmers, D.D., "On Political Economy, etc." (2nd edition, I832).

\section{Anonymous (I833).}

"Evils of Taxation or of the Plans of raising it.

" On a review of the evils of Taxation, or of the plans of raising it, it may appear that they proceed

" Ist. From Inequality.

" 2 nd. From Procedure.

" 3rd. From Excess.

"viz., Excess :

"Ist. In as far as Taxation may deprive the Payers of the Taxes... of more than is received by the Receivers of the Taxes. ....

" 2 nd. In as far as Taxation may exact more than the Property, Capital and Industry of the Payers of the Taxes can replace.

" 3 rd. In as far as Taxation may transfer from the Payers to the Receivers of the Taxes a share of the general Income of the Country greater than is just or necessary. 
" 4 th. In as far as a levy of a Sinking Fund or Surplus Revenue may be unnecessary or of inadequate utility.

"Considering Equality of Taxation to signify taxation in due proportion to every one's means and ability to pay, that most just principle of taxation, it follows that Income, which constitutes and evidences the means to pay, is the surest basis for equal taxation. ... . As the relative expenditure of individuals is not in proportion to their relative means Taxation or Expenditure cannot fall on every one in proportion to his ability to pay." - "An Attempt to show the Justice and Expediency of Substituting an Income or Property Tax for the Present Taxes, or a Part of Them, etc." (I833).

\section{Senior (I790-I864).}

"Those writers who have maintained that whatever is raised by taxation is deducted from the revenue of the country, seem to have been led to this conclusion, by observing that the object of government is to occasion not positive but negative effects, not to produce good, but to prevent evil. . . . But it must be recollected that the mere prevention of evil is one of the principal objects even of individual expenditure. . . But both misgovernment, and that interference of the ruling power between the different classes of its subjects which we have already described as affecting the proportions of rent, profit, and wages to one another, are rather disturbing causes than necessary elements in the calculations of political economy." Nascau W. Senior, " Political Economy " (Encycl. Metropolitana, I836; reprinted I850).

\section{Rau (I792-I870).}

" I. All citizens are in duty bound to bear charges (Generality of Taxation). It may be-

"(a) that individuals by particular services of another kind, render an equivalent service, freely or by constraint, or,

“ (b) that their circumstances make them incapable of paying anything to the state, without a diminution of the necessary means of subsistence.

"2. All citizens should be included under uniform rules and a uniform standard. [In the 3rd edition, I859, this is " a standard proportioned to their relation to the state "] (Uniformity of Taxation.)

"However difficult it may be to satisfy fully this demand of justice, it should yet be a goal, to be approached by constant effort.

". . there may be, then, an impost laid on each citizen 
"(I) according to his grade as a co-partner in the advantages of the state community,

" (2) according to his ability to contribute, as established by the circumstances of his possessions."

[The 3rd edition gives taxes (Steuern) as " more closely related to these requirements than are dues (Gebïhren)].

Dr. Karl H. Rau, "Grundsätze der Finanzwissenschaft," being vol. iii. of " Lehrbuch der politischen Ekonomie," \$ 250 , $\S 25 \mathrm{I}$; and in the 3 rd edition, p. 376, Ist edition I826-I837, 3rd edition I859. (I837.)

\section{Scialoja (I8I7-I887).}

"Taxes (imposta) should always be a part of the possible (possibile) wealth, which can be taken from the income of each individual without touching his productive funds.

"They should be distributed according to the portions of utility that are drawn by the different social classes, and according to the power (faculty: facolta) of the contributors. . . .

"They should always be as small as possible-the necessary demands for social needs. ...

"They should not need heavy costs of collection.

"No tax (imposizione) should allow arbitrary powers to the collectors, to hurt liberty or private property ; nor should itself be a violation of private property, nor contrary to the public morals. . . .

"They should be paid when the contributor is best able to pay, so as to relieve their pressure. . "-Antonio Scialoja, “I Principii della Economia Sociale," VI. i. §§ II.-VIr. (I840).

\section{Torrens (I8I4-I884).}

"It is an important principle, and one admitting of the strictest demonstration, that taxes on vested property, on the rent of land, houses, and on money on mortgage, and in the public funds, have no injurious influence upon the production of wealth, or upon the national prosperity; and it is those taxes only which fall upon the actively productive class, which reduce the rate of profit, and bring a country prematurely, first to the stationary and then to the declining state.

"It may be objected that it would be unjust to tax incomes derived from vested property, without taxing in an equal degree incomes derived from capital actively employed. This objection, which is deserving of great consideration, will be admitted to be inapplicable, if it can be satisfactorily shown that exempting directly productive industry from taxation, so far from being injurious, would be beneficial to those dormant proprietors who live upon the rent of land and the interest of vested capital. . . . 
"From the principles above unfolded, a most important corollary results. A national debt, whatever may be its amount, has no injurious influence, either on the prosperity or the financial resources of a country, provided the interest upon it be paid out of taxes imposed, not upon the productive classes, but upon dormant capital." -R. R. Torrens, "The Budget," Letter VI. (I844).

\section{McCulloch (I789-I864).}

"Though taxation be necessary, it should always be kept within the narrowest limits. The best taxes, provided they produce the necessary supplies, may, speaking generally, be said to be the lightest, or those of which the pressure is least felt. But however light soever, all taxes at first necessarily encroach somewhat on the means of enjoyment or of accumulation possessed by the parties by whom they are paid ; and whatever may be their amount, and however imposed, they must necessarily fall either on the revenue of the contributors or on their capital or stock. Perhaps, indeed, there is no tax the produce of which is not partly derived from both these sources. It is, however, abundantly certain that all taxes, when judiciously imposed, and not carried to an oppressive height, occasion an increase of industry and economy, and but rarely encroach on capital. Under these conditions they operate as motives to restrain expense, and as incentives to labour and ingenuity, frequently occasioning the production of more wealth than they abstract. . . . To render an increase of taxation productive of greater exertion, economy, and invention, it should be slow and gradual."-J. R. McCulloch, "Treatise on Taxation and the Funding System," Introduction (I845).

"A diminution of expenditure, and consequently of taxation, confers an advantage on the public, similar to that which a diminution of the cost of any indispensable or highly desirable article confers on individuals . . . and M. Say, notwithstanding his wish to be epigrammatic, is justified in saying that the best system of finance is to spend little; and the best of all taxes, the least. Le meilleur de tous les plans de finance est de déspenser peu, et le meilleur de tous les impôts est le plus petit."-Ibid.

"It is easy, however, to see, notwithstanding their apparent completeness, that the characters of good and bad taxes embodied in the above maxims (A. Smith's, which McCulloch has just quoted in full) are not sufficiently comprehensive. It would, no doubt, be in various respects desirable that the inhabitants of a country should contribute to the support of its government in proportion to their means. This is obviously, however, a matter of secondary importance. It is the business of the legislator to look at the practical influence of different taxes, and to resort in preference to those by which the revenue may be raised 
with least inconvenience. Should the taxes least adverse to the public interests fall on the contributors according to their respective abilities, it will be an additional recommendation in their favour. But the salus populi is in this, as it should be in every similar matter, the prime consideration; and the tax which is best fitted to promote or least opposed to, this great end, though it may not press quite equally on the different orders of society, is to be preferred to a more equal but otherwise less advantageous tax. Had Smith restricted his maxim to taxes laid directly on property or income, he would have been quite right in saying that they should be proportioned to the abilities of the contributors. Equality, indeed, is essential to such taxes; and whenever they cease to be equal, they become partial and unjust. But in laying down a principle that is to apply to all taxes, equality of contribution is an inferior consideration. The distinguishing characteristic of the best tax is, not that it is most nearly proportioned to the means of individuals, but that it is easily assessed and collected, and is, at the same time, most conducive, all things considered, to the public interests." Ibid.

"Although, however, it be no valid objection to a large class of taxes that they are not proportioned to the means of the contributors, it may be laid down in general that no tax, whether it be proportioned to their means or otherwise, can be a good tax unless it correspond pretty closely with the conditions in the last three maxims of Smith."-Ibid. Introduction.

"If the choice lay only between a tax on property and a tax on income, we incline to think that the latter should be preferred. It will be afterwards seen that it is all but impossible to ascertain incomes with anything like accuracy, or to tax them fairly after they are ascertained. But whatever errors may be made in estimating and assessing income would be at least equalled, and probably exceeded, by those that would be made if it were attempted to estimate and assess property."-Ibid. I. iv.

"A most moderate tax laid on capital may be, and generally is, defrayed out of a saving of income; whereas an oppressive tax laid on income has in most cases to be paid partly from capital."-Ibid. p. 7 (I845).

\section{§ 7. JOHN STUART MILL TO STANLEY JEVONS.}

The preceding period was the most individualistic in the history of economic thought. There were protests and attacks upon its extreme individualism, during the period itself, but they came from writers who were- 
and who largely still are-unknown. They are dealt with at some length in Professor Foxwell's "Introduction" to Menger's "The Right to the whole Produce of Labour," and in Professor Seligman's articles "On Some Neglected British Economists" in the Economic Journal of roo3.

But the first important work that came from within the circle of orthodox economists, and which moved definitely away from the individualistic position, was John Stuart Mill's " Political Economy," a book of readable and fluent English, somewhat belated economics, and intensely interesting politics. It was a book that appealed to the general reader, and it had an influence which, as an economic treatise, it did not deserve. But Mill thought of the community as much as he did of the individual, and that differentiated his work from those immediately preceding him, who treated of the individual first, and then fitted in the community-as the typical modern English economist, Professor Marshall, for example, still does.

Mill states in set terms the Minimum Sacrifice doctrine which we noted in the last section; a doctrine springing from Benthamism, of which Mill was an exponent from within the group. "Equality of sacrifice" and "least sacrifice " are his exact phrases. Yet he is opposed to progressive taxation of incomes, which Professor Edgeworth finds to be the logical result of the Benthamite "greatest good to the greatest number," whilst accepting it for the inheritance duties he suggests.

Arthur Young's "Multiplicity" doctrine represents the extreme reaction from the Single Tax. It has found, as a rule, little favour with economists. Professor Bastable mentions ("Public Finance," p. 344, 3rd edition) Sir G. L. Northcote, in " Financial Policy," p. 309, and Mr. B. Holland in The Economic Journal, vii. p. 219-220, as supporters of the doctrine.

\section{J. S. Mill (I806-I873).}

"For what reason ought equality to be the rule in matters of taxation? For the reason, that it ought to be so in all affairs of government. As a government ought to make no distinction of persons or classes in the strength of their claims on it, what- 
ever sacrifices it requires of them should be made to be as nearly as possible with the same pressure upon all, which, it must be observed, is the mode by which least sacrifice is occasioned on the whole. If any one bears less than his fair share of the burthen, some other person must suffer more than his share, and the alleviation to the one is not, ceteris paribus so great a good to him, as the increased pressure on the other is an evil. Equality of taxation, therefore, as a maxim of politics, means equality of sacrifice. It means, apportioning the contribution of each person towards the expenses of government, so that he shall feel neither more nor less inconvenience from his share of the payment than every other person experiences from his.

"Suppose $£ 50^{\circ}$ a year to be an income ordinarily sufficient to provide a moderately numerous labouring family with the requisites of life and health, and with protection against habitual bodily suffering, but not with any indulgences. This then should be made the minimum, and incomes exceeding it should pay taxes not upon their whole amount, but upon the surplus. If the tax be ro per cent., an income of $£ 60$ should be considered as a net income of $£$ Io, and charged with $£ \mathrm{I}$ a year, while an income of $£ I$,ooo should be charged as one of $£ 950$. Each would then pay a fixed proportion, not of his whole means, but of his superfluities. ...

"To tax the larger incomes at a higher percentage than the smaller, is to lay a tax on industry and economy; to impose a penalty on people for having worked harder or saved more than their neighbours. It is partial taxation, which is a mild form of robbery.

“. . I have already suggested (Bk. II. chaps. i., ii.) as the most eligible mode of restraining the accumulation of large fortunes in the hands of those who have not earned them by exertion, a limitation of the amount which any one person should be permitted to acquire by gift, bequest, or inheritance. Apart from this, and from the proposal of Bentham (also discussed in a former chapter) that collateral inheritance $a b$ intestato should cease, and the property escheat to the state, I conceive that inheritances and legacies, exceeding a certain amount, are highly proper subjects for taxation; and that the revenue from them should be as great as it can be made without giving rise to evasions, by donation inter vivos or concealment of property, such as it would be impossible adequately to check. The principle of graduation (as it is called), that is, of levying a larger percentage on a larger sum, though its application to general taxation would be a violation of first principles, is quite unobjectionable 
as applied to legacy and inheritance duties."-J. S. Mill, " Principles of Political Economy," V. ii. § 2, 3 (I848).

\section{Thiers (I797-I877).}

" It is not true that governments should have as their chief aim, in all ages, the exemption of one class at the expense of the others; their essential objective has been to take money where it could most easily be found.

"Taxes (l'impôt) should be levied upon all kinds of incomes, on those from property as those from labour (travail).

"Taxation (l'impôt) should be proportional, and not progressive.

"Taxes should have an essential and useful tendency to become in time infinitely diversified.

"Taxes should be infinitely distributed, and should tend to become fused with the prices of things, so that each will bear his part, not in virtue of paying to the State, but in virtue of his being a consumer.

"The modifications of the system of taxes that are most desirable in the interests of the working (laborieuses) classes, are not those which are most generally proposed. . . . To diminish indirect taxes in order to increase direct taxes is not then so sure a means as is imagined of ameliorating the lot of the poor at the expense of the rich. . . . The indirect tax is rather the tax of countries advanced in civilization, whilst the direct tax is that of barbarous countries. . . .

"The Revolution, in its first innocence, shared this opinion that indirect taxes were fearsome taxes, which must be, and easily could be abolished. . .

". . . Such is the history of the suppression of indirect taxes in France: bankruptcy first of all, and the need of restoring them afterwards."-M. A. Thiers, “De la Propriété," livre iv. (I848).

\section{J. S. Buckingham (I786-I855).}

"National Evils and Practical Remedies" is a curiouslyinteresting work, describing a projected model town, of which a plan and a picture are given. The town is to be built of iron, and in the shape of a square. At the centre is a lighting tower, round which the public offices are built, forming a Forum. From this there radiate the main streets, "The Avenue of Justice," "The Avenue of Faith," "The Avenue of Peace," and so on, with streets and houses between. The factories were to be built outside the town, at a distance of half a mile. In the description of the 
community which was to reside in the model town, there is an account of its system of taxation, which contains the six rules here cited.

"To begin with an enumeration of the principal elements required in any system of taxation, deserving the name of equitable or just-with the reasons on which these requisite elements are founded. The most important appear to be these. [Reasons here omitted.]

"I. That the smallest amount of tax, consistent with the safety and good government of the State, should be taken from the people.

" 2 . That the nature of the tax should be so simple and intelligible, as that the most uninformed person who is subject to its operation can easily comprehend it, clearly understand its bearings, and give to it the full measure of his approbation or assent.

"3. That the tax should be as economical as possible in its collection.

"4. That the tax should be of a nature not to be openly or secretly evaded.

" 5. That the tax should be as favourable as possible to the consumption of these commodities which require human labour in their preparation or production.

" 6 . That the tax should bear a strict relation to the means of the individuals who have to pay it."-James S. Buckingham, “National Evils and Practical Remedies" (I849).

\section{Walras (I 834-I9Io).}

" The interests of artificial capital are inflexible and untouch. able; they always and in spite of everything escape taxation, direct or indirect. Taxes can only touch and seize upon natural wealth, rent or labour.

"... Thus complete (referring to previous exposition), the system of direct, single, proportional taxation of capital would be a very fine system. It has only one inconvenience : difficulty, nay, the radical and absolute impossibility of getting the landowners to accept it."-Léon Walras, "Théorie Critique de l'Impôt" (I86I).

\section{De Parieu (I8I5- ).}

" The true theory of taxation (l'impot) appears to us to require as its base the fixing of the sense of this rule of justice, the precise delimitation of the measure in which we can realize it, and it should then co-ordinate with this moral rule the application of the other maxims of convenience, prudence, economy, 
and humanity, which result from what we have cited above."De Parieu, "Traité des Impôts," I. iii. (I862).

\section{Sargant.}

"In all these cases there is one simple principle by which the contribution of each colonist is determined; every one pays in proportion to the expense incurred by Government in protecting him. Just as he pays the storekeeper for the goods he buys, the lawyer for the advice he asks, the ploughman for the labour he hires, so he pays the Government for the protection he receives; and the amount he contributes is not regulated by the colonist's ability to pay, but by the cost incurred by Government on his behalf. This principle has been overlooked, or slighted, in most if not all the reasonings I have seen. It has been stated, indeed, that a man pays for the protection he receives; but it has not been stated that, in the first instance, the amount he pays is only a reimbursement of the expense incurred by Government on his behalf."-W. L. Sargant, " An Undiscriminating Income Tax Reconsidered." In the Journal of the Statistical Society, I862 (p. 34I).

Professor Seligman, who quotes this, says " Sargant is incorrect in his belief that the theory had not been advanced previously (see "Progressive Taxation in Theory and Practice.") He quotes the Bishop of Llandaff as-

" the first Englishman to advance the insurance-premium theory of taxation, later on associated with the name of Thiers. He (the Bishop) states that the true principle of taxation seems to me to be this, that every man should pay for the protection of his property by the state in exact proportion to the value of the property protected; just as merchants who risk their goods on board a vessel pay an insurance in proportion to the value of the goods insured" (I862).

T. Rogers (I823-I890).

"Taxation, then, to be equitable, should be determined according to the amount of revenue which each person enjoys. What is this revenue, and to what extent is the revenue which a person receives available for his personal enjoyment? A man's revenue is not his capital but the profit on his capital. His gross wages are not his revenue. . . .

"... If we take revenue, therefore, in its strictest sense, and conceive that only to be a man's revenue which is devoted to his personal enjoyment, under the protection of the State; and further conclude that this revenue, when strictly limited in 
the sense which I have given it, is alone liable to taxation; it will be clear that the necessary maintenance of the labourer, his investments while they are being made but are as yet unproductive, and such payments as represent insurance against the risks of sickness and the certainty of death, are not legitimately liable to taxation because they are not a productive employment of his capital or labour." [This last phrase is ambiguous and unfortunate. Thorold Rogers evidently meant here by " not productive," " not productive of present income."]-Thorold Rogers, "Political Economy," XXI. (I868).

\section{§ 8. STANLEY JEVONS TO HENRY SIDGWICK.}

Writing in English we naturally, if not quite excusably, take English writers to mark our periods; but something might be said beyond reasons of pure convenience, for the names that mark off this period. In the matter of taxation, we traverse a long road from Jevons to Sidgwick. Jevons was a resolute supporter of individualism in general economics and of proportionalism in questions of taxation. Sidgwick might be conceived as ushering in the moderns. Jevons was very well satisfied, on the whole, with the English taxes of I869. Taxes are still a necessary evil ${ }^{1}$; only a minimum of financial change is needed; and as for progressive taxation, "we must beware of obeying the dictates of ill-considered 'humanity." To the last phrase, with its adjective, we shall all agree, but Jevons used it to include all graduated scales.

As we advance into the nineteenth century, and still as we enter the twentieth, the weight and body of German opinion increases. Classification of the principles of taxa-

1 It is interesting to compare the view of taxes as a necessary evil, a view once prevalent, with the following statement of $\mathrm{Mr}$. Sidney Webb, in a letter to the present writer, December, I912. Mr. Sidney Webb " doubts, in view of the very real need for increasing social expenditure in all directions, whether any one of the existing taxes in the United Kingdom is bad enough to deserve total abolition; though the selection of taxes for increase must be much more discriminating."

There is a conception of taxes here, as the parts of individual incomes marked out to be spent communally, that scarcely appeared in the earlier writers; and there is also an immediate linking of taxing and spending. Both points are characteristic of later as opposed to earlier views of the whole question. 
tion, and especially the separating out of economic from other principles, is most thoroughly done by the Germans and Austro-Germans. This is more plainly marked in the last period. We have their precursors in Walras of the last section, and in Held of this.

With Henry George we have a strong reversion to the Physiocratic doctrine of a single tax on land, but based, not on the statement that only the landowner could pay taxes, but on the argument that only the landowner ought to pay them. The land-taxes of the Budget of IgIo revived the whole Georgian discussion.

\section{Stanley Jevons (I835-I882).}

"Taking equal taxation to mean that which is proportional to income, I venture to affirm that-

"I. The available information sufficiently proves that no great inequality of taxation exists.

" 2 . The data are not accurate enough to give a sure estimate of the whole pressure on any class of people, and are therefore unfitted to form the ground of any important change in our fiscal system. . . .

" One strong assertion I can make, which is that no one can possibly prove the existence of any gross inequality of taxation in our present system."-W. Stanley Jevons " On the Pressure of Taxation" (I869).

"There is hardly any limit to the variety of difficulties and evils which may be found to result from the imposition of a tax. We may start with the concession that every tax is bad; but as we must have revenue, the question really takes the form whether one tax is bad compared with others existing or proposed. . . . A tax may be bad, then, because it is subject to-

"I. Fraudulent evasion.

“ 2. Non-fraudulent evasion.

" 3 . Costliness of collection, as regards the Government.

" 4 . Costliness to the public in money.

" 5. Loss of time and trouble on the part of the public.

“6. Interference with home trade.

“7. Interference with foreign trade.

“ 8. Unpopularity.

" 9. Incidental objections.

“ Io. Inadequacy of returns.

"It is on the ground that the labouring classes cannot be 
taxed that Adam Smith advocated the exemption of necessaries from taxation, and not on the ground of humanity or any other. But the subject is altogether a debatable one. Ricardo, in his 'Principles of Political Economy and Taxation,' controverts most of what Adam Smith said upon the subject, and distinctly states that ' his whole argument is founded in error.' "- " Principles," 3rd ed., I82I, p. 272.

"The more carefully and maturely I ponder over the problem of taxation from various points of view, the more convinced I always return to the principle, that all classes of persons above the rank of actual paupers, should contribute to the state in the proportion of their incomes. I will not say that this is a theoretically perfect rule. From feelings of humanity we might desire to graduate the rate of contribution and relieve persons who are comparatively poorer at the expense of those who are comparatively richer. But we must beware of obeying the dictates of ill-considered humanity. . . .

"... I reject then for two distinct reasons the dictum that necessaries should not be taxed. ...

"... I believe we have arrived at that point of financial reform when a minimum of change is desirable. .. .

". . . Let us for the future allow the Chancellor of the Exchequer to hold a larger surplus on hand, the produce of which will properly go towards the reduction of the National Debt, and we shall then deprive him of any opportunity for imposing new taxes."-W. Stanley Jevons, "The Match Tax, A Problem in Finance" ( $187 \mathrm{I})$.

\section{R. D. Baxter (I827-I875).}

"Modified in this sense [i.e. as against Adam Smith's explication of 'equality' as 'in proportion to income '] Adam Smith's rules of taxation may be thus expressed :-

"I. Expenditure on bare necessaries should be exempt from taxation.

" 2. Expenditure on bad habits may be heavily taxed.

" 3 . On the rest of his income every man ought to be taxed in an equal percentage.

"4. Taxes ought to be certain and uniform, not arbitrary and unequal.

" 5. Every tax ought to be levied at the time and in the manner most convenient to the contributor.

" 6 . Every tax ought to take out of the pockets of the people as little as possible beyond its produce to the Treasury.

"Such a system might produce in the three examples above mentioned something like the following results, assuming that 
the taxpayers were men of moderate indulgence in the luxuries of their stations :-

A Professional Man or Tradesman with $£ 500$

a year . $\quad . \quad . \quad \cdot \quad \cdot \quad \cdot 450$

A Workman with $£ 50$ a year. . . 3 Io

-R. Dudley Baxter, M.A., "The Taxation of the United Kingdom" (I869).

\section{Held,}

"We have thus-

"I. Generality (Allgemeinheit) of Taxation (Steuern); that is, that every one that has an income shall pay taxes.

" 2. Equality (Gleichheit) of Taxation; that is, that incomes earned in different branches of production shall be equivalently (gleichmässig) taxed without reference to their sources.

" 3 . The greatest possible consideration of the national welfare and of its increase, through a constant reference at the time (gleichzeitige) to the uplifting of the poorer classes, and to the increase of the capital of the richer classes."-Dr. Adolf Held, "Die Einkommensteuer," V. p. I2I (I872).

\section{Berthelot.}

"It is to the interest of the payers of taxes, and in conformity with the notion of the democratic state, that the whole of the public charges should be equally distributed. For this, three things are necessary: taxation (l'impôt) should be universal, should be equitably distributed, and should effectively reach the person intended."

The second of these three necessary things is described in the terms of John Stuart Mill,-the sacrifices demanded by the taxes should press equally on all citizens. Further-

"The application of the principle of equality in the distribution of taxes (l'impott) ought to lead, in the eyes of some, to proportional taxation. ... Although it seems to conform to equity, progressive taxation has been applied only rarely as yet : it terrifies the rich, whose influence still preponderates." A. M. Berthelot, in "La Grande Encyclopédie" (n.d.-end of nineteenth century).

Cliffe Leslie (I825-I882).

"And few falser maxims of finance have ever been propounded than that of the great French economist, M. Say, which Sir 
William Harcourt appears to follow, that 'the best system of finance is to spend little, and the best taxation is that which is least in amount.' On the contrary, as Mr. Wells observes in a Report on the local taxation of New York, " probably there is no act which can be performed by a community, which brings in so large a return to the credit of civilization and general happiness, as the judicious expenditure, for public services, of a percentage of the general wealth raised by an equitable system of taxation. It will be found to be a general rule that no high degree of civilisation can be maintained in a community, and indeed no highly civilised community can exist, without comparatively large taxation."-T. E. Cliffe Leslie, "Essays in Political Economy," "Incidence of Imperial and Local Taxation" (Fortnightly Review, February, I874).

Menier (I826-I88I).

"These then are the constituent (constitutive) rules of taxation (impôt).

"I. Taxation should never affect circulation (frapper la circulation).

"2. Taxes should be laid upon things, not upon persons.

" 3. Taxation should not impede freedom of labour.

" 4. Taxation should be single (umique. In the English translation of Guyot, 'Principles of Social Economy,' this is rendered as "uniform." "-VI. ii.).

" 5. The assessment of taxes should be fixed (fixe. Given in Guyot as 'certain').

"6. Taxes should be levied on the capital of the nation; every man contributing in proportion to his capital.

"7. Taxes should be stated, and not arbitrary.

" 8 . They should be levied at the time and in the manner most convenient to the taxpayers.

" 9. They should be collected as economically as possible."Emile J. Menier, "Théorie et Application de l'Impôt sur le Capital," Bk. III. chap. vi. (I874).

M. Yves Guyot, in the work mentioned above, cites these nine maxims with grave approval.

\section{Henry George (I839-I896).}

"The best tax by which the public revenues can be raised is evidently that which will closest conform to the following conditions :-

" I. That it bear as lightly as possible upon productionso as least to check the increase of the general fund from which taxes must be paid and the community maintained.

" 2. That it be easily and cheaply collected, and fall as directly 
as may be upon the ultimate payers-so as to take from the people as little as possible in addition to what it yields the Government.

" 3. That it be certain-so as to give the least opportunity for tyranny or corruption on the part of officials, and the least temptation to law-breaking and evasion on the part of the taxpayers.

"4. That it bear equally - so as to give no citizen an advantage or put any at a disadvantage as compared with others." "Progress and Poverty," VIII. iii.

\section{As for the first, he finds that-}

"Taxes on the value of land not only do not check production, as do most other taxes, but they tend to increase production, by destroying speculative rent."

\section{Taxes on land values also}

"With, perhaps, the exception of certain licenses and stamp duties, which may be made almost to collect themselves, but which can be relied on for only a trivial amount of revenue . . . can, of all taxes, be most easily and cheaply collected."

This tax also "which is the least arbitrary of taxes, possesses in the highest degree the element of certainty."

In respect of equality, Henry George criticises Adam Smith's phrase describing taxation in proportion to ability " that is," as Adam Smith puts it, "in proportion to the revenue which they respectively enjoy under the protection of the State." The objection is, that no account is taken of the differences in the size of families.

"Adam Smith speaks of incomes as "enjoyed under the protection of the State'; and this is the ground upon which the equal taxation of all species of property is commonly insisted upon-that it is equally protected by the State. The basis of this idea is evidently that the enjoyment of property is made possible by the State-that there is a value created and maintained by the community, which is justly called upon to meet community expenses. Now of what values is this true? Only of the value of land. ...

"... The tax upon land values is, therefore, the most just and equal of all taxes. It falls only upon those who receive from society a peculiar and valuable benefit, and upon them in proportion to the benefit they receive. It is the taking by the community, for the use of the community, of that value which is the creation of the community. It is the application 
of common property to common uses. When all rent is taken by taxation for the needs of the community, then will the equality ordained by Nature be attained."-Ibid.

"Our fundamental mistake is in treating land as private property." - " Social Problems," XVIII.

"The only taxes by which in accordance with the free-trade principle revenue can be raised-these two classes-

"I. Taxes on ostentation.

(An explanatory paragraph follows.)

" 2 . Taxes on the value of land."- " Protection or Free Trade," XXVI.

" But of all methods of raising an independent Federal revenue, that which would yield the largest return with the greatest ease and least injury is a tax upon legacies and successions." - " Protection or Free Trade," XXIX. note. " Progress and Poverty," I879. " Social Problems," I882. " Protection and Free Trade," I886.

Sidgwick (I838-r900).

Revenue aud Taxes-

"The chief sources [of " the material provision for the needs of Government '] are-

" (I) Rent or Interest paid by individuals for the use of wealth that wholly or partially belongs to the community.

“(2) Loans.

“(3) Payments for commodities supplied by Government.

“(4) Taxes (including tributes paid by foreigners).

"To sum up: I do not think that any sharp line can be drawn between taxes, ordinarily so-called, and any compulsory payments for services received from Government ; and I accept generally the principle of fixing the individual's contribution to Government so as to be as nearly as may be equivalent to the cost of the services performed by Government to him, so far as such services can be properly regarded as rendered to individuals. At the same time I think that this principle can rarely be applied, except in a rough and partial way, to any payments that are ordinarily called taxes." - Prof. H. Sidgwick, "The Principles of Political Economy," III. viii. §§ 3, 5 (I883).

\section{$\S$ 9. THE MODERNS.}

None of our groups have been very homogeneous : nor is this one. Adam Smith's maxims are still broadly sufficient for Colson and Stourm, whilst Wagner builds up a system of nine rules under four heads. Proportionalism and 
Progressivism are still both represented, and still unreconciled. "Boucard et Jèze" refer taxation to the conception of social solidarity, and Professor Edgeworth refers it to neo-Benthamism.

We must consider in the following chapter what emerges from the whole view : and we shall need to give full weight to these last writers, for they should show the extent of the whole advance. It is suggestive of an accelerated movement that we should have in one group, representing a period of only thirty years (I883-IgI2) the resolute Individualist philosophy of Herbert Spencer, and the expressions of social consciousness of men like Edgeworth Cannan, and Carver. There is so much varied material here that no comment can in any sense take the place of the original texts.

\section{Wagner.}

"Summary of Principles.

"I. Principles of Political Finance.

I. Sufficiency of Taxation.

2. Adjustability (Beweglichkeit) of Taxation [Elasticity].

" II. Economic (Volkswirtschaftliche) Principles.

3. Choice of the Right Sources, that is especially the discussion of the question whether taxes may be derived only from individual and national income, or also from individual and national property (or capital), and whether and how the national and individual economic (irtschaftlicher) Ustandpoints are here to be distinguished.

4. Choice of Kinds of Taxes, with reference to the effects of taxation and of different kinds of taxes on the taxpayer, and a general inquiry into the so-called shifting (Ueberwälzung) of taxes.

III. Ethical Principles (Gerichtigkeit) or The Just Distribution of Taxes.

5. Universality and

6. Proportionateness (Gleichmassigkeit) of Taxation.

IV. Administrative Principles (or Principles of Logic in the Conduct of Taxation).

7. Certainty of Taxes.

8. Convenience of the same.

9. Effort to collect taxes at the smallest possible cost. -A. Wagner, "Finanzwissenschaft," V. iii. § I26. The book 
was begun in 1877 (date of first preface) and finished in 1889 (last preface). First issue, I883-I889.

Stein (I8I5-I890).

"We distinguish these principles in their simplest form as the economic (wirtschaftliche), the financial, and the administrative (staatswirtschaftliche) principles."-Dr. L. von Stein, " Lehrbuch der Finanzwissenschaft, II. p. 353 (5th ed. I886).

\section{Herbert Spencer (I820-I903).}

" Relative ethics, therefore, warrants such equitably-distributed taxation as is required for maintaining order and safety." " Ethics," Part IV. chap. xxii.

" Property must be trenched upon for supporting those public administrations by which the right of property, and all other rights, are enforced."-Ibid.

"The amounts individually paid should be proportionate to the benefits individually received. So far as these are alike, the burdens borne should be alike ; and so far as they are unlike, the burdens borne should be unlike. Hence arises a distinction between the public expenditure for protection of persons and the public expenditure for protection of property. As life and personal safety are, speaking generally, held equally valuable by all men, the implication appears to be that such public expenditure as is entailed by care of these should fall equally on all. On the other hand, as the amounts of property possessed at the one extreme by the wage-earner and at the other extreme by the millionaire differ immensely, the implication is that the amounts contributed to the costs of maintaining property-rights should vary immensely - should be rroportionate to the amount of property owned, and vary to some extent according to its kind. ...

" One conclusion, however, is clear. State-burdens, however proportioned among citizens, should be borne by all. Every one who receives the benefits which government gives should pay some share of the costs of government, and should directly and not indirectly pay it. This last requirement is all-important. The aim of the politician commonly is to raise public funds in such ways as shall leave the citizen partly or wholly unconscious of the deductions made from his income. . . But this system, being one which takes furtively sums which it would be difficult to get openly, achieves an end which should not be achieved. The resistance to taxation, thus evaded, is a wholesome resistance; and, if not evaded, would put a proper check on public expenditure. . . . During the days when extensions of the franchise were in agitation, a maxim perpetually repeated was 
'Taxation without representation is robbery.' Experience has since made it clear that, on the other hand, representation without taxation entails robbery." - Ibid. Part IV. chap. xxiv.

"Money taken from the citizen, not to pay the costs of guarding from injury his person, property, and liberty, but to pay the costs of other actions to which he has given no assent, inflicts injury instead of preventing it. Names and customs veil so much the facts, that we do not commonly see in a tax a diminution of freedom; and yet it clearly is one."-Ibid. Part IV. chap. xxvi. Herbert Spencer, "The Principles of Ethics," Vol. II. Preface of First Edition, I89I. Issued in the Nineteenth Century, I8go (I890).

\section{Colson.}

" - it is upon considerations of equity, more or less precise, that we must depend in order to compare the different systems that may be adopted. These considerations are expressed in a formula accepted by everybody, because of its vague and elastic character: Every citizen should contribute to the public expenses in proportion to his abilities (facultés). But, first of all, how can his ability be measured, in theory, from this point of view ? Next, admitting that the best possible basis of valuation has been found, how is the practical application to be made?"

M. Colson adds to the maxims of Adam Smith, " two rules essential to the matter : fixity of the tax (impôt)"; and "the reduction to the minimum of the dead losses (pertes sèches), which are involved in it," or, as he puts the latter on another page, "reduction to the minimum of charges imposed on the public without profit to the revenue."

-C. Colson, "Cours d'Economie Politique," Vol. III. Bk. V., IV. ii. iii. (I892).

\section{Stourm.}

"To sum up, the qualities with which taxes (l'impôt) should be endowed are, as Adam Smith said, justice, certainty, convenience, and economy, to which we may add, in accordance with more recent experience, the absence of contact between the agents of the treasury and the public, an exclusive attention to Treasury requirements, multiplicity, and antiquity."-René Stourm, "Nouveau Dictionnaire d'Economie Politique," ed. Say and Chailley (I892).

In the same article, justice is related to proportionality. A paragraph heading runs- 
"First rule-justice: justice does not consist in making every one pay; it resides in proportionality" (I892).

\section{E. A. Ross.}

" To summarise, I will state the following propositions which, I believe, have been established by my reasoning.

" I. Every regularly enforced tax either produces or prohibits.

" 2 . Though obscure and hitherto little regarded, the prohibitive effects of taxation are of the highest social importance.

"3. Taxation for purposes of revenue should rest on a broad basis formed by a few orders of highly general phenomena.

" 4. These orders of phenomena should be stable and hence should include monopolised goods, the stablest orders of industrial phenomena.

"In closing, I propose that the following proposition be accepted as the canon of social economy, co-ordinate and complementary to that of administrative economy laid down by Adam Smith. A tax for purposes of revenue should have the least possible prohibitive effect."-E. A. Ross, "A New Canon of Taxation," Political Science Quarterly, Vol. VII. No. 4 (I892).

Cohn.

"It follows, from the profound revolution which has taken place in our views of the nature of the state and of the relation of national taxation (Besteurung) to the economic powers of the individual citizens, that the view prevalent to-day favours a policy precisely the opposite of what was once in favour. This, the latest view, condemns the exemption of the existence minimum at the same time that it rejects as untenable the arguments for proportional taxation. It advocates progressive taxation and holds that to be the only tenable position. Plainly, as viewed from the standpoint of the latest theory of the state, there is no room for a doctrine which admits the state and its demands only as second to the necessaries of life. The state, above all things, is part of these necessaries, and its demands are therefore part and parcel of the demands of subsistence ... from the standpoint of modern political economy, the old doctrine of a net product cannot be maintained. And therewith the doctrine of the subsistence minimum is deprived of its theoretical foundation. This defect in theory shows itself in every application of the erroneous principle. How large, for example, should this subsistence minimum properly be ? As we are well aware, it is not a physically necessary minimum."-G. Cohn, "The Science of Finance," Chicago Press translation, II. I. iii. § 222 (I895). The wording of the translation is adopted, after com- 
parison with the original- "System der National-ökonomie" (Zweiter Band, Finanzwissenschaft, §222). (Original issue, 1889.)

\section{Schäffle.}

"The so-called main Principles of Taxation. ...

"Now Taxation is-

"I. A political phenomenon, and has thus first of all a financial principle (public finance) : the imposition of the historicallycustomary demands of the state, according to a standard, in statesmanlike fashion.

" 2 . Taxation is in the second place an economic phenomenon. and has hence a two-fold economic first principle: the most complete control of the supply of commodities for the whole national economy, including public control of supply in the most economical - that is, the least costly - but most effective manner. Taxation is-

"3. A combined political-economic and financial phenomenon of income, limited to providing only for the generally-necessary part of public needs, and thence has for its third main principle the most complete political and economic development of the system of taxation as a part of public joint-income, a principle which is twofold-

"(a) The development of taxation in proper relationship to other kinds of public receipts, and

" (b) The development of the system of taxation so as to apportion the division of the tax-receipts between the different taxing authorities according to their relative needs, and to apportion as perfectly as possible, politically and economically, the joint burden of taxation between the payers according to their abilities."-Dr. A. Schäffle, "Die Steuern," Bk. I. chap. 5, § 27 (I895).

\section{Walker (I840-1897).}

" The two questions of taxation are, first, what shall be the basis of taxation ? i.e. according to what standard of capacity ; second, what jurisdiction shall exact the tax ? The ideal system is that in which persons are taxed for what they are worth, and at the place where they hold or acquire their wealth. Worth is measured by income or property less debts. The source of wealth is the place where the actual property exists, or where the person performs his labours. If we could satisfy these conditions, neither double taxation nor unequal taxation would exist."-F. Walker, "Double Taxation in the United States," chap. viii. (I895).

\section{Hadley.}

"Certainty is the fundamentally important object, without 
which all attempts at equality prove illusory. . . . If people would carry out to its logical conclusion the modern theory that taxes are a self-imposed burden, we might make equity our primary object as well as our ultimate goal. . . .

"Uncertainty may result either from failure to discover the objects which should be taxed; or from doubt as to their value ; or from the possibility of collusion between the assessor and the person who should pay the tax, by which consent is given to an unduly low valuation. To avoid the first evil, taxes should be levied, as far as possible, upon visible and tangible objects. In general, things should be assessed, rather than persons. . . .

(For the second cause of uncertainty, taxation of gross rather than net earnings, and specific rather than ad valorem duties are suggested; for the third, "it is indispensable that the objects of national and local taxation should be kept as far as possible separate from one another.")

"A tax which meets the requirements of certainty tends to become more equitable as time goes on."-Prof. A. T. Hadley, “Economics," XIV. § 500-§509 (I896).

\section{A. Wells.}

"Rules or Maxims essential to an administration of rightful taxation under a constitutional or free Government.

"First. No tax should be imposed by a state or government except by the consent of the people from whom it is to be collected, given either directly or by their authorised representatives in Congress, Legislature, or Parliament assembled.

"Second. All taxes or enforced contributions levied by the state in virtue of its sovereignty should be solely (singly) and exclusively for public purposes.

"Third. The sphere of taxation should be limited to persons, property, and business exclusively within the territorial jurisdiction of the taxing power.

"Fourth. Taxes should be reasonable, regular, and not arbitrary as respects method, time, and place of assessment, and, above all, proportional.

"Fifth. Taxation should not be employed as an agency or for the purpose of enforcing morality, or as an instrumentality for correction and punishment.

"Sixth. No tax should be levied the character and extent of which offer, as human nature is generally constituted, a greater inducement to the taxpayer to evade than to pay." Dr. D. A. Wells, "Principles of Taxation," Popular Science Monthly, March, I897. 


\section{Edgeworth.}

" The present writer has suggested, as the principle apt to be adopted by two (or, mutatis mutandis, more) self-interested parties contracting in the absence of competition, the greatesthappiness principle, slightly modified; that arrangement to be made which conduces to the greatest sum-total welfare of both parties, subject to the condition that neither should lose by the contract.... O On these and other grounds assuming the greatest-happiness principle to be the test of governmental action, let us proceed to apply the principle. The condition that the total net utility produced by taxation should be at a maximum then reduces to the condition that the total disutility should be at a minimum. From the condition that the total disutility should be at a minimum, it follows in general that the marginal disutility incurred by each taxpayer should be the same. But if the inequality of fortunes is considerable with respect to the specified amount of taxation, there will not be taxation enough to go round, so to speak. The solution of the problem is that the higher incomes should be cut down to a certain level.... [A discussion of reservations followspossible reduction of productiveness ; the question of culture ; unequal capacities for happiness; evasion.]

". . Besides the principle of minimum sacrifice, which has been considered, there are other species of the hedonic theory of taxation. The most familiar are the principles of equal and proportional sacrifice : that each taxpayer should sacrifice an equal amount of utility, or an equal proportion of the total utility which he derives from material resources.... The two species might be included in a genus termed 'like sacrifice.' . . .

". . . Is it not simpler to dismiss the deputed principle of equal sacrifice, and to adopt as the true norm of taxation minimum sacrifice tempered by a regard for the growth of wealth and other advantages above enumerated ?"-Professor F. Y. Edgeworth, "The Pure Theory of Taxation," Economic Journal, I897.

\section{Reid, H. L.}

"First in importance is the broad and comprehensive general principle-

"Canon I. Co-equal and Co-extensive Liabilities, Rights, and Privileges of Taxpayers in a Tax Area as regards their Taxation and Representation on the Councils of their respective Tax Areas. ... .

"Canon 2. Universal Tax Liability of all residing in a Tax Area, and Sharing the Benefits of Government. . . . 
"(a) Non-exemption from Taxation. . .

"Canon 3. Universal Tax Liability of all Accumulated Material Wealth in a Tax Area for Cost of Government Protective and Administrative Institutions.

"Canon 4. The Cost of Public, Protective, and Administrative Institutions for a Tax Area should regulate the amount of its Taxation; and, as far as practicable, the Cost of Protecting Distinct Classes of Wealth should regulate their respective Taxation.

"Canon 5. Proportionality in Value, Tax Rate, and Time of Possession essential in taxing Accumulated Material Exchangeable Wealth.

"Disproportional Taxation Unjust and Dangerous.

[There follows here an argument against Graduation, with quotations from McCulloch, de Parieu, Leroy-Beaulieu, Baudrillart, Proudhon, Gladstone, Thiers, Goschen, Sir L. Mallet, Fawcett, Sargant, Block, D. A. Wells, Walker, as opponents or at least not supporters of graduation.]

“Canon 6. General Exemption from Tax Charge for Government Protection of the Individual Life and Personal Rights of Members of the Community (as distinct from their Property Rights)....

"Canon 7. General Exemption from Tax Charge of the Existence Minimum and its Logical Outcome.

[To these seven Canons there are added six Maxims-]

"Maxim r. Other Advantages being equal, a Sole Direct Tax indicated as the Most Economic Method of Raising Taxation.

"Maxim 2. Taxation should not interfere with Industrial Processes, Exchanges, or other Contrivances for Facilitating the Ends and Purposes of Mankind.

"Maxim 3. Tax Laws, Regulations, and Rates should be as Definite, Simple and Intelligible as possible to all concerned. "Maxim 4. Tax Laws, Regulations, and Rates should not invite or facilitate Fraud and Evasion.

"Maxim 5. Holders of Taxable Property to be Primarily Liable for Taxes thereon, but entitled to recover from the Legal Owners Taxes paid on Property of which they were only the Bailees, Trustees, Occupiers, or Hirers.

" Maxim 6. Owners and Holders of Taxable Property justly entitled to know Total Value of and Tax Assessed on, Property of other Taxpayers of same Locality."

[There follows a discussion of "Other Maxims "-Elasticity in particular.]-H. Lloyd Reid, "The British Taxpayers' Rights," pp. 210-269 (I898).

\section{Pierson.}

"All taxes are levied with the object of providing the State 
and its subdivisions with revenue; this object must be completely attained ; there must be no annual deficit, no permanent shortage. Before this canon, which arises out of the purpose of every system of taxation, all the others must, if necessary, give way. . .

"There is a second canon to which every system of taxation should conform; it would have to take precedence of the one just mentioned, were it not that the latter too has a moral bearing. The system must be such as will obviate corruption in public life. It must give evidence of an honest striving after cquity and humanity.

"The one requirement which it must never be expected that any particular tax shall fulfil is that of being perfect."-Dr. N. G. Pierson, "Principles of Economics" (tr. by A. A. Wotzel from "Leerboek der Staathuishoudkunde," I896-I902), Vol. II. Part IV. chap. iii. §. I. Translation issued, Vol. I. I902, Vol. II. Igra.

\section{Cannan.}

"The object of every good legislature and every good Chancellor of the Exchequer is to raise the money required for government purposes, whether central or local, with as little aggregate suffering as possible. ...

"... A government which imposes a tax the bad effects of which are difficult for the populace to follow, in preference to a really less harmful tax of which the bad effects would be more easily recognised, is to be condemned, but when the effects of the taxes are equally plain to the uninstructed, the most popular will be the best. . . .

"The principle of payment according to ability, when applied to payments for certain services which cannot be divided up and sold retail to the customers, but are performed for the community in a lump, is in thorough accordance with the principle of least aggregate suffering, inasmuch as taxation according to ability practically means taxation which takes the least essential and useful part of the income of the community, as far as that can be done without interfering with production. . . .

"... So far we have dealt with economy only, but the principle of least aggregate suffering by no means excludes considerations of equity. A feeling of injustice is a form of suffering which is often acute, and may too lead indirectly, by the disturbance it causes, to more material forms of suffering. But economy must be put in the first place. The first thing to do is to find economical means of raising money. The next is to inquire if there is any ethical objection."--Professor Edwin Cannan, "Equity and Economy in Taxation," Economic Journal, Vol. XI. No. 44, pp. 469-48o, December, igor (Igor). 


\section{Nitti.}

"It is generally recognised that imposts (imposte) should have as their basis the two fundamental principles of uniformity and generality."-F. S. Nitti, "Lezioni di Scienza delle Finanze," II. vii. e. p. 259 (Ig02).

\section{Conrad.}

"From what has been said, and from a consideration of the theory of national economy, there follow, speaking generally, these chief points (Leitsätze)-

"I. There is no absolutely best system of taxes, any more than there is an absolutely best system of government. Both have to adapt themselves to the practical conditions that lie before them.

" 2 . As there is no absolutely best system of taxes, so also is there no absolutely best tax. Nor can any isolated tax be judged by itself, but only as part of a complete system of taxes, or all taxes would have been rejected, because each one has its unfavourable aspect,

" 3 . As the proportions vary, so also will the significance of individual taxes and their place in the tax-system have to change, and with this the whole system itself.

" 4. Every alteration of tax-conditions damages a number of private economies, since it calls forth dislocations in competitive relations, and hence in business affairs (wirtschaftlichen Betriebe). Hence alterations are only to be made when they are demonstrated to be necessary.

" 5. The obligation of paying taxes must be general and equal. Exemptions of individual classes or persons are to be avoided as much as possible. As such exemptions may be reckoned.-

(a) The freedom of governing classes from taxation. . . .

(b) State officials.

" 6 . The 'private-right' income of the State must, as against the community, be liable to taxes, that it may not in competing stand in a more favourable position than that of private individuals.

"7. Communities and other legal persons are to be equally liable to taxes in respect of their economic (wirtschaftlichen) profits. Institutions, however, from which private individuals draw incomes, are to be left free, else a double taxing would ensue.

" 8 . Foreigners have to pay taxes, if they live in the country, say for a year, or draw income from it in profits.

"9. Every tax prejudices the national economy (Volkwirt- 
schaft) more or less, and must consequently be limited to what is necessary. As J. G. Hoffman puts it, we must consider over every grain (Heller) of national economy, where it will be of greater advantage, in the hands of the State or in the hand of a private individual.

" Io. Taxes must only be taken out of incomes, or net proceeds (Reinertrage), else they will invade the capital stock and continuously reduce the working powers of the country.

"II. The collection of taxes must be carried out with the greatest possible consideration for private circumstances, and convenience of payment should as far as possible be furthered. Hence the lower classes must be allowed to make their payments of taxes in small instalments, the collection being first made through indirect taxes, where the taxpayer generally has to get back the advance payment. . . .

"I2. Taxes should be clearly and precisely defined, and made generally accessible to the public, so that a knowledge and understanding of them may be presumed, not only in law but in fact."-" Grundriss zum Studium der Politischen Ekonomie," III. I. i. § I7, Prof. Dr. J. Conrad (I903).

\section{Eheberg.}

"There are in particular three demands made by modern financial theories. They are-

"(I) That taxation shall be just. ...

" (2) That the taxation shall be so arranged that the least possible injury shall result to the national economy (Volkswirtschaft), in income and in property.

"(3) That the tax-system shall be so arranged, that it does in practice attain its object, providing for the expenses of the State.

"These three groups of rules may be distinguished as the principles of Justice, of Economy (Volkswirtschaft) and of Finance."-Dr. K. T. Eheberg, "Finanzwissenschaft," $7^{\text {th }}$ ed., p. I59 (Ig03).

\section{Bastable.}

" Our third rule is no other than the famous one that "taxation should be justly distributed,' a vague and plastic proposition, which we may further explain by the interpretation that it should be measured by the comparative abilities of the contributors, and this again may be taken in general to mean " taxation in proportion to income." "-Professor Bastable, "Public Finance," III. vii. § 5, 3rd ed., Igo3.

Professor Bastable gives six maxims of taxation, and in 
this order of precedence-I. Productivity. 2. Economy. 3. Equity (as above). 4. Elasticity. 5. Certainty or Stability. 6. Convenience.

\section{Boucard et Jèze.}

"Individuals should pay taxes (impots) to the extent to which they should cooperate in social solidarity. As every one ought to co-operate in social solidarity according to his powers, it is legitimate to ask from individuals a greater contribution as their fortunes are steadier and greater. Here is the fundamental financial principle on which two great theories rest : discrimination of incomes, and proportionality or progression.

"In the system of discrimination of incomes, different rules as to the rate of the impost are applied to wealth, according to its origin. Revenues of taxpayers may be separated into three classes-

"Ist. Incomes from capital. . . .

" 2 nd. Incomes from labour.

" 3 rd. Mixed incomes, from capital and labour. . . .

"The question of the proportionality or the graduation (progressivité) of taxes is more disputed. The modes of progression are numerous. Here are the chief :-

" $\alpha$. Pure Progressive systems. The taxable amounts are classed in a certain number of categories : the rate per cent. rises with the class. . . .

" $\beta$. Progression by exemption of a minimum of subsistence. ...

" $\gamma$. Progression by variation of the taxable element. The rate is fixed, and is applied only to a fraction of the taxable amounts. This is what is sometimes called degressive taxation. . . .

". . For economists, there is no contradiction in proclaiming the general rule of proportionality, whilst admitting, in a system of multiple taxes, progression for certain taxes, in order to re-establish equilibrium."--Boucard et Jèze, "Science des Finances," II. iii. I (I904).

\section{Carver.}

"If taxes were voluntary contributions for the support of the state, it would be important that we should recognise some principle by which to determine how much each individual ought to give. ... .

". . But since taxes are not voluntary contributions but forced payments, we need not so much to know what the duty of the individual is as what the duty of the state is : not how much the individual ought in conscience to give, but how much the state ought in justice to take from him, and under what 
conditions the state ought to take it. In the matter of taxation the state alone is the voluntary agent, and consequently the duty of the state alone is to be determined. . . .

"There is, of course, to be considered the direct sacrifice on the part of him who pays a tax. . . .

" But there is also another form of sacrifice quite as important and fully as worthy of attention. Any tax which represses a desirable industry or form of activity not only imposes a sacrifice on him who pays it, but also upon those who are deprived of the services or the products of the depressed industry. Taxes should therefore be apportioned in such a way as to impose the smallest sum total of sacrifice of these two kinds. . . .

" Equality of marginal sacrifice would be secured by so apportioning taxes that, as a general rule, the last dollar collected from one man should impose the same sacrifice as the last dollar collected from any other man, though the total amount collected from each man might impose very unequal total sacrifices. . . .

"As applied to incomes in general, without regard to their source, a progressive, even a highly progressive, tax will occasion, on the whole, less direct sacrifice to the taxpayers than a proportional tax. ...

"But as between different kinds of income and different kinds of property, the preference should be given to those taxes which fall upon natural products', such as land, rather than upon produced goods, and upon increments of wealth which come to an individual through natural causes over which he has no controlinheritances, for instance-rather than upon incomes earned by the individuals themselves. Such taxes are less repressive than most other special forms of taxation, and therefore occasion less sacrifice of the indirect kind."-Professor T. N. Carver, "The Minimum Sacrifice Theory of Taxation," Political Science Quarterly (Ginn \& Co., New York), Vol. I9, pp. 66-79 (I904).

\section{Léroy-Boileau.}

"We presume that all the citizens, in proportion to their incomes, participate in the advantages of government and also in the faults committed by the government, and that, consequently, they ought to pay taxes (impott) proportionally to their faculties or to their incomes. No doubt this principle rests only on a presumption ; but it is a very reasonable presumption." -Leroy-Boileau, "Traité de la Science des Finances," vol. I. p. I76, $7^{\text {th }}$ ed. (Igo6).

\section{Armitage Smith.}

"A well-ordered system of taxation should satisfy certain 
fundamental tests-the principles of justice, productiveness, economy, and simplicity....

"The canons of Adam Smith may be supplemented by minor rules, most of which readily follow as corollaries from the principles of equity and economy, and are a restatement of points which emerge from this discussion.

"(I) A system of taxation should be simple, plain, and intelligible to the common understanding, and the general incidence should be traceable with some degree of certainty. The primary necessaries of life should be free; taxation of commodities should be restricted to those which are less essential, and preferably to luxuries.

(2) Taxation should interfere as little as possible with the processes of industry ; it should fall on net income, and be such as not to check the growth of capital or cause it to migrate.

" (3) The system should provide for elasticity; that is, annual revenue should be able to be adjusted easily to annual demand. This is better attained by modification of existing taxes than by imposing new taxes.

" (4) A system combining both direct and indirect taxation is desirable, both on grounds of equity as a method of reaching all classes, and as affording various means for easy modification and ready adaptation to emergencies.

"(5) Frequent modification of taxes on commodities is undesirable, since every change creates dislocation; old taxes will have led to accommodation, new taxes will touch many interests indirectly. This has been called the canon of certainty in the form of stability."-E. Armitage-Smith, "Principles and Methods of Taxation," chap. iii. (I906).

"The first and most fundamental maxim of taxation is that of equity or justice, but the realisation of this principle of equality of sacrifice, or, rather, fair proportionate sacrifice, is difficult in practice. Even its interpretation is not easy; it is explained that each should contribute according to his faculty or ' ability to pay,' a power, however, necessarily vague and indeterminate in a complex society. That each should suffer 'the minimum of disutility' or inconvenience, that 'taxation should leave all relatively as it finds them,' are phrases more or less explanatory of the aim, and they indicate, at all events, the admission of the moral principle that justice is a prime desideratum. As a practical matter only an approximation to equity is attainable ; rough justice is secured for different classes by the adoption of a mixed system of taxation, levied in part on incomes, property, and certain actions or processes, and in part by means of indirect taxes on certain consumable articles. In its application this theory is guided by the formulation of a 
number of subsidiary and minor maxims which tend to eliminate the harshness and uncertainty of different forms of taxation. Some of these rules may be enumerated. The more fundamental are expressed in the canons of Adam Smith following that of equity, viz., certainty, convenience, and economy.

"A further principle emphasised in the British system of taxation is that necessaries of life shall be free."

[In a previous passage in the same lecture, Dr. ArmitageSmith cites as " governing principles which are recognised in the British system "- " In the first place, in Great Britain the sole aim proposed is revenue." ...

"... Again, it is held to be a sound maxim that all who have a voice in determining legislation should contribute to the cost of government ; 'legislation and taxation go together.' ']

"An important feature or characteristic of any good scheme of taxation is its elasticity."-Dr. Armitage-Smith, "The British System of Taxation," a lecture given in I9II, and published in "Lectures on British Commerce" (Igr2).

\section{Fetter.}

"Principles and Practice.

"I. Taxation should be adjusted with reference to the general social interest.

"No hard-and-fast rule for the apportioning of taxes can be laid down. The decision must be made in each generation by social opinion.

" 2 . The administration of taxation should be economical, certain, and uniform. . .

" 3 . The relation of taxation to private incomes makes it one of the largest public questions of the day."-Prof. Fetter, "The Principles of Economics" (r907).

\section{J. A. Hobson.}

" Some ' surplus ' coming as a rise of interest, profit, or wages, causes growth in the industrial structure by bringing into productive use more or better capital, labour, or ability. This may be classed as 'productive surplus.' But where scarcity enables a factor to extort a price for its use which is not effective for stimulating an increased or an improved supply, such surplus is unproductive.

Unproductive Surplus (unearned increment) Productive Surplus (costs of growth) Maintenance (costs of subsistence) . “... The Unproductive Surplus consists of- 
"(I) economic rent of land and other natural resources.

" (2) All interest beyond the rate involved in A and B.

“ (3) All profit, salaries, or other payment for ability or labour in excess of what is economically necessary to evoke the sufficient use of such factor of production.

"The true policy of public revenue is based upon the duty of the state to take as public income whatever portion of the surplus is not already allocated to the stimulation of efficiency of the individual factors of production, but is taken in rents, extra profits, or other 'unearned' income."-J. A. Hobson, "The Industrial System," Preface, chap. iv., chap. xiv. (I909).

\section{H. C. Adams.}

"Public Revenue.

“I. Direct. (a) Public Domains.

(b) Public Industries.

(c) Gratuities or Gifts, or Treasure Trove.

(d) Confiscations and Indemnities.

“2. Derivative. (a) Taxes.

(b) Fees.

(c) Assessment.

(d) Fines and Penalties.

"3. Anticipatory. (a) Sale of Bonds or other forms of Commercial Credit.

(b) Treasury Notes."

- "The Science of Finance," II. 37.

" Marks of a Good Revenue System. . . . The most important of these are as follows:

"First. A good revenue system must be adequate to the just wants of the State. . . .

"Second. The second mark of a good revenue organisation is that the financial policy of a State presents itself as a system and not as an aggregation of independent and unrelated acts. . . .

"Third. . . To speak specifically, the third mark of a good revenue system is harmony and balance between the central and local governments themselves, and between the several organs of local government."-Prof. H. C. Adams, "The Science of Finance," II. 39 (Ig09).

\section{Wicksteed.}

"There is a fairly general consensus that taxation is justified when it secures objects which the great majority of the nation considers extremely important, and which they believe would not be done at all, or would not be done adequately, if they were not done collectively. The maintenance of the army and navy, and of the police force, and the law courts, are usually 
cited as instances in point. It is generally believed that all these things are necessary to secure civilised life, and that, if their institution and maintenance had to depend on voluntary effort and combination, uncertainty as to the action of others would paralyse each man's efforts, so that nothing effective would be accomplished. These postulates are not granted by every one, and amongst those who grant them acute divisions of opinion may remain as to the extent to which provision should be carried, the amount of taxation which it justifies, and the persons from whom the taxes should be raised. As to this last point, again, it seems easy to lay down a general principle, but impossible to determine its application except by the judgment of those who apply it. The principle is that the purposes from which the resources are deflected should be as little significant or important as possible. [The italics are not in the original.] If any one thinks that the use of great wealth is usually considerate, enlightened and large-hearted, the use of moderate wealth generally sordid, and the use of small wealth vicious, his conception of the suitable sources of national revenue will be very different from that of the man who thinks that the pence of the poor usually minister to vital needs of extreme urgency, those of the middle classes to honourable ambitions and human comforts, and those of the wealthy to idle display and dissipation. The man who declines to accept either of these generalisations may regard the problem as a highly complex one, and may not be prepared with any general receipt for the application of the accepted principle. Or he may say that he does not trouble himself about the value of the satisfactions of this class or that; but he sees that some people get a great deal of what they want, such as it is, and others only a very little, and he would like to give them more even shares. This is merely the application of the general principle that the psychic significance of wealth declines as wealth increases. It is not scientifically capable of proof, but it derives strong support from common sense.

"But it may, in any case, be safely asserted that to the extent to which democratic sentiment, or an effectively democratic constitution, dominates the action of a community, the more even distribution of wealth will be thought of as a thing to be desired ; and there will, therefore, be a tendency to throw taxation upon wealth, qualified by the fear of checking the productive energies of the community; and a tendency to relieve the relatively poor from taxation, checked only by the feeling that all who have a share in controlling the public expenditure should have something directly to lose by its unwise application." P. H. Wicksteed, "The Common Sense of Political Economy," III. ii. (IgIO). 


\section{Altmann.}

Dr. Altmann arranges the four rules of Adam Smith, in modern tax-terminology," thus-

I. The furtherance of Taxation according to Ability; that is, proper assessment.

2. The furtherance of legal exactitude;

3. Convenience and

4. Small costs of collection.

-Dr. Altmann, "Finanzwissenschaft," III. 2. (I9I0).

$\mathrm{He}$ then arranges the principles of taxation thus-

I. Political-financial principles.

2. Economic principles.

(a) Tax sources.

(b) The problem of Assessment, or Shifting.

3. Ethical Principles, or Principles of Equity.

(a) Generality of Taxation.

(b) Measure and Proportion of Taxes.

-Ibid. III. 2, I (I9I0).

\section{Chapman.}

"Besides the principle of equity, other principles of taxation may be laid down. On these some comments are made below.

"The principle of economy, as it might be called, is a twosided principle which declares that, other things being equal, taxes should be chosen (I) the cost of $/$ collection of which is small in proportion to the proceeds, and (2) the loss occasioned by which to the country is small in proportion to the proceeds." -Prof. Chapman, "Outlines of Political Economy," chap. xxxii. IgIr.

\section{Taussig.}

"The first question of principle in taxation has to do, therefore, with the mode of apportionment. In what manner determine how much the individual shall contribute towards paying the various public services rendered gratuitously? Shall he pay simply in proportion to his income, or more than in proportion?...

"The conservative opinions maintaining the principle of proportion, is very simple. It proposes to call upon each person to pay in proportion to his income, and so leave the relations between different incomes undisturbed.... The essential basis for this view is that the existing distribution of wealth should not be disturbed.

"A somewhat different view, but one leading to the same 
result, is that the existing distribution of property and income should not be disturbed by taxation. If it is to be disturbed, let other machinery for doing so be adopted. . . .

" Still another ' financial ' principle of taxation may be noted ; one that perhaps should be called the cynical principle. According to this, the essential task for the legislator is to get the revenue in such a way as to cause the minimum of vexation and opposition. ... The very great part which indirect taxes on commodities play in the finances of all modern countries is explicable chiefly on this ground."-F. W. Taussig, " Principles of Economics," Vol. II., Bk. viii., chap. 66, § 2 (IgII).

\section{John Orr.}

"In matters of taxation the latter [i.e., politicians] frequently pass to the moral world for a principle on which to levy taxes. They introduce the test of fairness, and this misapplication of a moral standard to an economic subject leads to arbitrary impositions which conform with no principle. They make taxation an instrument to discourage certain indulgences. . . .

"Taxation according to moral laws is like chemical experiments according to moral laws, and the justification of science is that it makes such confusion impossible."-John Orr, M.A., "Taxation of Land Values," pp. 98-99 (rgr2).

"The economic rent or gross value of any piece of land, taken now partly by government in the form of taxes, and partly by landowners in the form of rent, is the value of public services which assist the occupier to produce wealth, plus the value of public services which provide him with a market for his produce."-Ibid. p. 58.

" A man's 'ability to pay' in the only honest interpretation of that phrase is measured by that part of the total earnings in his possession which is produced by the community, provided he is using the land in the normal or proper manner. . . . The taxing authorities should have no fear; they should trust to economic laws to bring out an equal result. There is no more just and inexorable measure of men's ability to pay than the value of land. No one can escape from it."-Ibid. p. 66. 


\section{CHAPTER III.}

\section{The First Principle of Taxation.}

I,

IT cannot be said that we can trace, in the review of opinions taken in the last chapter, any decided movement to one discernible point. In the case of the definitions there was not only an observable trend, but, for "tax" and "steuer" (we here omit "impôt"), there was a definite arrival at a common goal. Moreover, the movement quickened, and the aim became general, the goal a common one, towards the end, the most significant part of the traverse.

But had Chapter I of this book been written early in the nineteenth, instead of early in the twentieth century, there would not have appeared the same converging movement upon a commonly accepted definition. The bulk of the authorities would have proved, were a count taken, favourable rather to the view that a tax was a payment for the governmental service of protection, rather than for any alternative view. Sidgwick's definition, given in 1883 , is the earliest of those we have cited that outlines a correct definition of a tax,--correct in the sense that it will reasonably satisfy the modern economist. The middle of the nineteenth century saw us without an exact idea of the nature of a tax, and it was not until near the end of the century that we arrived at a generally accepted and standardized definition.

It does not follow that we should be in the same position, in point of time, with regard to the fundamental principle of taxation, as we are with regard to the correct conception of a tax. It is at least likely that the correct definition 
should precede the correct principle; the principle being correlated to the definition, if not actually deduced from it. Quite possibly, then, we are in the preliminary stages of a settlement as to the basic principle of taxation. That all principles and rules of taxation have not equal weight, we are all agreed, and further, that there is some real order of precedence. What is that order and, above all, what principle should stand dominatingly first in that order, we are not agreed. There are about half a dozen differing expressions of belief as to what should constitute the first principle of taxation; and that is a state of affairs that leaves us free to- conduct a fresh inquiry.

Here is a rough classification :

I. Equity (Prof. Chapman, Dr. Armitage-Smith).

Ia. Equity, translated to mean Progressive or Graduated Taxation (Seligman, Cohn; and a long list of writers, reaching back through Montesquieu to Pollux, as we have seen).

Ib. Equity, translated to mean Proportional Taxation (Colson, Stourm, Leroy-Boileau, Walker, Boucard et Jèze; together with the bulk of the classical economists of the early nineteenth century).

2. Economy (Henry George, Hobson, Schäffle (not very definitely), Wicksteed, and perhaps Wagner).

I-2. Equity and Economy as a double First Principle (Prof. Cannan),

2a. Minimum Sacrifice (Prof. Edgeworth, Prof. Carver).

3. Certainty (Prof. Hadley).

4. Productivity (Prof. Bastable).

5. Uniformity and Generality (Nitti, Conrad).

On a show of hands, it seems as if Equity would have it ; and a second vote, as between Progression and Proportionalism, would as certainly go in favour of Progression as a century ago it would have gone for Proportionalism. Yet, while we were content to accept the goal marked out by the observable trend in definitions, we do not propose to accept as a finding, that Equity, translated into a progressive scale, should stand as the first principle of taxation. This is not to reject Progression. That, as 
opposed to Proportionalism, we accept; not, however, as a first principle of taxation, but as complementary to, and indeed partly derivative from, what we are to lay down as the first principle of taxation-the principle of Economy.

In a view of the whole series of quotations, the persistence of the idea of Equity or Justice strikes our attention first. Now Justice is not an economic idea at all, but an ethical or political conception. It belongs to Political Economy, but it does not, strictly speaking, belong to modern Economics. The explorer of the regions of economic theory cannot indeed but come into contact with it, but in his domain it is an outgrowth from the neighbouring regions of ethics and politics. As a man, he is interested in it; as an inquirer into a branch of sociology, he must reckon with it, for it affects the forces with which he deals ; but as an economist, he is not directly concerned with it.

Secondly, and following from the first point, it is to be noted that economic maxims and political maxims are put together in one bundle, and that in few cases is any line of separation indicated. Thirdly, and still keeping touch with what has just been said, we may notice the curious arrest of development in the theory from the time of the issue of "The Wealth of Nations." The maxims of Adam Smith, with or without some criticism or modification, are still offered, and in the main, as he put them.

Now, if we are to follow out the line of thought already sketched in this work, we must separate pure taxes from quasi-taxes, taxes from profits, and consider more particularly what principles are to govern in respect of pure taxes, and what in respect of profits. Further, if we are to deal with economic, ethical, and political questions, we must keep these questions distinct in forming our theories, or we may quite logically be led to consider the advisability of killing off inefficients whilst considering an improved poor law designed to offer further protection to inefficients. Economically, we should gain by destroying a number of inefficients: ethically, we think we should lose through the reaction of evil moral effects. Both these ideas may be 
right, but if by confusion of thought we argue about them on a basis of mixed economic and ethical principles, we are likely to arrive at confusing or quite vicious results.

That the maxims of Adam Smith refer partly to taxation (first maxim) and partly to tax-systems (following maxims) has indeed often been pointed out (see, for example,Bastable's "Public Finance," III. vii. § 3). But in the reconstruction that follows criticism, economic and political and ethical ideas usually appear still mingled.

It will be useful to cite the maxims, canons, or principles that have so far been stated.

I. Equality (A. Smith, and others).

2. Proportionality (Walker, Boucard et Jèze, and others).

3. Certainty (A. Smith, Hadley, Beaumont, and others).

4. Economy (A. Smith, Cannan, Schäffle, and others).

5. Convenience (A. Smith and others).

6. Productivity (Prof. Bastable puts this first of all).

7. Justice or Equity (A. Smith, and practically everybody, in one form or other.)

8. Generality (Nitti, Conrad, and others).

9. Consistency (Beaumont, Kames, Burke, and others). I0A Elasticity (Bastable, Wagner).

II. Unity (Physiocrats, Henry George, Locke).

I2. Diffusion (Arthur Young).

I3. Exemption of Minimum (Bentham, J. S. Mill).

I4. Relation to Franchise ("Representation without Taxation," as converse of "Taxation without Representation").

15. Graduation (Montesquieu, Say, Seligman, and others). 16. Minimum Sacrifice (Edgeworth, Carver).

I7. Faculty or Ability (Beaumont, Kames, "Rights of Man," etc.).

The list is not complete, and of course there are overlappings, but it shows how wide a net may be thrown, if all the possible things that weigh with statesmen, with taxpayers, with officials and with economists, are to be considered. Nor has any writer claimed equivalence for the different principles he lays down. Thus Adam Smith puts certainty before equity- 
"The certainty of what each individual ought to pay is, in taxation, a matter of so great importance, that a very considerable degree of inequality, it appears, I believe, from the experience of all nations, is not so great an evil as a very small degree of uncertainty." - "Wealth of Nations," V. ii. Preliminary section.

Professor Bastable puts Productivity first, and sets the other principles in a descending scale. His arrangement springs from taking the financial point of view. He says-

"The true point of view for understanding these maxims (A. Smith's) is to regard them not as economic, ethical, or constitutional, but as essentially financial; they therefore rightly combine the different elements that must enter into problems connected with that subject." - " Public Finance," III. vii. § 3, 3rd edition.

His order consequently is : (I) Productivity, (2) Economy, (3) Just distribution ("which we may further explain by the interpretation that it should be measured by the comparative abilities of the contributors, and this again may be taken in general to mean 'taxation in proportion to income" ") (supra, §5). In an earlier chapter he says-

"The intermediate method of taxation in proportion to income is on the whole the best standard for regulation. Its true foundation needs to be carefully appreciated. It cannot claim to be a realisation of exact distributive justice; it is rather to be accepted as a convenient and fairly definite working rule of finance, or at the utmost as supplying a measure of what may be called the objective side of ability." -III. iii. § I3.

There seems to be a suggestion here that a taxpayer may be " subjectively" able to pay more than he is able " objectively" to pay, for the passage comes after an inquiry into graduated taxes; but the point is not further explained. There follow (4) Elasticity, (5) Certainty (" now requiring less emphasis "), (6) Stability or Convenience. This gradation is emphasized in a final paragraph, dealing with " a probability of conflict between the several canons." How is this to be met?"

"The plain answer is, By the surrender of the less important rule. The successful administration of the State is the final object, and therefore convenience, or even equity, may have to yield to productiveness."-III. vii. § 6 . 
There are difficulties of interpretation, as well as those of gradation. Professor Nicholson cites and discusses no less than ten modifications or interpretations of the maxim of Equality: namely,

(I) A Free Minimum Income ; Equality of Sacrifice and Progressive Taxation ; (3) Sacrifice and the Sources of Income ; $(4,5,6)$ Faculty with Nos. I, 2, 3 ; (7) Faculty and Savings; (8) Benefit Theory; (9) Social Function of Taxation; (ro) Formal Justice.

Were we concerned only with fixing the practical, fundamental maxim of taxation, we should only need to cite Professor Bastable's graded table. Certainly a tax, or a system of taxes, fails of its main objective if it is not sufficiently productive. However just, however economical, however convenient to State or individual a tax-system may be, it will recommend itself little to any Chancellor of the Exchequer if it does not bring in the amounts required. Where the maxims of taxation are set out in one general list, involving the standards of politics, ethics and economics indiscriminately, the maxim of Productivity must hold the first place. In times of stress, a Minister will not be too nice. "The State must live," will be his doctrine, and when juster taxes fail, he must fall back on some less just; when taxes " convenient " to the payers bring in ten millions he will not boggle over the adoption of inconvenient substitutes that will bring in twenty millions.

But Productivity is not a fertile idea: nothing further is deducible from it. An enthusiast for Justice might make out some sort of case to show that a just system of taxation would if its nature be convenient, or economical. Enthusiasts for Diffusion or Certainty have indeed maintained that other excellent things follow in the wake of these doctrines, and of logical necessity. But it would be difficult to make out a case to show that anything but productiveness could be postulated of Productivity. A very productive tax may as easily be inequitable, uneconomical, arbitrarily uncertain, inelastic, and inconvenient, as it may be the reverse. Very productive taxes are with difficulty brought under the other rules that have been laid down. A fundamental principle from which other generally acknowledged principles could 
be deduced, or to which, at least, such other principles could be shown to be connected, would be more satisfactorily called " fundamental " than one that stands in such isolation as does the principle of Productivity. It may well be that no such satisfactory principle has yet appeared; but at least it is quite thinkable that one may be traced that will fulfil this requirement better than that of Productivity.

Moreover, it is rather to the statesman than to the economist (as such) that Productivity is of such prime importance. Of any system of taxation, the economist's chief inquiry is, "How will it affect the production and distribution of economic goods-what will be its effect on national welfare, on the welfare of individuals, on world-welfare?" That it will bring much revenue to a governing body is not to him chiefly an end, but rather the beginning of a new inquiry -how this transfer of wealth from the control of individuals to the control of the community will affect general and individual welfare.

It is here purely the inquiry of the economist that we are following up, and from the point of view of the economist Productivity is not a satisfactory first principle of taxation. It is too infertile, and too distantly related to the questions lying at the heart of his own peculiar inquiries. Of its vast importance in statesmanship and in the administrative side of taxation, there is no question. But these things lie at the outer edges of the field of economics, not at its centre. That taxes must be raised to such an amount is a dictum of administrators. That, if raised according to such and such principles, they will have such and such effects on welfare, is a formula of economists. But of taxes levied on a principle of Productivity the economist can make no declaration at all, nor issue any dogma, so little does such a principle submit itself to the test of any of his laws.

Indeed, Productivity can scarcely claim to be a principle of taxation at all. If it means that the first essential of a tax is that it shall produce money, it is a useless truism. A wheat-farm must produce wheat: but that is not a principle of farming: it is the object of farming, as money-getting is the object of taxing. True, there may have been farming, 
and no wheat, because of the neglect of the real principles of farming. In like manner, there may be taxes levied and paid, and yet nothing come to the Treasury,- the cost of collection may equal the taxes collected, for example. The cause lies in the neglect of true principles of taxation; in this case, the principle of economy in collection.

If, on the other hand, Productivity means "very productive," it means very productive as compared to some other thing-more productive than this or that tax, more productive per head, or per sovereign of income, or per ton or gallon of goods produced or exported. Or it may mean, very productive considering how cheaply it is collected, how little it offends men's sense of justice, how conveniently it is arranged for the citizens to pay it, how little it impairs the productive powers of the nation. But this is the case : So much in taxes is to be raised, that is the object aimed at. By what principles should we be guided so as to attain that object while leaving the community little the worse for it -better, if that be possible? If to such a question we reply, "First, by the principle of Productivity" we give no guidance. That the amount is to be produced is in the terms of the question. It is not one of the guides to the solution. Reverting to our analogy of the farm, we may picture a farmer considering part of next season's operations in this fashion. "One of the things I must make sure of is to produce a thousand bushels of wheat. I want to do that according to the principles of good farming - to exhaust the land as little as possible, and even improve it if I can. To do that I must first of all consider the principle of productivity. When you want to grow a thousand bushels of wheat your chief rule is to produce them." Of course, he would not talk or think in any such fashion. He would say something like this. "Beech Close has just been down in wheat. It wouldn't do the land any good to put wheat in again, without heavy manuring. Offlands has been half in clover - the ground will be in good heart, and the other half in roots, and well cleared. That will do for wheat. And the sainfoin ley in Twelve Acres is pretty poor by now: it ought to come up. Perhaps oats would do better there, 
but wheat will do well enough. I can't think of any other fields that will suit as well. Twelve Acres and Offlands will grow a thousand bushels without very much ploughing or much manure, even in a poor season. They will do." The farmer, in fact, is guided by the principle of Economy. $\mathrm{He}$ is set his task by Productivity, but he gets no guidance from it.

By another figure, Professor Cannan expresses the barrenness of Productivity as a principle of Taxation. In a note on the subject he says. "It does not seem to me to mean anything at all more than saying that in feeding yourself the first thing to consider is the feeding properties of the food." And with that we may leave the principle of Productivity in taxation.

There is more than would appear from our quotations in support of the view of the dominance of economy as a principle of taxation, to be traced in these writers. In the first place it must be remembered that the word "economy" has generally been used in a narrow sense in this connection, as implying only cheapness of collection, or something not very much wider. It is not the word, but the thing behind the word, that is important. If we were to traverse the field over again, marking the passages in these and other writers that dwelt upon the great importance of not crippling industry, of not checking production, we should find a very notable list of writers who have given Economy (in our sense) a very important place in the rules of taxation.

In the second place, our list was necessarily made of the passages where the writers were consciously setting forth the principles of taxation, and very often they did not express under that head the sense they evinced in other places of the importance of Economy-under whatever language they expressed it. The folly of killing the goose that laid the golden eggs has often been pointed out, though there has not always been certainty as to the identity of the goose, or the acts that amounted to killing.

We do not propose to undertake the tedium of another compilation. Something can be gathered from an examination of the quotations given in Chapter II, if the idea, rather 
than the term "Economy," is held in view. Thus Held's third rule, the essence of Parnell's principle, and a great deal of the whole four rules of Sismondi, are expressions of the importance of the principle of economy; and these are but a few examples.

The support that comes from a consideration of the conclusions of political and economic thinkers, in favour of the argument here sustained for economy is thus far greater than at first appears. Had we made our choice of passages chiefly with a view to bringing out this fact, we might indeed have increased very considerably the amount of help that the argument from authority would give. This we have not done, but have made selection of those passages where the writer was laying down rules, or expressing opinions that indicate the rules he would be likely to favour. If this limitation be borne in mind together with the variant renderings by which the principle of economy, in part or whole, can be expressed, it will be found that a trend towards establishing the primacy and the clearer expression of the principle of economy may indeed be traced in the review we made in the last chapter: not a clear, obvious, or continuous trend indeed, but one quite traceable. The idea of economy was often in the minds of those who put forward the theory of " taxation according to ability to pay," which as we have seen is very odd; for the arguments given in its favour refer to the effect upon wealth as well as to notions of equity.

The varying fortunes of the principle of progression, especially in relation to the principle of proportionality, suggest a relation to political and economic changes. Graduated schemes of taxation are evidently ancient. Professor Seligman has written the history of their fortunes in "Progressive Taxation."

The laws of Solon as given in the quotation from Pollux, and the Confucian doctrine as given in Dr. Chen HuanChang's work, present the idea of progression as one of the earliest in the theory of taxation. But in the period that saw heavy taxation of the poor, often accompanied by exemptions for the wealthy, it was a reform to get taxes 
levied proportionally upon all. Later, when individualist ideas were dominant, proportionalism became a doctrine. Then the idea of progression, in modern times, came to the front again, supported sometimes on grounds of equity, sometimes on grounds of economy, but making its case good chiefly on the latter basis, often indeed as against the claim of equity as represented by proportionalism.

Whatever the phrasing used, the argument of economy has become the most effective of all arguments in discussions about taxes. Men are not indeed less quick to feel injustice, nor less eager in desiring justice, than they were in other ages : but an age of growing social consciousness has followed upon an age of individualism, and the test that is applied and accepted is a test as to the economic effects on the community. In fine, this and other changes that may be traced in the passages quoted in Chapter II. are only properly to be followed in relation to the historic changes that accompanied them, the economic as well as the political changes.

The idea that one principle of taxation may be traced and stated, which shall be so fundamental that the other principles may all be related to it, if not even deducible from it, has been touched upon before-perhaps many times. Thorold Rogers accepts Adam Smith's first maxim very much in this sense. Speaking of the four maxims, he says-

"It is plain that the division is not strictly logical, that the first of these rules is the most important, and that it virtually contains all the others. An uncertain or arbitrary tax is unequal. So is an inconvenient tax. A tax which wastes more than it gathers must affect particular persons, i.e. be partial in its operation, for were all taxation of this kind, the ends for which a government imposes and levies a tax would remain unfulfilled." -“"Political Economy," XXI.

Such an inquiry might be begun with a first selection of possible major principles from all that have been suggested, either by noting such as have been generally marked out as the more important, or by a process of elimination, where principles recognised as of minor importance are one by one struck out. Either method will make us quickly aware of 
the repetition and overlapping, the partial or debatable identity of some of the terms-justice, equity and equality for example. This difficulty might be met by grouping the whole of the terms under two or three more general headswhich may themselves be already among the terms. This should be a right method, for it is just this greater generality, this comprehensiveness, that we are seeking. We suggest that the principles of taxation that have been offered may. be put into two groups -ideas about equity, and ideas about economy.

I. Ideas about Equity.-Under this head will come most of what has been expressed by maxims concerning Equality, Progression, Proportionateness, Certainty, Convenience, Generality, Graduation, Unity, Diffusion, Minimum Sacrifice, Faculty, Exemption of Minimum Income-in so far as these are applied to the payers of taxes, and, in a less degree to the receiver, the State.

This makes a wide sweep, and it takes in much that does not lie entirely included in the idea of equity. Yet if all that is implied by that idea be removed from each of these formulæ in turn, there is not enough remaining to furnish even a moderately strong case for excluding any of them from this general heading. Most of the terms are more exact descriptions of what is to be held to constitute equitythat equity is secured if taxes be levied in proportion to income or possessions, or progressively, or upon rents only, or so as to touch the whole community, or so as to ensure a minimum of hardship, or equally-felt hardships; that it cannot be secured if taxes are uncertain, or fluctuating violently, or levied in inconvenient ways at inconvenient times. To secure equity is one of the great aims of inquirers into the nature of taxes; they express in maxims and principles how they think the aim is best to be attained.

II. Ideas about Economy.-Here come such phrases as Cost of Collection, Productiveness, Elasticity, Payment out of Income, Prevention of Smuggling.

These two groups-whatever smaller disputes might arise as to whether they cover exactly what we have put into them-suggest the idea of two principles only. To 
these principles, Equity and Economy, Professor Cannan has already reduced the various groups, ranging from Adam Smith's famous four to Wagner's nine and Garnier's sixteen. If any further simplification is advisable, it would seem as if the group under Equity, already so large, might swallow up the smaller group. But that would be to ignore Taxation as a subject for the economist, and to view it entirely from the standpoint of the moral philosopher, the jurist, and to some extent the politician. An arrangement that would drive us to view the subject of Taxation as one outside the sphere of economics would reverse the movement which has changed "Political Economy" to "Economics"; and it would be impossible, even if it were desirable, for the economist to ignore a subject so directly affecting questions of production and distribution, as does the whole subject of Taxation. We come, then, to the question, can Economy as a principle of Taxation suffice for the purposes of the economist? It is suggested here that it can.

Before we enter upon any examination of this suggestion, some consideration of the idea of Justice or of Equity will be advisable. We take Justice to imply conformity to a code, and Equity, conformity to a more general code. People say, such a thing may be legal, but it is hardly just ; and again, such a thing may represent strict justice, but it is inequitable. In both cases we refer to a wider and a presumably higher code ; in all cases there are codes of reference-statutes, common law, " unwritten law," Holy Writ, a Torah, a Koran. If any definiteness is to be given to the principle of Equity in Taxation, a code of some sort must be postulated. Thus Professor Cannan explains that by Equity we must understand what is generally admitted as equitable at the time and in the place concerned: that is, we must assume and accept the prevailing code. As Professor Cannan has brought into prominence the simpler maxims of Equity and Economy, as substitutes for the variants upon Adam Smith's maxims, it is worth while to consider the definitions of Equity and of Economy that he has accepted. "Equity," he says, "must be what is regarded as such by the mass of the people. Inequity of 
any kind will cause immediate suffering." To this he adds : "I think we are outgrowing Equity-the childish claim for a 'fair' division." At another time, speaking of Equity under the term Justice, he says, "As for Justice, the idea is rather barbarous, and we are outgrowing it." In the second edition of his "History of Local Rates in England" the precedence is definitely stated: "But of the two principles, Equity and Economy, Equity is ultimately the weaker" (chap. viii. p. I73). From this point we might begin an inquiry into the sufficiency of the principle of Economy in taxation. First, however, let it clearly be said that the field lies open for demonstrating that there are four, or two, or sixteen principles or maxims of taxation, as for demonstrating that there are two, or that there is but one. Only, it appears from an examination of the series of attempts that have been made at expressing the final principles of taxation, that not more than two, equity and economy, persist and gain in prominence.

There should be, at the least, a great likelihood of some parallel between the definition of a tax and the first principle of a tax; some similarity in the slow settling process. Taxes come into the human scheme, in the usual human unorderly manner. They come in multiplying shapes; they persist. Meanwhile, we are busy, besides paying them, in examining them, desirous of discovering their essential nature, and, next, the law of their nature. These two things should not be diverse.

Now the central fact about the definition at which we arrived was that a tax is compulsory; and we emphasised the element of force in taxes by contrasting them with prices.

Our next step is tentative, for it rests on three assumptions. Granted that we have correctly described the essential features of a tax, granted that of all the suggested maxims of taxation, only equity and economy are of prime importance, and granted that a parallel exists between the nature of a tax and its chief principle, we may come to ask this question. Given that taxation is essentially a system of compulsory payments, what chief guiding rule 
would an economist, starting from this conception, lay down as the basis of a theory of taxation: and more particularly, which of these two, economy or equity?

It must be noted that it is in the field of the economist that we are working. The statesman might be inclined to put productivity first, the administrator, convenience. According to the aim, so is the precept chosen. "Revenue duties on imports," says a modern writer (Dr. A. S. Johnson, "Introduction to Economics," I909), " are among the most convenient and popular forms of taxation, partly because the taxpayer does not realise how heavy the taxes are, and partly because of the common belief that such taxes are borne by the foreigners who export the goods" (op. cit. p. 350).

It is the economist that we are figuring as searching for the chief principle of taxation. We need not hesitate to say that he will pass by productivity (a heavy tax on water might be very productive), and convenience of payment (or of collection), and the convenient ignorance of the payers. These things he will by no means ignore : but they are not likely to present themselves to him as primary principles. As between equity and economy, we may indeed easily imagine him hesitating. These two we may more fully consider.

There is to be met at once the possibility-already suggested-of an equal primacy of these two principles: and the play of forces in the working of actual tax-systems in fact suggests a constant balancing between the two. To such an equivalence we must, in fact, recur, if inquiry fails to establish a case sufficiently strong to establish the primacy of one or the other.

It has already been pointed out that equity is less a question of economics than of ethics. Against that it must be put that the whole question of taxation is one of politics, and when economics deals with political questions, then in so far as ethical considerations arise, they must be dealt with. Taxation is an affair of citizenship, and if the economist is going to deal with citizenship, he must not assume either an economic man (or nation), or be prepared to face the 
immense difficulties of stating his case apart from such assumptions - that is, applying it to actual communities. None the less, the prime concern of the economist is not with ethics or politics, but with economics: and he will not accept an ethical or political principle before at least testing an economic one.

There is a further difficulty that arises in regard to the question of equity-the divergence in transcriptions of the term. Equity has been explained as being equivalent to taxing land values only, to proportionality, and to unproportionality-graduation; it has been translated as equality of burden, as equality of sacrifice, and as unchanged relativity. This last is usually expressed in what has been called the "leave them as you find them" doctrine, according to which equity is achieved if the taxpayers are relatively to each other after being taxed just as they were before the taxing.

And even these terms are not without their own ambiguities. What, for example, is equitable graduation, and at what angle of steepness does a scale of graduated taxes become "robbery and spoliation"? How many pounds must a millionaire pay, for each penny that his coachman pays, before he bears an equal burden, or makes an equal sacrifice?

The mere difficulty of translating a principle into actual enactments and levies, however, does not indicate any weakness or falsity in the principle: and in fact neither the strength and great importance, nor the truth and great value of the principle of equity are here minimised. But it appears that the principle of equity is difficult to translate into terms for common acceptance, that it is less an economic than a political and ethical question, and that equity is difficult to measure, chiefly because men apply different codes of measurement to it.

Austin devotes a chapter to the "Different Meanings of Equity."

"Taken in its primary sense," he says, (Lectures on Jurisprudence, Vol. II. Lecture XXXIII.) "equity, or æquity, is synonymous with universality. In which primary sense it was 
applied to the jus gentium of the earlier Roman Law, because the jus gentium of the earlier Roman Law was aquum, or common, and not restricted or particular. The jus gentium to which it was applied being distinguished by comparative fairness, equity came to denote (in a secondary sense) impartiality."

He proceeds to give five senses in which the term is used, in this order-

First: A species of interpretation " by which the defective but clear provisions of a statute are extended to a case which those provisions have omitted."

Secondly: Judicial impartiality.

Thirdly: "Frequently it signifies nothing more than the arbitrary pleasure of the judge, disguised with a name which imports praise, and which therefore is specious and captivating."

Fourthly: ". . . the standard to which, in the opinion of the speaker, law should conform."

Fifthly: " the performance of imperfect obligations."

Of these five uses, it will be seen that the first supposes some standard already fixed. The second may be a like case of presupposition; or it may fall in with the third, fourth, and fifth cases, where the standard may vary with each individual. Equity, in short, implies a standard, external or internal, fixed or fluctuating: but apart from some implied standard, it has no meaning whatever.

Concerning Justice, Austin in the same work (Lecture VI. Note on Hobbes' proposition that " no law can be unjust ") :

"For just or unjust, justice or injustice, is a term of relative and varying import. Whenever it is uttered with a determinate meaning, it is uttered with relation to a determinate law which the speaker assumes as a standard of comparison. This is hinted at by Locke . . . ; and it is, indeed, so manifest, on a little sustained reflection, that it hardly needs the authority of that great and venerable name. By the epithet just, we mean that a given object, to which we apply the epithet, accords with a given law to which we refer it as a test. And as that which is just conforms to a determinate law, justice is the conformity of a given object to the same or a similar measure. . . . Though 
it signifies conformity or nonconformity to any determinate law, the term justice or injustice sometimes denotes emphatically, conformity or nonconformity to the ultimate measure or test: namely, the law of God. That is the meaning attached to justice, when law and justice are opposed: when a positive human rule is styled unjust. And when it is used with this meaning, justice is nearly equivalent to general utility. ... And hence it arises that when we style an action just or unjust, we not uncommonly mean that it is generally useful or pernicious."

Here again, as in the case of the word Equity, the fact emerges that apart from some standard, some "ultimate measure or test," some code, there is no meaning in "justice" or "injustice." Three possible standards are outlined in the passage quoted:-

(a) Positive Law - a definite code previously constructed by men.

(b) The Law of God, either as conceived in the hearts of men, or as expressed in words in a definite moral code.

(c) Public Utility, as judged in the time and place where the action to be assessed as "just " or " unjust" is considered.

There can be little question that of these three the last is the most proper to an economist. But what then must he mean by Public Utility, and wherewith shall this test be tested? Public Utility, to him, must be tested in terms of goods, or of goods and services; of economic wants and their satisfactions; of things made and used; of the Production, Exchange, Consumption and Distribution of wealth. And if he is inquiring of a tax, whether it conforms to the principle of justice, that is, in further rendering, to the principle of public utility, will not his first inquiry be whether it is wasteful in its action, whether it hinders production, misdirects consumption, obstructs exchange, alters distribution for the worse, or otherwise-in a word, whether it conforms to the principle of Economy? If then, by beginning with the principle of Justice, he is led along this path, only to begin his actual test, as Economist, with the principle of Economy as his " ultimate measure and test," 
why should he not take the simpler and directer road of beginning with the principle of Economy rather than with the principle of Equity or Justice?

. If we turn from rigid legal definitions and conceptions to some wider and more human view of what is justice, we are by no means led to an opposite or very different conclusion. Shelley's famous definition, in the "Essay on Christianity" is a true poet's definition of justice-not at all a definition of poetic justice.

" This, and no other, is justice. To consider, under all the circumstances and consequences of a particular case, how the greatest quantity and purest quality of happiness will ensue from any action, is to be just, and there is no other justice. The distinction between justice and mercy was first imagined in the courts of tyranny. Mankind receive every relaxation of their tyranny as a circumstance of grace or favour."

(The semicolon and the "and" inserted after "action" by the editors of Shelley are here omitted.)

This is no narrow legal definition, but rather anti-legal, and wide enough to include the idea of mercy. How will it read, if the economist paraphrases it into his own terms, taking just such applications of its general bearing as are appropriate to his case ?

"This, and no other, is justice. To consider, under all the circumstances and consequences of each social or political act, how the greatest quantity and purest quality of satisfactions of wants will ensue from it, is to be just, and there is no other justice."

But, in his own language, the economist is in the habit of calling this "economy," and not "justice." We deal with words chiefly to get at the things behind the words, and the thing here, on the economic plane-the essential thing that matters, is the satisfaction of wants, the production, distribution, and consumption of utilities.

It would seem, unless our reasoning has been quite wrong, that Economy must take precedence of Justice in the matter of taxation, because it is the more vital thing, and because it is the higher and the bigger conception. 
II.

We are constantly inclined to accept traditional standards without question, and the more fair-seeming they are, the more unquestioningly we accept them, despite the reminders we so often give each other- "All that glisters is not gold," "Appearances are deceitful," and so forth. And among other things, we accept too readily, too unquestioningly, the idea of Justice. It may indeed be assumed that the idea of Justice is among the highest and noblest of human ideas; that it may be applied to all human relationships; that the application is equally fit and equally appropriate in all cases. But the assumption may be challenged. Consider one application, one that covers a wide field in the domain of economics. By what scale or standard, at best, should we regulate payments? Should men be paid according to work done (however the work may be measured), or should they be paid in accordance with their needs, irrespective of the actual work done, though quite possibly with an eye to the effects upon work to be done? The principle of Justice, in itself, and in its usual application, would suggest "equal pay for equal work" rather than payment according to need. Yet if we would make more possible the highest rate of production, if we would strive for the most generally satisfactory scheme of distribution, if, in brief, we would be advised by the best thought of modern economics, we should choose rather a system of payment according to need ${ }^{1}$; and in choosing it, we should be guided, not by the principle of justice, but rather by Sir Philip Sidney's dictum, "Thy need is greater than mine," translated from the moral to the economic sphere; by the family law that gives food first, not to those who have laboured most, but to those weak or sickly ones that have not laboured at all-by the principle, not of justice, but of economy. As in the sphere of morals

1 "Nothing in economics is more certain than that the best distribution-the distribution which makes a given amount of produce go furthest-is distribution according to need."-Professor E. Cannan, Economic Journal, September, 1908. 
mercy stands higher than justice, so in the sphere of economics, the principle that we have named Economy avails more than the principle that is called Justice. Should we deal out to individuals a little more justice, even though the community be benefited less, or should we rather withhold that little more of justice, that the community may be benefited more? The quantitative values of the question appear. Yet, broadly, it is certain that we are inclining more to the latter way. The claims of justice, from " eye for eye and tooth for tooth " doctrines to the milder modern readings, appear cruder to our eyes as the centuries pass, and the older Law makes way for newer Gospels-_ " Justice " for " Mercy," " Payment according to Services " for " Payment according to Need." This may be the wrong path, but it is the path we are treading, however slowly; and slow movements have sound human forces behind them. Of these two doctrines of taxation, Justice and Economy, Justice is not the higher, but the lower; not the more conducive to the effectual satisfaction of wants, but the less; not the surer guide to a more stable distribution, but the less sure; not the nobler, but the savager.

Let us keep clearly in mind what it is just now that we seek. We have concentrated our attention on two principles of taxation that by general consent, open or implied, are of chief importance; and we are inquiring whether of these two one is dominant, when they are both viewed from a standpoint that is, on the whole, the standpoint of the economist. We have considered some of the bearings of the principle of equity. Let us turn now to the principle of economy.

A tax being by nature a compulsory payment, not crediting the payer with any definite claim to proportionate benefits, what implications are there in the use of "economy" as a principle to a payment of such a nature? We must take a wide reading of " economy" if we have any thought of adopting it as a prime principle of taxation: economy first of all to the community, next, to the individual, and finally, to the governing power. Of these, the first will call for general treatment. The other two are more special 
cases, except where they are dependent on the first. We will take the cases in reverse order.

Economy from the point of view of the governing power will mean economy of administration, chiefly with reference to collection. It will call for a swift and simple means of obtaining such sums as may be needed, by some system elastic enough to respond to possible increases of demand without any considerable increase in the difficulties of obtaining the money required. It will call for a system that needs a minimum of the machinery of collection, that calls forth a minimum of remonstrance, resistance, and evasion, and keeps at a minimum the inevitable effect of every taxing - that it makes further taxing so much less possible. There are included here large portions of the maxims of convenience and elasticity, with some portion of the maxim of certainty.

Economy in taxation from the point of view of the individual payer is not altogether to be separated from economy as affecting the cornmunity, or even the governing power. But there belongs to it the rule that if the State demands so much from ten million payers, then each one shall actually pay his one-ten-millionth, or whatever fraction is apportioned to him, and little or nothing more. An import duty of 7 francs the quintal of corn, says M. Charles Gide (" Principes d'Economie Politique," II. IV. vii., Ioth Ed.) will bring to the State 70 millions of francs, but the individual buyers of corn will pay 560 millions of francs more than they would have paid had there been no duty. Here the supersession of the principle of economy, as touching the individual payer, converts a tax payment to the State of I franc to a tax-payment to the State and others of 8 francs-the State taking only the I franc, and, let us say, a few centimes per franc for the cost of collection.

Taxes will be "economical," from the standpoint of the individual, if they leave untouched his working capital, his health and efficiency-items of income, the pounds or pence that are spent in making him more efficient; if, further, the taxes are collected at what time, in what manner, and at what place is most convenient to him, and if he 
may reckon, with sufficient certainty, the amounts that will be required of him for some time ahead.

But economy to the community will include the economies secured to the individual payers. It will chiefly express itself in securing that the productive powers of the community are left unimpaired, and that any tendency to an increase of the powers of production is, if checked at all, then checked as little as may be. Good taxes, that is, will take from the community, since take they must, what the community can best spare. If it be urged that the taxes taken from the community are yet taken by the community and for it, then we must repeat that in so far as some equivalence of return is to be reckoned on, it is prices or quasitaxes that are in question. We deal now with pure taxes, that have no reckonable counter-payments. The pure tax is to be considered in relation to the principle of taxation, and it is of taxes that are taxes and no more that we must now concern ourselves.

We propose to continue the argument by an analogy, and we will leave aside for a moment, both the claim that all argument is by analogy, and the oft-repeated warnings against the danger of argument by analogy. When we have set out our parable, we may then consider how far its findings may with safety be applied.

We take the case of an overlord who is levying a mantax-that is, raising a force of infantry for war. He demands of a husbandman one of his sons, and after the preliminary grumble (silent or expressed) which the vassal, like the modern income-tax payer, holds to be the natural prerequisite to taxpaying, the third son Harold is offered.

"Take Harold," says the vassal, " he will be as useful to you as any other, and I can spare him best. He will fill out a buff-jerkin, wave a billhook, shout, stand or march as well as another. He will make one of a line to hack and be hacked as prettily as most. If you were to take Edmund, now, I should lose my right hand, and you would be no better off, for he would be no more useful to you, either alive before the battle, or dead after it, than Harold. The gain of him or the loss of him would be much the same to 
you as the gain or loss of Harold. Not so to me-nor to the farm, nor to you, my lord, when the time came to pay your dues. Take Harold and leave Edmund, and I can pay you as much corn, perchance, as ever. Take Edmund and your dues next year will bite us harder, and perchance you will see us pressed so that dues must be lessened, or the ground be worse tended. I will not ask you to take Oscar either. True, he is little use to me yet, for he is young. But for that also would he be of little use to you. He stands for the bigger crops of later years, and for your dues from them. Have an eye to those years, my lord, and do not waste them in advance by taking Oscar now. Little is the benefit you will get from him this summer, if you take him to battle, and he is slain, or crippled, or kept too long from learning good husbandry; and much is the loss that his spoiling will secure for you in other years. Then take Harold, my lord. That will be wise, and good husbandry, and more convenient to us both. It will be a thing of more justice to me, and to the land, and to yourself : for it will be good economy in all ways."

The overlord, since we have supposed him tolerant enough to listen to this long speech, may perhaps be pictured as explaining to his vassal that he must not forget that protection, law and order, were given in return for such levies as this, and further, that the levy was justly made, at the rate of one man from each family, or from each hundredacre holding, or according to some fixed standard. To which the vassal may be allowed to reply.

"I know you levy justly, my lord, as between vassal and vassal. That is no doubt of some comfort to me. Yet my loss is no less a loss because my neighbour is in no easier a case. The chief thing is, I am to lose a son. What if my neighbour also loses one-what even if he loses two ? My loss remains. As for your protection, and the law and order you administer for us, lord, what you say no doubt is true. But do I get more protection and more order now that I give more? If you come next year and levy two sons, shall I have twice as much protection as this year? It does not work so. How much or little I pay 
you does not settle how much or little protection I shall have. For ten years I did not pay you in sons, and yet I had as much protection as I am like to have this year. Yet how much or little I pay does very straitly settle how much or little I am hurt. Here is something to measure your levy, lord, and by this I measure it. Take your levy, lord, so that the land and those that farm it are least hurt."

We take this to be sound sense, and we trust that the lord chose Harold, for the interest of lord, vassal and community would thereby best be served. And further, we think the case appropriate to modern conditions, except that the difficulty of choosing between Harold, Oscar, and Edmund becomes, to the modern State, the difficulty of choosing between one shilling and another, one trade or property and another. If the analogy has any force it drives straight to the idea of economy rather than to the idea of justice, as the dominant principle. We have represented the vassal as concerned primarily with the most economical way of paying a one-man tax, from the point of view, not only of himself, but of the lord. We have of course made him say the thing that fits the theory suggested; but that is not fatal to our argument if the thing said is the likeliest thing to be said, and if it lies close to the shrewdest and frankest thing a man in such case could say. Supporters of the doctrine of Justice, or of any other doctrine, may paraphrase the vassal's speech, basing it on some other first principle. Should one such paraphrase be likelier, wider, truer to the facts of life, then whatever is here based on the speech as given will be struck out of the inquiry. For the present, we will assume the soundness of the case as we have put it.

\section{III.}

In acts of exchange, in purchases, the first consideration of the buyer is to get full money's worth ; of the seller, to get full price. It is these price-payers who take justice as the first principle for appeal. "You do not offer a just price," "You do not give just measure," are their plaints. "A fair bargain" is the ideal openly accepted by both. A 
belief that the bargain is on the whole fair is necessary for the existence of future bargainings. It is for the priceelement in taxes that the citizen chiefly (not entirely) demands justice-justice first of all. Is it not then likely, since he makes payments made of two elements-tax and price, since he asks for two principles to be consideredjustice and economy, that as one claim, justice, is in the main for the one element, price, so the other, economy, may be chiefly for the second element, tax? We must not assume too much at this point, nor accept so apt a symmetry because it is a symmetry. The formula is neat and exact-

$$
\left\{\begin{array}{lllllll}
\operatorname{Tax} & \cdot & \cdot & \cdot & \cdot & \cdot & \cdot \\
\text { Price } & \cdot & \cdot & \cdot & \cdot & \cdot & \cdot
\end{array}\right.
$$

but its very neatness should make us cautious. Symmetry is suggestive rather than conclusive.

We have alluded to the possibility of some connexion between the definition and the chief principle of a tax. Our definition has partly rested upon the antithesis of tax and price; and we have just been considering a like antithesis in relation to the fundamental principle of taxation. For a price there is a definite measured return offered, and the chief concern of the payer is that he should get just measure,justice (expressed as equivalence) being the first principle to which he will appeal. For a tax there is no definite measured return offered, and no choice as to payment. Here there is no question of just measure, for the immeasurable is dealt with. Only justice as between one sufferer and another is in question; "I am hurt, why should my neighbour be less hurt? True, if he is equally hurt, my injury is none the less, but I am not galled by a sense of unfairness." This is scarcely ground on which to build a first principle. Rather is it, " Since I must be hurt, and take my chance of what benefits may accrue, having no guarantee that for half hurts I shall have half benefits, for doubled hurts double, then let my hurt be as little as may be, let the community as well as me, be mulcted of the necessary amount with as little damage as possible." 
We will adventure another analogy. The chief priest of a nation declares that the Gods demand the yearly sacrifice of a thousand oxen. The nation is a small one, the demand relatively large. One of the elders asks if any particular kind of oxen is to be offered, and is answered that to the Gods all oxen are indifferently oxen. Again the elder asks if the Gods will be offended if some old or sickly oxen are offered, and is told that all oxen are oxen, but there must be a thousand offered annually. Upon this the elder counsels the sacrifice of the thousand sickliest, oldest, most wretched oxen in the State. That the full thousand must be offered to the last one, he is firm ; but the Gods are willing that in paying the tax the community and its members shall be harmed as little as possible. It is his duty, as an elder, to advise that this shall be done. But now, if in the selection of the thousand it appears that of two men, each with four oxen, one has three poor and sickly, and the other but one weakling, is the first man to yield three oxen and the second only one? There will be something else to considerjustice as between man and man. But economy was the first consideration. The sacrifice is made, we will say, upon these lines-an economical selection of the poorest beasts modified by arrangements to prevent such hardships upon individuals as in the case cited. The constant effort to select as many as possible of the poorest oxen will ensure that the bulk of the thousand will be those that the State can best spare : and will probably also entail a certain amount of resentment on the score of injustice, even when modifications to meet the claims of justice have been made-since these fall in a secondary place. Had justice been the first consideration, less grumbling would follow the taxing, but there would be a larger proportion of the better oxen in the thousand chosen-that is, the total tax would be larger. If justice as between individual payers is to be put as a first principle of taxation, the community as a whole will suffer more from the tax. If the community is to suffer as little as possible from the taxing, then economy must be first considered. A choice is offered between hurting the community a little more, while annoying it a little less, and hurting it a little 
less, while annoying it a little more. If the term "annoying " appears unduly mild to represent a greater amount of injustice, we must recall that justice is a thing measured by arbitrary and changing standards, whilst a shilling paid in taxes is relatively fixed.

The problem is not unlike that presented by the choice between direct and indirect taxes, when the latter take the form of protective duties. We can figure a statesman weighing the economic cost of an import duty on corn against the outraged feelings of a people suddenly called upon to pay the whole of their own taxes instead of " making the foreigner pay " part of them-omitting, for the sake of our argument, all other issues and complications. Men's sense of justice, however inaccurately developed, is too mighty a force for the statesman to ignore. It cannot but be seriously reckoned with by the economist: but the economist, in such a question, can scarcely give it first place.

It is time we gave some consideration to the word economy. It was originally household-law, or house-ruling (oîkos, vómos), and came to mean careful management-which is complimentary to the world's housewives. It does not properly mean frugality, still less parsimony.

"Economy," says Crabb, in his "English Synonyms," " implies management ; frugality implies temperance; parsimony implies simply forbearance to spend. . . . By economy, a man may make a limited income turn to the best account for himself and his family."

Economy, in fine, is not limited spending, but wise spending, profitable spending. We might, indeed, speak of unwise spending as bad economy, and wise spending as good economy. But in that case we should not speak of Economy as a principle of taxation, but "Good Economy." This is scarcely necessary. We may thank the housewives for the good odour in which they have left the word, and understand by Economy, not management good or bad, but good management only. We may yet say "Good Economy" instead of merely "Economy" where ambiguity is likely to occur. 
The principle of Economy is not to be confused with the idea of retrenchment, as implied, for instance, in a oncefamous cry, "Peace, Retrenchment, and Reform." For retrenchment, in itself, may be the worst economy. It is sound economy to abstain from any expenditure, in order to make a more profitable expenditure-perhaps immediately profitable, perhaps more remotely profitable, a proper discounting for postponement being reckoned in. It is not sound economy to abstain from expenditure where the alternative use of the money saved is less profitable. A workman's wife who saved five shillings a week out of the family food-bill would in most cases find it impossible to make a better use of the money - the total loss would far outbalance the total gain. She would not have observed the principle of economy, but rather have flouted it.

"In current language," says Philip Wicksteed in "The Common Sense of Political Economy," " "economy' means the administration of any kind of resources (time, thought, or money, for instance) in such a way as to secure their maximum efficiency for the purpose contemplated" (pp. I3-I4).

"Economy," says Professor Cannan, " . . . being, of course, understood not in the vulgar sense of spending little, irrespective of the return to the expenditure, but in the sense of the best utilisation of available means."- " History of Local Rates in England," 2nd edition, chap. vii. p. I60.

Nor are we straining the word to use it in this sense, for this is practically how most people would define it under any pressure as to exactness. "Very bad economy that, spoiling the ship for a ha'porth of tar" is a common criticism of short-sighted parsimony. We will take Economy to imply, then, the best-known distribution of expenditure for the satisfying of wants.

What is implied, then, when we put Economy forward as a principle of Taxation? Not at all the collection of the smallest possible amount of taxes, but the wisest method of collecting them. As for the amount, there can be no rule as to upper or lower limits. It may be wise to collect a hundred millions in a certain way, and unwise to collect ten shillings in another. The considerations that should decide 
the amount raised are not governed by the magnitude of the amount, nor even by the proportion it bears to the total national wealth or income. We cannot here entirely separate the influences of expenditure from those of revenue, but we may lay down some guiding rules.

I. If the community receives on the whole greater benefit from payments made as taxes in any form, than it would receive if the amounts had remained in the hands of the payers, the principle of Economy has been observed in the whole matter of public taxing and expenditure.

II. If the productive power of the community is on the whole greater when taxes are paid than if those taxes had not been collected at all, then the principle of Economy has been observed in the taxing.

III. If the productive power of the community is on the whole the same after as before the payment of taxes, again the principle of Economy has been observed in the taxing.

[Expenditure is omitted in II. and in III.]

IV. If the productive power of the community is on the whole less after than before the payment of taxes, then the principle of Economy has not been observed unless-

(a) the loss to the community is adequately made up by a corresponding gain in the manner of the State expenditure of the money received, so that in the whole matter of taxing and expenditure the community is at least no worse off than if there had been no taxing (I. above); or,

(b) the loss is the least possible in the circumstances then existing.

We may get a step nearer to definiteness if we set out our findings as to the implications of the principle of Economy, which will form a re-statement of what we have just expressed.

(I) Taxes should not cause or intensify any change to less economic methods of production, but should either give an impulse towards better methods, or preserve the status quo in this respect.

Thus,

(Ia) Taxes should not cause population to be distributed 
so that the work of producing utilities would be carried on under less favourable conditions.

(Ib) Taxes should not encourage the development of any industries which, without the taxing, would have been less developed, or not at all ; since the industries which would otherwise have taken their place would, by the terms of the argument, be more productive, because more naturally favoured. But yet each industry must be considered not only in itself, but as part of the whole life of the community. If then certain industries so affect vitality, intelligence, and initiative as to impair the whole productive power of the community, then these industries, though favourable in themselves to the production of certain goods, may yet be discouraged, even on purely economic grounds, by taxation as by other methods; for if the loss caused by such check be more than counterbalanced by the total gain in productivity, by the principle of economy, the check would not only be excusable, but advisable. If also certain other industries are highly favourable to the development of vitality, intelligence, and initiative, but are at an economic disadvantage, they may be favoured by being taxed less in proportion than other industries, if, firstly, the total gain to the community more than counterbalances the total of the taxes lost, and if, secondly, no better method than by taxation is available.

The case just cited is " on the fine edges of things." It would call for very careful handling in actual treatment, and in the rough movements of political action it would more likely than not become an argument for establishing vested interests on the plea of public utility. It is doubtful if any experiment in this direction has ever been made that has not yielded more bitterness than satisfaction, more ill than good. But it is necessary to insert it here to complete our argument. The former of the two cases, which would apply to dangerous occupations, excessively-exhausting conditions of labour, and child-labour, is not so open to dangers of exploitation: yet it also lies within clear limits, as we have stated.

2. Taxes should not alter the Distribution of capital or 
income so as to induce a diminished productive power ; or, if they must, then as little as may be. Where possible, they should alter Distribution so that a higher productiveness may result. This is a far cry from the rule, so commonly laid down in the eighteenth to nineteenth century period, that taxation must not alter Distribution at all; and the whole question that it brings up is so important that we will deal with it at some length.

The older position has been definitely stated in several forms, many of which have been cited in Chapter II. The clearest form is what is called the " Leave Them As You Find Them" doctrine, definitely expressed by James Mill.

" A tax, to operate fairly, ought to leave the relative condition of the different classes of contributors the same, after the tax as before it."-"Elements of Political Economy," IV. viii. (1826).

If, indeed, the distribution of wealth in a community were the best possible distribution for the purposes of production, or were moving quickly in that direction, then the "Leave Them As You Find Them" doctrine would be effectively the same as that at which we have now arrived-that taxes should not alter the distribution of wealth so as to cause a diminution of productive power. Something like this was in fact assumed by earlier writers-a system of unchecked competition would tend to transfer wealth to the most productive channels, and into the most productively-capable control. But no such view is held to-day.

"The older economists," says Professor Marshall, "took too little account of the fact that human faculties are as important a means of production as any other kind of capital; and we may conclude, in opposition to them, that any change in the distribution of wealth which gives more to the wage-receivers and less to the capitalists is likely, other things being equal, to hasten the increase of material production, and that it will not perceptibly retard the storing-up of material wealth.""Principles," IV. vii. § 7 (I907).

In a more recent work still this passage occurs.

" No one has any real doubt, however he may measure wants, that wants are nothing like so unequal as wealth at the present 
time, and therefore no one can doubt that the present power of production would go much further if purchasing power were more equally distributed : hence the almost universal acquiescence in the provision of elementary education at the expense of taxpayers, and in progressive taxation. Measures adopted to produce greater equality are, however, exceedingly unsuitable for local authorities."--Prof. Cannan, "History of Local Rates in England," I9r2 edition.

Many similar expressions of opinion might be cited, but they are not necessary. We may take as agreed-

(I) That the present distribution of wealth is not the best available distribution for the purpose of securing the greatest possible power of production, or the most general satisfaction of wants.

(2) That uncontrolled economic forces might or might not tend to high productivity, but it is only for speculative purposes that they are worth considering. There has always been legislative control, and all present indications point to more control, rather than to less.

(3) That economic forces, working within the controls that have so far operated, have not given us what can be accepted as the best distribution for high productivity. How near an approximation they have made is a matter of opinion and debate.

(4) It is therefore quite possible that the distribution of wealth could be readjusted-apart from all other considerations-so that a higher productivity would result.

(5) This readjustment might be effected, among other methods, by means of taxation.

We are brought now to consider this question-Does the principle of Economy guide us to a scheme of taxation devised to secure such a distribution of wealth (income or property) as will lead to higher productivity?

Broadly, we may say that the plain answer must beother things being equal, yes. But other things are here, as usually happens, not equal. In this case they are to be summed up under two main heads, the fallibility of governmental schemes, and the right limits of taxation as an agent of social and political change.

Firstly, then, as to the fallibility of governmental schemes. 
However completely it may be granted that the distribution of wealth may conceivably be altered at any given time by suitable taxation, it does not follow that such suitable taxation is known and at hand. It may be, but there is no inevitableness. A score of governments may embark upon a score of schemes with such an end in view, and some, quite thinkably, may find they have altered distribution so as to lessen productive power; others, that they have affected productivity very little; others again, that they have, as they projected, increased production. The present distribution gives a certain degree of productivity; any scheme for altering it would divide men into those who were for bearing the ills we have and those who are ready to risk others that we know not of. The subject is wide enough, and important enough, to be considered and discussed in itself ; we cannot properly give it adequate discussion here. But if the principle of economy be established as a first principle of taxation, then such an inquiry would immediately become as pressing as it is important. For the present we must be content to note that if the present distribution of wealth is not satisfactory, then a "Leave Them As You Find Them" doctrine could not be satisfactory either, except on the grounds that we are next to examine.

Secondly, we are to consider the right limits of taxation as an agent of social and political change. It may be related to our present purposes in this fashion. Even if it be granted that Economy should stand as the fundamental principle of taxation, and that a scheme of taxes could be designed to secure economy by furthering productive power by the method of altering distribution in the direction of greater equality, is taxation the proper road to such social changes? Should not taxation be for revenue only?

The answer is twofold. In the first place, it may or may not be illegitimate, or unwise, or socially dangerous, to accept as a doctrine that social and political changes may properly be achieved through taxation. But whether that doctrine be wise or unwise, it does not follow from the principle of economy. What does follow is that taxes should be so levied as to increase productivity where possible, or 
to diminish productivity as little as possible. If it appeared that an increase of productivity would follow on a widening disparity of incomes, the principle of economy, in itself, would point to a scheme of taxation likely to make incomes less equal than they are. The objective, from the point of view we have taken, is not an altered distribution as a good thing in itself-whatever opinions we may have of thatit is how to collect taxes without checking production, to collect them, if possible, and at the same time increase production. Most people would agree that a greater equality of incomes than that now obtaining in England would be a good thing in itself. But so much is not required, in order to satisfy the principle of economy. It is only required that taxes should fall so as to increase productiveness, if possible; and it is generally allowed that if they do not leave people as they find them, but leave them with incomes something more equal than at present, productiveness is likely to be increased. How far the process could be carried, short of arriving at absolutely equal incomes, is a speculative question for us, and may be a practical one for our successors. That there are limits, we know, but where they are set we do not know. It is arguable that there is no limit but that of equal incomes. What is plain is that the "Leave Them As You Find Them" doctrine is untenable at this point in the world's history, at least ; and the doctrine of Proportional Taxation, consequently, must be abandoned. When property and income are so distributed that any change of proportions would be likely to lead to less productiveness, then the principle of economy will point to Proportional Taxation, and Chancellors will be counselled to leave people as they find them. But we need not stray so far into the future.

In the second place, we may be advised to note that taxation should be for revenue only. This can only be taken as a counsel of perfection, according to the views of the counsellor. For it is very difficult indeed to levy taxes for revenue only. Tariff Reformers desire to get revenue from customs duties, and at the same time to make the foreigner pay, or to encourage home industries, or to bind the Empire 
more closely. Duties on alcoholic liquors are not regarded from the point of view of revenue only, but ideas of general social welfare are expressed by those who would make them higher, and by those who would put them lower. Land Taxes are advocated because they will help to create a race of small holders, and create a " back to the land " movement. "Taxation for revenue only" should mean taxation with no motive but that of attaining a sufficient revenue. But our other motives can only be indifferent to all but the revenue coming from our taxes, if revenue is the only effect of the taxes. It is because one tax, producing a million, does not cause as much waste or so great a sense of injustice as another, producing as much, that we adopt it. If we truly taxed for revenue only we should be quite indifferent as between the two. We shall raise the revenue in any case: what in truth chiefly concerns us are the effects of raising it. The "Effects of Taxes" is the most vital question of all, and the chief effects are economic. The principle of economy is concerned with these very economic effects. All that is valuable in the doctrine "Taxation for revenue only" is secured by the principle of economy, or nearly all. What is desirable is that taxes should be levied

(a) without checking Production;

(b) without any avoidable waste;

(c) without arousing an effective opposing force, e.g. a sense of injustice;

(d) without encouraging social evils.

If social weal is encouraged, or the sense of justice satisfied, or waste eliminated, or production increased, so much the better. There is no likelihood of our arriving at them any the quicker by taxing for revenue only.

But we may not go further. It is one thing to choose our taxes and to distribute them so that there may be social and political gains as co-products or by-products. It is another thing to choose taxation mainly or chiefly as a means of reform. It is indeed a very potent weapon of social change, and there appears no good reason why it should be neglected. But it will always be open to question and debate, when any tax is recommended because of its 
social or political effects, whether a better result could not be obtained by other legislative methods. Opposition to such a recommendation, however, should be by way of showing that other methods will be more effective in bringing about the change, or that the change itself is undesirable, rather than by reference to so barren a formula as " Taxation for revenue only."

The proper function of taxation is certainly to bring in revenue; but that statement helps us little. When we come to the real question, how to tax to get the revenue, we are in nowise helped by any such formula.

\section{IV.}

The case for Proportional Taxation, as we have seen, rested on the assumption that the existing distribution of wealth was the best possible, or at least steadily moving in that direction; and it falls with the assumption. Indirectly, then, we arrive at Progressive or perhaps Degressive Taxation. ${ }^{1}$ But the case for Progressive Taxation has two direct and practical bases-the actual practice of modern governments, and the developments of the theory of diminishing utilities.

We are not now concerned with the case for or against Progressive Taxation in itself, but in relation to the principle of Economy. That principle would guide us to collect taxes from those incomes, or parts of incomes, of least utility to the community or to the individual. The least useful parts are the last increments, and it is here that a strict observance

1 According to the following plan:-

A. Proportional Taxation, where all incomes are taxed at the same rate.

B. Progressive Taxation, where the larger incomes are taxed at a higher rate.

C. Regressive Taxation, where the smaller incomes are taxed at a higher rate.

D. Degressive Taxation, where incomes below a fixed amount are exempt from taxes. The remainder may be taxed on A, B, or C scales. 
of the law of diminishing utility would direct us, on grounds of economy alone, to levy all our pure taxes (for rules about progression or proportion are rules of pure taxes). But this is more than progression : it is Procrustean taxation. If the ten richest men in a nation had each an income of half a million a year, then the most economical method of raising a million pounds in taxes would be to tax each of them to the extent of $£ 100,000$, and exempt the rest of the community. The "top" or least useful part of their incomes would be removed, since that part is not only the least useful to them, but is, on the average of men, less useful than any parts of lower incomes. Thus in the case given in the tables of the next few pages, if we separate out all incomes into $£$ I0o parts, so that the $£ I, 000$ incomes are divided into ten parts, and considered as being made up of successive $£$ roo increments-first, second, third hundreds, and so with all other incomes, then it is plain that the "last" £roo of a man with $£ \mathrm{I}, 000$ a year is the least valuable of his ten hundreds: far less valuable to him than was the first hundred, when, as we may suppose, that was his sole income, and far less valuable to him than is the single hundred of a man with only one hundred a year. The first hundred of every one in the table may be taken as of equal value to the possessors, and of equal value to the community. We cannot reckon on their being otherwise, until we know of the various uses to which the different holders will put them. We are not justified in assuming that men with incomes of $£ \mathrm{I}, 000$ a year are wiser or less wise in the use of their moneys than men with a hundred or men with a million. The "tenth hundred" of men with $£ \mathrm{I}, 000$ a year will be of equal value then, as far as we know, to the different individuals, and equal also to the tenth hundred of each of the men with $£ I 0,000$ or $£ I, 000,000$ a year. Of all the separate $£$ roo parts of income in the country, then, the least valuable are those ten that carry the incomes of the richest individuals from $£ 900,000$, to $£ I, 000,000$. These then offer themselves first for taxing, and next the hundreds between $£ 800,000$ and $£ 700,000$, and so on. 
Incomes

in $£$.

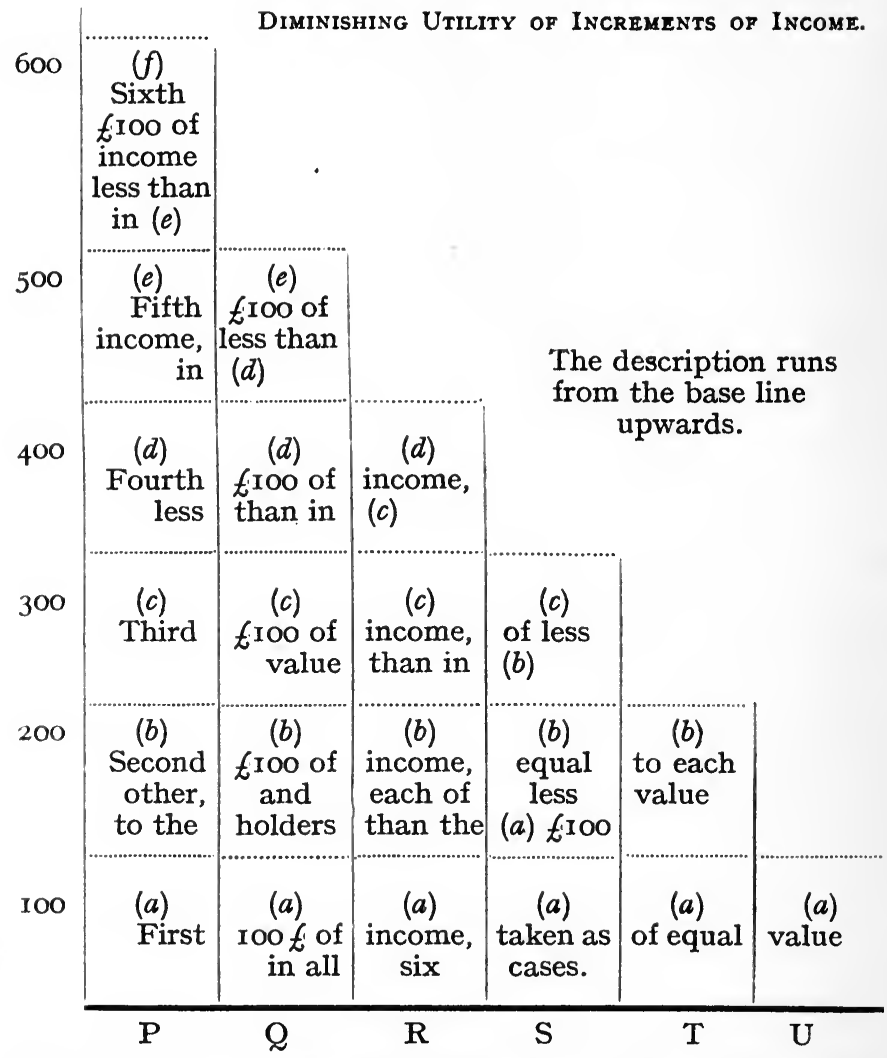

$P, Q, R, S, T, U$ are six persons with incomes of $£ 600, £ 500$, to $£ 100$ respectively. Each income is divided into $€$ Ioo parts.

For social value, there is this to be considered, that there are kinds of productive work that men having incomes of $£$ Ioo cannot carry on, and that men with incomes of $£ I, 000$ are able to undertake. Against this, again, must be offset such methods as that by which large operations, like those of the Co-operative Societies or Joint-Stock Companies in general can carry on by means of many small portions drawn from small incomes.

Since, however, all "first hundreds" must be taken as equal in value to each other, all " second hundreds" as of 
less value than " first hundreds," but of equal value among themselves, and so on, then, in order to take as little of total values as possible from the nation, we should begin by taking in taxes the whole of the one-hundred-thousandth hundreds, of which there are only ten in the case cited in our table, and then the ninety-ninth hundreds, and so on, until the whole amount needed has been collected.

If we are desirous, however, that all the citizens shall pay some taxes, or at least all above a fixed arbitrary incomelimit, then by beginning at the other end, with the low incomes, we shall get a progressive scale. We may build up scales like this-

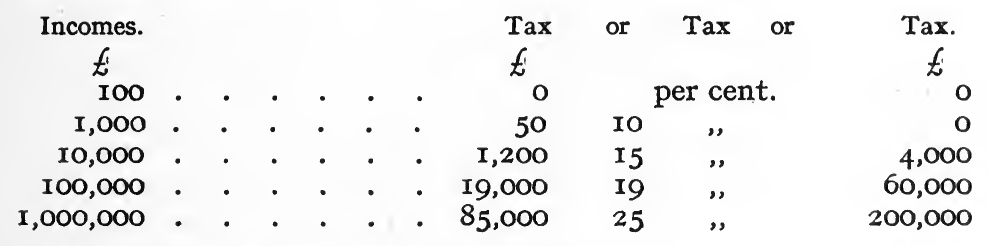

The figures or percentages are arbitrary. But they are none the less arbitrary, though they may satisfy the eye better by their symmetry, if they run in some such fashion as this-

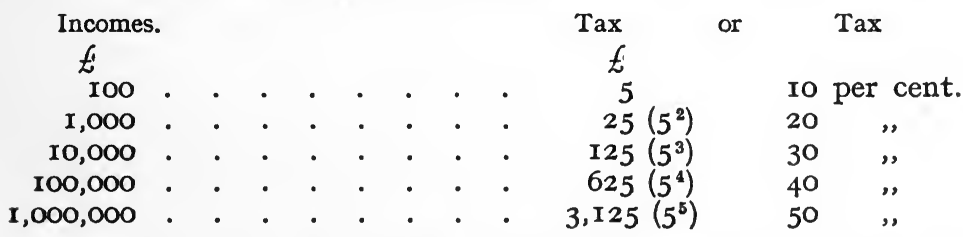

All progressive scales, built up from the lowest incomes, or from the lowest incomes taxed, are based upon an arbitrary sequence of numbers or percentages, whatever may be the symmetry of the sequence adopted. So long as we are thinking of economy only in relation to taxes clearly paid according to income, we must begin by considering parts of incomes, and take the least useful parts. And that method will drive us to begin with the largest, and not with the smallest incomes, in framing our scale.

We can, indeed, by disregarding persons for a moment, and considering parts of incomes only, such as " hundreds," 
say that a man with $£$ I0,000 a year, say, shall pay taxes in this fashion-

On the first hundred

$\begin{array}{ccccccc}£ & \text { or } & £ & \text { or } & £ & \text { or } & £ \\ 0 & & 0 & & 1 & & 2 \\ I & & 2 & & 2 & & \\ 2 & & 3 & & 3 & & 6 \\ 3 & & 4 & & 4 & & 8\end{array}$

and so on, so that his total payments will be made up of different amounts paid on the different "hundreds" according to their utilities. But still, the scale that relates the different hundreds is an arbitrary one. By the scale of the first column he will pay $£ 4,95^{\circ}$, by that of the second, $£ 5$,I49. But these scales, taken with "fifties" instead of with hundreds, and running as $I, I \frac{1}{2}, 2,2 \frac{1}{2}$. . instead of $I, 2,3$, or $2,3,4$, would give us different results with an equal symmetry. We do indeed get a method that is based upon the different values of different increments, and that is a theoretic gain from the point of view of economical taxing ; but even if we know that the tenth hundred should pay seventeen pounds, or should pay 5 per cent., we cannot deduce from that the percentage or the amount that is proper for the eleventh or the ninth hundred. The table just following will show how rapidly such a simple scale as I per cent., 2 per cent., 3 per cent., etc., passes the roo per cent. line.

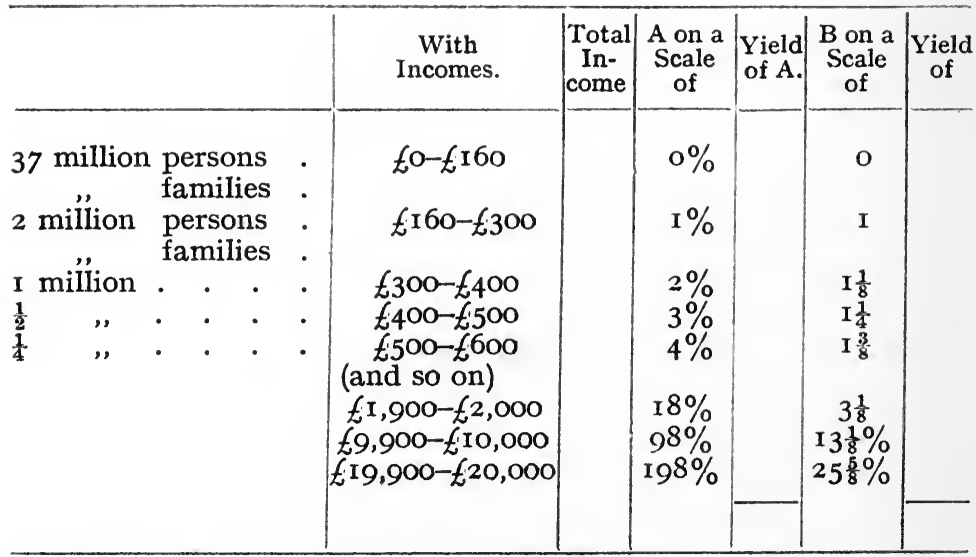

The difficulty can be met in three ways. The first is that 
of a more gradual progression, as in the B column, where, by beginning with o per cent., I per cent., as before, we proceed by increments of $\frac{1}{8}$ per cent, for each $£$ Ioo of income, reaching only to $13 \frac{1}{8}$ per cent. as against 98 per cent. for the corresponding income on the $0, \mathrm{I}, 2,3,4$, plan, and $25 \frac{5}{8}$ per cent as against 198 per cent. The second method is by extending what we have already done in leaving the first two steps (o per cent. and I per cent.) untouched; which is, passing from one scale to another as we proceed. Thus we may combine several scales into one, producing, as it were, a flight of steps where at every few steps the step-height is diminished, after this fashion :-

What we get is a flattening curve, tending to become horizontal :- 
on, we could build up some such compound scale of percentages as this :-

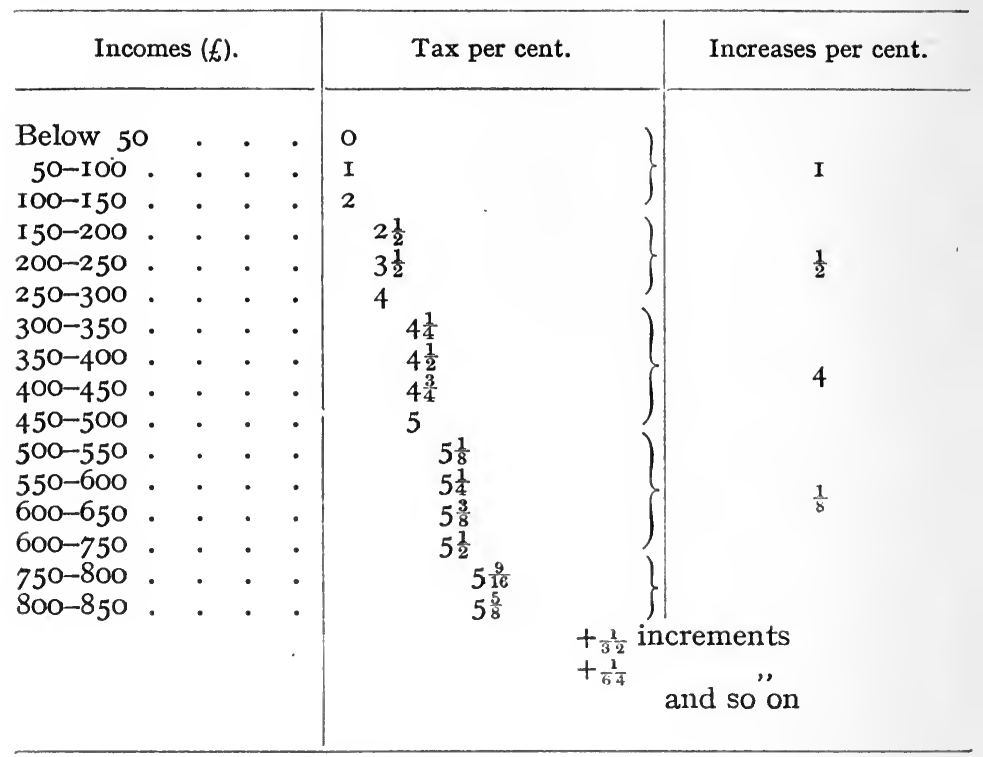

The third method, which is practically that adopted for the English Income Tax, is to apply the plan of variable steps to incomes as well as to increments of percentage to be paid, but in reverse order. The actual steps, in incomes, are-

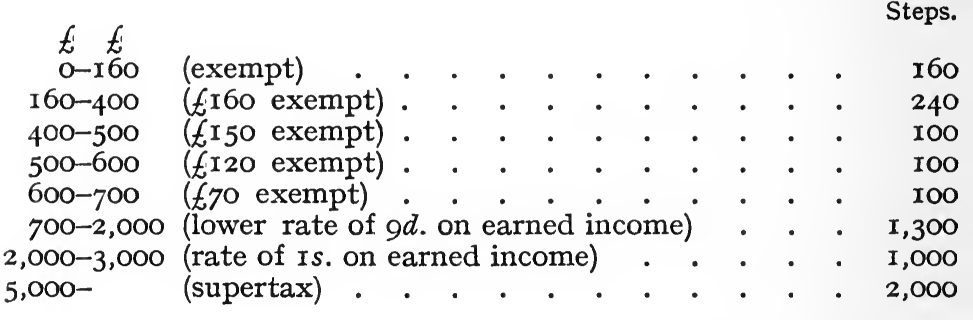

The graduation of percentage rates is arrived at indirectly in the case of Income Tax, but directly in the case of death duties. In both cases, the amounts assessed are graduated, and there is a tendency to make this, rather than the per- 
centage payable, the chief means of graduation. Thus in the Estate Duties we get amounts from $£$ I00 to $£ 3,000,000$ arranged into 25 groups, separated by somewhat erratic steps of amounts from $£ 500$ to $£ 500,000$. The percentage rates, however, form a simple series from I to $I 5$, with " arrests " at 6, 7, 8, II, I2, I3, I 5. In the case of the Income Tax, the scale offers itself at first, as a non-graduated scale of Is. $2 d$. in the pound; but by exemptions, abatements, differentiation for earned and unearned incomes, and supertax, a practically graduated scheme is built up, ranging from an actual charge of about $I \frac{3}{4} d$. in the pound on earned incomes between $£$ I60 and $£ 200$, to about Is. $7 \frac{1}{2} d$. in the pound on incomes of $£ 50,000$ and over.

The English " "Death Duties."

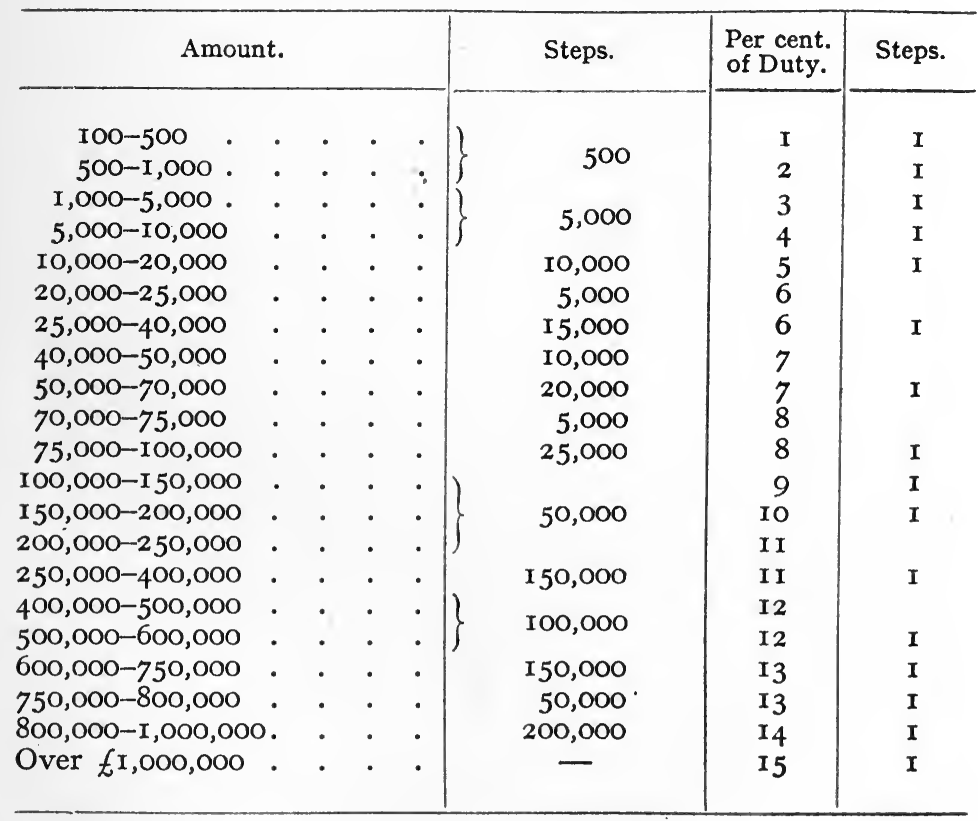

V.

It would seem as if the consideration of other things than economy brings us to some point of compromise be- 
tween proportional and progressive taxation. But in fact it brings us to a progressive scale somewhere between proportional taxation and that Procrustean taxation which we have just outlined as ideal from the point of view of economy alone. The table which follows illustrates this. Taking a sum of about $2 \frac{3}{4}$ millions sterling in taxes, we have a view of how it would be collected according to a proportional scale ; how it is collected on the scale of the English Income Tax and super-tax (the numbers here are rounded off, and the total also, for convenience), and how it might be collected on stern economical Procrustean lines

(Numbers rounded off.)

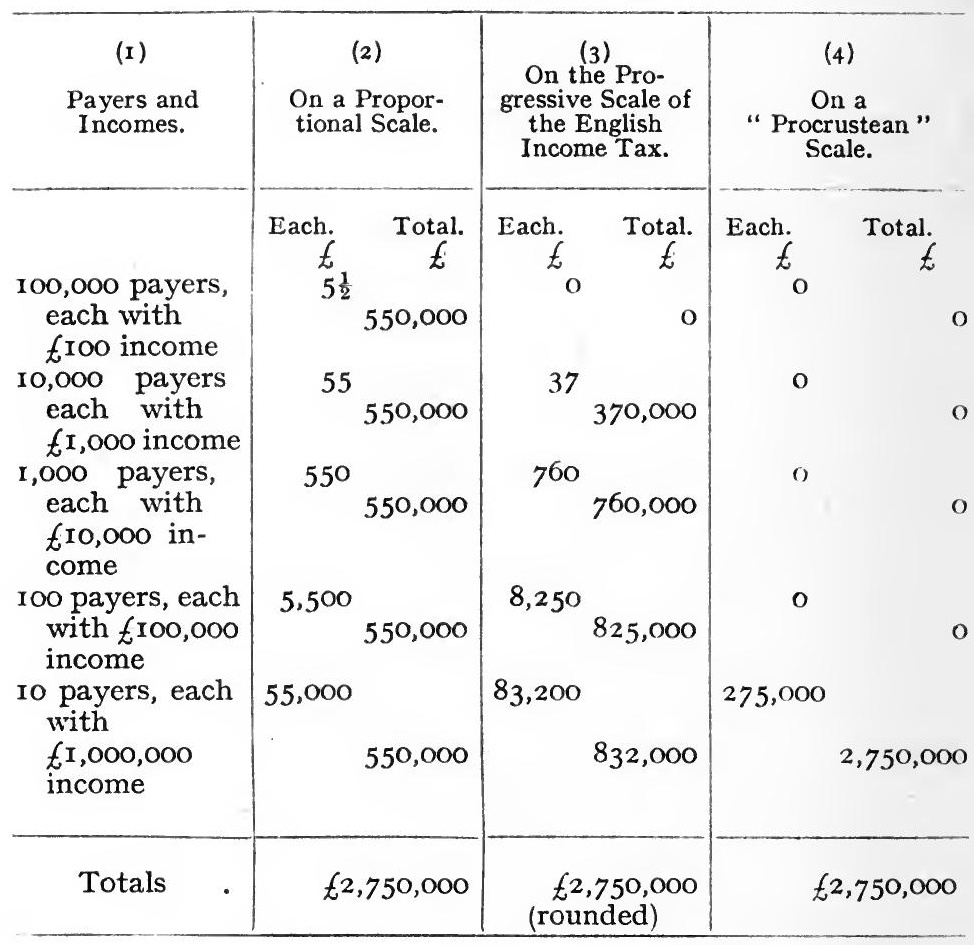

(It must not be inferred that English taxpayers at present pay their contributions to State expenditure on the scale given in column (3). It is Income Tax that is paid on such a scale) 
Of course, if the "Procrustean" scale (4) were actually applied, it would only be effective for one year. The ten people with incomes of a million would dispose of some of their wealth to relatives, or adopt other methods of avoidance. "Procrustean" taxation is a distant and apparently inaccessible point marking the direction rather than the goal of our movements. The distinction between "long run" and "short run" effects, pointed out by Professor Marshall, applies to many aspects of taxation. Generally speaking, it is economy in the long run that is desirable, and where there is a choice between a scale or system that will be in agreement with the principle of Economy in the long run, and another that is in agreement with it only for a short run, the former is to be preferred. Nations can take a longer view than individuals, and generally speaking, we should always understand the principle of Economy to be understood as meaning that the effects, in the long run, are economical.

The conclusion to which we come, through following up solely the principle of economy, is that at which Professor Edgeworth arrives in following up the principle of Minimum Sacrifice ("The Pure theory of taxation," Economic Journal, I897). Now the principle of Minimum Sacrifice is absolutely an economic principle. It may be, and indeed is debated in connection with ideas of justice. The approach, indeed, is rather from the side of moral philosophy, of ethics, than from the side of pure economics. Professor Edgeworth presents the doctrine of Minimum Sacrifice as a deduction and rendering drawn from Bentham's " Greatest Happiness of the Greatest Number." There is no need for us to accentuate the difference between the line of approach we have followed, and that which begins with "Minimum Sacrifice" or "Greatest Happiness." The two lines of reasoning converge to the same point. The implication is that the principle of economy may find confirmation from other principles based on ethical or metaphysical or political grounds; that in seeking economy we may also be fulfilling some of the requirements of justice. It would be easy to overstate this part of the case: for the present, no more 
than the implication, or suggestion, may be assumed. The argument might be driven so far as to present the principle of economy, not only as the first, but as the sole principle of taxation. For such a claim, indeed, a very good case could be made out. When lines of argument that begin with Economy and with Minimum Sacrifice converge upon the same finding, a strong presumption is established that the ethical and the economic principles are expressible in one law. But our findings so far do not warrant so much. We shall be content to establish, as well as may be, the claim of Economy to be the first principle of taxation, leaving the question of its completeness and exclusiveness to be dealt with after more evidence, and more discussion. At least it becomes evident that the principle of economy covers a wide area.

A full consideration of the principle of Economy should deal with its content, its implications, and the complementary principles that it requires. With the content of the term we have already dealt, and we have considered its main implications. We have not yet mentioned what has often been taken as the chief implication of the principle -relatively small cost of collection; nor have we dealt with smuggling or other evasions. These are indeed important subdivisions of the principle of economy, but although the older writers considered them as practically expressing that principle, they are subordinate to the great question of raising taxes by the most economic method, i.e. collecting in taxes the money which can best be spared. For this reason we put them last, and not first. But the order in which they would stand in a system of taxation would depend on their relative quantitative importance at any given time in any given system. There have been times in the history of nations when the discouragement of smuggling was a very great part of the principle of economy, and the prominence given to the question by some of the older writers was justified by the facts about them. Also, a very admirable system, conceived with a view to checking production as little as possible, but allowing great opportunities for evasion, would quite possibly result in the revenue being largely 
obtained from moneys that were on the whole more useful to the community and to individuals than from other moneys that escaped. Nevertheless, the chief implication of the principle of economy, in general statement, is that the money should be collected, beginning as far as possible with the least useful parts of incomes: small cost of collection and relative freedom from smuggling are on the whole minor implications.

We are able now to make a fuller statement of the implications of the principle of economy. They are-

First. That taxes should be obtained from the least useful parts of incomes.

Secondly. That taxation should not encourage less productive methods, occupations, distribution of population, distribution of property or income: but, if possible, the reverse. [This is not altogether separable from the first implication.]

Thirdly. That the cost of collection should be as low as possible; for this cost must be included in the total taxes raised, and whenever it is reduced, some income is set free that is presumably more useful than any of the parts of incomes still paid in taxes.

Fourthly. That a tax-system should encourage or allow as little smuggling, fraud, or evasion, as possible : for presumably more useful parts of incomes will be taken to supply the deficiency.

\section{VI.}

There is a question that naturally arises, in making choice between the principles of equity and economy in taxationis not some harmonising possible, whether by the statement of a third term which shall include sufficient of both these, or by any other method? The weakness of the principle of equity or justice has been dwelt upon; but it is apparent that this very weakness in some degree attaches also to the principle of equity, in every case of actual application short of our "Procrustean" scale.

Some such harmonising is in fact possible. The parallel 
of the two following phrases $((a)$ and $(b))$ brings out its extent and usefulness.

(a) Taxes should be levied in the most economic manner, regardless of all other things than the possibilities of acceptance at the time and in the country where the adjustment is made.

(b) Taxes should be levied in accordance with the idea of justice prevailing at the time and in the country where the adjustment is made.

It may be urged that either of these rules would give much the same result. So much we are not indeed prepared to accept, but it must be conceded that the divergence would not in all cases be very great. There are limits to what any community will accept and act upon; but the limits that would be marked out, with Economy as an instrument, are not identical with those marked out by Justice. In short, Justice (or Equity), and Economy are not identical terms, and however nearly two nations might approximate in actual results to the same system, though one began with Justice and the other with Economy, yet that is no argument sufficient to persuade us that the two are equal in value. Of two different principles offered it is likely that one is better for certain purposes than the other-little or much. It is extremely unlikely that their values approximate so closely as to make a choice between them a matter of indifference.

It will have been noticed that we constantly refer to taxes in relation to income, and to direct taxes upon income as if typical of their kind-as indeed they are. In their effects, practically all taxes are "income taxes,"-that is, they resolve themselves into payments made out of income. The Death Duties are largely paid out of income, and the Exchequer makes arrangements to facilitate this manner of payment. The Income Tax is the typical tax. When we consider the great opposition that this "odious tax" aroused, 1 and consider also its steady and remarkable

${ }^{1}$ Dr. Slater reminds us that in 1816 "The Whigs had even succeeded in obtaining excited meetings against the Income Tax among Wiltshire labourers, who were perhaps earning $6 s$. a week.- "The Making of Modern England," p. 18. 
growth, the present general acceptance of it, the substitution of opposition to its amount and distribution for the former opposition to its nature, and to its very existence in time of peace, we may feel justified in concluding that a change in our ideas of the nature of taxation has accompanied this change in our tax-system. We saw, in reviewing the definitions of "tax" "steuer" and "impott," that in France the conception of the nature of taxation had not moved to the same point as in England and Germany. The two things (ideas of the nature of taxes on the one hand, and the development of an income-tax on the other) may not be connected, but it is at least curious that there has been no development of income taxes in France at all like the movement in England and in Germany.

Our own figures are remarkable. To get a proper picture we should need to set out in one column the return from Income Tax, with or without Estate Duties (they are for most purposes of this kind better put together), and the total returns in another, for each year from I843. Then we should need to mark the "war-periods," and all circumstances likely to affect the changes in the amounts or proportions. But when all allowances are made the growth is very considerable. It is shown in the following summary, where the figures are rounded but without any falsifying of the rate of growth.

1844 to 1853 (before the

Crimean War)

War period, I 855 to 1858

1859

I 860 to $1864^{\circ}$. . .

I 865 to 1869

I 870 to 1879

1880 to 1889

1890 to 1899 (Boer War)

1900 to I9II-I2

\begin{tabular}{|c|c|c|}
\hline $\begin{array}{c}\text { Total } \\
\text { Revenue. }\end{array}$ & $\begin{array}{c}\text { Yield of } \\
\text { Income Tax } \\
\text { (" Property and } \\
\text { Income Tax"). }\end{array}$ & $\begin{array}{l}\text { Proportion } \\
\text { from Income } \\
\text { Tax. }\end{array}$ \\
\hline Million $£$. & Million $£$. & $\begin{array}{l}\text { Nearest simple } \\
\text { fraction. }\end{array}$ \\
\hline av. 56 & av. $5 \frac{1}{2}$ & $\frac{1}{T_{0}}$ \\
\hline $\begin{array}{l}70 \\
66\end{array}$ & av. I $3 \frac{1}{6 \frac{1}{2}}$ & $\begin{array}{l}\frac{1}{6} \\
1 \\
1 \\
\text { Tó }\end{array}$ \\
\hline av. 70 & av. Io & $\frac{1}{7}$ \\
\hline av. 70 & av. 7 & $T^{\mathrm{i}} \tilde{\omega}$ \\
\hline av. 70 & av. 7 & $\frac{1}{10}$ \\
\hline av. 86 & av. I3 & $\frac{1}{7}$ \\
\hline $\begin{array}{l}\text { av. I05 } \\
\text { av. } 58\end{array}$ & - & to \\
\hline & a. 34 & 20 \\
\hline
\end{tabular}


THE NATURE OF TAXATION.

\begin{tabular}{|c|c|c|c|c|c|c|}
\hline Year. & $\begin{array}{c}\text { Total } \\
\text { Revenue. }\end{array}$ & $\begin{array}{c}\quad(b) \\
\text { Net Produce } \\
\text { of Property } \\
\text { and Income } \\
\text { Tax. }\end{array}$ & $\begin{array}{c}(c) \\
\text { Ratio } \frac{b}{a} \\
\text { Nearest } \\
\text { Simple } \\
\text { Fraction. }\end{array}$ & $\begin{array}{c}(d) \\
\text { Net Pro- } \\
\text { duce of } \\
\text { Property } \\
\text { and } \\
\text { Income } \\
\text { Tax and } \\
\text { Estate } \\
\text { Duties. }\end{array}$ & $\begin{array}{c}(e) \\
\text { Ratio } d \\
\frac{d}{a} \\
\text { Nearest } \\
\text { Simple } \\
\text { Frac- } \\
\text { tion. }\end{array}$ & $\begin{array}{l}(f) \\
\text { Per } \\
\text { cent. } \\
\frac{d}{a}\end{array}$ \\
\hline $\begin{array}{l}1896-7 \\
1897-8 . \\
1898-9 . \\
1899-00 . \\
1900-01 . \\
1901-02 . \\
1902-03 . \\
1903-04 \cdot \\
1904-05 \cdot \\
1905-06 . \\
1906-07 . \\
1907-08 . \\
1908-09 . \\
1909-10 . \\
1910-11 . \\
1911-12 .\end{array}$ & 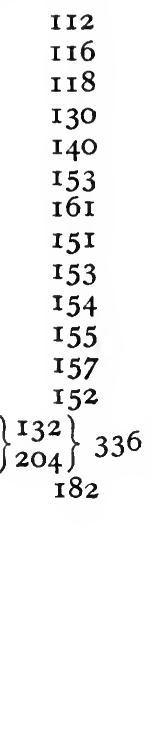 & $\begin{array}{c}16 \frac{1}{2} \\
17 \frac{1}{4} \\
18 \\
18 \frac{3}{4} \\
27 \\
35 \\
39 \\
31 \\
31 \frac{1}{4} \\
31 \frac{1}{2} \\
31 \frac{1}{2} \\
32 \frac{1}{4} \\
34 \\
13 \frac{1}{4}\left\{77 \frac{1}{4}\right. \\
62\} 74 \\
44 \frac{3}{4}\end{array}$ & $\frac{1}{4}$ & 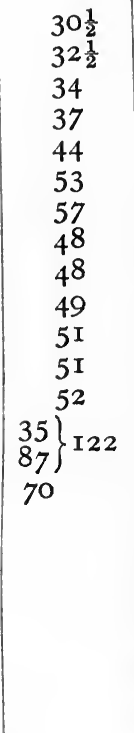 & $\begin{array}{l}\text { (Broadly } \\
\text { roughly } \\
\text { direct } \\
\text { have ir } \\
\text { from abo } \\
\text { of reve } \\
\text { about } \\
\text { little } \\
\text { dozen ye }\end{array}$ & $\begin{array}{l}39 \\
\text { and } \\
\text { put, } \\
\text { taxes } \\
\text { increased } \\
\text { out } 25 \% \\
\text { enue to } \\
39 \% \text { in } \\
\text { over a } \\
\text { evars) }\end{array}$ \\
\hline
\end{tabular}

One of the changes of outlook in economic matters that has come upon us, and that is still affecting us, is the relatively greater importance that we attach to the idea of income. Men's minds are turning to income as a more significant and important thing than property. The newer schools of thought express themselves largely in terms of income, and property is viewed more in relation to the income that it secures than has been the case in any earlier period. This change of thought is connected with the settlement of ideas concerning the nature of taxation, and both have expressed themselves in the changes that have taken place in actual tax-systems. The "Property and Income Tax " is generally spoken of simply as "The Income Tax," according to the preponderating and significant item. 
We should be able to get a very useful commentary upon the changes that have taken place in the distribution of taxation, if we could work out the amount of pure taxes paid at different periods by some representative payerssay a labourer, a mechanic, a farmer, a schoolmaster, a doctor, a banker, a large landowner, a millionaire, a multimillionaire, with a definite income posited for each. So much guesswork would be needed, however, that the result would be of little value. ${ }^{1}$ The proportion of direct and indirect taxation offers us a safer view of the change in the distribution of taxes, which may be put beside that relating to the Income Tax, for in main outline it indicates the transference of a larger proportion of the total taxes to deductions from income as such, and a like transference from the smaller to the larger incomes. The figures cannot be quite exact, but the movement, which is the thing we wish to notice, is large enough not to be affected even by a considerable percentage of error. Estimates of the relative proportions of direct and indirect taxation vary very greatly, chiefly according to what taxes are considered as " direct." An excellent example is given in Noble's " National Finance" (I875). In the session of I87I, the Chancellor of the Exchequer was asked what were the proportions of direct and indirect taxes at the time. His answer (summarised in percentages below) was challenged by Mr. Disraeli; who gave figures of his own, in which he included local taxes and the surplus revenue from the Post Office among direct taxes. Mr. Noble rejects the addition of the Post Office revenue (quite rightly) and separates out "Tolls, Duties, etc.," from local rates directly paid, adding the former to indirect Imperial taxes, and the latter to direct Imperial taxes. The three sets of figures for I87x, expressed roundly as percentages, come out thus-

Percentages.

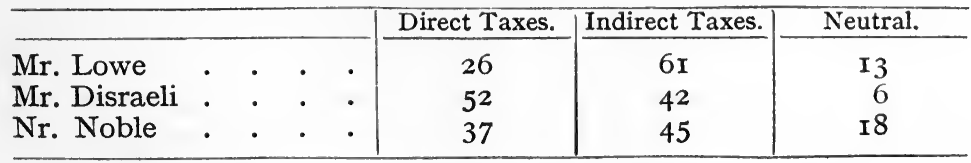


In the table that follows, the third column is not used, being merged into the body of direct taxes, where it more properly belongs. But the case just cited shows that figures of this kind are useless except to indicate very broad changes. It was at this period that Chancellors of the Exchequer began to express their anxious desire to " hold the balance even " between direct and indirect taxes, as if some economic law of equilibrium were implied. The phrase continues to recur in Budget debates, so that it may not be quite unnecessary to state that no such law of proportions is known to economists. It is purely a political product. Rates levied on business premises and on farms are, of course, " indirectly" levied, in any ordinary sense of the word. The tenant pays them, but if he were excused payment, his rent would increase proportionately. The classification of taxes as Direct or Indirect is discussed in Professor Bastable's "Public Finance," Bk. III. chap. iv., and in Book III. chap. i. There is a further discussion in Professor Bullock's " Direct and Indirect Taxes in Economic Literature," in the Political Science Quarterly, XIII. (cited by Professor Bastable, "Public Finance," III. i.).

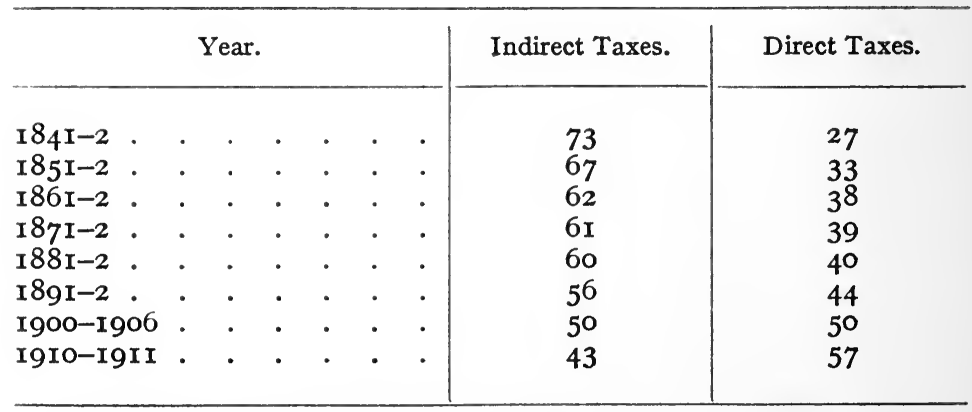

[Different figures will appear according to the definition of " direct" or "indirect" assumed. So long as the same method is used throughout (as above), the idea of change is truly given, even if each separate figure is inaccurate.]

By the beginning of this century, we had steadily moved to a practical equality as between direct and indirect taxation. 
This change is on the whole equivalent to a steeper graduation of the income-tax. It has other elements, but that is its most important economic effect. Taxes have been taken from articles largely purchased by the working classes, and their equivalents have not appeared to any considerable extent in the form of other taxes which the same classes are likely to pay. Such a change, in so far as it tends to take in taxes the less useful instead of the more useful portions of private incomes, is in harmony with the general principle of economy.

There are two other important changes implied by the lessening of the share of indirect taxation in the national receipts - the change in the class of goods from which most of the indirect taxes are raised, as expressed in the abandonment of protective duties, and the change which is making so as to concentrate the bulk of the amount upon commodities that are comparatively unnecessary for productive efficiency-alcoholic liquors and tobacco. Each of these changes, on the whole, is in its net results in agreement with the principle of economy, though in both cases something could be said in regard to certain of the gross results to show that the principle of economy is not observed.

If we would gather from what has happened and is happening, some indication of the direction of movement in taxation, we must examine the course of two currents-that of economic and political theory, and that of the practice of ruling bodies. Some of the evidence necessary for the former inquiry is here before us ; for the latter we must examine the budgets of the nations, and note their changes from decade to decade.

In economic and political theory we have already marked some lines of change, some indications of direction. These we may now conveniently gather up and set out.

First. An understanding of the real nature of a tax: a preliminary quite essential in building up any sound principle of taxation. That understanding is now secured, though it is only in times of men yet living that it has been made clear.

Secondly, the abandonment of theories found to be false 
or useless. Some of these, as that taxes are payments proportioned to the service given-the service of protectionwere in part based on inaccurate conceptions of the nature of a tax.

Thirdly, the greater prominence given to the claims and the duties of the community, and the less prominence given to the counter-claims of the individual. This finds expression in the decay of the notion that taxation is a necessary evil, to be kept at a minimum ; and in the growth of ideas such as that of minimum sacrifice.

Fourthly, the influence of changes in general economic theory: the growing importance of the idea of income as against the idea of property or capital ; the effects of the application of the laws of utility, especially of the law of diminishing utility as applied to incomes; the relations, hardly yet examined, between the distribution of wealth and the production of wealth: questions long examined in isolation from each other. These changes have caused, among other things, the shifting of the support of economists from proportional to progressive scales of taxation.

And in political practice we have in England, which will serve us as well as another country, these things to note.

First. The steady growth of public expenditure, accompanying the growth of public activity.

Secondly. The gradual abandonment of taxes that check production in any form, of taxes on necessities, on commodities generally, on transit, on goods imported.

Thirdly. The decrease in indirect taxation (following from the point last mentioned) and the increase in direct taxation, particularly to be noted in the case of the Income Tax.

Fourthly. The substitution of progressive for proportional scales in direct taxes-the Income Tax and Death Duties.

There is enough here of parallelism between theory and practice to be significant, enough to suggest like causes. Economists and governments have turned their attention more and more, as years have passed by, to the idea of income; and this change is important enough to demand some consideration.

We are not justified in assuming that the change is final, 
or that it is wholly or chiefly a change for the better. It is a change that is still in the making, and it finds expression in places where it is set out in other forms. There are, for example, two schools of democracy in this country that are essentially separated by this question of the primary importance of income or of property. Such democrats as are to be grouped with Mr. G. K. Chesterton or Mr. Hilaire Belloc would achieve the freedom and independence of poor people by, giving them a security of possession in property; whilst Socialist democrats hope to establish a like state of things through a more equal distribution of income.

- The idea of expressing wealth as income is much newer than the idea of expressing it in property. In the earlier stages of society, wealth would almost exclusively mean the direct and immediate possession of tangible property. To-day, a man may have little property that is his in any immediate personal sense, and yet draw a very large income from his earnings, or from securities he holds. Income is becoming more significant in the practice of life, in economic theory, and in political affairs ; chiefly, in this last case, in relation to national finance.

When economists were led by their inquiries into economic goods, to consider " services," there were two paths open to them. Had they followed the one path, and confined their studies to economic goods alone, they would not have found the phenomena of income of such magnitude as now appears. They chose the other path, and by including services in their circle of inquiry, were led to give more attention to the questions that gather round income.

We are becoming of opinion that property is only of economic significance in so far as it produces income: that income is to property as an end to a means. We say that Smith is "worth" so many hundreds or thousands a year. Even if we say he is worth $€ \mathrm{I} 0,000$, one of our first impulses is to figure out his income at four per cent.

By a parallel movement, taxation is viewed more in relation to income than to property. Income taxes, and taxes on incomes under other names, in spite of the general 
opposition that is offered to their establishment, show an unmistakable tendency to make a larger part of the total sums raised in taxes. Property taxes, as such, ${ }^{1}$ show rather an opposite tendency. One strong impulse has been the steady spread of an understanding of the economic truism that taxes are paid by persons, and not by land, or houses, or imports. When this is brought alongside the question, "How should taxes be distributed among persons?" it soon appears that some people with little property are able to pay quite large sums in taxes, because of their having large incomes. Further, it appears that taxes, however levied, are in fact paid out of incomes in the immense majority of cases. They are rarely paid by the surrender of property.

It is within the bounds of possibility that we may revert, in economics and in politics, to ideas of property rather than to ideas of income; or that we may adjust the proportionate significance of each in the direction of thinking and acting more in terms of property than in terms of income. But the signs are rather in the other direction. "Income is a promising idea," as a modern economist put it. Chancellors of the Exchequer sympathize with his view.

There is, then, a sound arguable case to be made out in favour of the view that taxes will continue to be and to become of the nature of direct levies upon incomes. There is undoubtedly a future for indirect taxes upon income, but there seems to be a prospect of a still longer life for direct taxes. The basis of men's preference for indirect taxes is largely psychological. Men dislike paying taxes, and they dislike all reminders of unpleasant things. If a smoker pays $£$ I per annum through the indirect tax upon tobacco, he can at least forget the unpleasant fact nine times out of every ten payments. And he has another comfort, also psychological in its nature, in paying an indirect tax. He pays in pennies, and not in pounds; and he will pay thirty shillings in daily pennies more cheerfully

1 Property taxes, however, remain or are extended whcrever property forms a more convenient basis than income-death duties, increment duties, local rates on fixed property, for example. 
than $£ I$ Ios. upon a given date in the year, whether at the beginning or the end of the year.

But large masses of men do, though slowly, come to take the exacter and less emotional views that are at first confined to a few philosophically-minded people. It is not certain that drapers will for ever be able to rely on " 4 s. $I I \frac{3}{4} d$." visualising itself in the minds of most of the customers rather as "four shillings and something " than as "about five shillings." Nor is it certain that an economist will always be able to say anything so sweeping as the following-even in the United States-" Revenue duties on imports are among the most convenient and popular forms of taxation, partly because the taxpayer does not realise how heavy the taxes are, and partly because of the common belief that such taxes are borne by the foreigners who export the goods." (Professor A. S. Johnson, "Introduction to Economics," quoted previously. In the original, the whole passage, and not the portions here noted, stands in italics as a heading.) The number, and the proportionate number of citizens in a state who believe that "the foreigner " can be induced or made to pay any considerable part of his taxes, or who thinks that only a very small part of the price of an ounce of tobacco represents a tax, is not a fixed number, or a fixed proportion, either in place or in time.

Nor is it desirable that citizens should continue to be ignorant in these matters. If citizenship has in it, as most of us undoubtedly believe it has, some desirable possibilities in developing the human race, then for a government to abet, encourage, or build upon the ignorance of its citizens in such a matter is as evil and vicious as for a despotism to abet, encourage or build upon the general ignorance of the masses of its subjects. It is not a good thing, but an evil thing, that people should be paying shillings in taxation whilst having a befogged idea that they are paying pennies. Let them know that they are paying shillings, and their interest in the manner of spending the shillings will be aroused. This may not always be to the taste of some politicians; but it will be of advantage to the body politic. Nor is it a good thing that the cheerfulness with which a 
citizen pays a shilling for a ninepenny article should be based on a belief that the foreigner pays twopence towards it, whilst the said foreigner is in fact paying a farthing, or nothing at all. A government of a free people should not seek to hide from the taxpayers what they pay, nor what they pay it for. It is true that very often both the government and the taxpayers find life made pleasanter by an indolent avoidance of the places where unpleasant things lie; and though the general idea that taxes must be paid may not be definitely unpleasant in itself, yet the actual paying of a tax is to be classed among things that men find unpleasant.

Nor is the method by which a man pays his taxes with the least possible consciousness of the reality and amount of the tax, any more soundly based economically than politically. A man of business is none the better for any ignorance of the amounts or proportions of his various payments. Production is not increased, nor is the distribution of wealth made any more justly, or in any sense more economically, by people thinking that five per cent. of their incomes goes in taxes, when in truth it is ten per cent. The ignorance of the taxpayers is not a justification of indirect taxes, but an explanation of their general acceptance.

It would follow, then, that the readiness of a people to pay directly as much as they are prepared to pay indirectly (or in part indirectly) is a quantity that varies in time and place with the extent of the knowledge and appreciation of the citizens in matters political and economic. Changes of methods and systems in taxation that are likely to make plainer to the payers what in fact they are paying, are only to be made by steps, and by steps varying in magnitude according to the stage of advance in political and economic knowledge of the people concerned. But changes in the contrary direction, deliberately designed to foster the ignorance of the payers, is not susceptible of any justification but that of opportunism or expediency. This is not to say that it may not be expedient or wise for a government, at a given time and place, to gather the bulk of its taxes by 
methods that take full advantage of the apathy or ignorance, political or economic, of its citizens. But it is to say that a government is behaving ill that acquiesces in that ignorance, or worse, that of set purpose takes no steps to lessen it.

We should keep in mind, in all our considerations and conclusions about income as a basis of taxation, that although income may be supported as the best basis of any yet tried, or suggested (a position quite open to attack), it is quite certainly not a perfect basis. A very short consideration of the following cases will show that income, in itself, does not measure taxable capacity from all points of view.

A, B, C, D, etc., are people whose incomes are equal in amount.

$A$ is a bachelor, drawing $£ 500$ a year from investments in Consols.

$\mathrm{B}$ is a doctor, married, with no children, earning $£ 500$ a year from fees.

$\mathrm{C}$ is his unmarried colleague, drawing an equal amount from a similar source.

$\mathrm{D}$, another doctor, has a wife and four children. $\mathrm{He}$ earns, in fees, $£ 400$, and his wife has an annuity of $£$ roo.

$\mathrm{E}$ is a shopkeeper who pays income tax on $£ 500$ a year. His actual income fluctuates, sometimes with violence.

$\mathrm{F}$ is a novelist and an "outside " contributor. Last year he sold the MS. of a novel outright for $£$ Ioo. This year and part of next he will be busy on another book, which he hopes to sell for more. Its success (measured in the money it will bring him) is uncertain. He will keep himself going for this year on occasional articles. Altogether last year he made $£ 500$; this year it will probably be $£ 300$. Next, year it might (with luck) be $£ 700$.

$\mathrm{G}$ and $\mathrm{H}$ duplicate the cases of $\mathrm{E}$ and $\mathrm{F}$, on the whole, except that $\mathrm{E}$ and $\mathrm{F}$ are unmarried, and support only themselves, while G supports a mother, a wife, and two children, and $\mathrm{H}$ a family of six.

$\mathrm{K}$ 's salary is known, and he pays income tax in full. His neighbour L, who always seems to be able to afford 
more than $\mathrm{K}$, has an uncertain income, and usually pays less in taxes than does $\mathrm{K}$.

We need here only mention and mark the difficulty. It is not insuperable, and a little investigation and analysis would suffice to sweep away some of the " $\mathrm{A}$ to $\mathrm{K}$ " anomalies, or to bring out effective compensating proposals. Something of this kind has in fact been done in practical legislation. But the difficulties implied are to be kept in mind.

\section{VII.}

Reviewing now the general bearings of the case as we are presenting it, we state it in something like a definite sequence.

The immediate or the final aim of the statesman may be to get in his taxes with the least friction possible; but that will not ensure, in itself, that the method adopted will do the least possible harm to the nation.

If a certain amount of taxes must be levied, then, so far as that consideration is concerned, he must see to it that the amount is forthcoming, by good methods or by worse. In that sense, we may, if we like, describe his first principle as the principle of Productivity.

But this does not carry him, or us, very far. If, while he is successfully "producing" his taxes, the nation is becoming economically impoverished, we shall look in vain to the principle of Productivity for further guidance.

If the statesman is chiefly concerned with the satisfaction of wants of all kinds, the wants that give rise to the existence of taxes being among them, then the effects of different taxes, in their bearings upon the production and distribution of economic goods, will be his first concern.

This consideration will lead him to take in taxes what can best be spared; as much as is needed (or declared needed through what organs of expression remain to the community), and no more ; all that is needed, and no less. Here he will be guided by the principle of economy.

If he be an autocrat, benevolent or otherwise, he may regard one principle only-economy, or productivity, or 
justice (by whatever code he may prefer) or any other. So we may conceive a perfectly wise benevolent autocrat deciding upon the principle of economy, bare and unqualified, adopting what we have called a "Procrustean" scale, and facing, as best he might, the whirlwind that would ensue.

Such an autocrat, again, more eager to give his people what they will immediately accept than to give them what they most need, and timid of whirlwinds, may regulate his taxes according to the code of justice as conceived in the time and place where he finds himself. He will meet with a minimum of disaffection (if we leave bare quantities out of the account for the moment), but the only guarantee against economic injury that will stand in his system, will be the instinctive adjustment that human institutions constantly make between their moral and other codes; things violently unjust, by their code, will not as a rule be things wisely economical, and vice versa. This view throws the principle of justice against its proper background. It is a safe, practical, inexáct, slowly-changing, conservative principle, in harmony with most things human, unscientific, comfortable, easily understood, and as acceptable to the mass of men as other unscientific, comfortable, and quite human things, from beer and tobacco to popular literature and popular theology. It is "the spirit of the age" expressed in terms of taxing.

We fall easily into the way of speaking of taxes (like other governmental acts), as things imposed upon a nation from without, rather than as things resolved on, and acted on, by a community for itself. We change to the latter conception upon sudden remembrance of the theory of democratic government, but we tend constantly to fall back into the view of "things imposed." Our attitude reflects the facts of life and of government. We have not yet built up a social machinery for actual self-government: we have no working model ; and it is this fact that makes the significance of the idea of gradualness in change. For where a community, with effective power over its own affairs, is convinced that a certain step is advisable-as towards, 
or actually to, a certain scheme of taxation, there is less need to divide the step into two, or ten, or any number of different steps, than when an imposing body has to consider the possible resentments of the bearers of impositions. Modern democratically-governed states stand between the two positions. In a sense, they impose their own taxes. In a sense, the taxes are imposed on them. The picture of the members of a community conferring to discover the best known plan of taxation, and taking immediate steps to put it into practice, does not fit in the frame of actual communities in being. In a confused and untidy way, the thing does take place; but the first process of discovery is never complete and decisive, much less unanimous, at the time when steps begin to be taken for the second process, that of working out the findings into practice. There are always sincere challenges of the findings, always the objections (sincere in another sense) of those whose interests seem threatened. Most troublesome of all, these two are confused, the more so as it is to the interest of the latter class of objectors to assume the protective colouring of the former.

Thus whenever we come to consider the definite act of translating any principle of taxation into terms of actuality, we need to have before us the community as it exists in fact, with its knowledge and ignorance, its beliefs, its customs, its code of conduct, its deeper and its shallower ruts and grooves of daily thought and action, its machinery of social life, its conscious past, its conscious and sub-conscious present. With this material, not only legislators and politicians must work, but effective economists also. We see the community imposing taxes, and the individual suffering them, or, as the individual taxpayer often puts it, suffering from them. 


\section{CHAPTER IV.}

The Limitations of the Principle of Economy.

I:

WE have now considered the content of the term Economy, as standing for a principle of taxation, and we have referred also to its implications. There are still to be considered its limitations-those limitations which prevent its being a sole principle; and further, the complementary principles or modifications which the existence of these limitations makes necessary.

From the point of view of the economist pure and simple, we may upon good grounds declare for Economy as a sole principle of taxation, classing other rules or maxims, not as principles at all, but as political expediencies, governed and controlled by the ethical prejudices and convictions, by the administrative convenience, and by the vested or immanent interests of varous groups of taxpayers. The arrangement might be much in this fashion.

I. Principle of Taxation-Economy; securing that the least useful monies are collected; that the productiveness of the community is hurt as little as the amount collected permits ; that the distribution of wealth, if altered, is not so altered as to lessen productiveness; that the same thing is secured as regards the distribution of population; that the cost of collection is small ; that what remains when this cost is taken from the total of the amounts paid directly and indirectly by the taxpayers is approximately equal to the amount received by the State.

2. Expediencies; or Political Rules of Taxation.

(a) Such as are advisable in order that no section of the community shall be so weighted as to enlist the 
sympathies of other sections; or, though less urgently, in order that no section shall be very strongly convinced of unfair treatment, for any considerable period, even if other sections are unsympathetic. For if government is to be by general consent, it must secure as nearly as may be, a general content.

(b) Such as are advisable in order that what Professor Cannan has called "legitimate expectations" may be respected ("Memoranda," p. 165). This is a particular aspect of $(a)$.

(c) Such as are needed to secure the smooth working of the machinery of taxation-a convenient method of collection, suited to the payers in regard to time, place, and manner of payment, avoidance of irritation, freedom from incentives or opportunities of evasion, steadiness and regularity, correct balancing between the amount actually levied and the amount required.

Economy, as a principle of taxation, is represented above as securing those effects most economically desirable in connection with six points; briefly-

I. The least useful monies.

2. The effect upon productiveness.

3. The effect upon distribution of wealth.

4. The effect upon distribution of population.

5. The cost of collection.

6. The total cost to the payers.

A consideration of these six points naturally suggests a method of grouping them. It is plain, for example, that there is overlapping, since the last four, at least, may fairly be considered under the general heading of the second. More closely related to our inquiry is a rearrangement from the point of view of the several interests of the community, the State, and the individual. This at once brings out the fact that all except the fifth, and more particularly all the first four, are framed as if with one chief objective, the well- 
being of the community, without regard to the interests of individuals as such. The fifth deals with the establishment charges and working expenses of a State Department, and represents the principle of economy as applied by the State to its own machinery. The last is applied as to the individual payers, but it is often of greater importance to the indirect than to the direct payers; and the indirect payers may form the bulk of the community. Thus in the case of import duties cited by M. Gide ${ }^{1}$ the excess of the total cost to the consumers over the total receipts by the Treasury is of far greater moment to the consumers of wheat (the community generally) than to the importers who directly pay the tax. Lastly, we may note that the first of the six points brings up a sharp antithesis, setting the interests of the community and the individual in two distinct categories, and quite possibly sacrificing the latter to the former.

There emerges now a possible classification on these lines-

\section{The Principle of Economy in Taxation.}

$A$. The State, considering chiefly or solely the interests of the community, will distribute and levy taxes (the raising of certain sums being already decided upon),

(I) in such ways as will check the production of economic goods as little as possible, or not at all ;

and more particularly,

(2) in such ways as will not help to cause any changes in the distribution of wealth as will in turn check the production of economic goods;

(3) or, in such ways as will not have any similar effect upon the distribution of population.

(This covers points 2,3 , and 4 of the six points first cited.)

$B$. The State, definitely setting the interests of the community above the interests of individuals, will distribute and levy taxes 
(I) so that the less useful parts of incomes will be taken before the more useful parts;

and also

(2) so that the ultimate or real payers will each pay only, as a consequence of the tax, the equivalent of their shares in the total receipts of the Exchequer.

(The first of these is point I of the group as set out above, and the second corresponds to point 6.) As for this last, it appears to represent the State as safeguarding the interests of individuals, rather than as setting other interests - those of the community-over them. In fact, it represents the State as setting the interests of the larger group (generally the consumers, who will sometimes include the greater part of the community) above the interests of a smaller group, as the producers in a particular industry.

$C$. The State in its function as the administrative organ of the community in the matter of taxation will so levy and collect taxes,

that the establishment charges and working expenses of the administrative machinery may be kept at the lowest figure compatible with efficiency.

We get a view, then, of the State pursuing Economy in the matter of taxes along three parallel paths, of which one (the third here mentioned) is relatively a minor path; the three being, in further summary-

$A$. Regard for the powers of production of the community.

$B$. Regard for the general interest where that may be opposed by individual interests.

$C$. Regard for the working costs of the machinery it sets up.

Further, as to what we have called Expediencies, or Political Rules of Taxation. The first (a, p. 213) covers a due regard for opinion; the second $(b, \mathrm{p}$. 2I4) regard for vested interests and expectancies; the third (c, p. 2I4 consideration for the smaller human passions, and arrangements for inducing the natural emotional man to act as 
the conventional rational man that civilization would make of him-a taxpayer, or a tax-collector, in this aspect of him. All three groups of expediencies, in fact, are related to man as an emotional being, for that is a much closer description of him than the eighteenth century term, "a rational animal." $\mathrm{He}$ is indeed rational, but still more is he emotional, and the administration that pays no heed to his emotions is likely to be swept away (perhaps violently) by their expression. The first expediency is broadly the expression of what is meant by "Liberalism" on the Continent, the second represents the steadying force of conservatism, and the third, the organizing and administrative work of officialism or bureaucracy. The first and second both express what has been classed under the terms Justice, Equity, and the narrower terms that have been used to define Justice or Equity more exactly-Proportionality, Generality, Graduation, and so forth. They differ in that the first is directed more towards personal claims, and the second towards what are called the claims of property, a phrasing which often confuses thought, for property cannot have claims or rights: such things can only properly be posited of the animate world. The distinction is between the rights or claims made by or for persons in virtue of their existence as persons and citizens, and those made by or for persons in virtue of their standing as legally-accredited holders of property. In practice, the distinction is very sharply drawn. An example, apt to the matter in hand, will illustrate how sharply.

The passage containing the phrase "legitimate expectations" runs in this manner. "The fourth generalization is one in which all except revolutionary socialists agree. It is that it is inequitable to disappoint legitimate expectations. Of course, the difficulty here is to say what are legitimate expectations, and it is quite hopeless to expect any two persons to agree absolutely as to where legitimate expectations end and illegitimate expectations begin" ("Memoranda," pp. I65-I66). Nevertheless, whenever there has been a question touching the compensation to be allowed for interference with definite vested interests, such as pro- 
perty rights, it has been discussed on the basis of "How Much ?" But where the claims are less material and definite, the doctrine of " legitimate interests" may not even appear. When the Elementary Education Act of 1870 was passed, a large number of parents were set a new task, a relatively severe task-that of paying directly part of the costs of education of their children. Parents with children whom they hoped would shortly be earning enough to ease the strain of providing the family expenses, a hope which could hardly at the time be described as an illegitimate expectation, since it was sanctioned by custom and had for centuries been legal, were baulked of their legitimate expectations, and no question of compensation in any form was debated. Yet the toll was relatively large; it was in cases from a fiftieth to a twentieth of the family income. A corresponding new demand, made of citizens in respect of their interests in property, would have been met by a very warm discussion. But, being made from parents as parents, and not from property-owners as such, so far from "all except revolutionary socialists" raising the banner of legitimate expectations, there was no discussion of that aspect at all, or none worth mentioning. And a like case occurs at each raising of the school leaving age. It will occur when the half-time system is abolished.

Of course, in final reference, all these things come to the question of the clash of public and private interests, and if private interests are more alert in defence and self-assertion in some cases than in others, they will receive proportionate attention. The whole subject of taxation is to be thrashed out as a conflict of private and public interests. The public case, generally speaking, is expressed through the principle of Economy as we have defined it, and the adjustments made to avoid causing a feeling of inequity as between individuals and classes, and to secure a smooth running of the machinery, are more expressly related to consideration for private interests.

This offsetting of the principle of Economy with the public aspect of taxation, and the remaining maxims or expediencies with the private aspects, is not offered as an exact 
classification. It will be found, however, that it covers most of the ground. The chief duty of the State, in the matter of taxing, is to have regard for the interests of the whole community, and its method is by the principle of economy. It must regard also the beliefs and prejudices of the citizens, and here it finds that certain methods of collecting are desirable, and others undesirable; that certain taxes are less acceptable to the payers than are others, which may yet in their economic effects amount to the same thing; that a certain scale of graduation is at a given time accepted as a rough approximation to justice, whilst a more steeply graduated scale would be furiously opposed by certain classes, and a less steeply graduated scale would call forth an outcry from other classes. In this matter the general conservatism of men shows itself very clearly. People have a tendency to accept what they have been accustomed to as the proper thing, as well as the normal thing. The economists of a hundred years ago thought the population of England was just about right - a few hundred thousand too many, perhaps, but roughly speaking, about sufficient. The population has increased greatly since then, and most of us are inclined to accept the present numbers as what they ought to be.

It is so with taxes. The Chancellor who makes no change stirs up no feeling against himself. "An old tax is no tax" is a phrase that aptly describes this tendency. The present English scales of Death Duties and Income Tax would have been almost universally denounced as monstrous, if they had been suggested a century ago. If they were now moved back to Proportionalism, a cry of injustice would arise from the Labour benches; if towards a steeper scale, that cry would come from another quarter.

The tendency is equally marked among writers on social and economic questions. Stanley Jevons wrote in 1869 ; "I venture to affirm that the available information sufficiently proves that no great inequality of taxation exists," and similar or stronger statements may be found in a large number of economists of repute for at least a century back. Yet since 1869 the proportions of direct and indirect taxa- 
tion have almost exactly been reversed, and new features of such importance as the graduated Death Duties, the differentiation between earned and unearned incomes, and the super-tax have been added to our system. Either there was considerable inequality then, or there is now-or ideas of equality have changed.

\section{II.}

We shall be able to form some idea of what things are left uncovered by the principle of Economy if we recall the various principles and maxims that, as we have seen, have at one time or another been put forward.

First, we have, as included more or less in the principle of Economy-

I. Exemption of Minimum.

2. Graduation.

3. Minimum Sacrifice.

4. Certainty (see below).

This is not quite satisfactory, since each of the first three may be as well discussed under the heading "Justice" as under "Economy." But we have discussed them here from the point of view of economy, which is as reasonable a method as any other, and according to our argument the case for them is that they are desirable ideals just in so far as they secure the taking of less useful instead of more useful parts of incomes for national purposes.

Next, corresponding with our first expediency (a), we have-

Equity (Justice, Generality, Ability).

And corresponding with our second expediency $(b)-$

I. Convenience.

2. Consistency.

3. Elasticity, and perhaps-

4. Certainty.

"Certainty" is rather difficult to place. Uncertainty as to the amount, or even as to the time of payment, would 
tend to act as a check upon production. On the whole, Certainty might be classed under Economy.

Next we have some principles which are no longer strongly held by administrators or by economists, to any extent-

I. Diffusion.

2. Unity.

3. Proportionality.

"Relation to Franchise" is a purely political question, now only important in most modern countries as far as it concerns women taxpayers. It could be discussed under "Justice" or under the administrative expedients of the third group.

"Productivity" would go, if anywhere, in the third group ; but it does not readily lend itself to our classification.

What emerges is that when we have had regard for the principle of Economy, we must have regard for the emotions of men. We come back, after recalling and arranging the " principles," " maxims," " canons," " rules " of taxation, to the view already expressed. Taxes affect production. Then let production be checked as little as possible. Taxes are not paid by economic men, but by human beings. Then outrage their feelings, rouse their prejudices, irritate them, as little as possible.

To the administrator, to the statesman, to the politician, the second of these things may often weigh more than the first, or at least be more insistent. But in so far as he sacrifices the first to the second he is acting by expediency, and not by principle; by political principles perhaps, but certainly not by economic principles.

In the practice of life these things are settled by the fact of quantitative thinking taking the place of qualitative thinking. The method, which has sometimes been adopted, of arranging the rules and principles of taxation in a sequence of importance, so that the less important rule shall give place to the more important, does not adequately describe what happens. The only sequence and relativity here advocated is that Economy shall stand first. Yet even that cannot be posited in bare qualitative fashion. We 
cannot say that a Chancellor will, or shall, or ought to put Economy before Justice. The question "How Much?" arises. Certainly a very economical tax should have precedence over one that a small class will think rather unjust. But what manner of statesmanship would that be, that put forth a scheme of taxes likely to secure a very little more economy at the cost of arousing a great and bitter feeling of injustice in the minds of most of the citizens? We do not speak of taxes that are in fact unjust, for as we have seen, there is no fixed criterion of justice, apart from legal, moral and customary codes. We must deal with the sense of injustice, as it is felt. As for the grounds of it, that is to be dealt with by discussion and argument, by the educative forces that work on the minds of men; and this must very largely precede the actual taxing. It might here be urged that in the case of the Igog Budget, the " education of public opinion " was undertaken by both parties after the scheme was introduced. That is true enough, but it is also true that in the main the people who were for or against the Budget in April were for or against it in December. It is true that men's ideas as to what constitutes a just distribution of taxation have changed, and are changing, but the process is a slow one.

Between sacrificing a little justice to gain much in economy and losing a little economy to avoid what will be thought a terrible injustice, there lie many gradations; and where these occur there must be a quantitative calculation of some sort before a decision is taken. "Economy should take precedence of all other considerations" is a sound rule, according to the ideas here set forth; but not irrespective of all quantities. It is only true so long as we speak qualitatively. It ceases to be true when the other considerations weigh heavily with men, or when the economies in question are so small as to weigh lightly. Further than this, we find it difficult to go. If we can imagine an equivalence of $x$ economy as against $x$ expressed in equity and convenience (rather a hopeless imagining) then indeed we may unhesitatingly put the claims of economy first; with this proviso, that except in times of great excitement, men do not readily: 
make very big changes of any kind, not even to secure rather large gains; or, in other words, the $x$ representing the proposed change must be small as compared with the whole of which it forms a part, i.e. the total revenue, or the totality of the tax-system. But when we would ask ourselves whether $x$ economy may rightly or safely be attempted at the cost of $2 x$, or $3 x$, or $4 x$, expressed in terms of injustice felt or irritation aroused, we can find no general answer. Oxygen is more vital to life than food; yet men live in air that is relatively poor in oxygen, in order to obtain food, and are not uniformly willing to go from Bethnal Green, where they earn their food, to Salisbury Plain, where the air is purer, but where food-for them-would be less easily earned.

Suppose now that the whole case were built up with the idea of fixing Justice rather than Economy as a first principle. Would it be possible to make as good a case, or perhaps a better case? We think not: but an outline of the attempt should be instructive.

To begin with, we are met by the difficulty of defining Justice. It cannot be the legal code, for each change in taxation makes a change in the legal code of which it is a part, and every important change might be checked through being inconsistent with the legal code of the moment. People who owned motor-cars were recently called upon to pay a new tax, which formed no part of the legal code at the time they bought their cars. They might then invoke the legal code as it stood, the moment before the new tax was laid on them, to prove the injustice of the tax. In fine, the legal code as a criterion of justice, with justice as a first principle of taxation, would go far to fix the system of taxation which happened to be in use at the time when this method was adopted.

Could we then take the moral code, or rather, a certain moral code? We must consider what it is. A moral code is either a divinely-given system of law, or the expression of socially-developed conventions into rules that have been defined and strengthened by custom. As for the former, it belongs to theology, and there we must in this connection 
leave it. The latter renders morals into manners, customs, conventions. These things have fluidity, and not fixity, change and not permanence. That, however, will not of itself obstruct us much. The prevailing code at any given time will suffice for the taxes proposed at that time.

But there will not be a general agreement as to whether a proposed tax is just or unjust, exactly because the standard of judgment is not fixed. This also is not insuperable. It will rarely happen that the community is equally divided, and as in other things the majority will have it.

Now if we secure what the majority count as just, what other of the requirements in the various principles or maxims we have reviewed are thereby also secured? Above all, what measure of economy is secured? Nothing of economy is necessarily secured. A people ignorant of economics, but passionate for justice as they view it, is equally likely to accept a progressive, or a proportional, or a degressive scale of taxation, according to the general circumstances of their lives, and to their beliefs and prejudices. They are as likely to be Free Traders as Protectionists, apart from all economic considerations; as likely to tax one thing only as to tax everything, to tax capital, or commodities, as to tax income. This is to speak of an imaginary nation; but it is also exactly true of any nation that puts the principle of justice first, up to the point when they begin to consider economic effects also. The principle of justice implies that people will be satisfied that their taxes are not unjust, but it implies no more.

The same thing is not true of the principle of economy. We can take another imaginary nation, that considered economy first, and follow it to the point where other considerations came in. Productivity would be encouraged, as compared with the first nation (we must suppose them otherwise alike), industry would thrive, wealth increase, at a faster rate. These things would not only mollify the sense of injustice (we are considering justice to have been ignored so far), but they would alter the ideas held about injustice. What was working for the general benefit, it would be said, could not be altogether unjust. It would not be long before 
the economist party would claim to be exponents of justice equally with their opponents.

We have seen also that inquiries directed towards a satisfactory description of justice have converged towards the point to which Economy more immediately leads. Equity is defined as Ability to Pay. That is measured by Proportionality in respect of income. Proportionality is modified by the Exemption of Minimum Incomes, which leads to Progression. Progression has no standard of measurement, and the doctrine of Minimum Sacrifice is applied to it, which will fix the scale in harmony with the law of diminishing utility : a law that the principle of economy applies at once.

What, further, of relatively minor rules, such as Convenience, Certainty, Consistency, Electricity? They are all of them more important on account of their relation to private and communal economy than in relation to ideas of justice. A taxpayer will certainly feel that he is the more justly treated in proportion as his convenience is suited in the taxing, as he can count safely on the relative fixity of the tax, and as the various taxes are not irritatingly inconsistent. But the chief value of such rules is nevertheless in their economic effects upon production. It is for such effects that he values them. The economic aspect is paramount.

We are not urging that if Economy is secured, it will carry with it all other good things. But we are urging, first, that Economy is the most important and most influential thing, and that it carries with it a larger proportion of other desirable elements than would any other rule. Further, we are claiming that a system of taxation should be built upon what is definite, fixed, and measurable, rather than on some other thing (which may be equally desirable otherwise) which is indefinite, unfixed, and immeasurable. Equity or Justice, as we have partly demonstrated, partakes of these latter characteristics rather than of the former; and the reverse is more true of Economy.

It will throw some further light upon the relative position of Economy in questions of taxation if we consider for a moment whether the other principles or rules that should be added to Economy are of the nature of correctives or of 
complements. For if they are correctives, they indicate to that extent the possibility of error in a system based on Economy alone. If they are complements, they indicate only that Economy does not cover the whole ground.

Just so far as a rigid application of the principle of Economy to an existing system would arouse a feeling of injustice, just so widely as that feeling extended, just so long as it was held, it must be maintained that correctives are called for. We have seen that by its very nature, Justice is a varying and changing thing, as applied in human governmental affairs, and by men's judgment of them ; and hence all changes for the sake of economy are likely to stir up some feeling of injustice. But so indeed do all changes in taxation for any sake-that is, all changes in the manner of levying. There must be some who under the new system are harder hit, or at least relatively harder hit, than under the old. The justification of the change is the public advantage; and that is almost entirely expressed in Economy.

Rules about Convenience, Certainty, Consistency, Elasticity we cited as being partly contained in the principle of Economy (the first three, at least, since their observance prevents friction in the business of producing things); partly complementary to it, in that they ease the working of the administrative machinery; and partly corrective, as helping to allay any feeling of irritation and injustice that might be aroused by any methods that considered Economy only. But the clash between Economy and other rules is not vital or inherent. No nation that has adopted a more economical system is very likely to return to a less economical one. We cannot say more than " not very likely," for the thing has happened. But the broad movement of the systems of civilised states is not in that direction. It is safe to say that the tax-systems of to-day are more economical than those of a century ago, and that those of a century hence are likelier to be more than to be less economical than those of to-day.

Further, as we have already suggested, an economical system changes the public view so as to produce its own justification. It justifies itself first in action, and as a result 
gains the gradual support, however grudgingly given at first, of those classes that once cried out at its injustice. Who now would advocate the repealing of the Income Tax and the Death Duties, and the restoration, in their place, of taxes upon commodities? Yet the Income Tax and the Death Duties were at first opposed on the ground of injustice. It is not a complete answer to give as an explanation the phrase "An old tax is no tax" 1 ; for if they were unjust, they are still unjust, unless the standard of justice has changed (as in fact it has), or unless the classes then unjustly hit have since seen the balance restored by some other re-distribution of taxes, relatively relieving them. As a matter of fact, that has not happened. Such " injustice" as was done has indeed been accentuated. But we have purchased at the cost of a temporary feeling of injustice on the part of a class, the common gain that comes of a more economical system.

What seems to emerge from our inquiry is that the necessary corrective or supplement to the principle of Economy in taxation is little more than the political expedient of caution in the extent and rapidity of change. A nation of economic men, or of rational beings, would no doubt accept the full and immediate application of the principle of Economy at any stage where it might be offered. But men are for the most part far more amenable to emotional than to rational impulses, more conservative than radical in the greater part of their activities, more inclined to bear those ills they have than to fly to others that they know not of. It is for the economist to discover what system of taxes is the most economical in action, and for the statesman to judge how best to change the existing system into that, by what steps, at what rate. When Economy, and the manner and rate of change have been decided, there is little else to be secured by any code of maxims. These two considerations will practically cover the whole field : they will modify the standard of justice as they are set in action, and while

1 The phrase meant that producers of goods were not disturbed by existing taxes. Its application to Income Tax or to Death Duties is rather irrelevant at best. 
modifying it, will satisfy it. More general injustice to the community might easily be dealt out, in the working of a system that aimed chiefly at justice, and that set economy aside, than by one that aimed at economy, and trusted largely that justice would thereby be secured.

We have no single term in which we may express this advisability of gradual changes in systems of taxation, to correspond with the way we have used "economy" to stand for the wider significance in which we have been using it. We may put it that as economy is the first principle, so gradualness is the first expediency of taxation; and that if both be translated widely, they meet the demands of the economist and of the statesman. The taxmaker should see to it that every change in the system of taxation should be towards greater economy, and that no change should be so violent as to arouse general opposition; the taxpayer, that his means of satisfying his wants-his powers of production and consumption-are lessened, if at all, only that the general powers of the community may be increased; that his personal feelings and prejudices, his personal convenience, are not refused the consideration due to a citizen.

\section{III.}

We arrive, in fine, at a principle that lies deeper than any principle of taxation, or of government, or of any single social phenomenon; one that lies, indeed, as the basic principle of them all-the public advantage. We have seen that Austin, in his search for the root-principle of justice, arrives at this, and expresses it as "general utility."1 Maeterlinck, studying the organisations of men through the medium of the organisations of bees, arrives at substantially the same principle. To this also come inquirers into human codes of morals (save that, where they are theologians, they express themselves appropriately). But we have no need of reliance upon authorities. Man is, or has become, a social animal, and the social fabrics he constructs become more and more complex. In the building of his 
fabrics he may follow no rules whatever, in which case no order, no coherence, no continuity will appear. But since, in reviewing the social fabrics erected by man, we do in fact find something of order, of coherence, of continuity, we infer that he does follow certain rules, though not always consciously, not always consistently, not always without divergence.

He may follow these rules, again, unconsciously or consciously. He may build by instinctive rules, as a bird its nest. Pass, for our purposes, that we are not quite clear as to the exact nature of what we call instinct in the bird, and let it stand that the rules that have guided men in the building of their social fabrics are conscious or unconscious. They are not all unconscious, now at least, or we should not be discussing the rules of taxation in this book. They are, then, either partly conscious and partly unconscious; or wholly conscious ; or they were at first unconscious and are becoming more conscious : which last will best run with the view already put forth in, this discussion, that man, an emotional being, is slowly being trained by the social machinery that he constructs into being less an emotional and more a rational being, all recrudescences and counteracting forces notwithstanding. This is not to suggest that human emotions are in process of elimination. They may remain in quantity the same-they may in quantity increase, without disturbing our argument. They change in quality, and, most significant of all in the present connexion, in the sphere of their application. The proportions of the parts played to-day by emotion and by reason in questions of religion, morals, marriage, kingship, government, democracy -in all social institutions, are not fixed proportions that have for ever subsisted. Yesterday they were different ; to-morrow they will be different.

Now in all these cases, in all things dealing with man in society, with nations and communities, one principle has dominated the social code of morals, of jurisprudence, of government: that when the clash comes between public and private interests, the public interest shall prevail. This is the fundamental law of all communities, human or 
other; and this, in final analysis, is the fundamental law of taxation also.

But we need a more immediate law that will bear more directly upon the single case of taxation, and give us a readier and more practicable guidance. Such a law should lie as close as possible to the fundamental law of public advantage, for the better security of its soundness, and as close as possible also to the definite subject of taxation, for the greater readiness of its application. Such a balanced principle, we submit, is to be found in the principle of economy rather than in any alternative principle that has been suggested.

What that principle needs in the way of limitation, expansion, translation into definite and particular acts of taxing, is outlined in the relation we have established above; a relation that may be pictured out in this manner :

$\begin{array}{ccc}\text { A } & \text { The } & \\ \begin{array}{c}\text { Definite } \\ \text { Scheme } \\ \text { of }\end{array} & \begin{array}{c}\text { Principle } \\ \text { of }\end{array} & \text { Public } \\ \text { Economy. } & \text { Advantage. }\end{array}$

This setting brings out these considerations-

(i) That any principle of taxation that may be offered us should stand or fall by the prime test of its sufficiency as an intermediary between schemes of taxation and the principle of public advantage;

(ii) That any directer intermediary, that is, one closer related to public advantage and to practical taxing, is to be preferred to one more indirect.

(iii) That as the intermediary is closer to public advantage it is the more soundly based, and as it is nearer to some practical scheme it is more immediately available;

(iv) That conversely, as the intermediary moves further from public advantage it becomes less surely based, whilst it may, by approaching more nearly a practical definite scheme, become more available. But we must not be led away by the mere neatness of the arrangement. In the terms of the pictured grouping we may say that the inter- 
mediary (the principle of taxation under examination) may get further from public utility by being moved up or down, and so getting further also from practicality. A principle of taxation is not the readier of application in the practice of life simply because it is far from satisfying the practical needs of the day.

A truer figure would be based upon a circle, whose area would represent public advantage, of which one sector would be the public advantage in relation to taxation. The true principle of taxation, whether Economy or some other, would then appear as the arc of that sector, limiting and defining the public advantage as expressed in taxation. Actual schemes of taxation would lie in this sector, within the circle, or in the continuation of the sector (see diagram next page).

The arc $A B$ would represent the principle of taxation, the arc AC might stand for the principle of democracy, and so forth. The figure, of course, is a figure only, not a basis for inferences. The point in immediate question is simply the relation between (I) tax-systems, (2) tax principles, and (3) the general welfare.

What room, then, does such a view allow for the play of political expediency? If, for instance, the economists of this or any country were to frame a scheme of taxation at once widely different from the scheme in actual use, and confessedly in accordance with the general welfare or public advantage-perhaps even perfectly so in accord-to what extent would its immediate acceptance be consonant or dissonant with the practical political wisdom of politicians and statesmen dealing with citizens; actual men dealing with actual men?

From another approach we have already come to an answer, to be summarised in "gradualness"; but this was not directly related to the idea of public advantage. How should we consider it in this aspect? For in the whole area of the circle representing the idea (or the fact) of public advantage, we have supposed to lie all matters affecting the advantage of the social fabric, whether political, moral, economic, or other. There should be an answer, then, 
directly derivable from this statement of social affairs.

The answer would be, that the social life of man in a nation is a unity made up of economic, political, and other

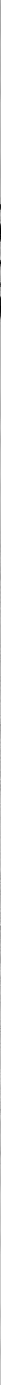

factors; that a change in one must affect some others; that a distinct economic gain to the community may result from certain changes, such as a sudden change to a better 
system of taxation, and yet so disturb men's moral poise in regard to ideas of justice, or so disturb their intellectual poise in regard to the efforts demanded in grasping, assimilating, and adjusting the new ideas, standards, relations, connected with change, that the net gain, in the way of general public advantage, may be little, or nothing. There may be a net loss. In its application to our immediate problem this marks out as the limit of the application of the principle of economy, the point where the definite economic gain to be obtained by a stricter application of economy is exactly neutralised, in terms of public utility, by an equivalent loss in the total public advantage, in terms of any human desirables whatever that may be included under the phrase "general public advantage." In terms of our figure of the circle, we might put it that if a system of taxation is improved, and represented by a wedge penetrating a circle, so that the fullest advantage is obtained when the apex of the wedge is at the centre of the circle, the gain of the movement towards the centre is lessened exactly in proportion to the disturbance caused by the "splitting" effect of the penetrating wedge. Or, still in terms of the figure, we may say that the various principles adopted (which are arcs of the circle) should be in alignment, so that the arcs join and form the continuous circumference of a complete circle. The conception of the movable sector or wedge more accurately fits our problem : but in both cases, of course, it is necessary to insist that the figure is only a figure.

Thus again we arrive at gradualness as the essential limiting concomitant of the principle of economy. "Make your taxes constantly more economic, and make your changes slowly" would be the practical rule resulting from our argument and inquiry.

\section{IV.}

If we flinch-as many may well do-from the conclusions to which our inquiry has led us, or from some of the more alarming aspects of these conclusions, we may with profit 
stand and consider the alternatives before us; like a prospector or explorer, whose course has led him to a difficult and windswept hill slope, counting up the paths still open to him, should he blench from the steep hill ahead.

First, there is the alternative of immediate return. For the traveller that may be simple, but for us, heirs and ancestors of socially-living men, it lacks the simplicity of a starting place to which we may return. It is ages since the journey was begun, and there have been many long halts and stops. The plain suggestion arises that we should return, if we are to return at all, to one of the latest stoppingplaces. What are these? The nearest point of a long halt is, in reference to our immediate hill of difficulty, the doctrine of Proportional Taxation. It offers the advantage of security, from the point of view of all holders of capital or of income above the average of any given time and place. It offers, further, a fixed mathematical scale of charges: A with $£ I, 000$ capital or income shall pay twice as much as $B$, with $£ 500$ capital or income, and not a penny less or more. It satisfies, moreover, the cruder, more elemental, and more widely spread of human conceptions of quantitative and apportioned justice in this matter. Whoever has not inquired into the thing (and that is to say, the bulk of men) will readily accept the idea that a tax of $£ 5$ taken from a total of $£ 500$ is equivalated by a tax of $£$ Io taken from a total of $£ \mathrm{I}, 000$. In figures and amounts it is, in very fact. In persons, as we have seen, it is not. But men were content with it for a long period.

There are two difficulties to be faced, however, if we would make such a return. There are paths made, outposts constructed, human settlements established, along the line of retreat, and these must be abandoned. For there are, first, such areas and provinces of economic theory as have been mapped and charted on the route-the theory of diminishing utilities as applied to individual incomes, the theory of marginal utilities as applied to spending, in the effort to get the same marginal utility in each item of expenditure. We cannot consistently abandon these theories in taxation and yet retain them for other branches of economics, without 
giving ourselves and others sufficient explanation for the differentiation. There are explanations to be given-the fear of affecting future saving, for example. They have often been stated, but they would now need more than statement. They would need to be established as adequate.

The other difficulty is that we have figured, in our simile of the explorer, as the establishment of human settlements. For in the financial systems of modern nations there are groups of taxes arranged deliberately according to nonproportional progressive scales. The mere existence of these makes a formidable barrier in the line of retreat.

An alternative course, which might or might not be reckoned as another line of retreat (here we view it in that light) is in an abandonment of direct taxes, and a deliberate effort at obtaining all or most of our taxes by indirect imposts-by customs, excise, protective, or similar duties. A political school and party might quite conceivably arise, with the avowed object of bringing about such a change, a " New Tariff Reform Party," or " Commodity-Tax Party." It would not be altogether new, for among the writers cited in Chapter II there are some stalwart advocates of Consumption-Taxes. There is nothing impossible in the idea of the advent of such a cry as "Revenue by Tariffs Only," or " Tax Things, not Men." War cries of no greater intelligence have gathered thousands round their symbols, and will again. However, be it likely or unlikely, it stands as a distinct alternative. There may be classed with it such similar plans (similar, that is, in relation to our immediate point) as a Single Tax, whether on Land Values, on Rents (with or without Quasi-Rents), or on Profits. We have already stated a case for the belief that if there is to be one tax only, it should be assessed on incomes.

One alternative remains. We may avoid the difficulty by avoiding taxation. It is not taxes, as such, that States need, but revenue. Is there any sufficient source, apart from taxation, by which a State might conceivably secure a sufficient revenue ? There is certainly one, and perhaps one only-State property. When we gather into one view the present position of the states and municipalities of the world, 
in relation to State railways, municipal trading, nationalisation schemes and practices, revenue-yielding public works of all kinds, and set them in their place in the tables of public finance, we find a definite and interesting inquiry suggested. What are the relative changes in proportions, in the increasing amounts of public revenues, between taxation on the one hand, and revenue from public property on the other? The total revenue, the income from taxes, the income from State and municipal property, are all increasing. But of the total revenue it is probable-we may say certain, that the amounts contributed from these two sources will continue to change in relative bulk. It is possible that one may dwindle, and the other grow. It may be that States and municipalities will abandon all or most of the profitmaking enterprises in which they are at present concerned, and aim at obtaining the bulk of their revenues from taxes alone. It may be that they will embark on fresh schemes of State and municipal trading, and, if successful in obtaining profit-revenue, gradually abandon methods of taxation. If we survey the Budget changes of this country, for the last thirty years, let us say, we shall certainly infer that the movement is towards more taxes, rather than towards more profits. The growth of municipal trading in this country, the State-owned railways, canals, forests, of other lands, however, point the other way. We are yet so close to the parting of the ways-considering the civilised world as a whole-that it is still open to debate whether the human race is travelling along one or the other path. This, however, seems certain, that the Budgets of a century hence are likely to show, as a main and overshadowing item, one great source of revenue, and that will be either Taxes or Profits. The other of these two great items may actually have disappeared altogether. The selection of the item is one of the results that will follow when the whole question of what is now called Socialism is no longer a question about which men can debate with any fierceness. The question of taxation, however, must not be conceived as a derivative question, awaiting the final answer to some other simple definite question. There are degrees and quantities in 
Socialism and in the composition of budgets. States will go on, and will collect revenues; there will be changes and counter-changes; the cataclysm is not an inherent and essential method of human development.

Speculation about the future, however, is but speculation. Let us return to our more immediate point. This last alternative of an adoption of (or return to) the method of securing a revenue from State property entails the purchase of property by the State, unless methods of confiscation are used. How is the purchase-money, meanwhile, to be raised? Plainly, by loans, by taxes, or by the existing plan, which includes taxes as a very considerable item. The loans will bear interest, so that here also, as in the other cases, we find a scheme of taxes implied, for a period of transition, even in the case of a nation definitely arranging to raise its income from State property. This last alternative, therefore, is not a clear and immediate alternative.

We find ourselves limited then to a choice between Proportional Taxation, or a large scheme of Indirect Taxes, if we would avoid the difficulties that the application of the principle of Economy brings in our way, with a final alternative of Revenue from Public Property and Public Trading, after a transition period during which the method of raising taxes, by some plan or other, must be used. If we are to revert to Proportionalism, or to Indirect Taxation, we must abandon the principle of Economy as a chief and dominant rule. If we adopt that principle, we must lay a heavy hand on big incomes. Whatever may be our individual desires as to the path that the nations should choose, whatever may be the path that they rightly ought to follow, whatever is the path they are in fact already treading, it is well that we should put all the alternatives clearly before us, and know the goal towards which we move, the reasoning by which that goal was chosen, the instruments and calculations of the surveys that located its bearings and position. Though indeed we do live "hand to mouth," as individuals and as nations, yet we may exercise some control over mouth and hand and food also. 


\section{V.}

The economist has in fact no principle of taxation whatever to offer to the statesman, the politician, or the citizen, but the principle of Economy. What other principles he may add to this are either special aspects of it, or are borrowed from politics, from ethics, from what yet has been created of the science of history. The very limitations of the principle of Economy that he might mark out, as economist, would only be fuller expositions of the same principle ; as when he would say. "If, in collecting taxes from the least useful parts of income, you check men's impulse to save (that is, to increase the stock of wealth-producing agents), then your scheme will have a bad as well as a good economic effect. The net economy will stand as the true test. If the total economic loss outweighs the total economic gain, then the very principle of Economy that you quote must be cited against you."

The economist is one among a group of inquirers into different parts and aspects of social life. We see, in the perspective of history, the human race coming to live more and more in a fashion that implies and creates a mass of connecting threads between each individual life and the lives of other human beings. Social life itself grows more complex, and its growth brings about a correlative growth of social machinery-laws, states, systems of property-holding ; local, national, and international organisations, associations, societies, and so forth. Side by side with these growths again, arise studies of them-jurisprudence, ethics, economics. Man makes certain gains by association with other men, and suffers certain losses. Now he is alarmed at his loss of freedom, and speculates on " natural life," or Individualism, or Anarchism, philosophic or other. Again he is alarmed at his loss in being unable to work co-operatively with men of other crafts, other nations, other religions ; and considers theories of Cosmopolitanism or The World State. The social fabric that he builds is not a thing whose laws of being and growth he knows by instinct ; and as it grows, he must seek for its laws. 
Viewed thus, we seem to see Taxation and the principles of Taxation as an ephemeral thing. There were not always taxes : there may be an end to taxes. Here is a thing that has come into the social fabric that men have built and are building - not extraneously, but as part of the fabric itself. We may stop to examine it, to consider its nature and the laws of its being, either by itself, or as part of a part of the fabric, or as part of the whole fabric.

So, when we consider Taxation in itself and its more intimate relations, we find one principle, Economy, sufficient to satisfy all our immediate demands. It is when we consider the whole human organism - a nation, a race, or the total of humanity, that we find the principle of Economy insufficient in itself. But none the less, when we are considering the directer and more immediate effects of one thing that affects man in society, such a thing as Taxation, it is the fundamental principle of that one thing that is first and more immediately to be considered. The collateral principles are for the collateral effects.

We turn first, then, to those inquirers into the laws of our social fabric, who are more immediately concerned with the thing in hand, for guidance as to the chief direct principle of taxation; and their answer, as far as the inquiry made here reveals it, seems to be concentrating into this one answer, Economy. Next, and after we have satisfied ourself on the immediate point, we turn to other inquirers, to ask what reactions will result, in politics and ethics, from a more conscious and persistent application of such a principle. But their advice cannot have to do with the substitution of any alternative principle. If the principle is wrong, it is because the economist has done his work badly. It must go back to his hands, and he must labour and search again. In any case, he and no other must do the work. From the very nature of his work, the things that lie within his sphere must best be done by him. If he cannot do them, no one can.

His errors-and they are notorious-are of two kinds. The first are errors springing from his ignorance of his own task, the second, from absorption in his own and ignorance of 
other spheres of inquiry. For the first, we can but reject the results of his craftsmanship, when he brings them for our acceptance, and send him back to make anew, and make better. For the second, we must consider, not whether the window he has made will let in the light-we send him back with it until it does-but whether it will fit into the general building.

In fine then, the limitations of the principle of economy in taxation are the boundary lines between the domain of economics and the domains of politics and ethics; and it is only because the chief effects of taxation are economic that its fundamental principle is one of economics. If we consider taxation chiefly as a thing of ethics or of politics, then indeed our chief principle should be equity or convenience, or some precept of the moralist or the politician. But up to the present, we have looked to the economist for our principles of taxation.

Are we then to conclude that if we have taxation at all, there is nothing open to us but this continuous movement (whether slow or quick, steady or spasmodic), towards some such drastic scale as that we have called Procrustean Taxation? By no means. We can have, at each decade of our history, and will have, whatever form or type of taxationsystem we can effectively demand; which is, whatever form the mass of the community, acting within the limited effectiveness of the political machinery of the time, most strongly desires. But if we would know what is the true and essential nature of taxation, and what its essential and fundamental principle, we turn, naturally enough, to the economist. We may question him, purely as economist, or as a citizen who, inter alia, has studied economics. In the latter capacity he will give us as many picturesque and varied answers as his fellow-citizens who are doctors or engineers, except that he will include in his statement certain things common to all inquirers in his branch, and known to them, which may or may not be in the statements of other citizens. That is to say, the variety of opinions among individual economists concerning political and ethical principles of taxation will be as great as the like 


\section{LIMITATIONS OF' PRINCIPLE OF ECONOMY. 24I}

varieties among individual engineers; and there will also be some differences, though in less degree, upon aspects more strictly economic.

But as economist simply, he will of necessity fly back to his basis, which concerns material well-being, the satisfaction of wants, the production, distribution and consumption of economic goods. He will consider the effects of taxation upon the sum-total of satisfactions of wants-economic wants-and will seek how taxes may be levied so as to leave those satisfactions undiminished; or if not that, then as little diminished as possible. On such a course, he must inevitably come to a principle indistinguishable from what we have called the Principle of Economy, though he may not express it under that name. Then indeed he may add to his findings what he will in the name of politics and ethics, setting forth the whole view of the social life of man, expressing his ideas of the relative importance of national security, Imperialism, political stability; of justice, civil and moral law, immediate or more remote expediency. These additions of his may easily be of much greater significance, in the complete human view, than his finding as economist ; but that is no ground for their confusion with it. But it is rather our business than his, as citizens of a social state, to make these additions; to take the results of his inquiry, rather, and consider their value, their place, their dominance or subordination, in the whole scheme of social life. We are building round the human race, century after century, a vast artificial environment, and taxation is one of the incidentals of that environment. Our task is to find its nature, its function, its effects, its best use. To grow angry with our discoveries were childish; to be dissatisfied with them is human and hopeful ; to be over-eager to accept or reject them is to be prejudiced. We are all builders of a social fabric, and some of us, in a sense; are architects. Builders or architects, we need most of all, and constantly, a sense of proportion. 


\section{SUMMARY.}

THERE is now an agreement, sufficiently general for acceptance, as to the essential nature of a tax.

A tax is distinguished from other payments, and in particular from a price, in that-

(a) it is compulsory,

(b) it is not given for a definite measured something in return.

Taxes may be purely taxes, or may be mixed with other payments, which in themselves are really prices. Thus we get a short series, with Pure Taxes at one end, Prices at the other, and mixtures of the two (Quasi-Taxes) between these extremes.

Any principle of taxation that may be laid down should only refer in strict completeness to Pure Taxes. Its application to Quasi-Taxes is more properly to the element of Pure Tax which they contain.

A historical review of definitions of taxation reveals a movement towards a common definition. No satisfactory solution emerges, however, from a like review of statements on the principles of taxation.

The characteristic principle of taxation should be closely related to its essential nature, and should possibly derive from it. Since there is approximate agreement as to the nature of taxation, we have a basis upon which to build.

Since the nature of a tax is only expressible in the form of a dualism $((a)$ and $(b)$ above), the principle of taxation may be, in like manner, two-fold in form. We may have to deal, not with one fundamental principle, but with twin principles.

If there are two such principles, one of them may be of more importance when price-elements enter into the tax, and as the tax itself becomes less pure in form; and the 
same principle may become of less importance as the tax becomes purely a tax. Such a principle would probably be more closely related to prices than to pure taxes.

The other principle may be important in its relation to pure taxes, but of less importance or relevance with regard to prices.

The principles that have been put forward are mainly these-Equity (translated in many ways), Economy, Certainty, Productivity, Uniformity, Generality.

Of these there are two that are put forward with great frequency: Equity and Economy. We may therefore test them in the way just indicated.

Assuming now that two principles of taxation remain, or have emerged as Equity and Economy, of approximately equal bearing upon Quasi-Taxes, there is a preliminary presumption that one of them is more strictly a principle of Pure Taxes, and the other a principle more directly related to prices. For we have two elements, Taxes and Prices, that meet and mingle in Quasi-Taxes ; and the two principles may be a corresponding pair, and may similarly meet.

Now for the prices they pay for things, men desire chiefly an adequate return: they ask for a just exchange, an equitable bargain. For the Pure Taxes they pay, there is no standard by which they can measure the return. Here they ask chiefly that the community should take only what the community needs, and no more, directly or indirectly; that of two things, as two pieces of gold, equally useful to the community, but of different values to the owners, that one should in general be taken whose loss will be the less felt.

Again, where taxes are not pure in form, but approach to prices (e.g. water-rates) the principle of equity becomes of more importance, and the principle of economy of less importance. For where the return is in some sort measurable, and is by some standard actually measured, economy becomes the more assured by the fact that equity is observed, since no bargain will be accepted as a just one where economy has been ignored. But with pure taxes, there may be justice between individuals without economy being assured, as where a million pounds is levied so that no one feels himself 
more hardly dealt with than another, while half a million, levied in the same way, would have sufficed for the purpose or where the method of collection is needlessly costly.

If Equity has more relevance to Prices than has Economy ; and if Economy has more relevance to Pure Taxes than has Equity, then the fundamental principle of Taxation is Economy rather than Equity.

The politician, concerned chiefly with the reactions of human nature, and dealing in great part with human emotions, will naturally be obsessed by the need of satisfying the ideas of Equity possessed by the nation with which he is concerned. The economist, concerned with the production and distribution of economic goods, will as naturally be obsessed with the idea of economy.

The principle of Economy would lead us to a graduated rather than to a proportional scale; to direct rather than to indirect taxes ; to taxes on income, and on things that directly imply income; to the avoidance of tax-burdens upon necessities, or upon processes of production or means of transport. And correlatively, the broad changes in systems of taxation that are taking place, are actually in these directions. Meanwhile, changes in ideas about equity have come, justifying on the grounds of equity those alterations that at first were attacked as inequitable, and were chiefly defensible on the score of economy. Thus our findings are in harmony with general world-movements, and receive some empirical support in this way.

The fundamental principle of taxation is Economy; the ethical principle is Equity; the political expediencies are Convenience, Certainty, and all the concomitants of smooth working. All these, save economy, may be classed as political.

The wider principle of Public Advantage is best expressed, in relation to taxation, in the terms of the principle of Economy.

The chief limitation to the application of the principle of Economy to any system of taxation may be expressed as Gradualness. Masses of men never accept quickly those changes, however good, that are thrust suddenly upon them. 
The principle of Economy demands (I) that taxes should be levied so that the production of economic goods may be checked as little as possible, or not at all; (2) that if the distribution of wealth is altered, the alteration will be such as to increase productivity ; (3) that the like will apply to the distribution of population; (4) that the less useful parts of incomes will be taken before the more useful parts; (5) that the whole of the loss to the taxpayer will reappear as a gain to the Treasury, or as nearly so as possible; (6) that the cost of collecting will be as low as is compatible with efficiency. These are the six salient branches of the principle of economy : six tests to apply to any new or existing tax.

The economist may dwell upon this fundamental principle of taxation, but the citizen, the statesman, the politician must consider how men must deal with men. Equity is not a small thing, but large; Convenience and Certainty are not negligible to a taxpayer, nor is Productivity to a Chancellor of the Exchequer. Yet there are some of these things more fundamental than others; and of these the first is Economy. 


\section{Appendix to Chapter I.}

\section{A COLLECTION OF DEFINITIONS.}

The definitions here following will show whatever of development has taken place in the settling of ideas. about the essential nature of taxation. Such a collection has its own curious interest, and it has a certain usefulness for purposes of reference. But it is not for such interest for such uses, that it has been made, or that it is now presented. The part it is intended to play in this work is to bring to light the views that have been held, that have been abandoned, that have emerged, or that have persisted ; to enable us, from this fragment of history, to observe a fragment of the science of history; to observe, not only how thought has moved, but whither it is moving. For such a purpose the order must be chronological. The definitions given were at first arranged in one chronological sequence; but the effect was too confusing to be satisfactory. "Tax," "Impôt" "Steuer" are not identical terms, and there is a gain in clearness and accuracy in presenting each of them in its own chronological sequence.

The plan adopted is this-

$\S$ I. A list of tax-terms, English, French, German, and a few Italian.

$\S 2$. "Tax" and "Taxation."

First, "Dictionary definitions " from Dr. (Sir James) Murray, Webster, and the "Encyclopædic Dictionary" ; with a definition of "Task" for comparison.

Secondly. A chronological series of definitions extending from I65I to IgIr.

$\S$ 3. "Fee," "Revenue," and "Rate" ; chiefly "Dictionary definitions."

$\S$ 4. "Impôt." The range covered is from $\mathrm{I} 756$ to I906.

§ 5. "Stewer." I744 to I908.

$\S 6$. A few other terms, with a note on incorrect definitions (this from Leroy-Beaulieu, whose own definition, given under " Impôt," is not correct, according to the modern English and German view). 


\section{Note on the Definitions Given.}

What emerges from an examination of this material is chiefly the correspondence of meaning in the most modern definitions of "Tax" and "Steuer." This cannot be said of the term "Impôt" to anything like the same extent. The "modern definition " of a tax is expressed by nearly all the latest economists, with the variants such as are to be expected (and desired) in human affairs. In its simplest form it finds expression in Professor Cannan's "That portion of State revenue which is exacted irrespective of services rendered to the payers by the State "; in Professor Taussig's " absence of a quid pro quo" and " necessarily a compulsory levy" ; in Dr. van der Borght's " what is compulsorily taken from private incomes, without any definite services being rendered in return." There is a common feature here, essential to the modern idea of a tax, which scarcely appears in the definitions of "impôt," - i.e. what is expressed in these three definitions by " irrespective of services rendered," " absence of a quid pro quo," " without any definite services being rendered in return." But this feature, according to the view taken in the present book, is inherent in the very nature of a tax. It is what prevents a tax from being a price.

\section{$\S$ I. A LIST OF TERMS.}

List of Terms used to Represent TaXes and what are OR HAVE BEEN CONSIDERED AS Similar to TAXES.

English.

Aid, appraisement, assessment.

Benevolence.

Cess, custom, charge, contribution.

Due, duty.

Excise, exactment.

Gavel, gabel.

Help, hilp.

Impost.

Levy.

Poll.

Rate, ransom.

Sess, salvage, subsidy.

Tariff, tax, tallage, talliage, toll, tithe, tenth, tribute.

Valuation.

\section{German.}

Abgabe, Auflage, Anlage, Accis.

Bede, Beisteuer, Beitrag.

Gebühr, Geld. 
Hülfe.

Impost.

Licent.

Recht,

Steuer, Schatzung, Schoss.

Tadel, Taxe,

Ungeld.

Zoll.

\section{Italian.}

Censura, Gabella, Imposizione, Tassa, Tributo.

French.

Aide.

Contribution, capitation, cotisation.

Dîme, droit, denier, douane, dixième.

Gabelle.

Impôt, imposition.

Levée.

Octroi.

Péage.

Redevance.

Subside.

Taille, taxe, tribut.

Vingtième.

See also under De Parieu's definition of "Impôt," p. 262, and the lists on p. 265.

\section{§ 2. TAX, TAXATION.}

\section{Dictionary Definitions.}

Tax.

A contribution imposed by authority upon people to meet the expenses of government or other public services.- "Encyclopædic Dictionary"' (I879-I888).

Tax, taxe; Fr. taxe; Low Lat. taxa, a rating, a taxation; Lat. taxo, to handle, to rate, to value ; taxo $=$ tacto, from tactus, p.p. of tango, to touch. Tax and task are doublets. $S p$. tasa, Port. taxa ; It. tassa.

\section{Ibid.}

Tax.

A compulsory contribution to the support of government, levied on persons, income, commodities, transactions, etc., now at fixed rates, mostly proportional to the amount on which the contribution is levied.-Dr. (Sir James) Murray's " New English Dictionary" (I888 et seq.). 


\section{Taxation.}

Fixing the sum of an impost; assessment; imposition or levying of taxes.

Ibid.

\section{To Tax.}

To censure; to charge ; to make a valuation of ; to assess : to impose.

The word " tax" can be traced back at least to the year I405. It is earlier than the French " taxe."

Ibid.

\section{Tax.}

(M.E. taxe, F. taxe, fr. taxer, to tax, L. taxare, to touch sharply, to feel, handle, to censure, value, estimate, fr. tangere, tactum, to touch. Cf. Task, Taste.)

I. A charge, esp. a pecuniary burden imposed by authority; specif., a charge or burden, usually pecuniary, laid upon persons or property for public purposes; a forced contribution of wealth to meet the public needs of a government.

2. A sum imposed or levied upon the members of a society to defray its expenses.

3. A disagreeable or burdensome duty or charge; as, a heavy tax on time, health, and strength.

4. Charge, reproach, censure.

5. A lesson to be learned; a task.

Syn. Impost, tribute, contribution, duty, toll, rate, assessment, demand, exaction, custom.-Webster's " New International Dictionary" (I909).

Task.

Lit. " a tax," O. Fr. tasque-Low L. tasca, taxa-L. taxo, to rate, tax.- "Chambers' Etymological Dictionary" (I885 edition).

O. Fr. tasque, tasche (Fr. tâche) from Low Lat. tasca=a tax, from Lat. taxo=to rate, value, tax.- " Encyclopœdic Dictionary" (I879-1888).

\section{A Chronological List.}

For the impositions that are laid on the people by the sovereign power are nothing else but the wages, due to them that hold the public sword, to defend private men in the exercise of their several trades and callings.-Thomas Hobbes, "Leviathan," II. 30. (I65I).

Customs and tributes are nothing else but their reward who watch in arms for us.-Thomas Hobbes, "Philosophical Elements of a true Citizen," "Of Dominion," XII. 9 (I65I). 
Those levies therefore which are made upon men's estates, by the sovereign authority, are no more but the price of that peace and defence which the sovereignty maintaineth for them.Thomas Hobbes, "De Corpore Politico," II. 5. 2 (I655).

Tax.

A mere tax is but pulling of plum-trees, the roots whereof are in other men's grounds.-Harington, "Oceana." The Second Part of the Preliminaries (I65I).

Tax.

"____ the subject; who, when properly taxed, contributes only, as was before observed, some part of his property, in order to enjoy the rest." - Sir William Blackstone, " Commentaries on the Laws of England," Vol. I. VIII. xvi. (I765).

Tax.

I understand therefore by tax, in its most general acceptation, a certain contribution of fruits, service, or money, imposed upon the individuals of a state, by the act or consent of the legislature, in order to defray the expenses of government.-Sir James Steuart, "An Inquiry into the Principles of Political Economy," V. I (I767).

Taxes.

Taxes are sacrifices made of wealth and opulence at the expense of enjoyment, to security, in respect of defence, and in respect of subsistence.-Jeremy Bentham, " A Manual of Political Economy," chap. ii. (I798 and later).

contributions to be collected from individuals ; in a word, by taxes. The produce then of these taxes is to be looked upon as a kind of benefit which it is necessary the governing part of the community should receive for the use of the whole.Jeremy Bentham, " Principles of Morals and Legislation," XII. xvii. (I789).

\section{Taxes.}

Taxes are a portion of the produce of the land and labour of a country, placed at the disposal of the government; and are always ultimately paid, either from the capital, or from the revenue of the country.-D. Ricardo, "Principles of Political Economy and Taxation," VIII. (I8I7).

Tax.

A tax is a portion, or the value of a portion of the property or labour of individuals taken from them by Government and placed at its disposal.-McCulloch, "Taxation," p. I (I845). 


\section{Taxation.}

Let us proceed then to consider the method by which Government ought to raise the contributions required for such public expenditure as cannot reasonably or conveniently be provided for by charging individuals in proportion to services rendered; where there is no public income adequate to such needs derived from land or other wealth owned by the community or from the profits of governmental business. It will be convenient to call this the method of " taxation" in the strictest sense--H. Sidgwick, “Principles of Political Economy," III. viii. 559 (I883).

\section{Taxes.}

Taxes are simply one-sided transfers of economic goods or services, demanded of the citizens, and occasionally of those who are not citizens, but who nevertheless are within reach of the taxing power, by the constituted authorities of the land for meeting the expenses of government or for some other purpose, with the intention that a common burden shall be maintained by common contributions or sacrifices.-Prof. Ely, "Taxation in American States and Cities," chap. i. pp. 6-7 (I888).

\section{Taxes.}

' Taxes are not an exchange, nor are they a payment. The sovereign power demands contributions from citizens regardless of the value of any services which it may perform for the citizen. This is a clear abandonment of the old legal fiction that taxes are paid for protection.-Professor R. T. Ely. Ibid. p. 7 (I888).

\section{Taxation. $\mid$}

Taxation means work, of the head, of the hand, or of the machine, or all combined. And the method of taxation is only a method of distributing the products of work. It is measured, when in the process of distribution, in terms of money, but the money itself stands for work, or is derived from work. And the work of the Government is as much a part of the work of the community as any other. All who work, from the head of the nation down to the lowest municipal official, must be supplied with shelter, food, and clothing ; and those who pay the taxes do the work that is necessary to furnish this supply.-Edward Atkinson, "The Industrial Progress of the Nation" (N.Y. I89o). "Taxation and Work," same author.

[This definition is quoted with approval by Dr. D. A. Wells, in the Popular Science Monthly, Sept,, I896, p. 581.]

Tax. 1

The word "tax," as I shall use it, applies to any series of 
contributions authoritatively required of individuals according to some published principle of assessment.-E. A. Ross, "A New Canon of Taxation," Political Science Quarterly, Vol. VII. No. 4 (I8g2).

\section{Taxation : Tax.}

The most general feature of taxation, that marks it off plainly from other payments (in money, kind, or services) is, that the payment is compulsory. A tax is an exaction levied by superior force; it is not the result of charity, persuasion, request, or contract, although these names and sometimes the ideas which they stand for have been used to disguise or modify the original compulsion." - Prof. J. S. Nicholson, "Principles of Political Economy," V. vi. § I (I893).

Tax.

It is that certain portion of the product of a country which must be devoted to the support of the Government.-Dr. D. A. Wells, "Principles of Taxation," Popular Science Monthly, Sept., I896.

Scientifically considered, taxation is the taking or appropriating such portion of the product or property of a country or community as is necessary for the support of its government, by methods that are not in the nature of extortions, punishments, or confiscations.-Ibid. (I896).

Tax : Revenue.

The ordinary sources of revenue of modern governments divide themselves into three groups: (I) Prices, (2) Fees and Assessments, (3) Taxes.

A price is a charge for special services which people are not compelled to accept unless they choose. A fee or assessment is a charge for special services which people are compelled to accept whether they will or no. A tax is not based on special services, but is a forced contribution to the general expenses of the government.-Prof. A. T. Hadley, " Economics," XIV. § 494 (I896).

\section{Taxation : Taxes.}

Taxation is a system of forced contribution to meet the general expenses of the government, whether national or local. Taxes are distinguished from fees and assessments in being a contribution for general services instead of a more or less inadequate return for special services.-A. T. Hadley, " Economics," p. 449 (I8g6).

\section{Taxation.}

Taxation is the exaction from the various members of the 
State of contributions towards the common expenditure.Professor Gonner, "Memoranda on Classification and Incidence of Taxation," C. 9528, p. I44 (I899).

\section{Taxes.}

Taxes are contributions towards the general expenditure, Imperial or local, of the State, exacted by it from its members in respect of something they possess, or something they do.Ibid. p. I49 (1899).

\section{Taxation.}

Equality of benefit is one thing; rental value is another thing. They may equate, but they do not necessarily do so. It is indeed the antagonism between equality of benefit, and the basis by which this equality is measured which produces taxation. Because taxation pure and simple only occurs where the charge falls: (I) in no relationship to the benefit conferred; (2) where it is in excess of the benefit conferred.-(Sir) G.L. Gomme. Ibid. p. 237 (I899).

\section{Tax.}

A tax or rate is an obligatory contribution by persons in respect of, or incidental to, something which they possess or something which they do.-Sir E.W. Hamilton. Ibid. p. 33 (I899).

\section{Taxes.}

-Taxes in the proper sense of the word, viz., contributions by individual members of the community to the expenses of the State.-Sir Robert Giffen. Ibid. p. 93 (I899).

\section{Taxation.}

The most general feature of tax, that marks it off plainly from other payments (in money, kind, or services), is that the payment is compulsory. A tax is an exaction levied by superior force ;

It is to be observed that in a sense every tax that is levied for the public good may be regarded as providing in its expenditure a quid pro quo. ... It seems best, however, in the modern State, to apply the term tax to payments which are made primarily for the public service, and in which the benefit to the individual is not primarily considered.-Professor J. S. Nicholson, "Principles of Political Economy," III. v. vi. (Igor).

Tax.

A tax is a compulsory contribution of the wealth of a person or body of persons for the service of the public powers.-Prof. Bastable, "Public Finance," III. i. § 3 (3rd Edition, I903). 


\section{Taxation.}

In the matter of other governmental services, such as those of the police, general defence and the like, no measure of the amount of service rendered to each can be applied, and thus no price in the ordinary sense can be fixed for these services. The distribution of such charges has to be determined. In other words, not merely are land, labour, capital, etc., claimants for a distributive share in the annual available output of wealth in the community, but the government is also a claimant, in respect of the expense of rendering services which are not paid for in prices charged for the services or products yielded. This share of the government is claimed and yielded in the form of taxation.-Professor Flux, "Economic Principles" (I904).

\section{Taxation.}

Taxation may be defined as the taking by the government of private property for public uses.-Professor Fetter, "The Principles of Economics," chap. 49, § I. I (I907).

Tax.

Tax is a term wide enough to include all payments imposed by the government of a state on the persons and property within its jurisdiction.- “ Chambers' Encyclopœdia” (New Edition, I908).

\section{Taxation.}

To regard taxation as a process by which society acting through the state takes income which it has earned by social work, and which it needs for social life, is not an entirely novel conception though widely divergent from the commonly accepted view.J. A. Hobson, "The Industrial System" (Ig09).

\section{Tax. Fee. Rate.}

In this sense (i.e. the narrower sense, as appears from the context) taxes are general compulsory contributions of wealth levied upon persons, natural or corporate, to defray the expenses incurred in conferring a common benefit upon the residents of the State. A tax is justified, but not necessarily measured, by the common benefit conferred.-Prof. Carl C. Plehn, "Introduction to Public Finance," II. i. 5 (Igog Edition).

We may now change our terminology slightly, and say that there are three sources of public revenues : the first is collected from all the citizens by compulsion, on the ground that certain expenditures are necessary and confer a common benefit upon all ; these are taxes. The second is collected by compulsion from certain persons on the ground that they are specially benefited by some expenditures; these are fees. And lastly, the State 
creates wealth for itself. The wealth thus created constitutes a part of the revenue of the government belonging to the third class. This, whether sold or not, is contractual revenue or commercial revenue, and is received in the form of rates.Ibid. II. i. § 6 (Ig09).

Tax.

Confining our analysis to the accepted principles of American law, it is observed that a coerced payment from "the subject to the sovereign must meet three conditions in order to be recognised as a tax. These are as follows-

(I) This payment must, in the first place, be for some public purpose. ...

(2) A coerced payment from the State ${ }^{1}$ to the sovereign must, in the second place, be levied in a spirit of equity and justice as between the subjects in order to conform to the modern legal conception of a tax. . . . .

(3) The demand of a State for money in order to be rightly accounted a tax must, in the third place, be made according to established legal rules.

From the point of view of the State a tax is a source of derivative revenue.

From the point of view of the citizen a tax is a coerced payment.

From the point of view of administration a tax is a demand for money by the State in conformity to established legal rules.

From the point of view of theory a tax is a contribution from common expenditure."-H. C. Adams, "The Science of Finance," II. i. 49 (I909).

\section{Taxes.}

That portion of State revenue which is exacted irrespective of services rendered to the payers by the State.-Professor Cannan (I9I0).

(Revised.)

A tax is a contribution to State revenue which is exacted irrespective of services rendered to the individual payer by the State.-Professor Cannan (I9I3).

\section{Taxation.}

Taxation is the deflection of the resources of members of the taxed community from purposes which they would have selected for themselves to purposes which are selected for them by the

'Evidently a misprint for " subject." 
governing power.-P. H. Wicksteed, "The Common Sense of Political Economy" (IgIo).

Tax.

We may define a tax as a compulsory contribution made to Government, under stated conditions, when the contribution is not a quid pro quo for a specific service rendered.-Professor Chapman, "Outlines of Political Economy," chap. xxxiii. (I9II).

\section{Taxation.}

(From tax, derived, through the French, ${ }^{1}$ from Lat. " taxare," to appraise, which again is connected with the same root as tangere, to touch), that part of the revenue of a State which is obtained by compulsory dues and charges upon its subjects.Sir Robert Giffen, in the " Encyclopœdia Britannica," IIth Ed. (IgII).

\section{Tax.}

The essence of a tax, as distinguished from other charges by government, is the absence of a direct quid pro quo between the taxpayer and the public authority. It follows that a tax is necessarily a compulsory levy.-F. W. Taussig, " Principles of Economics," II. Bk. viii. chap. 66, § I (IgII).

\section{§ 3. FEE, REVENUE, RATE.}

Fee.

I. Live stock, cattle, whether large or small.

Wild fee : deer.

2. Movable property in general; goods, possessions, wealth.

3. Money.

4. Comb. Fee-house

(a) in O. E., a treasury.

(b) a cattle-shed.

I. Feudal Law. An estate in land (in England always a heritable estate), held on condition of homage and service to a superior lord, by whom it is granted and in whom the ownership remains ; a fief, feudal benefice.

2. Common Law. An estate of inheritance in land.

3. A territory held in fee : a lordship.

4. The heritable right to an office of profit, granted by a superior lord and held on condition of feudal homage.

1 This is doubtful. The New English Dictionary traces the English word "tax" to I405, which is earlier than the French "taxe." See also a footnote in Dowell's " History of Taxation and Taxes in England," Vol. I. p. xii. "Tax," short for " taxatio," from the Low Latin "taxare," is all the same as assessment. It occurs in the Statute Book first in 1327. . . . " desore (dès ore, dès l'heure) soient taxes solone lanciene manere." 
5. Homage rendered ... also, employment, service.

\section{Denoting a payment or gift.}

6. A tribute or offering to a superior.

7. The sum which a public officer (? originally, one who held his office " in fee ") is authorised to demand as payment for the execution of his official functions.

8. A perquisite allowed to an officer or servant.

9. A fixed salary or wage; the pay of a soldier. Also, pl. Wages.

I0. A prize, a reward.

"An occasional gift, a gratuity given in recognition of services rendered.-Dr. (Sir James) Murray, "New English Dictionary," (I888 et seq.).

Fee.

A. S. feoh, feó, cattle, property ; cognate with Dut. vee, cattle ; Icel. fé ; Dan. and Sw. fœ, fä ; Goth, faihu ; Ger. vieh; O. H. Ger. fihu; Lat. pecus; Sansc. paçu.

Ordinary Language. (I) cattle (obs.). (2) property, goods (obs.). (3) a reward, compensation or return for services rendered. (4) a share, a portion (obs.). (5) wages (Scotch). (6) possession.

To fee.

(I) To give a fee or reward to ; to pay; to reward.

(2) To keep in hire.

(3) To bribe, to hire.

(4) To let out to hire.-Webster's "New International Dictionary" (Ig09).

Customs and Subsidies.

Thus Customes are those artificiall duties that our kings must have, and Necessity hath layd on Trafficke by our Staple Cömerce, to supply theyr naturall defects, and wants of Bullion.

And Subsidies are those naturall respects which Loue is desirous and Loyaltie doth offer, by Traffick to honour our Soveraignes by (besides theyr auncient Customes) that by all Meanes, and at all hands Maiestie may be seen, and Soveraigntie subsist.-Thomas Milles, "The Customers Alphabet" (I608).

\section{Revenu.}

The national revenue (revenu) is the total of the superfluities of the citizens.-Forbonnais, "Principes économiques," IV. 6 $(I 767)$.

\section{Revenue.}

The revenue of the sovereign is in the last analysis only that 
part of goods (substances), and raw materials, annually produced, assigned to his personal enjoyments, and to those of his cooperators or representatives of all kinds.-L'abbé Baudeau, "Politique tirée de l'Ecriture sainte" (I775).

\section{Revenue.}

The revenue of the State is the portion of his possessions that each citizen gives to have the remainder in security, or to enjoy it in comfort.-Montesquieu, " L'Esprit des Lois," XIII. i. (I748).

\section{Revenu.}

The Physiocrats used the word "revenu" to signify rent of land exclusively, "this rent being in their eyes the only annual gain realized by society,"-Eugène Daire: "Collection des Economistes-Physiocrates, v. 2. p. 473 (I846).

\section{Revenue : Taxes.}

The revenue which must defray, not only the expense of defending the society and of supporting the dignity of the chief magistrate, but all the other necessary expenses of government, for which the constitution of the state has not provided any particular revenue, may be drawn, either, first, by some fund which peculiarly belongs to the sovereign or commonwealth, and which is independent of the revenue of the people; or, secondly, from the revenue of the people.-A. Smith, "Wealth of Nations," V. ii. (I776).

[This " secondly" is treated of, later, under "Of Taxes." (V. ii. Part ii.), which begins thus-

"The private revenue of individuals, it has been shown in the first book of this inquiry, arises ultimately from three different sources : rent, profit, wages. Every tax must finally be paid, from some one or other of these three different roots of revenue, or from all of them indifferently.']

\section{(To) Rate.}

I. To fix, assign, settle the amount of.

(b) to divide proportionally; to allot or apportion (between or to persons) as an amount or sum to be received or paid.

2. To reckon, calculate, estimate the amount or sum of.

5. In pass. To be subjected or liable to payment of a certain rate ; to be valued for purposes of assessment, taxation, or the like.-Dr. (Sir James) Murray's " New English Dictionary " ( 1888 et seq.).

\section{Rate.}

(O.F. rate, raite, ratte; med. $L$. rata, from $L$. pro rata, fem. of ratus, pp. of rēri, , to think, judge : cf. (see) Ratio). 
I. I. The (total) computed or estimated quantity, amount, or sum of anything, usually as forming a basis for calculating other quantities or sums.

(b) A fixed portion or quantity.

2. Estimated value or worth (of individual things or persons).

(b) Estimation, consideration.

(c) Valuation, rating.

3. Price, the sum paid or asked for a single thing.

II. 4. The amount or number of one thing which corresponds or has relation to a certain amount or number of some other thing.

6. (d) Amount of assessment on property for local purposes.

III. 9. Standard or measure in respect of quality or condition. -Dr. (Sir James) Murray's "New English Dictionary" (I888 et seq.).

\section{§ 4. IMPÔT. \\ A Chronological List.}

L'impôt.

Taxes properly ordered, that is to say, which have not degenerated into spoliation by a bad form of imposition, should be regarded as a part of revenue detached from the net produce of the landed property of an agricultural people.-F. Quesnay, "Maximes," V. note (I756).!

Impôt, and Contribution.

The contribution (contribution) of the citizen to the public treasury is a tribute, is an offering. It only belongs to him that gives it, that he may offer it.-Mirabeau (Victor de Riquetti), "Theorie de l'Impôt," IX. (I760).

A tax (impôt) then is not a contribution in its nature; it is the revenue from the co-ownership of all the productive land (fonds) of the state, a co-ownership which belongs to the sovereign power.-Mirabeau, "Supplément à la Théorie de la'Impôt," Résumé, II. (I776).

A tax is a property ; this property belongs to authority ; authority belongs to justice; justice belongs to God. Taxes are God's portion (la part de Dieu), that is the nature of taxes.-Ibid. III. (I776).

\section{L'impôt.}

Society must pay those expenses that are essential for preservation of society, for preserving order, and for maintaining the rights of property.

The portion of wealth which pays these public expenses, is called taxes $\left(l^{\prime} i m p o ̂ t\right)$.-Dupont de Nemours, " De l'origine et progrès d'une science nouvelle," §XIII. (I767). 


\section{Impôt.}

Taxes are a portion taken from the annual revenue (revenu) of the nation, to form an individual revenue of the sovereign, to enable him to sustain the annual charges of his sovereignty.Mercier de la Rivière, " L'Ordre Natur el des Sociétés Politiques," V. (I767),

\section{Impôt.}

The sacrifice of a part of one's property to secure the remainder. -Raynal, "Histoire philosophique et politique," XIX. xliii. (I77I).

\section{Impôt.}

A tax (impôt) is a part of wealth, annually reproduced, destined for the public expenses and taken from the net produce.- Le Trosne, "De l'ordre social" (I777).

\section{L'impôt.}

Taxes are the common debt of the citizens, a kind of indemnity (dédommagement), and the price of the advantages which Society procures for them. Taxes are no more than advances to obtain the protection of social order, contributions imposed by all on each.-Mirabeau, in a document of the Assembly, written in I789. Quoted by Leroy Bœaulieu, “Traité de la Science des Finances, I. I46. Also in his "Addresse aux Français" (I789).

\section{Impôt.}

The common debt of the citizens, and the price of the advantages which society procures for them."-Assemblee Nationale, "Addresse aux Français" (I789).

\section{Impôt.}

A $\operatorname{tax}($ impot $t)$ is a part of the yearly income of each citizen, which he is obliged to give up for the expenses necessary to safety, tranquillity, liberty, public prosperity; that is to say, for the maintenance of his own rights, for the preservation of the advantages he obtains from society.-Condorcet, " Des Lois Constitutionnelles sur l'Administration des Finances" (I790).

\section{L'Impôt.}

Taxation is an exchange in which the State gives services and the contributor money.-(Reference lost. The quotation is retained here as it is quite a typical I8th (and early Igth) century definition).

\section{L'Impôt.}

A tax is a value surrendered to the government by individuals, 
to help the public expenses. It is measured by the sacrifice demanded of the contributor, and not by the sum which the government receives; so that the expenses of collection, the time lost by the contributor, the personal services demanded of him, etc., form part of the tax. The value ... which is sacrificed by the contributor ... is not returned to society. It is consumed to satisfy the needs of the public, and consequently is destroyed. . . . Society is indemnified for the sacrifices that taxes cost, by security, and by any enjoyments that they procure for society. If the enjoyments could have been obtained more cheaply, society has made a bad bargain.-J. B. Say, "Traité d'Economie Politique," III. 294 (I803).

\section{Impôt.}

Taxation (l'impott) is that part of the produce of a nation, which passes from the hands of individuals to the hands of the government to support public consumption. Whatever may be the name we give it, contribution, taxe, droit, subside, don, gratuit, it is a charge imposed on individuals, or on groups of individuals, by the sovereign, people or prince, to furnish those consumptions which he thinks fit to make at their expense : this is then, a tax (impôt).-J. B. Say (ibid.).

"A tax (impôt) is that part of the goods of individuals which the government devotes to satisfying its desires or the needs of the social body." -J. B. Say (ibid.), (1803).

\section{Impôt.}

Taxes ( $l^{\prime}$ impôt $)$ should be considered by the citizens as a payment for the protection which government gives to their persons and properties.-Simon de Sismondi, "Nouveaux Principes de l'Economie Politique" (I8Ig).

Impôt.

The annual demand made by the State, of a certain portion of their incomes from all those judged to have any."--Rossi, "Cours d'Economie politique," IV. I (I839-I84I).

Impôt.

Taxes (impôt $)$ are demanded essentially from the social revenue and originate in the right of the State to claim its share in the distribution of the general net produce, in the distribution of the social revenue.-Rossi (ibid.), (I839-I84I).

Impôt.

Taxation (l'impôt) is the sacrifice of a part of property to preserve the rest.-G. du Puynode (Partounan du Puynode), "De la monnaie, du crêdit, et de l'impôt" (I853). 
Impôt.

A $\operatorname{tax}(i m p o t)$ is the part paid by each citizen of the expense of the public services. Taxation is an exchange of services.Proudhon, P. J., "Théorie de l'impôt" (I86r).

Impôt.

Taxation is the price of the protection granted by the State to the goods of the contributors.-E. de Parieu, " Rapport sur l'impôt sur les successions" (I862).

Impôt.

A tax (impôt) may then be defined thus: the demand made by the State on the fortune or the labour of the citizens to support the public expenses.-E. De Parieu, "Traité des Impôts" (I862).

De Parieu groups together-

(a) Tributum, vectigal, abgabe, gabelle, contribution, dazio, indicating the gift made by the individual to society.

(b) Auflage, duty, impot, referring to its obligatory nature.

(c) Taxatio, schatzung, skatt, szos, taxe, indicating its fixity, or the valuation serving as its basis.

(d) Steur, hjelp, aide, indicating the help to the individual coming from the existence of the social body (1862).

Impôt.

Taxation (l'impot $t$ ) is in fact, the prepayment taken from the fortunes of individuals by the government of the State, province or commune, to support the public expenses, that is to say, to pay the officials, and to pay the other expenses necessitated by the functions attributed to it, and the services with which it is charged."-J. Garnier, "Traité des Finances" (I862).

Taxation ( $l$ 'impôt) is the price of services rendered, and especially the price of security, a service of universal interest-or, the premium paid for the guarantee of security-this word security being taken in its general sense of guarantee of protection, law, justice, order, property, individual liberty, national independence, and the equitable execution of laws and contracts.- J. Garnier (ibid.).

Impôt.

A tax (impôt) is a share of individual resources put at the disposition of the sovereign power.-Clamageran, "Histoire de l'impôt en France" (1867-1876).

\section{Impôt.}

Taxes (l'impôt) represent the putting into value and the 
general expenses of exploitation of the national capital.-E. Menier, "Thêorie et Application de l'impôt sur le capital " (I874). Impôt.

A public charge, a claim (droit) imposed upon certain things. _ "Dictionnaire de l'Académie française" (I878).

A public charge, a claim imposed upon certain things to support the expenses of the State.-Bescherelle Aîné, "Nouveau Dictionnaire National" (I887).

A public charge, a claim imposed on certain things. More especially in legislation, of taxes (impôts) in general and of the manner of establishing them.- "Nouveau Dictionnaire de l'Acadêmie française."

A public charge, a claim imposed on certain things.-E. Littré, "Dictionnaire de la langue française" (I863).

\section{L'impôt.}

Taxes represent the general working expenses incurred, in the employment of the national capital.

The only tax which conforms [to these rules and] to this definition is a tax on fixed capital.

In the above definition of taxation, it is the collective part [of capital] alone to which we refer.-Yves Guyot, " Principles of Social Economy" (tr.), VI. 282 (I884).

\section{Impôt.}

A tax (impott) is a deduction made in the name of the State from the resources of its members to contribute to the expenses of government. - " La Grande Encyclopêdie" (art. by Berthelot). (Undated. Published during the latter part of the Igth century.)

\section{L'Impôt.}

A tax (impôt) is a deduction (prélèvement) from the individual powers of the contributors, to support the expenses of the public services." - Renê Stourm, " Nouveau Dictionnaire d'Economie Politique," ed. Say and Chailley (I892).

\section{L'Impôt.}

A tax (impôt), is a deduction from possessions, to which individuals have been or are compelled to submit, under different forms and at different times, fixed or periodical, whether to the profit of the State, or to the profit of other forces, of other members of the nation, of other peoples and states.-E. Fournier de Flaix, " $l$ 'Impôt dans les diverses civilizations," Introduction, VIII. (I897). 


\section{L'Impôt.}

Taxes (l'impôt), as understood by civilized peoples to-day, can be defined as the monetary contributions which governments demand from individuals as an accomplishment of their duty of social solidarity.-Boucard et Jèze, "Science des Finances," II. III. I. (Ig04).

\section{L'Impôt.}

The essential characteristics of a tax (l'impôts), as they separate themselves from fact, are then (I) the accomplishment of the duty of social solidarity; (2) the individual character of the payment (prestation); (3) the obligatory character ; (4) the pecuniary character of the contribution; (5) the establishment of the tax by the governors. [No. (I) is marked as the fundamental notion] Ibid. II. iii. I $\S$ I.

Under the name of taxes (impôts) must be included fiscal fees (rétributions) and taxes proper. A fee is distinguished from a tax in that it is collected on the occasion of a definite service rendered by the State, whilst a tax is laid on without consideration of any special service. But this difference is of slight importance, for in the case of fiscal fees, the fiscal side greatly preponderates.-Ibid. II. iii. Preliminary (Ig04).

\section{Impôt.}

We call taxes (impôt) the contribution demanded from each inhabitant of a country as his quota of the expenses of the State.C. Colson, "Cours d'Economie Politique," Vol. III. Bk v. iv. I (Ig05).

\section{Impôt.}

$A \operatorname{tax}(i m p \hat{o} t)$ is the contribution demanded from each citizen for his part in the expenses of government. If this formula seems too modest and too empirical, we may have recourse to the following. A tax is the price of services which the State has rendered: it represents moreover the part that each citizen, by the application of the principle of national solidarity, should bear in the charges of every kind and of every origin, "weighing upon the State."-Leroy-Beaulieu, "Traité de la Science des Finances," 7 th edition, Vol. I. p. I5I (I906).

\section{§ 5. STEUER.}

The word originally signified a help or support, like the cognate word "steuer," a rudder. Both words give the derivative notion of an aid, as does also the older English term for a rudder, "steering board," which has been modified and altered into starboard. 
Later developments are illustrated by the following words-

$\begin{array}{llll}\begin{array}{l}\text { German } \\ \text { Bede }\end{array} & \begin{array}{c}\text { French } \\ \text { aide }\end{array} & \begin{array}{l}\text { Italian } \\ \text { dazio }\end{array} & \begin{array}{c}\text { English } \\ \text { hilp }\end{array} \\ \text { Abgabe } & \text { impôt } & \text { tributo } & \text { tax } \\ \text { Schoss } & \text { imposition } & \text { imposto } & \text { duty } \\ \text { Schátzung } & \text { contribution } & \text { imposizione } & \\ \text { (Herd)-geld } & & \text { tassa } & \\ \text { (Un)-geld } & & & \\ \text { Auflage } & & & \\ \text { Umlage } & & & \end{array}$

Condensed from the "Handwörterbuch der Staatswissenschaft," Dr. J. Conrad and others (I898-I900).

\section{A Chronological List.}

Steur.

Lat. Census, Tributum, Collecta, or also Steura.

This word is generally used to cover all contributions made by subjects, rendered as a duty, and may equally be a poll-tax on persons or a charge laid on goods.-Zedler, "Universal Lexicon" (Leipsig und Halle, I744).

\section{Steuern.}

If the imposts (Auflagen) are measured according to economic circumstances (wirtschaftlichen Umstande), that is, according to the means of the citizen, so that a heavier impost (Abgabe) is laid, the more prosperous the payer is, and the more easily he can pay, then we have taxes (Stewern).-Dr. K. H. Rau, "Grundsätze der Finanzwissenschaft," forming Vol. III of "Lehrbuch der politischen Ekonomie," Part I. § 86 (1832).

\section{Steuern.}

The contributions which individual economies must pay, in consequence of their dependence, to the State, province, commune, etc., or, generally, the particular collective compulsory economy placed over them, in order to assist in satisfying the financial needs of the receivers.-Roscher, "Finanzwissenschaft," $\$ 33$ (I878).

\section{Steuern.}

A definition [of taxes] satisfactory in science and practice, must first of all include four characteristics, two positive, two complementary and negative; taxes (Steuer) must be characterized positively as revenue (Einnahme) in the finance of a public body, the State or other, and further as a specific, peculiar appropriate revenue, in the last regard therefore, on the ground of the 
classification of income mentioned; and negatively must be definitely and recognisably marked out as a part clearly marked off and differentiated from private incomes and from fees (Gebühren).-Wagner. " Finanzwissenschaft," II. 205 (2nd edition, I883).

Steur.

The tax (steuer) is a payment made by members of a political community towards its expenses, simply in virtue of their being members, and without its being possible to balance accounts as regards particular expenditures and the particular benefits accruing to individual members.-G. Cohn, "Finanzwissenschaft," Vol. II. of " System der Nationökonomiє," § 99 (I889).

\section{Steuern.}

" Or the State demands economic services for general purposes without (such) special services in return, as a duty of citizenship, according to a general standard,-taxes (Stenern); which are duties (Abgaben) imposed on individuals to meet the general needs of the State.-F. H. Gesscken, in Schönberg's "Handbuch der Politische Ekonomie," Vol. III. Part I. i. I (4th edition, I897).

Gesscken also quotes v. Mayr's very simple definition, as an example of undesirable simplicity - "Taxes are general moneycontributions (Geldbeiträge)." This recalls the definition of an earlier edition of the "Dictionary of the French Academy" " Taxation is a public charge, a duty imposed on certain things."

\section{Steuern.}

Taxes in a purely financial sense are those impositions (Auflage) or amounts rendered (Abgaben) which are demanded as forced contributions from individual economies for the service of the general public economy.-Prof. Conrad, "Finanzwissenschaft," II. 2 IO.

Taxes are forced contributions to the State funds, which the State raises from private economies, according to a general legal standard, without offering an immediate equivalent for it, as is the case in the levy of income tax, customs, etc.-Prof. Conrad, "Grundriss," III. p. 5 (I903).

\section{Steuern.}

Taxes are what is compulsorily taken from private incomes, without any definite services being rendered in return, for the expenditure of the community. Logically, they are sharply separated from Fees (Gebühren) as the community does not earn them as it does Fees, by offering single definite services.-Dr. R. van der Borght, " Finanzwissenschaft," II. I (Ig08). 


\section{§ 6. A FEW OTHER TERMS, WITH A NOTE ON INCORRECT DEFINITIONS.}

$\operatorname{Tax}(?)$.

Let the king make the common inhabitants of his realm who live by traffic, pay annually some trifle, which is called a tax."The Laws of Manu," III. I37, circa 500 B.c.

[I do not know the term here rendered by " tax," The quotation is from "The Sacred Books of the East."]

Tax (Chinese terms).

Some information in regard to the development of taxation is given in the terms applied to the tax systems of the Three Dynasties. According to Mencius, the tax system of the Hsia dynasty was called kung, "tribute" ; that of the Yin dynasty, tsu, " assistance" ; and that of the Chou dynasty, ch'é, " assessment." Mencius does not explain the word kung, because it is clear by itself. He comments on the other two words as follows: "Ch'é means an exaction [from the people] and tsu means dependence [of the government]."

[Hsia dynasty, B.C. 2205-I766.

Yin dynasty, B.C. I766-II22.

Chou dynasty, B.c. II22-249.]

-Dr. Chen Huan-Chang, "The Economic Principles of Confucius and his School," Columbia University (IgII).

Tributa.

"For taxes (tributa) moderately imposed, and faithfully laid out in the service of the public, are only the wages (merces) which every man pays the state for the defence and security of himself and his property; and to maintain the expenses unavoidably necessary to that end.-Baron S. Pufendorf, "De Jure Naturæ et Gentium," VIII. vi. 4 (1672).

Gebühr (pl. Gebühren).

I. Duty, devoir, due, office.

2. Decency, decorum, seemliness.

3. Fee.

4. Moderation, measure, bounds.

"Gebühren an die Obrigkeit" (fees to the authorities), tribute, taxes.-Flügel's Dictionary (I843 edition).

\section{Gebühren.}

Fees (Gebuihren) have developed for the most part from perquisites (Sporteln) ; they are taxes (Abgaben) which are paid not to the official organ, but to the personal official who performs certain services for the public, as a supplement to his insufficient 
salary.-Dr. J. Conrad. " Grundriss zum Studium der Politischen Ekonomie." III. I. vi. §6o (I903).

\section{Gebühren.}

Fees (Gebühren) are immediate compensations for such individual services of the public organ, given willingly, or indeed unwillingly, but occasioned trading-fashion, and bearing a claim on definite official acts, or the services of certain public institutions and organisations, not bound up with peculiarly economic (wirtschaftlicher) activity.-Dr. R. van der Borght, " Finanzwissenschaft, I. vi. § I6 (Ig08).

\section{Tax.}

(tassa ?) - tax is that part of the wealth of private individuals which the authority of the State, province, or municipality appropriates in order to provide for the public expenses incurred for the advantage of the general body of taxpayers.-Prof. Cossa, "Introduction to the Study of Political Economy" (Engl. translation, I893. Third volume of " Elements" translated I888. The works were written in the seventies and eighties. I have not been able to trace the original passage).

\section{Tributo.}

A tax (tributo) therefore is a portion of each individual's property placed in the public treasury in order that the remainder may be enjoyed in security.-P. Verri. "Meditazioni sulla Economia Politica" (I772).

\section{Contribuzioni. Dazi. Imposte.}

Each of us enjoys the guarantees given to property, each feels that he lives under settled laws, that wise government is a great advantage ; and it is just then that each should contribute to the maintenance of the government. Hence these payments are called contributions (contribuzioni).-Ant. Scioloja, "I Principii della Economia Sociale," VI. i. § I (I840).

The 3rd Edition ("Edizione Torinese," I848) here adds-

"They are also called taxes (dazi) or imposts (imposte) according as they are regarded as parts of wealth given up (data) or as being forced payments (costrello) to the government."

\section{Tassa. Imposta.}

Taxes (le tasse) are the equivalents of services received from the State by individual members; whilst imposts (imposte) are general contributions paid for indivisible public services-F. S. Nitti, " Lezioni di Scienza delle Fin anze," II. vi. p. 233 (I902). 
Tassa.

Taxes (tasse) form a portion of the cost of general services (divisible and) divided among individual citizens, who help by their effective consumption the public services.-F. Flora, "Manuale di Scienza delle Finanze" (Ig03).

[See his definition of Imposta, below.]

Imposta.

Imposts (imposta) are a part of the cost of general public services, indivisible, compulsorily levied by the State upon the wealth of all its members.-F. Flora, "Manuale di Scienza delle Finanze" (I903).

[The element of compulsion, absent from the definition of tassa, is here emphasized, and is related to the indivisible nature of certain charges made by [the State.]

Incorrect Definitions.

(Leroy-Beaulieu, I. Vol. 2. I. p. I47.)

(I) Taxes are an exchange of services.

(2) Taxes represent the premium of an insurance paid to guarantee security.

(3) Taxes represent the setting 'in motion and the general expenses of exploitation of national capital.

His Replies.

(I) What about public debts? "The conception of taxes as the simple price of equivalent social services would lead to the theory of the repudiation of national debts."

It is true only " in the general, not in the special sense."

(2) The State is not " a mere gendarme." Also, the comparison is false because the State does not make losses good, as does an insurance company.

(3) Ménier's definition is a part of his theory of a single tax on capital.

The definition pre-supposes a proper use of national capital by the State (Fr. exploitation). L.-B. thinks it would not cover ill-advised expenditure. The definition is given on pp. 262263. 


\section{Appendix II.}

\section{A NOTE ON FAMILY BUDGETS AND TAXES.}

SEVERAL attempts have been made from time to time to assess the amounts paid in taxes by representative people of various classes. According to the ideas expressed in this book, it would be still more useful to trace the amounts of pure tax that are paid. This, however, is a much more difficult thing. So long as we are dealing with gross taxes of all kinds, as paid, the question is only one of statistics, but there is no known criterion by which we can divide a Sanitary Rate or an Education Rate into definite payments for definite services, and definite payments for indefinite services.

But the simpler calculation, that of reckoning out the amounts paid in gross rates and taxes by "typical people" of different classes, yields results that are of very limited utility. It is very difficult indeed to find a "typical man" of any class A farmer, a Civil Service clerk, and a shopkeeper, pay their rates under conditions so different that if their incomes were equal to say $£ 400$ a year, they would by no means pay equal amounts in rates. The farmer, under the Agricultural Rates Act of I896, is assessed at half the ratable value of his farm for general purposes, and by the Health Acts of I848 and I875 at a quarter of the ratable value for public health and lighting services (District rate). The clerk and the shopkeeper pay upon the full ratable value of their assessments. The shopkeeper pays rates on his house-rent and on his shop-rent, whether these are two amounts or one. He will probably be paying far more in rates than the clerk or the farmer; and the clerk and shopkeeper will be paying more per pound of ratable value than the farmer.

We cannot assume, moreover, that these are real payments in the sense of ultimate payments. The farmer and shopkeeper can and will shift the rates they pay on to the people who buy, from them, and the usual tangle of "shifting and incidence" results.

The farmer, again, needs a very large area of land for his work, the shopkeeper less, the clerk still less. The clerk might point out that he pays income tax to the full, for his income 
is known, whilst the incomes of the farmer and shopkeeper are not always very clearly known, even to themselves, and he might suggest that if they err in stating it for Inland Revenue purposes, they probably err, being human, in quite a human manner. Here the shopkeeper might call attention to the fact that the farmer since I896 (Agricultural Rates Act) is relieved from more than half his rates. And all these mingled inequalities are to be balanced against the varying benefits received, in the three cases, from the expenditure of the rates.

It may be that such inequalities, since they are not all on one side, as these examples show, average themselves out to some sort of rough justice. But there is no reason why they must. If the injustices balance each other, it is partly by chance and partly by the working of the slow semi-conscious adjustment that characterises all old human institutions : an adjustment made by taking off a little here, putting on a little there, until the mass of balances, exceptions, additions, allowances, and other changes and counter-changes grows so complicated that it is all revised or codified upon a simpler basis.

There are difficulties in the way of reckoning and how the gross rates and taxes are distributed among individuals and among classes. There are difficulties in deciding on representative or typical individuals for these classes; and further difficulties in separating out the pure taxes from the gross rates and taxes paid. This last calculation would relate directly to the scope of this book, and was at first projected. We have outlined enough of the difficulties in the way to show why the idea of including such an assessment in this work was abandoned. The inquiry has its own fascination, however. We should most of us like to know how much real (pure) taxes we actually pay -and no doubt attempts will be made. In any such attempt (one giving, say, (I) income, (2) gross taxes, (3) pure taxes, in parallel columns) it would be very necessary that the considerations which led to $f y$ of pure tax being separated out from $£ x$ of total tax should be clearly stated. Assessments made by people of different political views would probably not coincide. We shall be content here to quote some of the attempts that have been made at assessing gross "taxes."

Joseph Massie published in I756 a work with the title "Calculations of Taxes for A Family of each Rank, Degree or Class for One Year." He gives in all thirty cases, from which we here select four, numbered $I, 7, I 6$ and 30 in his tables, thus :- 
(I) A Nobleman with an income of $£ 20,000$ a year,-evidently a large landowner, as he pays $£ 4,000$ land-tax.

(7) A Gentleman; income $£ I$,ooo per year.

(I6) A Farmer; income fioo a year.

(30) A Husbandman, or Labourer in the Country; income fI3 a year (5s. per week).

\begin{tabular}{|c|c|c|c|c|}
\hline \multirow{2}{*}{ (a) Taxes Paid on } & \multicolumn{4}{|c|}{ By Persons having Incomes } \\
\hline & $\begin{array}{c}(I) \\
\text { of } £^{20,000} \text {. }\end{array}$ & $\begin{array}{c}(7) \\
£ \mathrm{I}, 000 .\end{array}$ & $\begin{array}{l}\text { (r6) } \\
\text { froo. }\end{array}$ & $\begin{array}{l}(30) \\
\text { fI3. }\end{array}$ \\
\hline $\begin{array}{l}\text { Malt, Beer, etc. } \\
\text { Salt } \\
\text { Sugar, Currants, etc } \\
\text { Leather } \\
\text { Soap and Candles } \\
\text { Coals (in London) } \\
\text { Houses and Win- } \\
\text { dows. } \dot{\text {. }} \cdot \\
\text { Drugs, Tobacco, } \\
\text { Glass, Stamps, } \\
\text { etc. } \dot{\text { Land }} \text { (4s. in } £)\end{array}$ & $\begin{array}{rrr}\underset{f}{f} & s . & d . \\
68 & 18 & 0 \\
4 & 8 & 4 \\
7 & 19 & 0 \\
3 & 10 & 8 \\
15 & 8 & 0 \\
8 & 0 & 0 \\
20 & 4 & 0 \\
& & \\
& & \\
500 & 0 & 0 \\
4,000 & 0 & 0\end{array}$ & $\begin{array}{rrr}\underset{1}{f} & s . & d . \\
\mathrm{II} & \mathrm{I} & 0 \\
0 & \mathrm{I} 4 & 2 \\
\mathrm{I} & 5 & 6 \\
0 & \mathrm{II} & 4 \\
2 & \mathrm{II} & 0 \\
2 & \mathrm{I} 6 & 0 \\
& & \\
5 & 4 & 0 \\
& & \\
25 & 0 & 0 \\
200 & 0 & 0\end{array}$ & $\begin{array}{rrr}t & s . & d . \\
2 & \mathrm{I} 4 & 0 \\
0 & 5 & 10 \\
0 & 4 & 0 \\
0 & 4 & 0 \\
0 & 5 & 2 \\
0 & 8 & 0 \\
0 & 7 & 9 \\
& \end{array}$ & $\begin{array}{ccc}E & s . & d . \\
0 & 4 & 7 \\
0 & 3 & 4 \\
0 & 2 & 0 \\
0 & 2 & 2 \\
0 & 1 & 3 \\
& - & \end{array}$ \\
\hline $\begin{array}{l}\text { Wines, Rum, Cof- } \\
\text { fee, Tea, etc. } \\
\text { Foreign Silks, } \\
\text { Linens, etc. }\end{array}$ & $\begin{array}{rrr}4,628 & 18 & 0 \\
1,500 & 0 & 0 \\
250 & 0 & 0\end{array}$ & $\begin{array}{ccc}249 & 3 & 0 \\
75 & 0 & 0 \\
\text { I2 } & 10 & 0\end{array}$ & $\begin{array}{lll}4 & 89 \\
\text { I } & 34 \\
\text { O } & 3 & \text { II }\end{array}$ & $\begin{array}{c}\text { O } 5 \text { ro } \\
- \\
-\end{array}$ \\
\hline Total Taxes & $\begin{array}{l}f^{6,378} \text { i } 8 \text { o } \\
=6 / 5 \text { in the } \\
t \text { on Income. }\end{array}$ & $\begin{array}{l} \pm 336 \text { I3 o } \\
=6 / 9 \text { in the } \\
\pm \text { on In- } \\
\text { come. }\end{array}$ & $\begin{array}{l}£ 5 \text { I6 } \\
=\mathrm{I} / 7 \text { in } \\
\text { the } £ \text { on } \\
\text { Income. }\end{array}$ & $\begin{array}{l}\text { fo } 15 \text { ro } \\
=\mathrm{I} / 3 \text { in } \\
\text { the } f \text { on } \\
\text { Income. }\end{array}$ \\
\hline
\end{tabular}

The poundage rates on income given at the bottom of each column recall some of the arguments that have been used in the discussion of the respective claims of proportional and progressive rates. The argument for progressive taxation is usually conducted on the implied assumption that pure taxes are being considered. Apart from the difficulty of finding any definite progressive scale, there is to be considered the difficulty, when a scale for pure taxes is fixed, of finding any corresponding scale for general mixed taxes. No solution offers itself: 
With this in our minds, as a corrective against hasty deductions of any kind, we may set Massie's poundage rates against those of the Income Tax as fixed in the Budget of I909.

\begin{tabular}{|c|c|c|c|c|}
\hline \multicolumn{3}{|c|}{ Income. } & $\begin{array}{l}\text { Payments in the Pound } \\
\text { in Massie's Calculations }\end{array}$ & $\begin{array}{l}\text { Payments in the Pound } \\
\text { on Income (1909 Budget). }\end{array}$ \\
\hline $\begin{array}{r}\underset{13}{13} \\
100 \\
1,000 \\
20,000\end{array}$ & $\begin{array}{l}\cdot \dot{ } \\
\cdot \dot{\cdot} \\
\dot{\cdot}\end{array}$ & $\begin{array}{ll}\cdot & \bullet \\
\cdot & \cdot \\
\cdot & \bullet \\
\cdot & \bullet \\
\cdot & \bullet\end{array}$ & $\begin{array}{l}\text { Pence. } \\
\text { I3 } \\
\text { 19 } \\
8 \text { r } \\
79\end{array}$ & 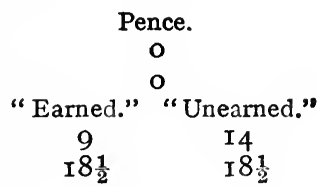 \\
\hline
\end{tabular}

II.

Another attempt was made in a work published in I833, and again (Third Edition) in I835. The book is a "History of the Middle and Working Classes," by John Wade. In an appendix there are four family budgets given-

Per Week.

s. $d$.

(I) Expenses of the Family of an Agricultural Labourer in 1762-[London Magazine for 1762$]$.

(2) The same, on an average of 65 families (working out to $5^{\frac{4}{5}}$ persons per family) [Cases collected by Sir F. Eden in I796] . . . . . . II $3 \frac{1}{4}$

(3) Expenditure at a Grocer's Shop-Labourer, Wife, and 6 children [" Poor Law Commission Report," p. 25I, I833].

(4) Proper Food for an Able-bodied Labourer, with a wife and 4 children, per week. ["Plain Statement of the Case of the Labourer," p. 23, London, I83I] . . I7 o

This last is worked out to show the proportion of "tax or monopoly "- the latter referring to the effects of the monopoly of the East India Company. The basis of the assessment of tax is explained thus.

(a) Duty on wheat, 25s. to Is. per quarter, as prices change from 6Is. to 70s. a quarter.

Duty on bacon, 28s. per cwt.

Duty on butter, 20s. per cwt.

Duty on cheese, Ios. $6 d$. per cwt.

These are taken together in the account given below, and the writer says, on the basis of these duties, "It is not too much, then, to say, that one-third of the weekly outgoings of a labourer in bread, bacon, butter, and cheese, is caused by agricultural taxes." 
(b) "The duty on tea is 96 per cent., ad valorem, and Ioo per cent. on all teas sold above $2 s$. per lb., at the East India Company's sales." (The duty was lowered in I834 to Is. $6 d$. per lb. on low-priced teas, and raised after I836 to $2 s$. Id. on all teas. A full account is given in Sir S. M. Peto's "Taxation," I863.) The effect of the Company's monopoly is reckoned at $9 \frac{1}{2} d$. or rod., being the difference between the price at the Company's sales (Is. 6d. to Is. $7 d$.) and the prices at Hamburg and New York $\left(8 \frac{1}{2} d\right.$. or $9 d$.).

Duty on foreign coffee, Is. $3 d$. per $1 \mathrm{~b}$.

Duty on British plantation coffee, $6 d$. per lb.

From these figures the writer reckons "Two-thirds, therefore, of the labourer's expenses in the tea or coffee pot may be traced to political causes."

(c) "Duty on West India sugar, 24s. per cwt., or $2 \frac{8}{11} d$. per 1b. ; on East India, 32s. per cwt., or $5^{11} \frac{1}{2}$ per pound.

(d) Duty on malt, 20s. $8 d$. per quarter; on hops, $2 d$. per $1 \mathrm{~b}$.

(e) Duty on hard soap "which is that commonly used," $3 d$. per lb. (about roo per cent.); on tallow, $3 s .4 d$. per cwt.; on barilla, 2s. per cwt. ; on turpentine or rosin, $4 s .4 d$. per cwt. : these being substances from which soap is made.

(e) Local London duty on coals, I3d. a chaldron, or about a farthing per cwt.

The following is the labourer's budget (No. 4, above) with the tax as reckoned on the bases given.

Proper Food for an Able-bodied Labourer, having a Wife ANd Four Children, Per WeEk; With the Proportion of the Price of Each ARticle of Provision occasioned by TAX OR MONOPOLY.

5 gallons of bread.

3 lb. of bacon at $7 d$. per lb. . $\quad$ I 9

2 lb. butter at rod. . . . . $\quad$ I 8

$2 \mathrm{lb}$. cheese at $6 d . . . \quad . \quad . \quad . \quad$ I 0

Tea (evidently $\frac{1}{4} \mathrm{lb}$.) . . . . $\quad$ o 9

Sugar (I lb.)

7 quarts beer, at $2 d$. quart . . $\quad$ I 2

I bushel of coals . . . . . . . $\quad$ I 2

3 faggots . . . . . . . . . $\quad$ o 9

$\frac{1}{2}$ lb. soap . . . . . . . . $\quad$ o 4

$\frac{1}{2} \mathrm{lb}$. candles

Tax and

Monopoly.

o 4


A comparison is made between cases (I) and (4), the duties in the former case being reckoned thus-malt, $4 s .2 d$.; salt Is. $8 d$.; soap and candles, $3 s$.; leather, $2 s$.; sundries, $2 d$. Total, IIs. for the year on these items. The author reckons that labourers paid in taxes about one-thirty-sixth part of the weekly expenditure in $I 762$, and, leaving out " the agricultural taxes and the Ioo per cent. addition to tea occasioned by the monopoly of the East India Company," one-fourteenth in I83r.

\section{III.}

When Mr. Robert Lowe in I87I proposed (and abandoned) a match-tax, Professor Stanley Jevons discussed the project in a pamphlet ("The Match Tax : A Problem in Finance ") issued in the same year, and afterwards included in the volume called "The Principles of Economics." To this pamphlet there is an appendix, called " Estimates of Taxation," dealing with three imaginary families, "supposed to expend in the year $£ 40, £ 85$, and $£ 500$ respectively." Each family is assumed to consist of "man and wife, one child over ten years of age, and one under that age, this being the family which most nearly represents the average composition of the population. Their consumption is taken equal to that of $3 \frac{1}{2}$ adults. 'The family expending $£ 500$ a year is supposed to include also 3 adult servants, making altogether $6 \frac{1}{2}$ adults." It may be noted that the relatively ${ }_{\alpha}$ larger ${ }^{*}$ families in the poorer classes is a fact not taken into account, and to some extent this will affect the results of the inquiry. 
Thing Taxed, and Rate.

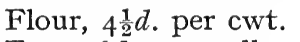
Tea, $6 d$. per lb., reckoned at $7 \cdot 4 d$. (because of licences and profits) . . Coffee, $4 d$. per $1 \mathrm{~b}$. (with licence, $4 \cdot 8 d$.) Sugar, $\mathrm{I} d$. per $1 \mathrm{~b}$. (with profit, $\mathrm{I} \cdot 2 d$.) Fruits, $7 s$. per cwt. (with profit, I.9d. per lb.)

Rates, at $45.6 d$. in $£$ (on rents of $£ 54 s$. fIO 8s. and $£^{6} 3$ respectively).

Beer (tax with profits, $\frac{2}{3} d$. per qt.) .

Spirits (duty, licence and profits, r2s. $9 d$. per gallon)

Wine (total, I3.2d. per gallon) .

Tobacco (with profit, 4 s. per lb.)

Income $\mathrm{Tax}$, at $5 d$. in $€$. . .

House Duty, at $9 d$. in $€$. . .

Insurance, Is. $6 d$. on $\stackrel{£ 800}{\text { Legacy Duty on } £ \text { roo }}$
Families expending, per year,

\begin{tabular}{|c|c|c|c|c|c|c|c|c|c|c|c|}
\hline \multicolumn{4}{|c|}{$£ 40$ (I 5s. week). } & \multicolumn{4}{|c|}{$f_{85}$ (33s. week). } & \multicolumn{4}{|c|}{$£ 500$. } \\
\hline$£$ & $s$. & $d$. & $\begin{array}{l}\text { Per } \\
\text { cent. } \\
\text { of in- } \\
\text { come }\end{array}$ & $£$ & $s$. & $d$. & $\begin{array}{l}\text { Per } \\
\text { cent. } \\
\text { of in- } \\
\text { come }\end{array}$ & $£$ & $s$. & $d$ & $\begin{array}{l}\text { Per } \\
\text { cent. } \\
\text { of in- } \\
\text { come }\end{array}$ \\
\hline o & 4 & 6 & $\cdot 5^{6}$ & 0 & 3 & 8 & $\cdot 22$ & $\mathrm{O}$ & 4 & 9 & $\cdot 0_{j}$ \\
\hline 0 & 3 & 6 & $\cdot 44$ & o & 7 & I & $\cdot 4 \mathrm{I}$ & I & 12 & o & $\cdot 32$ \\
\hline & $\longrightarrow$ & & - & $\mathrm{O}$ & 4 & 6 & $\cdot 26$ & 0 & IO & 5 & $\cdot$ IO \\
\hline o & 9 & 0 & $I \cdot I 2$ & o & I 3 & 8 & $\cdot 80$ & I & I 3 & 9 & $\cdot 34$ \\
\hline & $\longrightarrow$ & & - & 0 & 0 & 9 & $\cdot 05$ & O & 2 & 0 & .02 \\
\hline I & O & O & $2 \cdot 5$ & 2 & $\mathrm{O}$ & o & $2 \cdot 4$ & 9 & 9 & 0 & $I \cdot 9$ \\
\hline I & 0 & 4 & $2 \cdot 5$ & I & O & 4 & $\mathrm{I} \cdot 2$ & & & & \\
\hline & - & & - & I & 5 & 6 & $\mathrm{I} \cdot 5$ & 9 & 0 & 0 & $x \cdot 8$ \\
\hline I & 4 & O & $3^{\circ} \mathrm{O}$ & I & 4 & o & $I \cdot 4$ & & & & \\
\hline & - & & - & & - & & - & IO & 8 & 4 & $2 \cdot I$ \\
\hline & - & & - & & - & & - & 2 & 7 & 3 & 5 \\
\hline & - & & - & & - & & - & 0 & 12 & 0 & $\cdot \mathrm{T}$ \\
\hline & 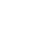 & & - & & - & & - & 3 & 17 & 0 & $\cdot 8$ \\
\hline$£ 4$ & I & 4 & $\begin{array}{c}\text { IO'I I } \\
\%\end{array}$ & $t^{6}$ & I9 & .6 & $\begin{array}{c}8 \cdot 2 \\
\%\end{array}$ & $£ 39$ & I6 & 6 & $\begin{array}{l}8 \\
\%\end{array}$ \\
\hline
\end{tabular}

IV.

In an article called " The Incidence of Taxation in the United Kingdom" (Yale Review, Feb., I898), Mr. C. P. Sangar gives the 
following results of his calculations and inquiries upon proportionate payments of taxes. Basis: "Calculated average consumption per head in the working classes to roughly correspond with my estimates."

Tea

Beer

Spirits (excise)

Coffee

(imported) .

Chicory

Cocoa, etc.

Currants

Figs, prunes, raisins, etc.

Tobacco

[Some of these figures seem rather small for annual amounts!]

Estimated Incidence of Imperial Public Burdens in the United Kingdom in Millions of Pounds.
Per head per annum.

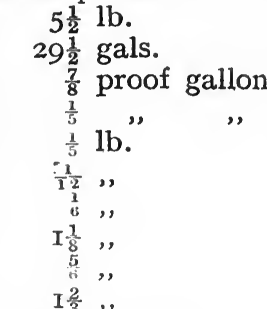

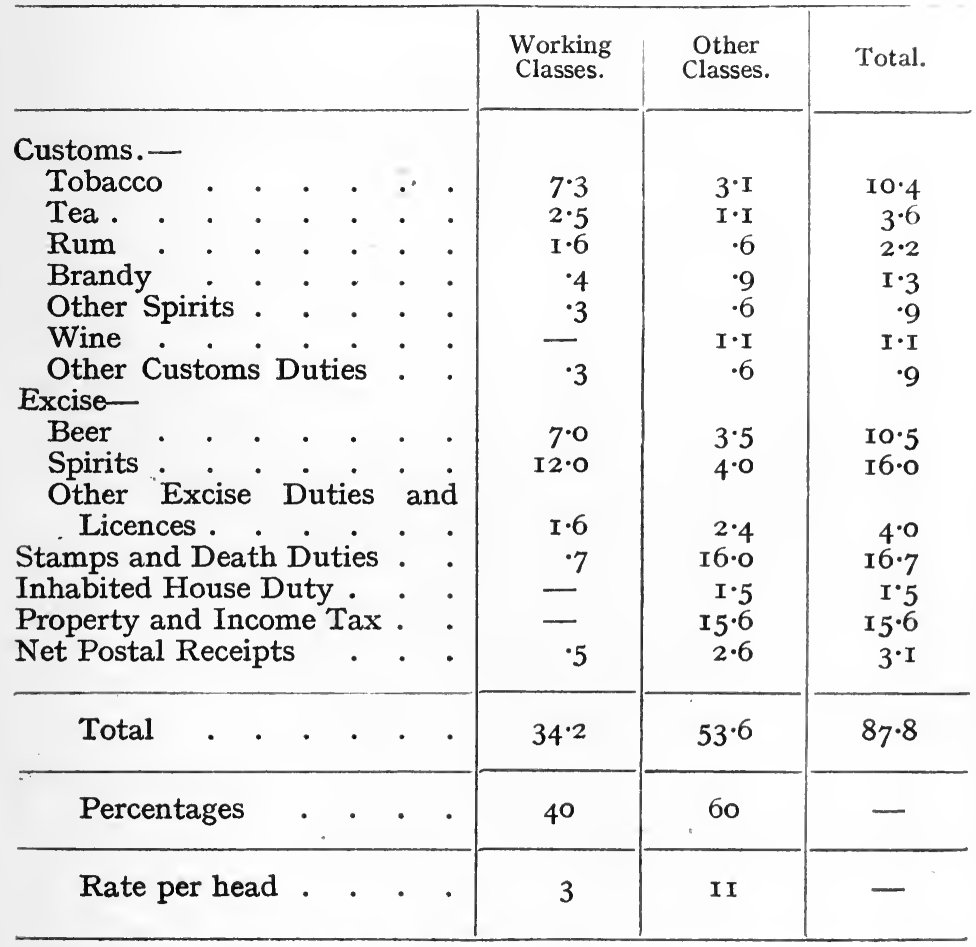

Local Public Burdens are reckoned as being distributed thusWorking Classes, £7,280,7I8. 
Other Classes, $£ 31,511,870$.

Ratio per head, I: Io.

Total Public Burdens, imperial and local, are assessed per head and per family, thus-

Per Head per annum

Per Family of Five per annum

\begin{tabular}{|c|c|}
\hline Working Classes. & Other Classes. \\
\hline EI Io 4 & 510 \\
\hline$£ 7$ II 8 & 92 \\
\hline
\end{tabular}

The figures are given as "very doubtful," but the writer adds, " in the present state of our statistical information I doubt whether we can get much better ones." He leaves the question of fairness " to the individual judgments " of his readers.

There is some further comment on this article and on the implications of its tables, in the Economic Journal, March, I899, "Is the English System of Taxation Fair ?" by Mr. C. P. Sangar. Three possible principles are indicated-Minimum Sacrifice, Equal Sacrifice, Proportional Sacrifice; and Mr. Sangar gives for comparison the chief results of two earlier calculations-thus-

I. LEONE LEVI.

Imperial and Public Burdens.

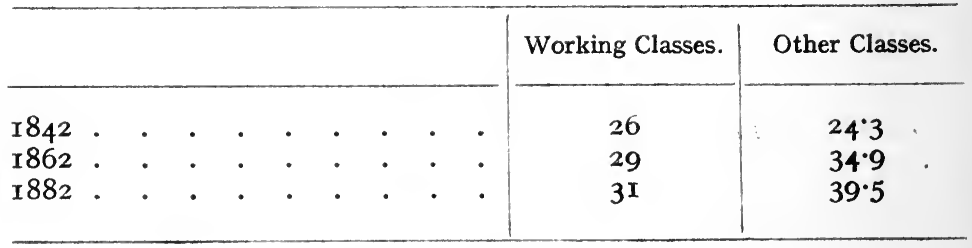

II. Dudley Baxter (I869).

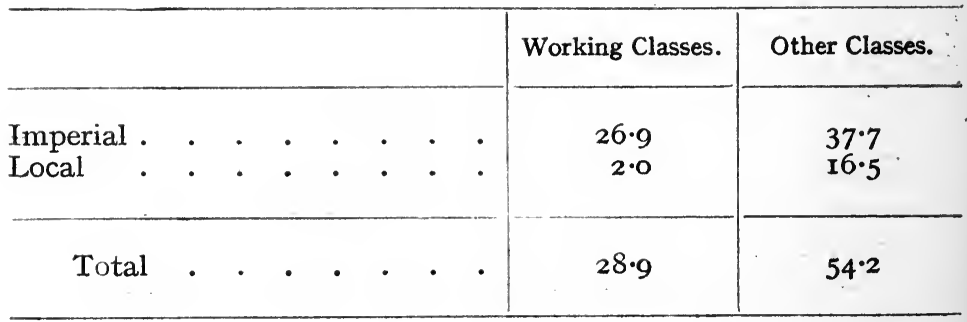

V.

The next example is in the form of a comparison between the amount of taxes per pound of income paidi by a labourer 
and a farmer respectively. It occurred in an article headed "The Labourer's Income Tax," by "A Country Parson," in the Daily Nerws, I9I2 (I have omitted to preserve the exact date, in cutting out the article). The cases cited are of individuals well known to the writer. The labourer " earns a steady I5s. a week. As a rule he has two pints of beer a day, sometimes a little more." The labourer himself considers two gallons a week a fairly correct average for the year, and he has about "eight half-ounces" of tobacco a week. His wife buys about six pounds of sugar, one pound of tea, one pound either of raisins or of currants, per week. On this basis the following computation of the taxes he pays is made out.

FARM LABOURER.

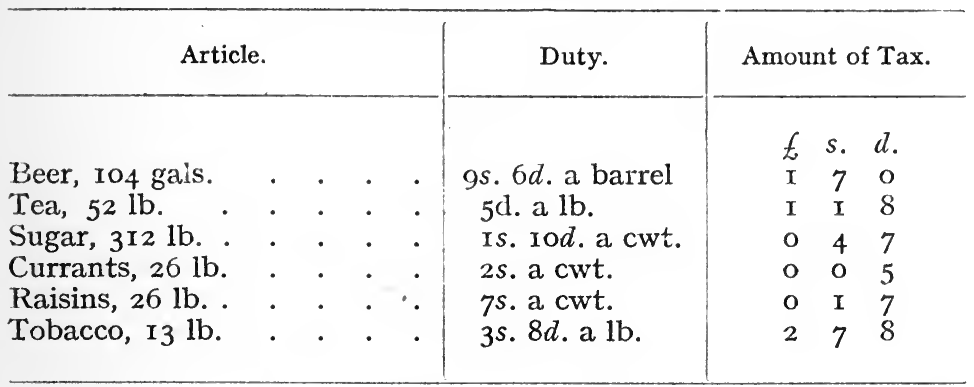

Total Taxes paid on an income of $£ 39$ per annum

$£ 5 \quad 2 \quad$ II

"The labourer's contribution is ... more than an eighth of his income. It is more than the equivalent of an incometax of half-a-crown in the pound."

(Note.-The duty on "manufactured tobacco" varies from 4 s. $8 d$. to 5 s." $4 d$. per $1 \mathrm{lb}$.)

The farmerIrents 400 acres, and his income " is only guesswork." It is "put at $£ 400$ per year, with the note "I do not fancy that he is assessed any higher." Further, "He keeps a motor and uses two gallons of spirit a week. He tells me a gallon of whisky lasts him four weeks; he has a barrel of beer a month."

From this we get the calculation on the next page.

" He pays . . . less than one-twelfth, or at the rate of under Is. $8 d$. in the pound."

The writer quite properly takes little notice of the fact that the labourer "could save $£ 3$ I4s. of the amount," i.e. by being a teetotaller and a vegetarian. If this argument is to be used 
FARUER.

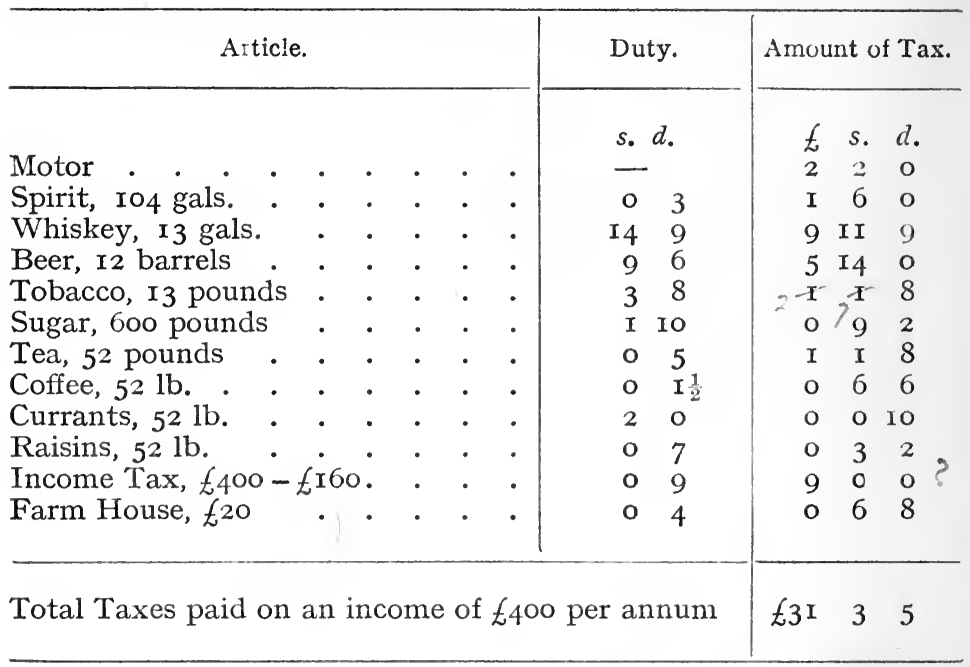

at all, it should be carried further. Why should the labourer and his wife drink tea? For tea is no more necessary for efficiency than beer or tobacco. Nor, in fact, are raisins or currants essential things. Mankind existed for ages without them. A dietary of bread, oats, potatoes, greens, pulse, and water, would no doubt be sufficient for full health and vigour. Why should not the labourer fall back on some such hygienic scale? The obvious answer is, that he is neither a simple working-machine nor a simple beast of burden, but a human being and a citizen.

* By eliminating beer, whisky, and tobacco, we should get a different ratio of taxes. It comes, in this case, to about $\frac{1}{28}$ of income for the labourer, and about $\frac{1}{27}$ of income for the farmer : a close equivalence that will please all who think the argument for such exclusion a valid one. The elimination of tea would make a slight further change. Then we might ask, what about the motor? In what sense is it, or is it not, a necessity?

There is, in actual life, a real scale of necessities, in each individual expenditure. But the scale is individual. There is no common scale that can be generally applied. This is one of the difficulties that make attempts at fixing the proportions of taxes paid by different people, so unsatisfactory in their actual significance. A certain expenditure being assumed, the amount of tax paid can with some accuracy be reckoned. But the expenditure of $£$ IOO or $£ I, 000$ is not always distributed among the same items, or in the same proportions. The inquiries 
are interesting, but the results are not safe bases for general inferences. In these two cases alone, there might easily be living in the same village other labourers with a wage of I5s., a week, B, C, D, and so forth, whose expenditure differed from that of the labourer cited, in these ways-

$B$ does not smoke.

$\mathrm{C}$ is a teetotaller.

$\mathrm{D}$ is a non-smoker and teetotaller.

E smokes, drinks beer, but never drinks (or buys) tea.

$\mathrm{F}$ does not smoke, or drink beer, or drink tea.

G Smokes, but does not drink beer or tea.

All these men will pay different fractions of their income in taxes. If we introduce spirits, we can nearly double the number of permutations. When, in the case of the farmer, we introduce spirits (for drinking) and the motor, as variable items in the expenditure of farmers with incomes of $£ 400$ per annum, we shall have about twenty differently-taxed farmers, each of whom can be paired-off for comparison with each of the labourers B, C, D, E, F, G, as well as with the original labourer A. It is plain that we can select a pair to prove that the farmer is harder hit than the labourer, or vice versâ. But, until we can agree upon representative tables of expenditure for men of each class, we can get no satisfactory results.

The obvious suggestion of an average offers itself. But averages are very unsatisfactory in things that are intensely personal and individual. Some plan is wanted that will retain and show the individual records of amounts paid, while placing them for comparison with the individual records of other individual cases in other classes of individuals, whether these be people of other social grades, or of different occupations, or simply people with different incomes.

Thus we might take the labourers A, B, C, D, E, F, G, just mentioned, and work out the poundage or percentage of total taxes paid, in each case. The same could be done for town labourers, for artizans, for people of any number of groups. If we take our series from A to $Z$, or nearly (so as to include 20 to 25 individuals in each series), all paying different poundages, we shall not need to trouble about the fact that there are more labourers of the A type than of the D or F type; but if we take a smaller series, such as A to $G$, we must from other sources reckon how many A's should be counted in with one $F$. These could be plotted out in a curve, and other curves could be plotted in like manner for other groups. We should then have before us series contrasted with series, the average of each series lying side by side with the average of other series, and the extremes and range of each showing at a glance for comparison. From a large number of such eurves we could make such generalisations 
as the following, generalisations, however, that should be read and considered together with the curves themselves-

Rural Labourers with wages $14 s$. to $\mathrm{I} 7 \mathrm{~s}$. per week, pay gross
taxes varying $\cdot \cdot \cdot \cdot \cdot \cdot \cdot \cdot \cdot \cdot \cdot \cdot$ from

Rural Labourers with wages $14 s$. to $\mathrm{I} 7 \mathrm{~s}$. per week, pay gross
taxes varying $\cdot \cdot \cdot \cdot \cdot \cdot \cdot \cdot \cdot \cdot \cdot \cdot$ from

Pence

in the

$t$ and averaging. . $y$

and so with other groups.

But as for pure taxes, the difficulties are so great, once we get away from the Income Tax and Estate Duties, as to make the task nearly hopeless.

\section{VI.}

Mr. Chiozza Money, in an article of April, I913, makes a computation which he gathers into two tabular statements, the second being the last column of the table as given here, and the first, the other columns.

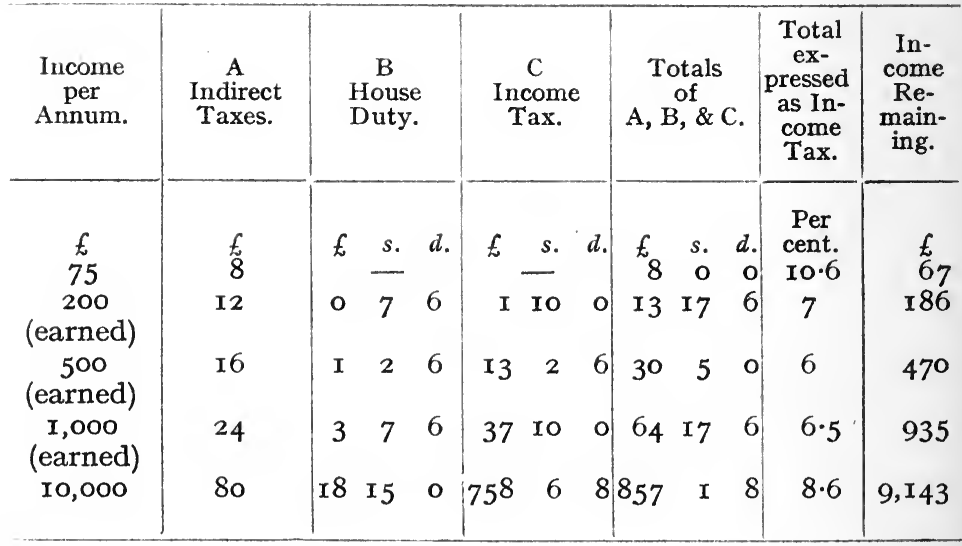

His first case is of " a family with 30s. a week," which would be $£ 78$ per year, but is set down at $£ 75$ to make some allowance for unemployment-probably an insufficient allowance in the majority of cases. The $£ 8$ of indirect taxation is arrived at by dividing the $£ 72,000,000$ of customs and excise duties by the number of families in the United Kingdom-9,000,000. "A teetotal, non-smoking family would, however, pay much less."

The $£ 200 \mathrm{man}$ is assumed to live in a $£ 30$ house, and his indirect taxes are reckoned at $I \frac{1}{2}$ times the average for the country. The indirect taxes of the man with an income of $£ 500$ are put at twice the average, $£ I 6$, and those of the man with $£ I, 000$ a 
year at four times the average. A house rented at $£ 45$ is assumed to be appropriate for an income of $£ 500$, and a house at $£ 90$ for an income of $£ \mathrm{I}, 000$. These rentals are rather low, if anything, for London, but are probably fair approximations for the whole country. The man with $f 10,000$ a year is credited with two houses, each of an annual value of $£ 250$, and his indirect taxes are put (with a view to the consumption of taxed commodities by his servants) at ten times the average

Stamp duties are omitted throughout.

Mr. Money's conclusion is that "the rate of taxation does not diminish in any sensible degree the enjoyment to be got out of a big income by its owner."

\section{VII.}

There are several tables given in " Some Notes on the Incidence of Taxation on the Working Class Family," by F. W. Kolthammer, M.A. ("Ratan Tata Foundation," published through the London School of Economics, IgI3). The writer's conclusions are summed up in seven "General Findings," of which the most striking is that food taxation in this country is regressive. The smaller incomes pay a disproportionately large percentage. The working-class family is held to pay $6 d$. per week in indirect taxes.

The following is a selection from Table $\mathrm{X}$. Taxation is shown as a percentage of income. In the table as given, there are thirtyone incomes, ranging from I8s. to $£ 5$ per week.

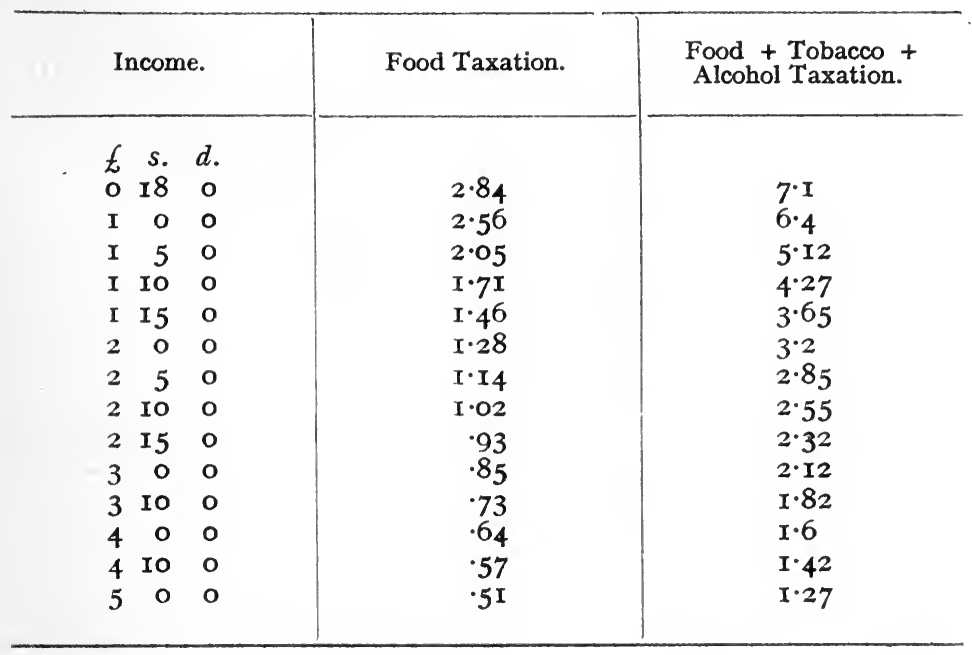


The relatively lighter indirect taxation of higher incomes comes out very markedly in this table, offering a confirmation of Mr. Money's findings.

The basis of the figures is stated in the pamphlet, but it cannot be given fairly except at some length. The curious must turn for it to the pamphlet itself. 


\section{Appendix III.}

\section{BIBLIOGRAPHIA.}

The references given in Chapter I (Appendix) and in Chapter II make a bibliography of over a hundred books, but many of them are not books solely or chiefly dealing with taxation.

The references that follow are of the nature of a short bibliography of bibliographies on taxation, rather than an attempt at a new bibliographical list. The reader who wants guidance to a few standard books can usually get it in any modern textbook on the subject. The student who wants a full bibliography for reference needs more than can be offered at the end of a work such as this.

For English readers, the lists given in two of the following works are so complete, that with their accessibility they are sufficient for all but exceptional purposes. The two works are Seligman's "Incidence" (3rd Edition, I9ro) and Bastable's "Public Finance." In the former work, the bibliography is given as such. It is chronologically arranged, and it includes over 500 references.

The works cited in Bastable's "Public Finance" are given as a list in the first edition (I892), but in the second (I895) and third (Ig03) editions they are mentioned only in the text, and must be traced by using the index. The range, however, is very wide.

Part I refers to general bibliographies on taxation.

Part II gives bibliographies of current issues.

\section{PART I. GENERAL BIBLIOGRAPHIES.}

Stammhammer, J.

" Bibliographie der Finanzwissenschaft," I903. Jena : Gustav Fischer. A very full list. Arrangement, chronological, in sections. Of these, Steuerlehre (p. 295 et seq.) and Steuergrundsätze '(p. 293 et seq.) refer more , particularly to the subject of this book. i

By far the completest bibliography of taxation /yet issued. 


\section{Seligman, E. R. A.}

"The Shifting and Incidence of Taxation," 3rd edition, published by the author, New York, I9Io.

The appended bibliography gives over 500 works, arranged as-

(I) Signed works before 1776 .

(2) Anonymous works before 1776 .

(3) Works since 1776 .

An edition is issued in French, "Thêorie . . . de l'Impôt" (I9I0) with the bibliography in full (Br. Mus. 08227, c. I5).

There are full bibliographies also in Professor Seligman's "Income Tax" (34 pp.), and in his issued works generally.

Bastable, Prof. C. F.

"Public Finance," Macmillan, I903 (3rd edition, enlarged). The references are in the text, and in footnotes, but there is a good index.

\section{"Standard Books."}

Nelson, I9Io.

Vol. I. pp. 603 to 606 gives about I20 works, chiefly modern.

\section{"The Best Books."}

Sonnenschein, First Ed., I887. Re-issued I89I, I896, I901, 1903. About 40-50 works, pp. 236-237 and p. 218. There are brief directing notes. ("Sonnenschein" is now G. Allen \& Co.)

\section{" The Readers' Guide."}

Sonnenschein, I895. A Supplement to "The Best Books." Under "Public Finance and Taxation" about 40 works lare cited, with notes (pp. I76-I78).

\section{Gebe-Stiftung.}

"Katalog der Bibliothek der Gebe-Stiftung zu Dresden," I90o. Band I. Unterabtheilung I. Nationalökonomie und Finanzwissenschaft, 224 pages, including a "Book and Author," Index.

\section{Georg Hanssen (Göttingen).}

Katalog Nationalœkonomie, J. Baer \& Co., Frankfurt, IgII.

Part XII. Finanzwissenschaft, Steuer und Zollwesen, pp. 259-306.

\section{McCulloch, J. R.}

"The Literature of Political Economy," I845, Longmans. Chapter XIX. "Revenue and Finance," pp. 3I8-349, gives a good list of works issued between I679 and I845. 
Coquelin et Guillaumin.

"Dictionnaire de l'Economie Politique," I852 (re-issued in 1874), 2 vols. Article, "Impôt." A bibliography of about 200 books and pamphlets, pp. 9I0-9I4 (Br. Mus. 8207, S. I).

Cossa, L. (Dyer, tr.).

"Introduction to the Study of Political Economy" (a translation of Cossa's "Guida alla Studio dell' Economia Politica," 1876. Translation, I893). The "Historical Part," pp. II3549 , has references at the end of every section, making altogether a full bibliography. The "Taxation" references can be traced by the Index. They do not form a large part of the book.

\section{Schönberg, Gustav von.}

["Handbuch der Politischen Ekonomie," Tübingen. Fourth (and last) edition, I897. This work was constantly revised until the death of the editor. Vol. 3 deals with Finance. The many references are given at the heads of the chapters and in small type paragraphs. There is a good index.

Gide et Rist.

"Histoire des Doctrines Economiques," by Chas. Gide and Chas. Rist. Paris, I909. There are many references to books, chiefly in the form of footnotes, but those referring to Taxation cannot easily be traced, as there is no index except one of proper names.

Haney, Dr. L. H.

"History of Economic Thought," Macmillan, IgII. There is an Index of Names, and a General Index, by which a good many references can be traced in the general account.

Plehn, Dr. C. C.

"Introduction to Public Finance," Macmillan, 3rd Edition, enlarged, Igog.

A bibliography of about 40 works is given on pp. $466-468$.

\section{Wagner, A.}

"Finanzwissenschaft," Leipzig und Heidelberg, and ed. 1877, 3rd ed. I883. 3 vols.

The references are given throughout the volumes in paragraphs set in smaller type. There is no index.

Conrad, J.

“ Grundriss der Politischen Ekonomie," Pt. III. Finanzwissenschaft. With a bibliography of over 200 works, given at the heads of the chapters and sections. 


\section{Eheberg, K. von.}

"Finanzwissenschaft." Twelfth /(enlarged) edition, frgr2. Many works are cited at the ends of the chapters, and there is a good general index.

\section{Girardin.}

"L'Economie Politique et l'Impôt." [With a list lof nearly eighty works.

Grice, J. W.

"National and Local Finance," P. S. King \& Son. rgro. Seven pages of bibliography, including official papers and general works issued in England, France, Belgium and Prussia, dealing chiefly with the relations between national and local finance.

\section{"What to Read on Social and Economic Subjects."}

P. S. King \& Son. Fabian Society. About 25 works, all modern, and including Governmental publications.

\section{Lorenz, Otto.}

"Catalogue Général de la Libraire Française."

Issues for I840-I865, et seq., as far as Igo6-Igog.

The $1840-1865$ issue (6 vols.) is under Authors' Names.

The I840-I875 issue is under Subjects. It gives about I50 books under "Impôt."

The last subject index ends with I905 (I900-I905). It gives over Ioo additional books, and there are about 200 in three intervening subject-volumes; about 450 volumes in all $(\mathrm{Br}$. Mus. Reference Shelf 2036).

On the same shelves are Barbier's " Dictionnaire des Ouvrages Anonymes," Halkett and Laing's " Dictionary of Anonymous and Pseudonymous Literature" (2035) and similar compilations.

\section{Léon Say et J. Chailley (Ed.).}

"Nouveau Dictionnaire de l'Economie Politique," I892. Vol. II. pp. 64-66. Nearly three columns of bibliography, at the end of the article "Impôt." The works are classified, but on a plan more interesting than helpful.

\section{Parliamentary Papers. A Catalogue.}

Pub. P. S. King \& Son.

I80I-I900, with a few of earlier date.

rgoI-Igro, Supplement. "Taxation," "Local Taxation," "Income Tax." 


\section{A. P. C. Griffin.}

Select List of Works Relating to Taxation of Inheritances and of Incomes United States and some Foreign Countries.

Washington. Library of Congress. I907.

H. H. B. Meyer.

Additional References (to above). Washington. Library of Congress. IgII.

Fortescue. Subject Index. British Museum.

PART II. BIBLIOGRAPHIES OF CURRENT ISSUES "Bibliographie der Socialwissenschaften"; "Bibliography of Social Science."

Editors, Dr. H. Beck, Berlin, Dr. Chas. Kinzbrunner, London. Published in six editions, in the German, French, English, Italian, Russian and Hungarian languages, as a monthly journal (beginning in January, I905). The "parent" edition is still issuing-" Bibliographie der Socialwissenschaften," Dresden, O. V. Boehmert, Ed. Dr. H. Beck. Section IX in each monthly part is a bibliography of Public Finance, and sub-section 2 deals with Taxation.

Until August, I9I2, the University of Chicago and the Cambridge University issued an English edition, which has now ceased to appear.

Works not in English, French or German have their titles translated into German.

"Bibliographia Economica Universalis."

Originally issued 5 to 7 times a year, beginning with I9O2. Bruxelles : Institut International de Bibliographie. Still issuing.

The plan is similar to that of the "Bibliography of Social Science." There are now monthly issues, and Public Finance appears under the classification number 336. Taxation comes under 336.2 .

The original editors were Jules Mandello and Ervin Szabo, but there have been several additions and changes.

Poole's Index to Periodical Literature.

Under "Tax," "Taxes," and "Taxation." For articles in periodicals. Vol. I. I8I5-I899. (In two parts or ${ }_{5}$ volumes. There is an "abridged edition in one volume.)

Supplements.?

Ist. I882-I887.

2nd. $I 887-I 892$.

3rd. I892-I896,

4 th. [I896-I902.

5th. I902-I907. 
Reader's Guide to Periodical Literature. H. W. Wilson Co., Minneapolis.

Vol. I. Ig00-I904.

Vol. II. Ig05-Ig09.

The Times Index. 


\section{INDEX}

(Q. signifies a quotation on the page marked.)

Académie Française, Definition of Impot, Q. 263

Adams, H. S., Q. $1_{4} 6$ Definition of " Tax," Q. 255

Alternatives to Economy as a First Principle, 233

Altman, Dr., Q. 148

Analogy of the Buttercup, ro of the Oxen, 176

of the Vassal and the Overlord, I72

Anonymous, Q. II 4

Âpastamba, Q. 49

Arbitrariness of Progressive Scales, 189

Aristotle, Q. 57

Assemblée Nationale, Definition of Impôt, Q. 260

Assessing Payments, Three Methods, 39

Atkinson, Definition of Taxation, Q. 25I

Austin, on Equity, Q. 165, et seq.

Autocracy, Democracy and Taxation, 2 II

BAcon, Q. 60

Bastable, Prof., Q. I4I

Bibliography, 286

Definition of Tax, 35, Q. 253

on Direct and Indirect Taxes, 202

on Divisions of Public Revenue, on " Optional " Taxes, Q. 34

Productive Expenditure, 20

on Public Buildings, 22

on Productivity, Q. 154

on Revenue and Taxes, 4

on Taxes paid by Persons, I2

Baudeau, Definition of Revenue, Q. 257

Baxter, D., 278

Calculations of Taxes, Q. 126
Beaulieu, Leroy, on Incorrect Definitions, 269

Definition of Impôt, $26_{4}$

Beaumont, Moreau de, Q. 88

Scale of Taxes, 90

Bielfeld, and A. Smith, 88

Belloc, Hilare, on Property, 205

Belot et Bertrand, "Rights of Man," I05

Benefit Theory, 59

Bentham, J., Q. 102

Definition of Tax, Q. 250

Benthamism, Prof. Edgeworth on, 195

Berthelot, Q. I27

Definition of Impôt, Q. 263

"Best Books," Bibliography, 286

Biblical References, 48

Bibliographies, 285

Current Literature, 289

Bibliographie der Staatswissenschaften, 289

Bibliographia Economica Universalis, 289

Bielfeld, Q. 79

Bielfeld, Beaumont, and A. Smith, 88

Bishop of Llandaff, on Progressive Taxes, 123

Blackstone, Definition of Tax, Q. 250

Blank Period, 56

Bodin, O. 59

Boisguillebert, Q. 68

Borght, van der, Definition of Steuer, Q. 266

Definition of Gebiühren, Q. 268

Borrowings, 6,7

Boucard et Jèze, Q. I 42

Definition of Impott, Q. 264

on "Optional "Taxes, Q. 34

Divisions of Public Revenue, 3

Brooke, Rajah, I4

Buchanan, Q. 108

Buckingham, J. S., Q. I2I

Budgets (Family) and Taxes, 270 
Budget of 1909, 222

Bullock, Prof., on Direct and Indirect Taxes, 202

Burke, Q. 100

"Buttercup" Analogy, ro

CaIllie, W. S., on Post Office Revenue, $3 \mathrm{I}$

Calculations of Taxes, 270

Cannan, Prof., Q. I39, v. vi.

Definition of Tax, Q. 255

on Distribution of Wealth, Q. I69

on Distribution of Wealth, Q. I8I

on Equity, Q. I62

on Justice, Q. 163

on Legitimate Expectations, $2 \mathrm{I} 4$

on Legitimate Expectations, Q. 217

Productivity, Q. 158

on Profits, Q. 17

on Rates, Q. 26

"Canon of Poetry," 58

Carver, Q. ${ }^{4} 42$

Caution in Taxation, 227

Certainty, A. Smith on, Q. I54

Certainty and Equity, 59

Chaillez, Say et, Bibliography, 288

Chambers' Encyclopædia, Definition of Tax, Q. 254

Dictionary, Definition of Task, Q. 249

Channing, Dr., Q. II3

Chapman, Prof., Q. ${ }^{4} 8$

Characteristic Principle of Taxation, 242

Charges, Scales of, 27

Chen Huan-Chang, Dr., Definition of Tax, Q. 267

on Confucius, Q. 58

Chesterton, G. K., on Property, 205

Chinese Definitions of Tax, Q. 267

Chiozza Money, Calculations of Taxes, 282

Cicero, Q. 53

Citizenship and Taxation, 207

Clamageran, Definition of Impôt, Q. 262

Classification of Principles of Taxation, 220

Cliffe, Leslie, Q. I 27

Codex Justinianus, Q. 58

Cohn, Q. 134

Definition of Steuer, Q. 266

Colson, Q. I33

Definition of Impot, Q. $26_{4}$
Commodity Taxes, 235

A. Young on, 76

Communal and Individual Spending, S. Webb on, Preface

Condorcet, Q. ro6

Definition of Impot, Q. 260

Confucius, Q. 58

Conrad, Prof., Q. I40

Bibliography, 287

Divisions of Public Revenue, 3

on Local Finance, 4

Definition of Gebühren, Q. 267

Definition of Steuer, Q. 266

Contribuzioni, Definition, Q. 268

Coquelin et Guillaumin, Bibliography, 287

Corn Taxes, Gide on, I7I, 215

Correct Definition of Tax, First, 150

Cossa, Bibliography, 287

Definition of Tax, Q. 268

" Country Parson," Calculations of Taxes, 228

Courtney, Lord, on Post Office Revenue, 3 I

Crabb on Economy, Q. 177

Customs and Subsidies, Milles' Definition, Q. 257

"Darly News," Calculations of Taxes, 278

Daire, E., 78

Definition of Revenue (Physiocrats), Q. 258

Dazi, Definition, Q. 268

"Death Duties," 193

Decker, Q. 69

Scale of Taxes, $7 \mathrm{I}$

Dutch Poll Tax, 70

De Corpore Politico, Q. 64

Definitions, 246-269

of Tax, Taxes and Taxation, 248

of Fee, Revenue and Rate, 257

of Impot, 258

of Stewer, 264

of Dazi, Gebühr, Imposta, Tas-

sa, Contribuzione, 267-269

Incorrect, 269

of Profits, 30

of Rate, 30

of Tax and Price, 43

of Taxes, Pure Taxes, Quasi-

Taxes, and Prices, 29

of Tax, First Correct, 150

of Tax related to Principle of

Taxation, I70, I75

of Tax, Prof. Bastable, Q. 35

Prof. Edgeworth, Q. 35 
Definitions, Sir R. Giffen, Q. 32

Sir L. Gomme, Q. 32

Prof. Gonner, Q. 32, 36

Sir E. W. Hamilton, Q. 32

Prof. Sidgwick, Q. 35

Definitions, Review of, 247

Degressive and other Scales, 186

Demands of Economy in Taxation, 245

Democracy, Autocracy and Taxation, 2 I I

De Parieu, Q. 122

De Quincey, on Profits, Q. I 5

Detail de la France, Q. 68

Diagram of Taxes and Prices, $4 \mathrm{I}$

of Economy and Public Utility, $23 I$

Diagrams of Progressive Scales, I9I

Dictionnaire de l'Academie francaise, Definition of Impot, Q. 263

Diminishing Utility, I87

Utility, 234

Utility and Income, I88

Dime Royale, Q. 68, 69

Dionysius Halicarnassus, Q. 54

Direct and Indirect Taxes, Figures, 202

Bastable on, 202

Lowe on, 201

Disraeli on, 20 I

Disraeli on Direct and Indirect Taxes, 20I

Distribution of Wealth, Prof. Cannan on, Q. I69, Q. I8I

Prof. Marshall on, Q. I8I

Distribution of Wealth and Taxation, I82

Divisions of Public Revenue, 3

Dualism in Taxation, 242

Dudley Baxter, Calculations of Taxes, 278

Dupont de Nemours, Q. 85

Definition of Impot, Q. 259

Duty on Tea, 274

EARLy Notions of Taxation, 47

Economic Theory and Practical Taxing, 203

Economists and Taxes, S. Webb on, Preface

Economy, Crabb on, Q. I77

Demands of, 245

and Equity, 244

Implications of, I79, 197

Individual and General, I 7 I

Economy and Justice, with Price and $T_{\text {ax, }}, 176$

and Justice, 198
Economy, Original Meaning, I77

as a Principle of Taxation, $15^{8}$, I6I, I7I

Principle of, Classified, 215

as Sole Principle, 213

and Public Advantage, 230

Diagram of, $23 I$

Rules of, I79

its Six Points, 214

Verri on, 75

Wicksteed on, Q. I78

Edgeworth, Prof., Q. I37

on Benthamism, I95

Definition of Tax, Q. 35

on Minimum Sacrifice, 195

on Post Office Profits, Q. 35

Editors of Voltaire, Q. 87

Effects of Taxes, I85

Eheberg, Q. I4I

Bibliography, 288

Ely, Professor, Definition of Taxation, Q. $25 \mathrm{I}$

Emotion and Reason, 207, 217

Encyclopédie, La Grande, Definition of Impót, Q. 263

Encyclopedic Dictionary, Definition of Tax, Q. 248

Definition of Task, Q. 249

"English" Period, 96

Equal Incomes and Taxation, 209

Equality, Prof. Nicholson on, I 55

Equity and Economy, 244

Equity, Austin on, Q. I65

Prof. Cannan on, Q. I62

Why not Primary in Taxation, I 52

as a Principle of Taxation, 162, I64

Estate Duties, Income Tax and Revenue: Figures, 200

Expediencies of Taxation, 213, 216

Expediency, Political, 232

Expenditure, I9

and Taxation, Preface

Factum de la France, Q. 68

Family Budgets and Taxes, 270

Fee, Definition, Q. 256

Ferguson, A. Q. 105

"Fermiers" (Quesnay), Q. 76

Fetter, Prof., Q. I45

Definition of Taxation, Q. 254

Finance, Local and National, 4

Flora, Definition of Tassa, Q. 269

Flügel, Definition of Gebühr, $Q$. 267

Flux, Prof., Definition of Tax $Q$. 254 
Flaix, Fournier de, Definition of Impot, Q. 263

Formative Period, 59

Fortescue, Bibliography, 289

Fourbonnais, Definition of Revenue, Q. 257

Fournier de Flaix, Definition of Impôt, Q. 263

Foxwell, Prof., Introduction to Menger, II 9

French Corn Duties, Gide on, I7 I , 2 I 5

GALE, S., Q. IO2

Garnier, Definition of Impôt, Q. 262

Gebe-Stiftung, Bibliography, 286

Gebühr, Definitions, Q. 267

George, Henry, O. I 28, 125

Gesschen, Definition of Steuer, Q. 266

Gide et Rist, Bibliography, 287

Gide, on Corn Taxes, I7I, 215 on Profits, Q. I5

Giffen, Sir R., on Taxation, Q. 34 Definition of Tax, Q. 32, 253 , 256

on Post Office Revenue, 3I

Gillies, Dr., Q. 57

Girardin, Bibliography, 288

Goldsmith's Library, 88

Gomme, Sir G. L., Definition of Tax, Q. 32

Definition of Taxation, Q. 253

on Post Office Profits, Q. 35

on Post Office Revenue, 3I

Gonner, Prof., Definition of Taxation, Q. 32

Definition of Tax, Q. 252

on Post Office Revenue, $3 \mathrm{I}$

on Post Office Profits, Q. 36

Goods and Services, 205

Graduated and Proportional Taxes, 244

Gradualness in Taxation, 228, 233 , 244

"Grains" (Quesnay), Q. 77

Grande Enclyclopédie, Definition of Impôt, Q. 263

"Greatest Happiness" and Prof. Edgeworth, 195

Greece and Rome, 52

Grice, Dr., Bibliography, 288

Griffin, Bibliography, 289

Guillaumin, Coquelin et, Bibliography, 287

Guyot, Definition of Impót, Q. 263

HADley, Prof., Q. 135

Definition of Tax, Q. 252
Halicarnassus, Q. 54

Hamilton, Sir E. W., Definition of Tax, Q. 32, 253

on Post Office Revenue, 3I

Haney, Dr., Bibliography, 287

Hannsen, G., Bibliography, 286

Harington, James, Q. 65

Definition of Tax, Q. 250

Held, Q. I 27

Herodotus, Q. 53

Hobbes, Q. 62

Definition of Customs and Tributes, Q. 249, Q. 250

Hobson, J. A., Q. I45

Definition of Tax, Q. 254

Use of Economic Terms, 9

Hume, Q. 7 I

Humour in Economics, v.-vii.

IMPLICATIONS of Economy, 179, 197

Import Duties, Dr. Johnson on, Q. I64, 207

Imposta, Definitions, Q. 268, 269

Impôt, Definitions, Q. 259

Incorrect Definitions, Q. 269

Incidence, vii.

Income as a Basis for Taxation, 209 and Diminishing Utility, I 88 and Property, 200, 204, 205 Significance of, 200, 205

Tax, Proportion to Revenue, 199, 200

Tax, Dr. Slater on, Q. 198

Tax, Steps of Scales, 192

Tax, Yield since 1844 , 199

Incomes, Equal, and Taxation, 209

Indirect and Direct Taxes, Prof. Bullock on, 202

Indirect and Direct Taxes : Figures, 202

Indirect Taxes, J. S. Mill on, Q. 33

Individual and Communal Spending, S. Webb on, Preface

Inequality of Taxes, Jevons on, $Q$. 219

Interests, Private and Public, 218

Jevons, Stanley, Q. I25 Calculations of Taxes, 275 on the Match Tax, 275 on Taxation in 1869, Q. 219

Jèze, Boucard et, $Q$. 142 Definition of Impot, Q.264 Johnson, Dr., on Import Duties, Q. I64, 207

Justi, Q. 74

Justice, Prof. Cannan on, Q. 163 and Economy, I98 
Justice and Economy with Price and Tax, 175

as a Principle of Taxation, 162, 169

Shelley's Definition, Q. I68

in Taxation, 223

Why not Primary in Taxation, r 52

KAMES, Lord, Q. 76, 92

Kameralists and Mercantilists, 59

Kolthammer, Calculations of Taxes, 283

K'ung Ying-ta, Q. 58

LA Mothe de Vayer, Q. 6I

La Rivière, Mercier de, Q. 84 and Pesselier, 80

Laws of Manu, Q. 50

Definition of Tax, Q. 267

"Leave Them As You Find Them," 59, Q. I8I, I83

Legitimate Expectations, 214, Q. 217

Leone Levi, Calculations of Taxes, 278

Leroy-Boileau, Q. 143

Definition of Impot, Q. 264

on Incorrect Definitions, 269

Leslie Cliffe, Q. 127

"L'Esprit des Lois," Q. 72

Levi, Leone, Calculations of Taxes, 228

"Leviathan," Q. 62

Definition of Customs and Tributes, Q. 249

Lî Kî, Q. 5 I

Livy, Q. 53

Llandaff, Bishop of, on Progressive Taxes, 123

Local and National Finance, 4

Locke, Q. 67

on Taxes and Land, 74

Lorenz, Bibliography, 288

Lowe, R., Direct and Indirect Taxes, 20I

Projected Match Tax, 275

Lu Chih, Q. $5^{8}$

Mackay, T., on Post Office Revenue, $3 \mathrm{I}$

Macnab, Q. 107

Man, Emotional and Rational, 207, 217

Manu, Laws of, Q. 50

Manu, Definition of Tax, Q. 267

Marginal Utility, 234
Marshall, Prof., on Distribution of Wealth, Q. 18I

and Individualist Economics, II9

on Post Office Profits, 36

on Profits, Q. 15

Maxims of A. Smith, Beaumont and Bielfeld, 88

T. Rogers on, Q. I60

Unscientific, 153

“Maximes Générales," Q. 77

Massie, Calculations of Taxes, 271

Mayr, Definition of Steuer, Q. 266

McCulloch, Q. II 7

Bibliography, 286

Definition of Tax, Q. $25^{\circ}$

"Memoranda on Imperial and Local Taxation" (Bluebook C. 9528, 1900), 3I et seq., 2I4, 2I7

Menier, Q. 128

Definition of Impott, Q. 263

Mercier de la Rivière, Q. 84

Definition of Impot, Q. 260

Mercantilists and Kameralists, 59

Meyer, Bibliography, 289

Meyer, E., on Local Finance, 4

Mill, James, Q. II3

on "Leave Them as You Find Them," Q. I8I

Mill, J. S., Q. II9

his "Political Economy," I I9 on Indirect Taxes, Q. 33

Milles, Definition of Customs and Subsidies, Q. 257

Minimum Sacrifice, 109, II9

Prof. Edgeworth on, 198

Minor Rules of Taxation, 225

Mirabeau, Q. 80

Definition of Impót and Contribution, Q. 259

Definition of Impot, Q. 260

Mixed Taxes, 7

Moderns, The, I 30

Money, Chiozza, Calculations of Taxes, 282

Montchrétien, Q. 6r

Montesquieu, Q. 72 and Pollux, 54

Definition of Revenue, Q. 258

Moreau de Beaumont, Q. 88

Movements in Economic Theory and in Budgets, 203, et seq.

Multiplicity Doctrine, 76 , Ir9

Murray, Sir James, Definition of Fee, Q. 256

Definition of Rate, Q. 258

Definition of Tax, Q. 248

Definition of Taxation, Q. 249 
Natronal and Local Finance, 4

Nausinicus, 55

"Necessary Evil" View of Taxes, 124

S. Webb on, Preface, I 24

Necessity of Taxes, S. Webb on, Preface

Necker, Q. I Ior

Need and Distribution, I69

Negative Taxes, 27

Nemours, Dupont de, Q. 85

Definition of Impot, Q. 259

Nicholson, Prof., Definition of Tax,

Q. 252

Definition of Taxation, Q. 253

on Equality of Taxation, I55

Nitti, $Q$. I 40

Definition of Tassa and Imposta, Q. 268

Noble, on Direct and Indirect

Taxes, 20I

"National Finance," 20I

" Ocenana," Q. 65

Definition of Tax, Q. 250

"Old Tax no Tax," 219, 227

"Optional" Taxes, 33

Orr, J., Q. I49

Overlord and Vassal, Analogy of, I72

Oxen, Analogy of, 176

Parallel Movement in Economic Theory and Practical Taxes, 203, et seq.

Parieu, de, Q. 122

Classification of Tax Terms, Q. 262

Definition of Impot, Q. 262

Parliamentary Papers, Bibliography, 288

Parnell, Sir H., Q. II3

Payment According to Need, 169

Pesselier, Q. 80

Petty, Q. 65

Physiocratic Definition of Revenue, Q. 258

Period, 74

Pinto, I., Q. 90

D. Stewart on, 76

Plato, Q. 53

Plehn, Prof., Bibliography, 287

Definitions of Tax, Fee, Rate,

Q. 254

Pliny, Q. 54

Political Expediency, 232

Rules of Taxation, 213, 216

Poll Tax, 70
Pollux, Q. 54

Poole's Index, 289

Post Office Charges, 23

Profits, 18, 37

Post Office Profits:-

Prof. Edgeworth on, 35

Sir G. L. Gomme on, 35

Prof. Gonner on, 36

Prof. Marshall on, 36

Post Office Revenue :-

W. S. Caillie on, 3I

Lord Courtney on, $3 I$

Sir R. Giffen on, 3I

Sir L. Gomme on, 3I

Prof. Gonner on, 3I

Sir E. W. Hamilton on, 3I

Price, Definition of, 29

Price and Tax, Definitions, 43

Price and Tax, 243

with Justice and Economy, 175

Principles of Taxation, Chief, 243

List of, I5I, 153

Classified, 220

and Definition of Tax, I70, I75

of Economy Classified, 215

Principles and Expediencies of

Taxation, 213

of Taxation, List of, $151, I_{53}$

of Taxation, in two Groups, I6I

Private and Public interests, 218

Procrustean Taxation, 194, 195, 2 II, 240

Procrustean, Proportional and Progressive Taxation, I94

"Productive," I9, 20 .

Productivity, 2 ro

Prof. Bastable on, Q. I54, 155

Prof: Cannan on, Q. 158

as a Principle of Taxation, 154, et seq.

"Produit net," 74

Profits, 6, 7

Prof. Cannan on, Q. I7

Definition, 30, Q. 15-18

De Quincey on, Q. 15

Gide on, Q. I5

Marshall on, Q. ${ }_{5}$

T. Rogers on, Q. 15

Walker on, Q. 15

Post Office, 18

and Rents, 17

or Taxes, 236

Progression and Proportionalism, 52, 56, 130, I59, I94

Progressive, Proportional and Pro-

L crustean Taxation, I94. 
Progressive Scales, 189, 190, 192, I93, I94.

Diagrams, I9I

Progressive Scales, Arbitrary, 189 and other Scales, 186

Taxes, Seligman on, 55, 123

Taxation, Ancient, 54

Property, State, 235

and Income, 200, 204, 205

Taxes, 206

Proportional and other Scales, 186

Proportional and Graduated Taxes, 244

Proportional, Progressive and Procrustean Taxation, I94

Proportionalism and Progression, $52,56,130,159$

as a Reform, 76

Proudhon, Definition of Impot, Q. 262

Public Advantage, 228, 230

Advantage, Diagram, 23I

Advantage and Taxation, 244 and Private Interests, 218

Revenue, Divisions, 3

Utility, I67

Pufendorf, Q. 66

Definition of Tributa, Q. 267

"Pure" Interest, I7

Pure Taxes, Definition, 29

Pure Taxes, 7, 8, 242

Puynode, Definition of Impot, Q. 261

Pseudo-Xenophon, Q. 53

Qualitative and Quantitative Values, 22I et seq.

Quantitative Values, 221

Quasi Taxes, v., 7,8

Definition, 29

Quesney, Q. 76

Definition of Impot, Q. 259

Quid pro quo, I9

\section{RATES, 5}

Prof. . Cannan on, Q. 26

Rate, Definition, 30

Rate, Sir J. Murray's Definition, Q. $25^{8}$

Rates and Taxes, 23

Rating-Charges, Methods, 27

Rau, Q. II 5

Raynal, Definition of Impot, Q. 260

Reader's Guide, Bibliography, 289

Real Income and Revenue, 22

Reason and Emotion, 207

Regressive and Other Scales, 186

Reid, H. L., Q. I37
Rent and Profits, 17

Revenue; Income Tax and Estate Duties: Figures, 200

Revenue and Real Income, 22

Revenue (Public), Divisions, 3

Revenue and Taxes, I, 4, 5

Table, $2 \mathrm{I}$

Revenue only, Taxation for, 183

"Reward" in Economics, 13

Ricardo, Q. IIO

Definition of Tax, Q. $25^{\circ}$

"Rights of Man," Q. IO5

Riquetti, Q. 80

Rist, Gide et, Bibliography, 287

Rivière, Mercier de la, Q. 80, Q. 84

Definition of Impott, Q. 260

Rogers, T., Q. 123

on Profits, Q. I5

on A. Smith's Maxims, Q. I60

Rome, 52

Roscher, Definition of Steuer, Q. 265

Ross, E. A., Q. I34

Definition of Tax, Q. $25 \mathrm{I}$

Rossi, Definition of Impot, Q. 26I

Rousseau, Q. 78

SACRED Laws of the Aryas, Q. 49

Sacrifice, Minimum, Prof. Edgeworth on, 195

Sargant, Q. 123

Say, J. B., Q. I07

Definition of Imp6t, Q. 26I

Say, L., et Chailly, Bibliography, 288

Scale of Taxes, Beaumont, 90

Scales, Progressive, 189, 190, 192, 193, I94

Diagrams, I9I

Schäffle, Q. I 35

Schönberg, Bibliography, 287

Scialoja, Q. II6

Definitions, Q. 268

Seligman, Prof., on Progression, 55, Q. 123

Bibliography, 286

on Neglected English Economists, II9

Senior, Q. II5

Services and Goods, 205

Service Taxes, 28

Shelley, Definition of Justice, Q. I68

Sidgwick, Prof., Q. I30

Definition of Tax, Q. 35, Q.25I

Sismondi, Q. II 2

Definition of Impot, Q. 26I

Six Points of Economy, 2I 4

Slater, Dr., on the Whigs and the Income Tax, Q. 198 
Smith, Adam, Ist Period, Q. 8I 2nd Period, Q. 97 Beaumont and Bielfeld, 88 on Certainty, Q. I 54

Definition of Revenue, Q. 258

"Lectures," 75

Maxims of Taxation: Sources of, 75,88

Maxims unscientific, I 53

T. Rogers on, Q. I60 on "Optional " Taxes, Q. 33

on Productive Expenditure, 20 and Progression, Q. 99

Smith Armitage, Prof., Q. 143

Smith, Sydney, Q. v.

Social Fabric, 228

Growth, 238

Necessity of Taxes, S. Webb on, Preface

"Social Solidarity," I09, I3I

Socialists and Income, 205

Solon, Laws of, Q. 52

Spencer, H., Q. I32

Spending and Taxing, S. Webb on, Preface

Stammhammer, Bibliography, 285

Standard Books, Bibliography, 286

State Property, 235

as sleeping Partner, S. Webb on, Preface

Stein, Q. 132

Steuart, Sir J., Q. 86

his book, 76

Definition of Tax, Q. 250

Steuer, Definitions, Q. 264

Stewart, Q. 108

Stourm, Q. I 33

Definition of Impôt, Q. 263

Summary, 242

TABLE of Diminishing Utility of Income, 188

Table of Taxes and Revenue, 21

Tacitus, Q. 54

Task, Definition of, Q. 249

Task and Tax, 12

Tax, Taxation, Definitions, Q. 248 $32-36,43,242$, et seq.

Definition Related to Principles, 248 et. seq., I70, I75

Definition, First Correct, I5o

Definition, see also Taxes and Taxation

Essential Elements of, I2

Tax and Price, 243

Definitions, 43

with Justice and Economy, 175
Tax Systems and Economic Theory 203

Tax and Task, I2

Tax Terms, Conrad's Classification, Q. 265

De Parieu's Classification, $Q$. 262

Taxation, Autocracy and Democracy, 2I I

and Citizenship, 207, Preface

Definitions, 43, 248 et seq., Q. $32-36$

Principles of, Classified, 220

and the Distribution of Wealth, I 82

Ephemeral, 238

and Equal Incomes 209

Principles in two Groups, I6I

Principles, List of, I5I, 153

Principles and Expediencies, 213

Progressive, Ancient, 54

and Revenue, $\mathbf{I}$

for Revenue only, 183

Taxer (Fr.), 3 I

Taxes, Definition, 29, 43, 32-36, 248 et seq.

Direct and Indirect, Prof. Bastable on, 202

Direct and Indirect, Prof. Bullock on, 202

and Economists, Preface

Effects of, I85

and Family Budgets, 270

as a necessary Evil, S. Webb

on, Preface

as a necessary Evil, 124

Negative, 27

Paid by Persons, 13

or Profits, 236

on Property 206

Pure and Mixed, 7

and Prices, Diagram, 4I

and Rates, 23

and Revenue, 4,5

and Revenue Table, $2 \mathbf{I}$

by Service, 28

Taxing and Spending, Preface

Taussig, Q. I 48

Tea Duty, 274

Terms in Economics, 9

List of, 247

(Tax) Conrad's Classification, Q. 265

Thiers, Q. I2I

Progressive Taxes, $Q .121,123$

" Times," Index, 290

Torrens, Q. 116 


\section{INDEX}

Tributes, 6, 7, 8, 13, 14

"Tribute" and "Tax," 49

Tributa, Definition, Q. 267

Tributo, Definition, Q. 268

Trosne, Le, Definition of Impôt, Q. 260

Tassa, Definition, Q. 268, Q. 269,

Turgot, Q. 82

UsE of Terms in Economics, 9

Utility, Public, I67

Diminishing, 187

Diminishing, and Income, Diagram, 188

VASISHTHA, Q. 50

Vassal and Overlord, Analogy of, 172

Vauban, Q. 68

Vayer, La Mothe de, Q. 6I

Verri, Q. 92

on Economy, 75

Verri, Definition of Tributo, Q. 268

Voltaire, Editors of, Q. 87

WaDE, Calculations of Taxes, 273

Wagner, Q. I3I

Bibliography, 287

Definition of Stewer, Q. 265

Walker, Q. I 35

Divisions of Public Revenue, 3 on Profits, 15

Walras, Q. 122

Wealth, Distribution of, and Taxation, 181,182
Wealth, Distribution of, and Taxation, J. Mill, Prof. Cannan and Prof. Marshall on, Q. I8I

"Wealth of Nations," Q. 97

Webb, S., on Communal and Individual Spending, Preface on the State as Sleeping Partner, Preface

on Taxes and Economists, Preface

on Taxes, Q. 124

on Taxes as a Necessary Evil, Preface

on Taxes as a Social Necessity, Preface

on Taxing and Spending, Preface

Webster, Definition of Fee, Q. 257 Definition of Tax, Q. 249

Wells, D. A., Q. 136 Definition of Tax, Q. 252

"What to Read," Bibliography, 288

Whigs, Dr. Slater on, Q. 198

Wicksteed, P., Q. I 40 Definition of Taxation, Q. 255 on Economy, Q. 178

Xenophon (Pseudo), Q. 53

Young, A., Q. 94

on Commodity Taxes, 76

on Multiplicity, I I9

Zedler, Definition of Steuer, Q. 265 


\section{LIST OF "STUDIES IN ECONOMICS \& POLITICAL SCIENCE."}

A Series of Monographs by Lecturers and Students connected with the London School of Economics and Political Science.

EDITED BY THE

DIRECTOR OF THE LONDON SCHOOL OF ECONOMICS AND POLITICAL SCIENCE.

1. The History of Local Rates in England. The substance of five lectures given at the School in November and December, I895. By Edwin Cannan, M.A., LL.D., I896; new edition, I9I2; xv. and 215 pp., Crown 8vo, cloth. $3 s .6 d$. net.

$$
\text { P. S. King \& Son. }
$$

2. Select Documents Illustrating the History of Trade Unionism. I.-The Tailoring Trade. By F. W. Galton. With a Preface by Sidney WebB, LL.B. I896; 242 pp., Crown 8vo, cloth. 5s.

P. S. King \& Son.

3. German Social Democracy. Six lectures delivered at the School in February and March, I896. By the Hon. BERTRAND Russell, B.A., late Fellow of Trinity College, Cambridge. With an Appendix on Social Democracy and the Woman Question in Germany. By Alys Russell, B.A. I896 ; 204 pp., Crown 8vo, cloth. $3 s .6 d$.

P. S. King \& Son.

4. The Referendum in Switzerland. By M. Simon Deploige, University of Louvain. With a Letter on the Referendum in Belgium by M. J. VAN DEN Heuvel, Professor of International Law in the University of Louvain. Translated by C. P. TREvelyan, M.A., Trinity College, Cambridge, and edited with Notes, Introduction, Bibliography, and Appendices, by LILIAN Toms (Mrs. Knowles), of Girton College, Cambridge, Research Student at the School. I898; x. and 334 pp., Crown 8vo, cloth. $7 s .6 d$. P. S. King \& Son.

5. The Economic Policy of Colbert. By A. J. SARgent, M.A., Senior Hulme Exhibitioner, Brasenose College, Oxford; and Whately Prizeman, I897, Trinity College, Dublin, I899; viii. and 138 pp., Crown 8vo, cloth. 2s. 6d. P. S. King \& Son.

6. Local Variations in Wages. (The Adam Smith Prize, Cambridge University, I898.) By F. W. LAWrence, M.A., Fellow of Trinity College, Cambridge. I899; viii. and 90 pp., with Index and 18 Maps and Diagrams. Quarto, II in. by $8 \frac{1}{2}$ in., cloth. 8s. $6 d$. 
7. The Receipt Roll of the Exchequer or Michaelmas Term of the Thirty-flrst Year of Henry II (1185). A unique fragment transcribed and edited by the Class in Palæography and Diplomatic, under the supervision of the Lecturer, HUBERT HALL, F.S.A., of H.M. Public Record Office. With thirty-one Facsimile Plates in Collotype and Parallel readings from the con-

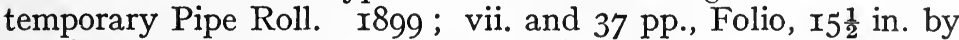
II $\frac{1}{2}$ in., in green cloth; 3 Copies left. Apply to the Director of the London School of Economics.

8. Elements of Statisties. By Arthur L. Bowley, M.A., F.S.S., Cobden and Adam Smith Prizeman, Cambridge; Guy Silver Medallist of the Royal Statistical Society; Newmarch Lecturer, I897-98. 50 pp., Demy 8vo, cloth, 40 Diagrams. I90I ; Third edition, I907; vii. and $366 \mathrm{pp}$. IOs. $6 d$. net.

$$
\text { P. S. King \& Son. }
$$

9. The Place of Compensation in Temperance Reform. By C. P. SANGer, M.A., late Fellow of Trinity College, Cambridge, Barrister-at-Law. I90I ; viii. and I36 pp., Crown 8vo, cloth. 2s. $6 d$. net.

P. S. King \& Son.

10. A History of Factory Legislation. By B. L. Hutchins and A. HARrison (Mrs. Spencer), B.A., D.Sc. (Econ.), London. With a Preface by Sidney WebB, LL.B. I903; new and revised edition, I9II ; xvi. and 298 pp., Demy 8vo, cloth. 6s. net. P. S. King \& Son.

11. The Pipe Roll of the Exchequer of the See of Winchester for the Fourth Year of the Episcopate of Peter Des Roches (1207). Transcribed and edited from the original Roll in the possession of the Ecclesiastical lCommissioners by the Class in Palæography and Diplomatic, under the supervision of the Lecturer, HUBERT Hall, F.S.A., of H.M. Public Record Office. With a Frontispiece giving a Facsimile of the Roll. I903 ; xlviii. and Ioo pp., Folio, I3 $\frac{1}{2}$ in. by $8 \frac{1}{2}$ in., green cloth. I5s. net

P. S. King \& Son.

12. Self-Government in Canada and How it was Achieved : The Story of Lord Durham's Report. By F. Bradshaw, B.A., D.Sc. (Econ.), London; Senior Hulme Exhibitioner, Brasenose College, Oxford. I903; 4I4 pp., Demy 8vo, cloth. 3s. 6 d. net. P. S. King \& Son.

13. History of the Commercial and Financial Relations Between England and Ireland from the Period of the Restoration. By Alice Effie MurRay (Mrs. Radice), D.Sc. (Econ.), former Student at Girton College, Cambridge; Research Student of the London School of Economics and Political Science. I903; 486 pp., Demy 8vo, cloth. 3s. 6d. net. P. S. King \& Son. 


\section{LIST OF "STUDIES IN}

\section{ECONOMICS \& POLITICAL SCIENCE."}

A Series of Monographs by Lecturers and Students connected with the London School of Economics and Political Science.

\section{EDITED BY THE}

DIRECTOR OF THE LONDON SCHOOL OF ECONOMICS AND POLITICAL SCIENCE.

1. The History of Local Rates in England. The substance of five lectures given at the School in November and December, I895. By EdWin Cannan, M.A., LL.D., I896; new edition, I9I2; Xv. and 2 I5 pp., Crown 8vo, cloth. 3s. $6 d$. net.

$$
\text { P. S. King \& Son. }
$$

2. Select Documents Illustrating the History of Trade Unionism. I.-The Tailoring Trade. By F. W. Galton. With a Preface by Sidney WebB, LL.B. I896; 242 pp., Crown 8vo, cloth. $5 s$. P. S. King \& Son.

3. German Social Democracy. Six lectures delivered at the School in February and March, I896. By the Hon. BERTRAND Russell, B.A., late Fellow of Trinity College, Cambridge. With an Appendix on Social Democracy and the Woman Question in Germany. By Alys Russell, B.A. I896 ; 204 pp., Crown 8vo, cloth. $3 s .6 d$.

P. S. King \& Son.

4. The Referendum in Switzerland. By M. Simon Deploige, University of Louvain. With a Letter on the Referendum in Belgium by M. J. van DEN Heuvel, Professor of International Law in the University of Louvain. Translated by C. P. TREvelyan, M.A., Trinity College, Cambridge, and edited with Notes, Introduction, Bibliography, and Appendices, by LILIAN Tomn (Mrs. Knowles), of Girton College, Cambridge, Research Student at the School. I898; x. and 334 pp., Crown 8vo, cloth. 7s. $6 d$. P. S. King \& Son.

5. The Economic Policy of Colbert. By A. J. Sargent, M.A., Senior Hulme Exhibitioner, Brasenose College, Oxford; and Whately Prizeman, I897, Trinity College, Dublin, I899; viii. and 138 pp., Crown 8vo, cloth. 2s. 6d. P. S. King E् Son.

6. Local Variations in Wages. (The Adam Smith Prize, Cambridge University, I898.) By F. W. LAwrence, M.A., Fellow of Trinity College, Cambridge. I899; viii. and 90 pp., with Index and 18 Maps and Diagrams. Quarto, II in. by $8 \frac{1}{2}$ in., cloth. $8 s$. $6 d$. 
7. The Receipt Roll of the Exchequer or Michaelmas Term of the Thirty-first Year of Henry II (1185). A unique fragment transcribed and edited by the Class in Palæography and Diplomatic, under the supervision of the Lecturer, HuBERT HALL, F.S.A., of H.M. Public Record Office. With thirty-one Facsimile Plates in Collotype and Parallel readings from the contemporary Pipe Roll. I899; vii. and 37 pp., Folio, I5 $\frac{1}{2}$ in. by II $\frac{1}{2}$ in., in green cloth; 3 Copies left. Apply to the Director of the London School of Economics.

8. Elements of Statistics. By Arthur L. Bowley, M.A., F.S.S., Cobden and Adam Smith Prizeman, Cambridge; Guy Silver Medallist of the Royal Statistical Society; Newmarch Lecturer, I897-98. 50 pp., Demy 8vo, cloth, 40 Diagrams. I90I ; Third edition, I907; vii. and $366 \mathrm{pp}$. Ios. $6 d$. net.

$$
\text { P. S. King \& Son. }
$$

9. The Place of Compensation in Temperance Reform. By C. P. SANGer, M.A., late Fellow of Trinity College, Cambridge, Barrister-at-Law. I90I ; viii. and I36 pp., Crown 8vo, cloth. 2s. $6 d$. net.

P. S. King \& Son.

10. A History of Factory Legislation. By B. L. Hutchins and A. HARrison (Mrs. Spencer), B.A., D.Sc. (Econ.), London. With a Preface by Sidney WebB, LL.B. I903; new and revised edition, I9II ; xvi. and 298 pp., Demy 8vo, cloth. $6 s$. net. P. S. King \& Son.

11. The Pipe Roll of the Exchequer of the See of Winchester for the Fourth Year of the Episcopate of Peter Des Roches (1207). Transcribed and edited from the original Roll in the possession of the Ecclesiastical iCommissioners by the Class in Palæography and Diplomatic, under the supervision of the Lecturer, HUBERT Hall, F.S.A., of H.M. Public Record Office. With a Frontispiece giving a Facsimile of the Roll. I903 ; xlviii. and roo pp., Folio, I3 $\frac{1}{2}$ in. by $8 \frac{1}{2}$ in., green cloth. I5s. net

$$
\text { P. S. King \& Son. }
$$

12. Self-Government in Canada and How it was Achieved : The Story of Lord Durham's Report. By F. BRADSHAw, B.A., D.Sc. (Econ.), London; Senior Hulme Exhibitioner, Brasenose College, Oxford. I903; 4I4 pp., Demy 8vo, cloth. 3s. 6d. net.

$$
\text { P. S. King \& Son. }
$$

13. History of the Commercial and Financial Relations Between England and Ireland from the Period of the Restoration. By Alice Effie Murray (Mrs. Radice), D.Sc. (Econ.), former Student at Girton College, Cambridge; Research Student of the London School of Economics and Political Science. I903; 486 pp., Demy 8vo, cloth. 3s. 6d. net. P. S. King \& Son. 
14. The English Peasantry and the Enclosure of Common Fields. By Gilbert Slater, M.A., St. John's College, Cambridge ; D.Sc. (Econ.), London. I906 ; 337 pp., Demy 8vo, cloth. Ios. 6d. net.

Constable of $\mathrm{Co}$.

15. A History of the English Agricultural Labourer. By Dr. W. HAsBach, Professor of Economics in the University of Kiel. Translated from the Second Edition (I908) by Ruth Kenyon. Introduction by SIDNEY. WEBB, LL.B. I908; xvi. and 470 pp., Demy 8vo, cloth. $7 s .6 d$. net.

P. S. King \& Son.

16. A Colonial Autocracy : New South Wales under Governor Macquarie, 1810-1821. By Marion Phillips, B.A., Melbourne, D.Sc. (Econ.), London. I909; xxiii. and 336 pp., Demy 8vo, cloth. Ios $6 d$. net.

P. S. King \& Son.

17. India and the Tariff Problem. By H. B. Lees Smith, M.A., M.P. Igog; I20 pp., Crown 8vo, cloth. 3s. $6 d$. net.

Constable \& Co.

18. Practical Notes on the Management of Elections. Three Lectures delivered at the School in November, I909, by ElLIS T. Powell, LL.B. B.Sc. (Econ.), Fellow of the Royal Historical and Royal Economic Societies, of the Inner Temple, Barristerat-law. Igog; 52 pp., 8vo, paper. Is. 6 d. net.

$$
\text { P. S. King \& Son. }
$$

19. The Political Development of Japan. By G. E. UYEharA, B.A., Washington, D.Sc. (Econ.), London. xxiv. and 296 pp., Demy 8vo, cloth. Igro. Ss. 6d. net. Constable \& Co.

20. National and Local Finance. By J. WATSON Grice, D.Sc., (Econ.), London. Preface by Sidney Webb, LL.B. I9ro ; 428 pp., Demy 8vo, cloth. Ios. $6 d$. net.

$$
\text { P. S. King \& Son. }
$$

21. An Example of Communal Currency. Facts about the Guernsey Market-house. By J. THEODORE HARRIs, B.A., with an Introduction by Sidney Webb, LL.B. IgII ; xiv. and 62 pp., Crown 8vo, cloth. Is. $6 d$. net; paper, Is. net.

P. S. King \& Son.

22. Municipal Origins. History of Private Bill Legislation. By F. H. SPENCER, LL.B., D.Sc. (Econ.), London; with a preface by Sir Edward Clarke, K.C. I9II; xi. and 333 pp., Demy 8vo, cloth. Ios. $6 d$. net. Constable \& $\mathrm{Co}$.

23. Seasonal Trades. By VARIous Authors. With an Introduction by Sidney Webb. Edited by SidNey WeBb, LL.B., and Arnold Freeman, M.A. IgI2; xi. and 4 Io pp., Demy 8vo, cloth. $7 s .6 d$. net.

Constable \& $\mathrm{Co}$. 
24. Grants in Aid. A Criticism and a Proposal. By Sidney WeBb, LL.B. I9II ; vii. and I35 pp., Demy 8vo, cloth. 5s. net. Longmans, Green \& Co.

25. The Panama Canal : A Study in International Law. By H. ARIAS, B.A., LL.D. IgII ; xiv. and I88 pp., 2 maps, bibliography, Demy 8vo, cloth. Ios $6 d$. net. P. S. King \& Son.

26. Combination Among Railway Companies. By W. A. RoberTson, B.A. I9I2 ; I05 pp., Demy 8vo, cloth. Is. $6 d$. net ; paper, Is, net.

Constable \& Co.

27. War and the Private Citizen. Studies in International Law. By A. Pearce Higgins, M.A., LL.D. ; with Introductory Note by the Rt. Hon. Arthur Cohen, K.C. I9I2 ; xvi., 200 pp., Demy 8vo, cloth. 5s. net. P. S. King \& Son.

28. Life in an English Village : an Economic and Historical Survey of the Parish of Corsley, in Wiltshire. By M. F. Davies. I909; xiii., 3 I9 pp., illustrations, bibliography, Demy 8vo, cloth. Ios. $6 d$. net. T. Fisher Unwin.

29. English Apprenticeship and Child Labour : a History. By O. Jocelyn Dunlop, D.Sc. (Econ.), London; with a Supplementary Section on the Modern Problem of Juvenile Labour, by the Author and R. D. Denman, M.P. I9I2 ; pp. 390, bibliography, Demy 8vo, cloth. Ios. $6 d$. net.

T. Fisher Unwin.

30. Origin of Property. By J. St. Lewinski, D.Ec.Sc., Brussels. I9I3; xi. and 7 I pp., Demy 8vo, cloth. 3s. $6 d$. net.

Constable \& Co.

31. The Modern Tendency towards Industrial Combination in some Spheres of British Industry. By. G. R. CARTER, M.A. In the Press.

32. Tariffs at Work : an Outline of Practical Tariff Administration. By Jorn Hedley Higginson, B.Sc. (Econ.), Mitchell Student of the University of London; Cobden Prizeman and Silver Medallist. I9I3; I50 pp., Crown 8vo, cloth. 2s. net.

$$
\text { P. S. King \& Son. }
$$

33. English Taxation : 1640-1799 : an Essay on Policy and Opinion. By William Kennedy, M.A., Shaw Research Student at the London School of Economics and Political Science. I9I3; 200 pp., Demy 8vo, cloth. 7s. $6 d$. net.

G. Bell \& Sons.

34. Emigration from the United Kingdom to North America, 1763-1912. By Stanley C. Johnson, M.A., Cambridge. I9I3； xvi. and 387 pp., Demy 8 vo, cloth. 6 s. net.

G. Routledge \& Sons. 
35. The Financing of the Hundred Years' War. By Schuyler B. Terry. I9I3; xv. and I99 pp., Demy 8vo, cloth, 6s. net. Constable \& Co.

36. Kinship and Social Organisation. By W. H. R. RIvers, M.A., F.R.S., Fellow of St. John's College, Cambridge.

In the Press.

37. Nature and First Principle of Taxation. By ROBERT Jones, B.Sc. (Econ.). Demy 8vo, cloth. 7s. 6d. net.

$$
\text { P. S. King \& Son. }
$$

Series of Bibliographies by Students of the School.

1. A Bibliography of Unemployment and the Unemployed. By F. IsABEL TAYlor, B.Sc. (Econ.), London. Preface by Sidney Webb, LL.B. I909; xix., 7I pp., Demy 8vo, cloth. 2s. net; paper, Is. $6 d$. net. P. S. King \& Son.

2. Two Select Bibliographies of Mediæval Historical Study. By Margaret F. Moore, M.A. ; with Preface and Appendix, by Hubert Hall, F.S.A. I9I2; I85 pp., Demy 8vo, cloth. 5s. net.

Constable \& Co.

3. Bibliography of Roads. By Dorothy Ballen : an enlarged and revised edition of a similar work compiled by Mr. and Mrs. Sidney Webb in I906. Demy 8vo, cloth. I5s. net.

P. S. King \& Son.

4. A Select Bibliography for the Study, Sources, and Literature of English Mediæval Economic History. Edited by HUBERT Hall, F.S.A. Demy 8vo, cloth. 5s. net.

$$
\text { P. S. King \& Co. In the Press. }
$$

Series of Geographical Studies.

1. The Reigate Sheet of the One-inch Ordnance Survey. A Study in the Geography of the Surrey Hills. By ElLEN Smitr. Introduction by H. J. Mackinder, M.A., M.P. I9Io ; xix., IIo pp., 6 Maps, 23 Illustrations. Crown 8vo, cloth. 5s. net.

A. \&. C. Black.

2. The Highlands of South-West Surrey: A Geographical Study in Sand and Clay. By E. C. Matrhews. IgII ; viii. and I24 pp., 7 Maps, 8 Illustrations, 8vo, cloth. 5s. net.

A. \& C. Black.

Series of Contour Maps of Critical Areas.

1. The Hudson-Mohawk Gap. Prepared by the Diagram Company from a map by B. B. Dickinson. Igr3: I sheet I8 in. by $22 \frac{1}{2}$ in. Scale, 20 miles to $I$ inch. $6 d$. net, post free folded $7 d$. , rolled $g d$. Sitton, Praed \& Co. 


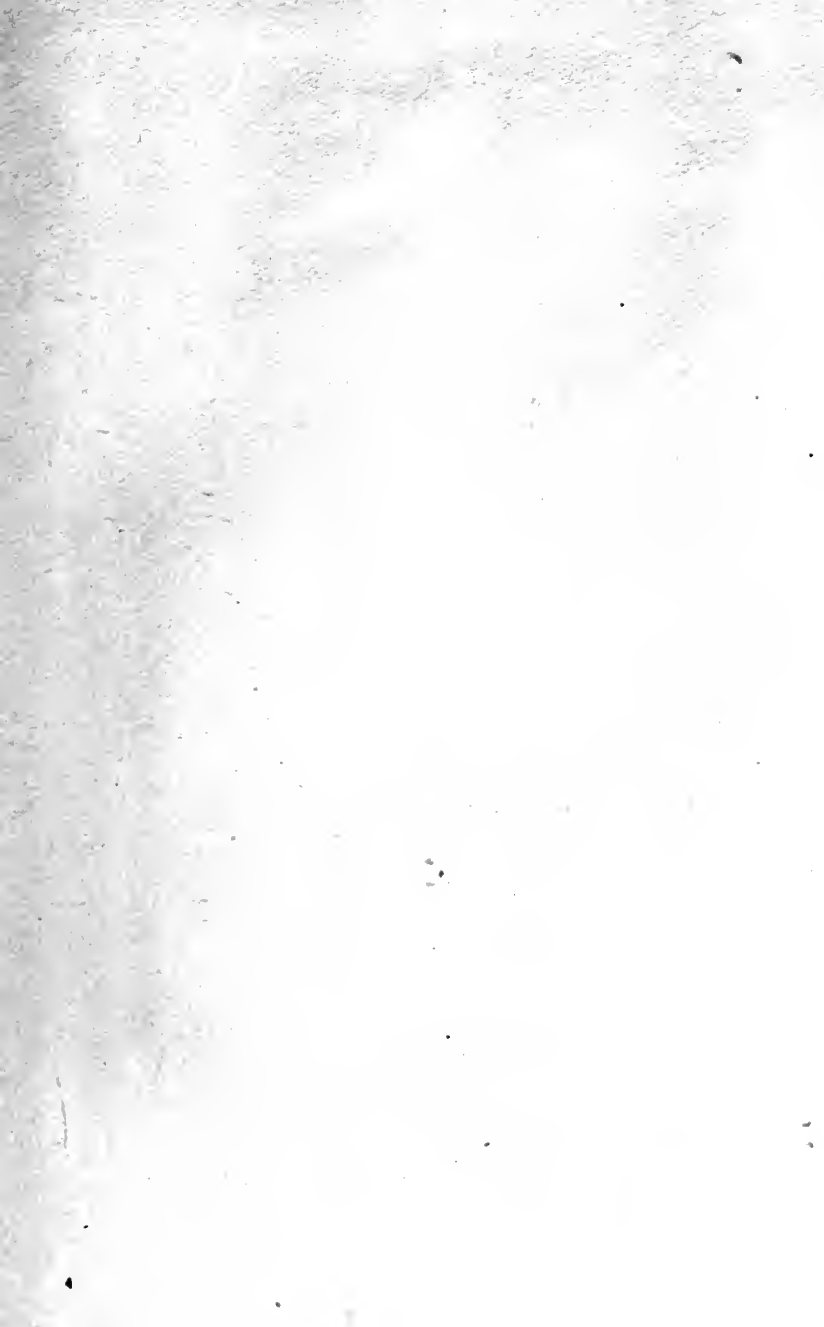




\section{DAY USE \\ RETURN TO DESK FROM WHICH BORROWED

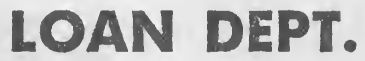

This book is due on the last date stamped below, or on the date to which renewed.

Renewed books are subject to immediate recall.

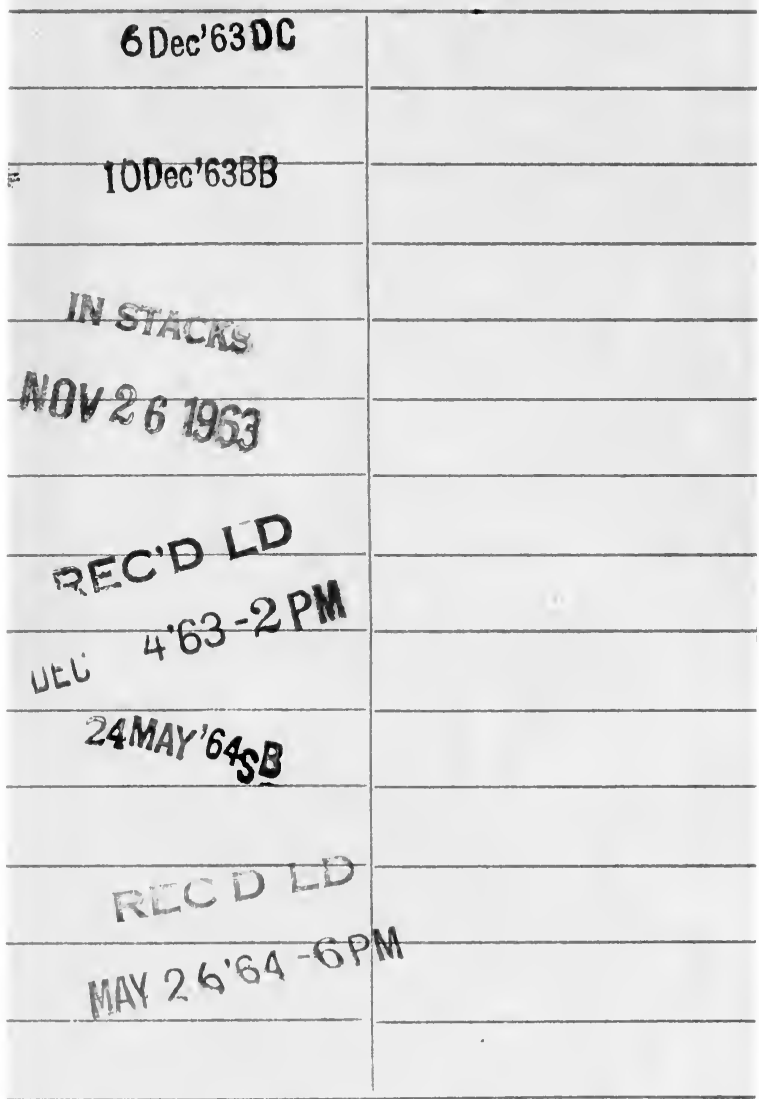

LD $21 \mathrm{~A}-40 m-4,{ }^{\prime} 63$

(D $6471 \mathrm{~s} 10) 476 \mathrm{~B}$
General Library

University of California

Berkeley 

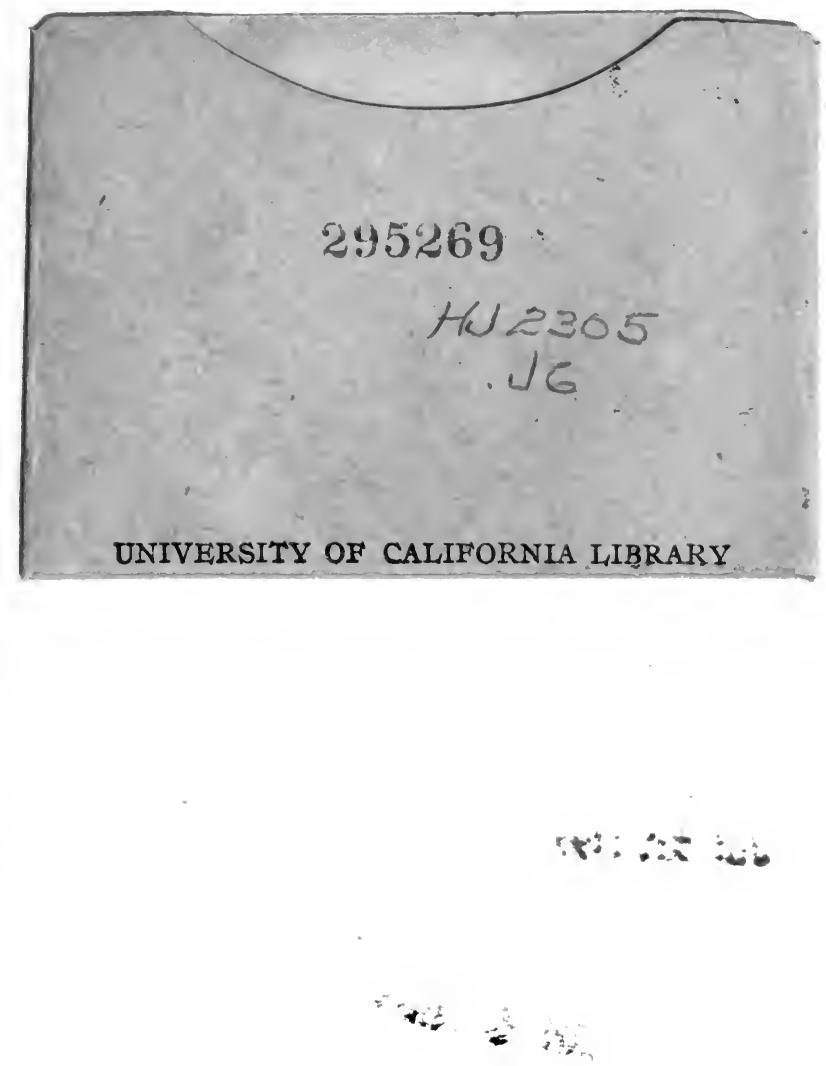

